Universidade de Brasília - UnB

Instituto de Ciências Sociais - ICS

Centro de Pesquisa e Pós-Graduação sobre as Américas - CEPPAC

Programa de Pós-Graduação em Estudos Comparados sobre as Américas PPG/CEPPAC

Por Nações Afirmativas: O Estado Plurinacional na Constituição Boliviana de 2009 e o papel da Confederación de Pueblos Indígenas de Bolívia (CIDOB)

Juliana Pinheiro Nogueira Bessa 
Por Nações Afirmativas: O Estado Plurinacional na Constituição Boliviana de 2009 e o papel da Confederación de Pueblos Indígenas de Bolívia (CIDOB)

Dissertação apresentada ao Programa de PósGraduação em Estudos Comparados sobre as Américas (PPG/CEPPAC) como parte dos requisitos para obtenção do grau de mestre em Ciências Sociais, especialista em Estudos Comparados sobre as Américas.

Juliana Pinheiro Nogueira Bessa

Autora

Dr. Cristhian Teófilo da Silva Orientador

Brasília, D.F. 
Por Nações Afirmativas: O Estado Plurinacional na Constituição Boliviana de 2009 e o papel da Confederación de Pueblos Indígenas de Bolívia (CIDOB).

Autora: Juliana Pinheiro Nogueira Bessa

Dissertação apresentada ao Centro de Pesquisa e Pós-graduação sobre as Américas CEPPAC da Universidade de Brasília como parte dos requisitos para obtenção do grau de mestre.

Brasília, abril de 2015.

Data da aprovação:

Prof. Dr. Cristhian Teófilo da Silva

Orientador

Membro da Banca

Membro da Banca

Membro da Banca 
BESSA, Juliana Pinheiro Nogueira.

Por Nações Afirmativas: O Estado Plurinacional na Constituição Boliviana de 2009 e o papel da Confederación de Pueblos Indígenas de Bolívia (CIDOB)/Juliana Pinheiro Nogueira Bessa Brasília, 2015 - $195 \mathrm{f}$.

Dissertação apresentada para obtenção de grau de mestre Universidade

de Brasília. Centro de Pesquisa e Pós-graduação sobre as Américas - CEPPAC.

Orientador: Cristhian Teófilo da Silva.

1. Movimento Indígena 2. Autonomia Indígena 3. Estado Plurinacional 4..América Latina 5. Bolívia 6. Pensamento crítico 
¿Cómo puede uno evitar hundirse en ciénaga del sentido común si no es convirtiéndose en extranjero de su próprio país, lengua, sexo e identidad?

Julia Kristeva $^{1}$

\footnotetext{
${ }^{1}$ KRISTEVA, Julia. "A New Type of Intellectual: The Dissident," in The Kristeva Reader, Edited by Toril
} Moi, New York: Columbia University Press, 1986 
À memória do meu avô, Miguel Tomaz de Bessa, exemplo de um sertão forte e delicado. 


\section{Agradecimentos}

Gostaria de iniciar agradecendo aos meus pais, Cândido e Ana, por terem me apoiado nesta empreitada e por terem me ajudado a superar as minhas dificuldades mais profundas. É também a eles que dedico este trabalho e o meu amor.

Em segundo lugar, agradeço à Universidade de Brasília - UnB e ao Centro de Pesquisa e Pós-Graduação sobre as Américas - CEPPAC, por fazerem parte dos longos anos da minha formação e principalmente por terem possibilitado essa pesquisa e o meu encontro com a Bolívia.

O término desse trabalho eu devo ao Professor Crishtian Teófilo, a quem serei eternamente grata pela extrema generosidade e sensibilidade. Toda a minha admiração, e o meu muito obrigada a você, Cristhian, de coração.

Estendo meus agradecimentos a todos os professores do CEPPAC, especialmente à Simone Rodrigues e ao Jacques que estiveram presentes em momentos importantes durante o meu mestrado. E claro, também agradeço aos servidores do CEPPAC e envio um especial e carinhoso agradecimento a Jacinta por seu trabalho diligente junto ao programa.

Meu obrigada também ao Professor Salvador Schavelzon, docente da USP, bolivianista de forte sensibilidade, sempre aberto ao diálogo e grande articulador de pesquisadores bolivianista. Lamento, por outro lado, não ter aproveitado tudo que Schavelzon poderia me oferecer enquanto grande fonte de pesquisa.

Àqueles que encontrei em campo e que foram intermediários da ponte BolíviaBrasil meus sinceros agradecimentos a todo o diretório da CIDOB, ao pessoal do CEJIS, à Sarela Paz, a Ana Janaína, a equipe da OEA, à Katyussa, ao Alejandro e El Marsh.

Aos latino americanistas, bolivianistas e e demais exploradores de nuestra querida América, meus agradecimentos à: Renata Albuquerque, Ana Maria, Wildes, Tamara (e demais membros do LAEPI), Maurício H., Valeria Coronel, Álvaro, Pedro Brandão, João Telésforo, Katynka.

Aos amigos que fiz no CEPPAC, que me inspiraram e estão no meu coração: Leonardo, Aldo, Rafinha, Ivanise, Clarissa e Thiago, Aline, Estevão, Vogly, Nelson, Hans, Mara, Elizabeth. Aos colegas que fiz no DAN envio um abraço de agradecimento ao querido Pedro Macdowell, à Carol Pedreira, ao Walisson, ao Pedro Pires, ao T. Aragão e ao Rogério.

Aos amigos que estiveram presentes, que acompanharam pacientemente, que nunca deixaram de acreditar, que colaboraram de alguma forma com esse trabalho e que me ajudaram em momentos difíceis: André Melo (obrigada por tudo), Izadora, Isabele, Carlos Henrique, Eudora, Caio, Rafael e Bruna, Aline A., Elias, Mayra, Professor Peters, Eduardo (pela paciência amorosa), Xaman, Marcella, Gabriel Semerene, Olívia, Victor, Carol Amorim, Rafael Were, Thamires, Raul e João Vargas. Aos meus amigos que me ajudaram em silêncio, Professor Berti, Rubens-Refazenda, Lene e Luciano, obrigada.

Aos que foram essenciais a minha saúde física e mental e me conduziram no processo de pesquisa e escrita como sendo um desafio também de autoconhecimento e amor, a minha eterna gratidão à Monja Magda, ao Mestre Tokuda, ao Maestro Andino Lucidor Flores, da Nação Pachamama - Mística Andina. Sem me esquecer, claro, da Adriana e do estimado Túlio Americano por terem cuidado tão de perto do meu corpo, mente e coração. 


\section{Resumo}

Desde os anos 90 do século XX, o movimento indígena do oriente boliviano, representado pela Confederación de Pueblos Indígenas del Oriente Boliviano - CIDOB, tem lutado pela garantia dos seus direitos sobre suas terras e territórios. Em 2002 os indígenas do oriente cruzaram o país em sua quarta marcha, uma de suas reivindicações era então uma Assembleia Constituinte originária. Fazendo parte do Pacto de Unidade colaboraram na escrita do projeto do texto que orientaria parte do texto final da Nova Constituição Política do Estado (CPE). Até 2009, momento em que a constituição foi referendada pelos bolivianos, os indígenas das terras baixas seguiam próximos ao governo de Evo Morales. Enquanto muitos celebravam o primeiro marco de "criação" do novo Estado Plurinacional da Bolívia, a CIDOB sabia que conquistas posteriores, como o marco regulatório de autonomias de 2010, seriam tão importantes quanto a CPE. Com o mesmo espírito de luta contínua, a questão da consulta prévia e do atropelo das políticas de desenvolvimento é colocada em debate, e em 2012, David Críspin afirma: "sem autonomias, não há Estado Plurinacional". Para Luís Tapia a Marcha em defesa do TIPNIS poderia ser encarada como segundo marco para um "Estado Plurinacional". É fato que a autonomia sempre esteve presente na defesa por um Estado Plurinacional e aparece nas propostas logo anteriores a ACN. A partir da perspectiva dos indígenas das terras baixas essa dissertação visa compreender a luta por autonomias e a sua conexão com a demanda de uma Constituição para um Estado Plurinacional de modo a acessarmos os sentidos êmicos de "plurinacionalidade" na Bolívia. A partir dos intelectuais orgânicos e do debate que ocorre diante dos eventos recentes se fará uma revisão bibliográfica, colocando a estratégia da CIDOB - e a sua particularidade regionais e étnicas como estudo de caso.

Palavras-chaves: Movimento Indígena, CIDOB, Bolívia, Autonomia, Plurinacionalidade 


\section{Abstract}

The indigenous movement of lowland Bolivia has fought for the guarantee of their rights over their lands and territories, that movement is represented by the Confederación de Pueblos Indígenas del Oriente Boliviano - CIDOB, since the 90s of the XXth century. In 2002 the indigenous peoples from the east crossed over the country in its fourth manifestation march, one of their claim was then a Originary Constituent Assembly. Part of the Pacto de Unidad, CIDOB collaborated in the writing of the text design that would guide part of the final text of the New Political Constitution of the State (CPE). By 2009, time the constitution was ratified by Bolivians, indigenous lowland still followed near the Evo Morales government. While part of the Bolivian people celebrated the first landmark of "creation" of the new Plurinational State of Bolivia, CIDOB knew that later achievements, such as the 2012 Infra Law on Indigenous Autonomy, would be as important as the CPE. In the spirit of continuous fighting, the issue of previous consultation and the hustle of development policies is placed in debate, and in 2012, David Crispin says: "no Indigenous Autonomy, no Plurinational State". In turn, Luis Tapia considered the campaign for the defense of the TIPNIS territory the second landmark for a "Plurinational State". It is a fact that for Amazonic peoples the autonomy issue has always been present in the defense for a Plurinational State and it appears in the earlier proposals of CIDOB to ACN. From the perspective of indigenous movements of lowland Bolivia this Master's thesis aims to understand the struggle for autonomy and its connection with the demand for a Constitution towards a Plurinational State. In this sense, it presents emic senses of "plurinationality" in Bolivia. This work will be a literature review after the contribuition of organic intellectuals and the recents debates in Bolivia, having the strategy of CIDOB - and its regional and ethnic particularity as a case study.

Key-words: Indigenous Movement, CIDOB, Bolivia, Autonomy, Plurinationality 


\section{Sumário}

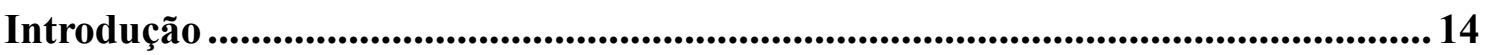

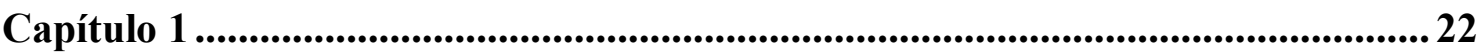

1.1.1. Os vários povos americanos de diferentes nações - um continente populoso e

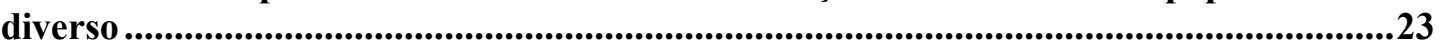

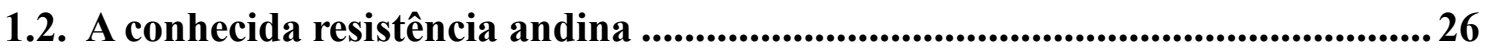

1.2.1. Guerra e os heróis da resistência indígena no período colonial, Tupac Amaru .....26

1.2.2. O herói boliviano e suas particularidades, Tupac Katari.......................................227

1.2.3. A proletarização dos andinos na colônia ....................................................................29

1.3. República, a emergência da cidadania e dos direitos a todos os nacionais. $O$ pensamento de esquerda, a sindicalização e a Revolução de 52 ............................. 31

1.3.1. O MNR e a Revolução de 1952 ..........................................................................34

1.3.1. Movimento Katarista, CONAMAQ, COB, CSUTCB e MAS ....................................38

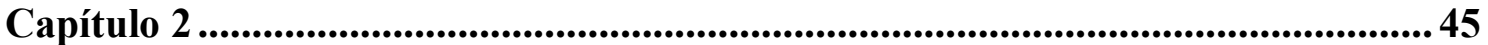

2.1. O contato tardio e a relação dos indígenas das terras baixas com as Missões

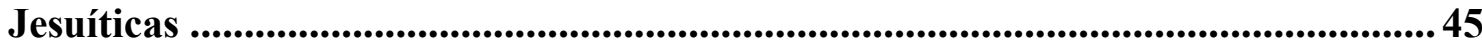

2.2. A adaptação, a resistência e a negociação para entrar nas Missões.................. 47

2.3. O contexto da articulação dos povos indígenas frente ao Estado .....................53

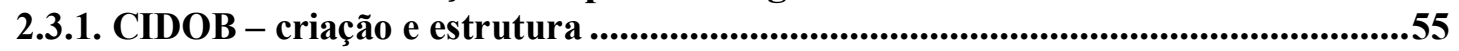

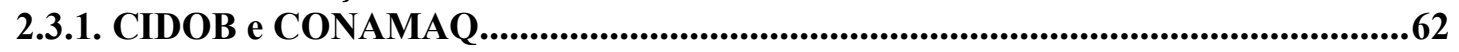

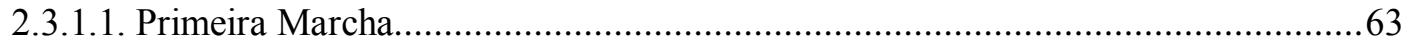

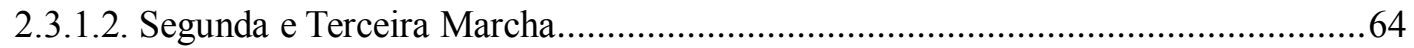

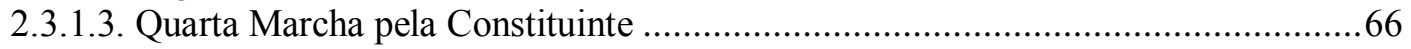

2.4. CIDOB e o Pacto de Unidad ...................................................................................... 67

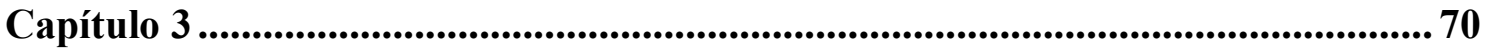

3.1. Rumo a Assembleia, um longo caminho de 2002 a 2006 .................................... 70

3.1.1. Evo é eleito com a promessa de convocar a Assembleia ...............................................72

3.1.2. Regras do Debate - uma questão de maiorias e de constituinte derivativa ou

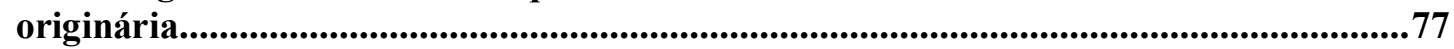

3.2. Propostas à AC - a proposta da CIDOB e a proposta consensuada do Pacto de

Unidad.........................................................................................................8 80

3.2.1. Ordenamento territorial e a questão da autonomia nas propostas do CIDOB e do

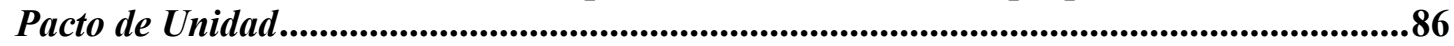

3.2.2. Plurinacionalidade e as organizações indígenas ...................................................8

3.3. A constituinte se inicia em Sucre ........................................................................8 89

3.3.1. Os posicionamentos do movimento indígena frente à $\mathrm{AC}$.........................................90

3.3.2. As organizações do lado de fora da AC.........................................................................93

3.3.3. Ações do governo Evo Morales para a região Amazônica......................................97

3.3.3. Comissão "Visión de País"...............................................................................98

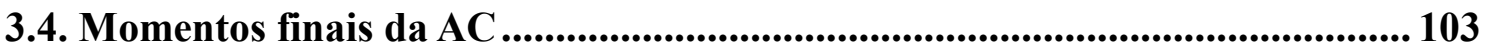

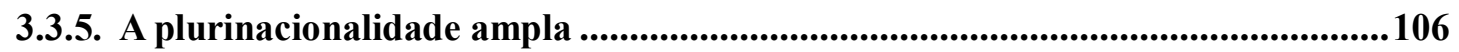

3.4.1. Referendo Dirimidor ......................................................................................................107

3.4.2. Constituiçãa aprovada ...............................................................................................109

3.4.3. Lutas para assegurar direitos conquistados na nova Constituição ......................... 110

3.4.3.1. A Lei Marco de Autonomia e Descentralização.................................................... 113 
3.4.3.2. Consultas livres, prévias e informadas .

Conclusão ................................................................................................................................... 118

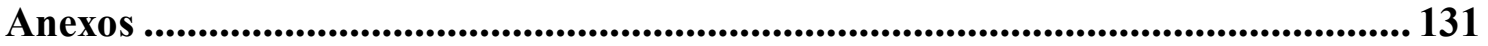

Bibliografia ............................................................................................................... 187 


\section{Glossário}

ABT - Autoridade de Bosques e Tierras

AC - Asamblea Constituyente ${ }^{2}$

AOCI - Alianza Obrera Campesina Indígena

APG - Asamblea del Pueblo Guarani

BOCINAB - Bloque de Organizaciones Campesinas e Indígenas del Norte Amazónico

CEDIB - Centro de Documentación e Información Bolivia

CEJIS - Centro de Estudios Jurídicos e Investigación Social

CENDA - Centro de Comunicación y Desarrolo Andino

CIDOB - Confederación de Pueblos de Indígenas del Oriente Boliviano

CIPCA - Centro de Investigación y Promoción del Campesinado

CIRABO - Central Indígena de la Región Amazónica de Bolívia

CPE - Constitución Política del Estado

CPEM-B - Central de Pueblos Etnicos Mojeños del Beni

COB - Central Obrera Boliviana

COICA - Coordinadora de Organizaciones Indígenas de la Cuenca Amazónica

CONAMAQ - Consejo Nacional de Ayllus y Markas del Qullasuyu

COPNAG - Central de Organización del Pueblo Nativo Guarayo

CPESC - Coordinadora de Pueblos Etnicos de Santa Cruz

CRSUCIR - Central Regional Sindical única de Campesinos Indígenas de Ragaypampa

CSUTCB - Confederación Unica de Trabajadores Campesinos de Bolivia

CSUTCOA - Central Sindicar única de Trabajadores Campesinos Originarios de

Ayopaya

CSCB - Confederación Sindical de Colonizadores de Bolívia

FNMC-BS - Federación Nacional de Mujeres Campesinas Bartolina Sisa

GANPI - Gran Asamblea Nacional de los Pueblos Indígenas

INRA - Instituto Nacional de Reforma Agraria

LECAC - Ley Especial de Convocatória a la Asamblea Constituyente

LMAD - Lei Marco de Autonomia e Descentralização

MAS - Movimiento al Socialismo

\footnotetext{
${ }^{2}$ A Asamblea Constituyente também foi amplamente chamada de "Asamblea Constituyente Nacional" ACN. Considerando as disputas por uma Assembleia Constituinte Originária e uma Assembleia Constituinte Derivativa, o nacional aqui poderia se contrapor semânticamente à plurinacionalidade. Assim, uso AC como assim fazem as organizações indígenas, e também autores como Salvador Schavelzon.
} 
MITKA - Movimento Indianista Tupac Katari, partido radical que tem como princípio a volta das formas de produção comunal.

MRTK/MRTKL - Movimento Revolucionário Tupac Katari, partido derivado do Movimento Katarista, com mais representates no congresso é um partido mais aberto a alianças, diferentemente do MITKA.

MNR - Movimiento Nacionalista Revolucionário

MST-B - Movimiento Sin Tierra de Bolivia

$\mathrm{OICH}$ - Organización Indígena Chiquitana

OIT - Organização Internacional do Trabalho

PODEMOS - Poder Democrático Social, partido considerado base opositora do governo Evo.

TCO - Tierra Comunitacia de Origen

TIPNIS - Territorio Indígena e Parque Nacional Isiboro-Sécure

UN - Frente de la Unidad Nacional, partido considerado conservador criado em 2003

USAID - Agência Estadunidense para o desenvolvimento internacional 


\section{Introdução}

“[...] Poblamos esta sagrada Madre Tierra com rostros diferentes, y comprendimos desde entonces la pluralidad vigente de todas las cosas y nuestra diversidad como seres y culturas. Así conformamos nuestros pueblos, y jamás comprendimos el racismo hasta que lo sufrimos desde los funestos tiempos de la colônia. [...]”"

(trecho do preâmbulo da CPE da Bolívia, 2009)

“Artículo 1. Esta Constitución reconoce la preexistencia de las naciones y pueblos indígenas originarios, el dominio ancestral sobre sus territorios y garantiza su libre determinación que se expresa en la voluntad de conformar y ser parte del Estado Unitario Plurinacional, $y$ en el derecho a controlar sus instituciones, al auto gobierno, a desarrollar su derecho y justicia propia, su cultura, formas de vida y reproducción, al derecho a reconstituir sus territorios y al derecho a definir su desarrollo con identidad."

(artigo da proposta da CIDOB para a Nova Constituição Política de Estado, 2006 ${ }^{3}$ )

Entrei no programa de mestrado com um projeto de pesquisa na área de direitos humanos, segurança pública e violência que seria, então, realizado no Brasil. Entretanto, por estar em uma instituição de pesquisa de estudos de área, isso me inclinava às possibilidades de estudar países próximos. Um seminário que ocorreu em 2008 na Universidade de Brasília (UnB), ocasião em que se encontravam o Professor Javier Restrepo e a Professora Catharine Walsh, foi responsável pelo meu interesse em pesquisar a Bolívia. A fala de Walsh sobre o Estado Plurinacional veio ao encontro de uma curiosidade que eu alimentava a respeito do debate "multicultural" nas Ciências Sociais e na teoria política. O interesse por tal debate vinha, por sua vez, de um período de políticas e discussões bastante frutíferas sobre ações afirmativas que aconteciam no Brasil e também no âmbito da UnB. As limitações desse debate pareciam ultrapassadas

\footnotetext{
${ }^{3}$ Versão reduzida da Proposta da CIDOB em Anexo 2 desta publicação.
} 
por esse novo paradigma que me apresentava Walsh e que permitiam problematizar não só o Estado brasileiro, considerando o meu contexto local enquanto estudante, como também as dificuldades enfrentadas no debate e na luta indígena no Brasil ou na América Latina como um todo.

A escolha da Confederación de Pueblos de Indígenas del Oriente Boliviano (CIDOB) para compreender a "plurinacionalidade" (ou o Estado Plurinacional em seu "vir a ser",4) se deu primeiramente pelo fato de terem sido os primeiros a se articularem e demandarem uma Constituinte. E também porque ao discutirem seu próprio projeto de texto constitucional foram aqueles que trouxeram a ideia de plurinacionalidad, juntamente com outros princípios igualmente importantes e esclarecedores sobre o conceito de plurinacionalidade, tais como Autonomia Indigena e Buen Vivir ${ }^{5}$. Ademais, a CIDOB por manter uma relativa independência dos posicionamentos de governo e partido, oferece um contraponto interessante ao ponto de vista institucional, e com isso quero dizer também, um contraponto ao Estado, ao governo do presidente Evo Morales eleito em 2005 e reeleito em 2014 e ao seu partido, o Movimiento al Socialismo (MAS). Também há um contraponto de visões de mundo, entre Amazônia e Andes, não só entre heterogeneidades étnicas, mas entre disparidades de projetos nacionais e projetos comunitários. É necessário ainda dizer que os indígenas das terras baixas no Oriente boliviano tem de um lado o Estado e do outro elites regionais, como atores sociais importantes no jogo político durante a Constituinte.

Este trabalho se concentra no "processo de mudança" que ocorre na Bolívia, alavancada pelas Marchas por Terra e Dignidade em 1990 e pela Guerra da Água em 2000 e a Guerra do Gás em 2002. Tal processo implica em um conjunto de eventos e mudanças impulsionadas por movimentos indígenas e que tem como um dos seus pontos altos a nova Constituição (2009). Nesse período há uma aproximação e articulação de variados movimentos indígenas e populares em torno do Pacto de Unidad, que como o próprio nome diz, conclama uma "unidade" no momento de construir um novo pacto social através da nova Constituição. A direção tomada neste trabalho parte das perspectivas e reivindicações dos movimentos que acionaram tal

\footnotetext{
${ }^{4}$ Vir a ser, ou devir, conceito deleuziano focado no processo, tanto o processo do Ser, quanto o ser enquanto processo, em contraposição a ideia do Ser imóvel estabelece o conceito de mudança como constituinte do real, é o acontecer, o ir sendo, aquilo que se movimenta. (Deleuze, 1992) (ABBAGNANO, 1998:268). O "vir a ser" de um Estado Plurinacional da perspectiva de um movimento indígena organizado e minoritário no contexto boliviana constituirá o objeto de pesquisa principal desta dissertação.

${ }^{5}$ As categorias do discurso dos interlocutores indígenas e bolivianos aparecerão sempre em itálicos.
} 
processo, o seu percurso, os seus anseios e as suas contradições.

A Constituição e a criação de um novo Estado aqui é um evento no tempo dentro da experiência política da organização na qual me concentro: a Confederação Indígena dos Povos do Oriente da Bolívia. A estrutura e as principais estratégias da CIDOB em busca da definição dos seus espaços e da melhor forma de geri-los aparecerá em contraste às posições e perspectivas de outros atores sociais e políticos que fizeram parte do "processo de mudança", principalmente no evento da Assembleia Constituinte.

A partir do momento em que a constituição foi referendada os órgãos oficiais, os jornais e outros meio passaram a referir-se à Bolívia diariamente como o "Estado Plurinacional da Bolívia”. Equador e Bolívia, respectivamente nos anos de 2008 e 2009, mudaram o status de um tradicional conceito moderno: o Estado-Nação.

O que é um Estado Plurinacional no contexto latino-americano? A pergunta surge e não há uma definição delimitada. É fato que o que o vice-presidente boliviano, Álvaro García Linera, julga ser hoje plurinacionalidad, concepção muitas vezes associada a interculturalidad e decolonialidad (Walsh, 2008) é distinto do que pensa o dirigente do movimento indígena do oriente boliviano, mesmo que inicialmente fossem semelhantes. Que acontecimentos experimentados pelo movimento indígena do oriente definem e redefinem o conceito oficial de plurinacionalidade?

Pois um conceito que abarca tantos elementos pode ser caracterizado de forma genérica. Do ponto de vista material a constituição traz avanços claros em temas como ecologia, representação política, direitos culturais, autonomia. Seria esse conjunto de mudanças no âmbito da constituição que definiria o Estado agora como plurinacional? Que conjunto de mudanças são essas? Elas conseguiriam transformar a modernidade, o seu excesso de razão, consumo e individualismo? Quais são os desafios de implementálas sob esse novo paradigma tão radical?

Quais são os princípios do Estado Plurinacional? O que significaria descolonizar o Estado ou ter a Pachamama em seu preâmbulo? Uma nova forma de fazer política emerge como necessidade. Por sua vez, como o Estado mesmo mediará essas mudanças? Seria demasiado ousado tentar com esse trabalho responder a essas questões. A partir da perspectiva de uma organização indígena que representa a região das Terras Baixas a nível nacional o que se buscará será oferecer um contraponto real para entender as questões e limites que surgem desse novo projeto de sociedade e/ou de sociedades.

Para fins de análise, o trabalho adotará o termo "plurinacionalidade", em vez de 
Estado Plurinacional, considerando assim "plurinacionalidade" o projeto político ${ }^{6}$ promovido por movimentos sociais e indígenas, projeto este que não necessariamente encontra uma conclusão após a aprovação da Nova Constituição. Ainda assim, da mesma forma que o trabalho apresenta a relação dos movimentos com o Estado, o termo plurinacionalidade aparecerá por vezes de mãos dadas a ideia de Estado Plurinacional já que ambos projetos políticos se assistem mutuamente. Diferente dos trabalhos que buscam após a aprovação da Constituição compreender as mudanças realizadas no bojo do Estado, este trabalho se posiciona no olhar dos movimentos frente ao Estado, as lacunas e os anseios ainda não alcançados do movimento indígena considerando o projeto político da plurinacionalidade e o que ela inclui, como o avanço do tema das autonomias indígenas.

Nos últimos anos é notável o maior número de pesquisas realizadas na Bolívia a partir do Brasil no CEPPAC temos o trabalho de Camargo (2014) sobre as políticas de descolonização do Estado Plurinacional da Bolívia, o de Amorim (2014) sobre a discursividade indígena no âmbito legislativo, o de Moraes (2014) sobre o caso TIPNIS e o trabalho de Andrade (2014) sobre uma identidade que se projeta nacionalmente a partir da história de um massacre, São também várias as análises sobre o governo de Evo, sobre os movimentos camponeses, os movimentos indígenas, sobre o texto constitucional, sobre novas formas de fazer política ou sobre autonomia, e também sobre eventos tais quais, guerra da água, campanha do TIPNIS, Assembleia Constituinte. Pesquisas ainda tem sido realizadas sobre as várias políticas colocadas em prática para dar cabo a algum dos princípios ou direitos materiais garantidos na constituição. Cada uma dessas pesquisas é realizada em diferentes áreas do conhecimento, privilegiando o aspecto jurídico, político-institucional, ou dos movimentos sociais. É louvável que a academia tenha dado a atenção devida à experiência que ocorre nesse país, pois vive-se aí uma produção muito original e paradigmática para a produção acadêmica na região.

Mesmo tendo partido da pergunta "O que significa plurinacionalidade para a CIDOB?", esta pesquisa não visa ser um construto teórico-filosófico, buscando uma bibliografia que dê conta dos conceitos aqui levantados. Os conceitos e as experiências

\footnotetext{
${ }^{6}$ Mónica Chuji Gualinga, intelectual equatoriana trabalha com o termo "plurinacionalidade" e o define como "projeto político" acionado por movimentos sociais (2008). Por sua vez esses movimentos sociais não são apenas de classe, mas também étnicos, de gênero e ambientais - com a complexidade e a sobreposição que tais identidades se apresentam na realidade social. Disponível em: http://alainet.org/active/23366\&lang=es, acessado em 20/02/2015.
} 
de plurinacionalidade e autonomia indígena são bastante recentes e diversas. Assim, o trabalho acompanha a trajetória do movimento indígena até chegar a atuação do movimento indígena das terras baixas bolivianas, atravessada pelo evento da Assembleia Constituinte e pela refundação de um Estado, resta apontar contradições e questões em aberto tanto para os movimentos quanto para o Estado. A pesquisa tem como objetivo dialogar e organizar o debate e o pensamento crítico produzido atualmente sobre o tema. Serão encontradas aqui poucas afirmações conclusivas e mais questões em aberto, uma vez que se está abordando processos em curso.

As Ciências Sociais produzidas na América Latina e na Bolívia têm se comprometido com o pensamento crítico, a partir de produções mais colaborativas de intelectuais orgânicos que refletem e fazem política. Um paradigma que busca descolonizar-se e produzir conhecimento de si e para si. As páginas seguintes não oferecem a originalidade que esses intelectuais orgânicos podem oferecer, mas tem como fim organizar eventos tão próximos e por vezes tão distantes à um público brasileiro. Ou aos que pretendem se tornar bolivianistas e procuram uma leitura inicial.

O trabalho está dividido em três capítulos. O primeiro oferece um histórico sobre que nações seriam essas a que o termo plurinacional se refere e retoma. Tais nações, povos ou grupos serão apresentados pela sua contínua articulação e resistência. O primeiro capítulo apresenta a história de lutas dos indígenas na Bolívia, que permeia o imaginário indianista no país, principalmente nos Andes. É a constante luta do movimento indígena que ajudará a compreender a fundo $\mathrm{o}$ significado de plurinacionalidade, as contradições presentes no Estado e a diversidade de formas de fazer política. O segundo capítulo adentra o caso específico dos povos amazônicos e apresentará o objeto dessa pesquisa - a CIDOB, a sua estrutura organizacional, suas demandas e estratégias. O foco recai sobre a mais grandiosa dentre as suas estratégias políticas: as marchas nacionais, que antecedem a Assembleia Constituinte. O terceiro capítulo apresenta a revisão bibliográfica para compreender a CIDOB e suas demandas em um recorte de tempo específico: a Assembleia Constituinte, a sua atuação dentro e fora da Assembleia. Para isso são analisadas tanto pesquisas e publicações relacionadas ao tema como também o material publicado pela própria CIDOB. É também necessário lançar o olhar para além e ao redor da constituinte, pois considerando os entraves da Assembleia, há nela limitações ou vazios - como cita Salvador Schavelzon (2013:465), que apontarão questões em aberto na definição do Estado Plurinacional, segundo os anseios dos movimentos indígenas. $\mathrm{O}$ terceiro capítulo também se volta para os debates 
acerca da Bolívia, do Estado Plurinacional e da Autonomia Indígena por parte dos movimentos contemporâneos. A impossibilidade de delimitar conceitos como Autonomia e Plurinacionalidade e sim falar dos avanços e questões demonstram que trata-se portanto de um projeto político em construção e talvez um novo paradigma de pensamento em marcha. Autores clássicos ajudarão a compreender que Estado-nação é esse que será refundado segundo uma perspectiva descolonizadora, pluralizante e intercultural. Mas de que forma a identidade nacional será a partir de agora articulada e negociada, para socorrer a discussão clássica do Estado-Nação, alguns bolivianistas aparecerão para apontar contradições e lançar questões sobre o desafio de tornar-se um Estado Plurinacional.

A pesquisa e o seu texto foram iniciados em 2009 e desde o ano passado foi retomado. Inicialmente, trabalhei com a perspectiva do "reconhecimento do direito" - o problema levantado referia-se ao reconhecimento do movimento pelo Estado e como esse reconhecimento se traduzia em direitos. Em um segundo momento, me distanciei da perspectiva da antropologia jurídica, que embasava aquela problematização, após questionar-me em campo sobre a dimensão política e as relações de poder assimétricas que eram evidentes nas demandas levantadas pela CIDOB. A ideia de luta por reconhecimento (ver Honneth, 2003) pareceu-me mais apropriada para aproximar-me do movimento indígena e entender sua estratégia.

Uma pesquisa tradicional de campo, com informantes e tempo hábil para convívio e entrevistas qualitativas com a CIDOB não foi realizada. Estive em Santa Cruz na sede da CIDOB em janeiro de 2009, a menos de um mês do referendo que aprovaria a nova Constituição. Na primeira semana conversei com o presidente da CIDOB Adolfo. As entrevistas não seguiram sistematicamente junto a CIDOB, pois iniciei o trabalho como observadora internacional na missão da OEA para o referendo dirimidor constitucional. Este trabalho por sua vez consistia em acompanhar a visão de diferentes organizações sociais sobre o processo final da nova Constituição ${ }^{7}$. Durante a missão a equipe viajou pelo departamento de Santa Cruz, acompanhando municípios e regiões mais populosas e politicamente mais tensas. Ao fim e ao cabo da missão retorno da última reunião da OEA em La Paz para Santa Cruz. Enquanto o governo prepara o evento/ritual que celebraria a a nova Constituição e a refundação do Estado $^{8}$, tento

\footnotetext{
${ }^{7}$ As organizações mais relacionadas a esse processo final seriam as que mais participaram nas campanhas pelo "Sí" e pelo "No" a nova Constituição.

${ }^{8}$ A celebração acontece em El Alto, município conurbado a La Paz e também conhecido por sua
} 
retomar contato com o diretório da CIDOB que a partir daquele momento estavam concentrados nos encontros prévios à Grande Assembleia Nacional de Povos Indígenas - GANPI. Parecia um momento político de sintetizar os acontecimentos recentes para atualizar suas demandas e seguir lutando. Neste momento colhi materiais de organizações adjacentes à CIDOB, como a CIPCA e a CEJIS. Era um momento de síntese, em que jornais, rádios e a população estavam aplicadas em refletir sobre o significado da constituinte e do novo texto constitucional. Durantes esses anos que me separam da viagem à Bolívia em 2009, acompanho o material e as notícias que são vinculadas na rede. Há muito material bruto, como vídeos no youtube, programas de rádioweb, blogs e sites de notícias da própria organização a serem sistematizados e analisados. Enquanto as mídias alternativas se articulam e circulam uma grande quantidade de comunicação, na grande mídia essa comunicação segue invisível e no debate nacional e nas manchetes a atenção é dada ao conflito e a polarização, que nesse período correspondia às mudanças a serem realizadas no âmbito do Estado e a resistência conservadora de quem o compunha e hoje ainda o compõe. O discurso de legitimação e deslegitimação focados no poder central parece necessário a esses meios. E terão base de apoio não só nos setores conservadores bolivianos, mas também em mídias e setores conservadores de outros países e fazem parte de disputas políticas, que passam, mas também transcendem as simples disputas partidárias. Com isso dito, busco chamar atenção para um conflito sobreposto à relação do Estado com as organizações indígenas tidas como mais radicais e/ou organizações indígenas das Terras Baixas, mesmo que não apareçam salientadas devem ser tomadas em conta.

Relatos de colegas que estiveram na região ou que fizeram contato direto também serviram à organização de minha análise do processo em curso. Entretanto me valho da possibilidade de fazer uma revisão bibliográfica do assunto, com a síntese de material veiculado, principalmente escrito como material principal de pesquisa. Também a partir de um quebra cabeça histórico tento compreender a região como expressão da dualidade co-existente entre as Terras Altas e as Terras Baixas, que parte da complexidade populacional de um vasto continente, tal como sinalizam Mann (2007) e Fausto (2000). Para completar este cotejamento, como Cusicanqui aponta (1984), há um material latente para refletir o Estado e as instituições com os pensamentos e

articulação política e social. Na ocasião Evo Morales, após a constituinte e o referendo, em um ato de devolução dá posse as autoridades indígenas e campesinas, Um ato simbólico de refundação do Estado e do poder. 
ideologias de esquerda a partir de como os indígenas dos Andes entraram na política absorvendo as práticas e o discurso crítico do marxismo, quais contradições e autocríticas seriam possíveis de se fazer a partir daí etc.

De certo modo distante do contexto de transformações sociais, culturais e políticas do mundo andino, as Ciências Sociais (desde clássicos como Lewis Henry Morgan, Karl Marx e Friedrich Engels, Émile Durkheim e Marcel Mauss etc., até autores mais recentes como Richard Adams, Julian Steward, Eric Wolf, Clifford Geertz, Ernst Gellner, Anthony Giddens, Jürgen Habermas, para mencionar alguns) debruçaram-se sobre o conceito e a realidade do Estado-Nação como projeto de construção de uma comunidade maior unificada e articulada em suas várias expressões de diferenças. Este debate, no entanto, se deu em um quadro epistemológico muitas vezes alheio aos processos independentistas e de construção nacional da América Latina (à exceção de Steward e Wolf, por exemplo) ou ao próprio pensamento social e político latino-americano. Benedict Anderson, neste sentido, foi um dos autores preocupados em reverter esta situação de negligência intelectual (2011). As Ciências Sociais feitas no Brasil, muitas vezes se dedicam a revisar e dialogar com as teorias e análises produzidas a partir da Europa e dos Estados Unidos e, mesmo Benedict Anderson busca repensar o pioneirismo crioulo dos processos de construção nacional latino-americanos a partir de um olhar orientalista. Desse modo, essa dissertação visa contribuir para a formação de uma perspectiva situada a partir do Brasil para pensar os processos e formas dos Estados nacionais e plurinacionais latino-americanos a partir de contribuições téoricas advindas, sobretudo, da própria região. 


\section{Capítulo 1}

\subsection{A história da resistência indígena como marco para o Estado Plurinacional}

Este capítulo retoma brevemente a Antiguidade das populações que viviam no hemisfério ocidental antes da conquista e da colonização dessa região com o objetivo de apontar as origens de sua resistência e luta. Agora essa resistência e luta são designadas enquanto lutas de movimentos sociais e indígenas e seguem na conservação das suas coletividades. Este capítulo se debruça nas sequência de resistências indígenas desde o primeiro contato com o colonizador, de forma a apontar a longa duração presente na demanda atual por um novo Estado e na busca por autonomias. Para Braudel é possível inserir um fato, de duração mínima na história em um contexto de duração maior ${ }^{9}$, em sua conjuntura e estrutura. A própria existência de "nacionalismos" ou anseios de autonomia, causando um deslocamento da identidade nacional é prova da pluralidade do tempo social (Braudel, 1969:43). A dialética da duração de Braudel permite perceber o que muda e o que permanece. A relação do histórico de resistências com a construção de um Estado Plurinacional, não é uma análise histórico, mas uma forma de mostrar como os indígenas recuperam hoje esses processos em busca de sedimentar suas lutas.

No caso de um novo Estado, o Estado Plurinacional, o objetivo é perceber as contradições presentes nessas mudanças e permanências, cruzando-as com o percurso e os anseios ancestrais dos movimentos envolvidos. O Estado Plurinacional seria o início de um novo Estado ou a reinstauração reelaborada de um arranjo político anterior? As coisas se iniciam a partir do Estado, agora novo? Que processos e cosmopolíticas definem esse Estado-das-coisas/das gentes?

Antropológos, historiadores, arqueólogos, estudiosos, dentre outros, a exemplo de Fausto e Mann, nos ajudam a reverter a visão de que o continente hoje chamado de americano teria sido povoado por pequenos grupos e sociedades "incivilizadas" e "isoladas", auxiliando-nos a complexificar o passado do continente como uma região populosa, diversa e integrada por múltiplas articulações civilizatórias, intertribais, modos de produção, rotas etc. Este é um passo fundamental para retirar a marginalidade atribuída ao "outro indígena" e para passarmos a encará-los como sociedades de igual

\footnotetext{
${ }^{9}$ Américo Augusto da Costa Souto, em "Fernand Braudel em três Dimensões: dialética da duração, didática e geo-história. www.periodicos.udesc.com.br/indez.php/percursos/article/view/1456
} 
importância e de igual particularidade - algo que contará também com a revisão da história nacional, a emergência de outras histórias e a mudança da forma de se conceber como nação.

A resistência indígena no período da conquista e da colonização demonstram a constante articulação política que se contrapõe à dominação desde tempos imemoriais. Os heróis indígenas da resistência, como veremos, irão sobreviver no imaginário coletivo desses povos e retornarão cosmologicamente para cumprir suas promessas e utopias. As desigualdades, entretanto, persistiram e novas lutas no século XX resgataram o discurso da identidade indígena através do movimento Katarista e da consagração de Tupac Katari como herói. Como espero demonstrar, o Estado Plurinacional não resulta desses processos históricos como expressão de uma tomada "orgásmica" do poder a partir da liderança de um típico "criollo latinoamericano" travestido de índio: “(...) vivo como una ardilla, trepador y latero, y con una vasta experiência de manipulador de hombres y mujeres, adquirida en su larga trayectoria de dirigente cocalero y membro de la aristocracia sindical", como escreveu Mario Vargas Llosa em janeiro de 2006 (apud Landa Vásquez, 2007: 14). A plurinacionalidade na Bolívia não resulta da mera ascenção do sindicalismo cocalero, mas de um processo civilizador, um processo civilizador que como tomado por Elias (1994) na teoria de parsons descreve um sistema totalmente integrado, uma sociedade total, unificada. Esse sistema que também pode ser identificado no que Batalla afirma em "México Profundo" ao tratar da latência desse processo de retomada, da latência ressurgente, que caminha paralela e às margens.

\subsubsection{Os vários povos americanos de diferentes nações - um continente populoso e diverso}

A fábula discursiva que nomeia "descobrimento" o encontro da população branca "europeia com as populações "americanas" é a mesma fábula que transforma a pluralidade de povos em um "outro" genérico: o índio. Fausto (2000) em seu livro "Os índios antes do Brasil" afirma que se convencionou usar "cacicazgo" e, por sua vez "cacique" para autoridades indígenas a partir do reconhecimento dessa organização política da sociedade Taino, localizadas nas Antilhas. Curiosamente a denominação de cacicado e de cacique para organização política e para autoridade indígena se tornou a única a partir do instante em que todos os povos presentes na América foram 
convertidos em uma identidade unificada, o índio. Não por acaso, o termo reaparece em diferentes movimentos indígenas, incluindo o katarista, como um conceito político que retoma o evento e as consequências da colonização. Assim a condição era a mesma para todos, a de povos dominados. Mesmo após a suposta abolição do colonialismo com os movimentos de independência, o indígena e o cacique são denominações genéricas e demonstram a falta de informação das similitudes e diferenças das organizações políticas dos povos indígenas. Fausto (2000) em uma perspectiva não usual descreve as variadas populações que ocupavam parte do continente, não se aprofunda mas apresenta as diferentes ocupações na larga faixa territorial brasileira divididas por diferentes geografias, formas de vida e nível de contatos, bem distribuído por todo o território do que hoje se conhece como Brasil.

Entre outros relatos, constam descrições de grandes cidades, e até da existência de cidades fortificadas em áreas de várzea no que hoje é a região Amazônica. É encontrada com alguma frequência nas crônicas quinhentistas uma paisagem de população adensada ao longo das margens dos rios. Algumas dessas cidades podendo se estender por até 7 kilometros à beira rio, com criação de animais e pequenos cultivos. Complementar a tais relatos, estudos recentes sobre o bioma amazônico apontariam que a paisagem inicial da floresta era bem menos rica. Teriam sido séculos e séculos de ocupação humana a responsável pelo enriquecimento vegetal e alimentar dessa região. O que leva a crer que as populações diferente do que se imagina possuíam um controle sobre a construção da paisagem a sua volta, desmistificando a ideia da floresta como uma natureza intocada. É o que também aponta Mann (2007) ao relatar uma das grandes descobertas para arqueólogos e antropólogos na região amazônica da Bolívia, mais precisamente no que hoje é o departamento de Beni. É apenas na década de 70, com pesquisadores sobrevoando a região que se percebe corredores ecológicos e ilhas ecológicas ainda conservados, com desenhos e caminhos bastante precisos. Tais relatos de ocupação, circulação e de relação com o espaço ainda são parcamente estudados. Para Mann um dos entraves, além do desaparecimento de algumas dessas grandes sociedades seria a dificuldade da arqueologia desbravar terrenos tropicais.

Mann (2007) também apresenta novas estimativas da população do continente nos séculos XV e XVI e fala de cidades com mais de 200 mil habitantes. Havia, possivelmente, uma densidade demográfica muito maior que a considerada convencionalmente, inclusive a ideia de que na região andina a população seria mais densa que na região amazônica também se mostrou ser um senso comum muitas vezes 
não baseado na realidade. Em alguns pontos com uma densidade demográfica tão alta quanto a da Europa na mesma época.

O mito das terras virgens, de terras pouco habitadas ou ainda da paisagem intocada a ser explorada são informações que circularam nas novas nações mestiças latino-americanas sem estudos precisos que a embasassem. O outro que não está pra além de alguma fronteira, que estará dentro das suas próprias fronteiras serão indivíduos carentes de tutela, comparáveis às crianças, o que justificaria ocupar uma terra de ninguém. Ou se justificaria a violência física a partir do discurso do outro-bárbaro, possivelmente uma projeção do próprio homem branco. A partir dos conflitos iniciais desse encontro é possível perceber em cima de que pressupostos projetos políticos tal qual o do Estado é construído, o Estado-Nação projeto político que estabelece fronteiras e homogeneiza culturas, por sua naturez não dará conta de explicar os seus diferentes.

A respeito da região Amazônica, em particular é só no século seguinte ao "descobrimento" que os exploradores ibéricos em maior parte portugueses em território que viria a se tornar brasileiro adentram a região Amazônica. Os relatos, nesse momento são considerados crônicas, há uma desconfiança do seu caráter fabuloso. A razão para isso, seriam os diferentes e contraditórios relatos. No entanto, pesquisadores como Mann não descartam que paisagens e populações descritas desapareceram com uma velocidade impressionante devendo se considerar a possiblidade tanto da violência do contato e do impacto das doenças trazidas por brancos como também razões desconhecidas - mudanças relativas a própria dinâmica desses grupos.

Como aponta Mann, há uma dificuldade de recuperação de informações sobre as populações que desapareceram e cujos vestígios arqueológicos são de difícil identificação. Resta como vestígio maior as mitologias das populações que seguiram existindo. A região Andina é comumente associada ao Império Inca, sabe-se que outros impérios como a de Tihuanaku existiram antes do Incaico e que este não surgiu subitamente, mas foi fruto de um longo processo de conquista e expansão, em que outras sociedades são aglutinadas, como o caso da dominação dos povos Quéchuas sobre os Aymarás e estes que por sua vez resistem. A região andina que está presente na Argentina, Chile, Equador, Bolívia, Peru e chega até a Colômbia era a região por onde expandiu a Civilização Incaica e se encontrava bastante integrada principalmente o que hoje são Peru e Bolívia, mais no centro da sede do império. A região Amazônica do que hoje é a Bolívia, sabe-se tinha contato com os incas, mas suas relações e história de contato faz parte de uma história própria dos indígenas no chaco e Amazônia. 


\subsection{A conhecida resistência andina}

\subsubsection{Guerra e os heróis da resistência indígena no período colonial, Tupac}

\section{Amaru}

Bartolomé de Las Casas em "Brevíssima relação de destruição das Índias” revela a imagem da conquista. Acompanhando conquistadores quinhentistas presenciou violência, bárbare, genocídio, denúncia de uma guerra justificada também através da moral cristã). Com a voz: os indígenas retomam histórias do primeiro contato, a diplomacia parece ser algo natural à grande parte das culturas. De forma diplomática promoviam a troca, recebiam os estrangeiros em sua comunidade e com o tempo passaram a definir um limite de tempo em que os exploradores poderiam ficar ali, relatos de maior espírito contam sobre indígenas colocando os conquistadores para seguir viagem enquanto riam e mostravam as nádegas. Sobre o recorrente contato com tais viajantes, um Iroquês (Mann, 2007) conclui: "lá onde vivem não deve estar bom para terem chegado até aqui". Em outro relato quinhentista ouvem-se as vozes indígenas: "os deuses deles devem comer ouro", tamanha a obsessão dos conquistadores em achar veios do metal nos territórios indígenas. Mann acredita que não só os indígenas do nordeste da América do Norte viveram momentos de diplomacia com os conquistadores, mas também - apesar dos relatos de violência, é possível que tenha existido muitas semelhanças os primeiros contatos no mundo incaico. De todo modo, a colonização das terras americanas torna-se bem sucedida a partir de genocídios promovidos a partir do rearranjo de alianças e inimizades intertribais conjungada a epidemias e transformações socioeconômicas.

Neste tipo de cenário, Manco Inca último imperador Inca liderou uma rebelião que cercou a cidade de Cuzco em 1559 - na ocasião tomada pelos espanhóis. Tupac Amaru seu filho, por sua vez, se tornou um herói dos Andes ao resistir em Vilcabamba cidade escolhida para ser a nova sede do império após a tomada de Cuzco. Em 1570, Francisco de Toledo - vice-rei do Peru declarou guerra e Tupac Amaru foi morto no mesmo ano, com ele parte dos seus descendentes também foi morta ou exilada. No entanto, alguns de seus descendentes retornam. Fruto do casamento da nobreza Inca remanescente com nobres espanhóis, o Marqués de Oropesa reclama seu título de Tupac Amaru II e realiza "a grande rebelião" no Peru. Mestiço com educação europeia, mas 
também em contato com os grandes sábios da nobreza de Cuzco, a grande rebelião se iniciou com o sequestro de um corregedor e reclamou não só a independência do poder colonial - o que seria a primeira independência verdadeiramente anticolonialista, mas a abolição da mita e outras formas de exploração indígena, assim como declarou pela primeira vez na América a abolição da escravidão negra. $\mathrm{O}$ que se segue à supressão da grande rebelião é a abolição dos cargos de autoridade ocupados por lideranças indígenas, e maior opressão por parte do poder colonial.

\subsubsection{O herói boliviano e suas particularidades, Tupac Katari}

Enquanto isso, no mesmo período, na Bolívia, Tupac Katari, um órfão, analfabeto que trabalhou em minas faz um levante em 1781, seu nome é a junção de Tomás Katari, cacique, líder da resistência em Chayanta e Tupac Amaru II. Diferentemente do líder no país vizinho, Tupac Katari não possui ascendência nobre. A linha de sucessão presente em Tupac Amaru II evoca uma autoridade ancestral, que por sua vez legitima o direito do seu povo a um governo próprio. $\mathrm{O}$ que acontece com Katari é a evocação da marca de uma tradição de heróis indígenas na luta contra a dominação. A sua autoridade enquanto líder se respalda no seu poder de articulação territorial (Camargo, 2006:75) - além do anseio coletivo do rompimento de uma condição. O levante liderado por Katari é uma expressão maior de inúmeras outras desobediências à legislação colonial e tentativas de conjuração, que até então tinham tido abrangência local. Duraram quatro décadas e seu ápice foi o cerco à La Paz por 109 dias ${ }^{10}$ - o longo período de resistência e conflito - maior que as duas guerras mundiais europeias juntas, revela uma constante oposição à ordem colonial - não se constituindo como episódios isolados (Stern, 1987). Albó (2002:107) chama atenção para a unidade desse movimento, no qual dentro dele conviviam barreiras linguísticas e de jurisdições dos vicerreinados. Katari mostrou não ser um herói solitário, também Bartolina, sua mulher, tem papel fundamental na rebelião, o que tornará seu nome uma bandeira de protagonismo feminino no mundo indígena. No momento da sua trágica execução, Katari profetiza: "eu morrerei, mas voltarei e serei milhões".

Katari reuniu o apoio de um grande número de caciques e se tornou símbolo da resistência à opressão colonial. A liderança do seu contemporâneo, Tupac Amaru II, o

\footnotetext{
${ }^{10} \mathrm{O}$ cerco a La Paz em 1780 contou com 40 mil homens fechando os caminhos de acesso ao vale paceño. Muitos na cidade morreram de forme, outros afogados - após a destruíção de um dique construído para essa finalidade. Katari não saiu, finalmente vitorioso, pois não possuia armamento e findou diante das tropas de Buenos Aires e Lima.
} 
qual the inspira se apoia no poder advindo da sua ascendência nobre, assim como nos casos de Tupac Amaru I, no período da conquista. O levante reuniu três irmãos Katari na região de Chayanta (Potosí) e sitiou a cidade de La Paz por vários meses. E mesmo depois de sua captura e assassinato, ainda houve focos de resistência. O levante foi uma tentativa de retomada de uma ordem social e política usurpada. Ainda com reminiscências de uma utopia de liberação inspirada em um messianismo incaico. Porém mais do que retomar a ordem perdida, e além de carregar o sentido de nativismo aimará depois a ele associado, a luta de Katari era também contra os abusos de poder da Coroa Espanhola. Uma tentativa de invalidar toda a estrutura colonial. Stern (1987: 35) afirma que o evento se coloca como forte advertência para que as autoridades coloniais assumam medidas conciliatórias a fim de evitar explosões sociais de revolta semelhantes. Enquanto que para os indígenas o cerco simbolizava sua força autóctone e seu poder de articulação territorial, para os hispânicos era uma prova da sua inferioridade numérica, e do medo do "selvagem" presente no habitual "índio" cotidiano (Camargo, 2006: 75). O clima ao final dos cercos era de tentativa de maior controle social, inclusive com extinção da hierarquia do cacique. A memória das violências de ambos os lados, a contínua separação, discriminação que se segue na república só perpetua essa relação de medo e incompreensão.

As quatro décadas (1742-1782) de sublevações andinas já no final do período colonial têm seu ápice com o cerco a La Paz, o primeiro cerco durou 109 dias, com milhares de homens fechando os caminhos de acesso do vale paceño. Construiu-se um dique que depois foi destruído e afogou parte da população. Muitos da cidade sitiada morreram de fome, no entanto não foi possível se apoderar da cidade por falta de armamento adequado. E depois do envio de tropas vindas de Lima e Buenos Aires 40 mil homens caem sobre o poder espanhol (Mesa, 2008). Tal evento demonstra a dimensão do poder de mobilização da população indígena na Bolívia colonial e, ainda, a influência que esse evento marca na memória dos movimentos sociais que atualmente usam a mesma estratégia de mobilização e pressão política, com interdição de vias, estabelecendo "estados de sítio".

O levante conduzido por Katari é uma expressão maior de inúmeras outras desobediências à legislação colonial e tentativas de conjuração que, até então, tinham abrangência local. (Camargo, 2006:112). Tais episódios revelam um contexto de 
permanente oposição à ordem colonial não sendo episódios isolados ${ }^{11}$ (Stern, 1987).

\subsubsection{A proletarização dos andinos na colônia}

Contra que condições os andinos de diversos rincones - articulados por Katari, lutavam? Em 1545 são encontradas minas de prata em Potosí, sua exploração era realizada a partir do trabalho obrigatório indígena - a mita. O regime de trabalho é de 6 dias por semana dentro das minas, condições aberrantes de trabalho e grande quantidade de mortes. Os responsáveis pelo pagamento do Mitayo são os caciques. Figura essa que funciona como representante político e conexão e articulação com o mundo branco, e que na posição de líder situa-se numa situação ambígua, na busca de legitimidade pelos brancos e ao mesmo tempo representante da exploração branca no seio da comunidade. Sob este regime, no século XVII, Potosí se tornou a cidade mais populosa do continente americano e uma das maiores do mundo, com mais de 160.000 habitantes. A economia girava em torno das mais que insalubres condições de trabalho. Crespo (2008) estima mais de 20 mil mortes (La "mita” de Potosí, 2008).

Esta situação histórica resulta das Reformas de Toledo (1568-1581) que conseguiram de maneira eficiente a apropriação sistemática de mão-de-obra indígena, como parte principal de um plano mercantilista e colonial espanhol. Toledo realizou um censo e um "estudo" dos grupos indígenas para melhor realizar a imposição tributária que varia de acordo com o grupo, quantidade, qualidade dos produtos de cada comunidade. No período de Toledo o espaço físico original da comunidade é atropelado pelas leis que instituem a encomienda e reducciones. As reducciones reuniam em uma só unidade comunidades pré-hispânicas dispersas, com a concentração de 15 comunidades em uma, como é o caso de Jesus de Machaca, é facilitado o controle de impostos, pressupostário e facilitava a cristianização. Ao passo que as encomendas asseguravam o provimento contíntio de escravos indígenas capturados para os espanhóis a quem serviam em "troca" da sua cristianização.

Ainda assim há formas de resistências, seja no sincretismo religioso, práticas religiosas e culturais camufladas. Assim como na organização dos ayllus que não desapareceram totalmente. As reducciones eram muitas vezes organizadas pelos ayllus de origem dos seus membros. Assim, quando as reducciones decaem há uma migração

\footnotetext{
${ }^{11}$ Stern, Steve J. Resistance, Rebellion and Consciousness in the Andean Peasant World, 18thto 20th Centuries, University of Wisconsin, 1987.
} 
de volta para as áreas rurais, reorganizando-se de acordo com essa referência dos ayllus remanescentes nas reducciones. Nas cidades também se preservaram espaços de resistência. Ali havia uma divisão explícita, e uma proximidade funcional, os bairros índios ficam próximos aos dos brancos já que trabalham para eles. O curioso é que nessa época esses bairros usufruíam de maior autonomia do que futuramente viriam a ter no período liberal da república. Nesses bairros se contava com um alcalde e leis próprias - mais adequado aos usos e costumes. Os espanhóis estavam terminantemente proibidos de habitar ou permanecer mais que 24 horas num bairro indígena e dentro dele se falava a língua da etnia que ali habitava.

De todo modo, pode-se reconhecer nas reformas de Toledo o início do processo de proletarização dos indígenas, forçando-o a entrar no sistema de atividades econômicas exploratórias, como mineração a fim de conseguir pagar o tributo individual imposto pelos colonizadores espanhóis. A proletarização era o vínculo dessas pessoas com a situação de exploração, afirmação essa que faz com que as ideias marxistas sejam tão bem recebidas e tão facilmente adaptáveis à situação de exploração colonial. Há então uma conexão posterior à situação de pobreza, de continuidade da exploração com a história das identidades, com a história do confronto interétnico. O sentido de trabalho remunerado para pagar impostos, sustentando o Estado que os explora continua mesmo depois do fim da colônia. Com o tempo, além do esvaziamento de sentido junto a sua relação com o trabalho, os indígenas vão perdendo também o espaço de convívio da comunidade. $\mathrm{O}$ espaço que continha significado e guardava sua memória, também espaço concreto em que materializa e que se exprime a lembrança é a cada dia usurpado, reduzido ou ressignificado. Como ocorreu mesmo durante a reforma agrária em que as terras foram realocadas de maneira individualizada e sem alternativa de serem comunitárias, levando a uma outra relação com o espaço e com a comunidade, e finalmente promovendo o faccionalismo e o acamponesamento dos indígenas.

O processo de transformação das organizações sociais indígenas pré-existentes a partir da servidão indígena sucedida pelas políticas de acamponesamento das populações já profundamente transformadas pela exploração colonial, passou a sustentar sócio-economicamente toda a base do que viria a ser o Estado boliviano moderno. É pelo trabalho de $78 \%$ da população, indígena, que o abastecimento de alimentos e tecidos acontece em todo o país, sem falar das formas de trabalho obrigatório que sustentavam um Estado que seguia oprimindo-os. Instituições de exploração que representam um trabalho sem um sentido existencial ou comunitário e com elementos 
de controle social.

\subsection{República, a emergência da cidadania e dos direitos a todos os nacionais. $O$ pensamento de esquerda, a sindicalização e a Revolução de 52}

No país independente, moderno, os índios não trabalhariam sem o pago de um salário. E os tributos abusivos, em teoria, teriam fim. A modernidade nacionalizadora deveria romper com a distinção das leis para indígenas e leis para hispânicos, e assim se conformaria a nação para todos. No entanto as relações interétnicas conservam sua dimensão sobreexploradora, os tributos não são revogados, a hierarquia dos caciques não se perpetua como instituição, o individualismo etc. torna a vida indígena ainda mais crua.

A República liberal prevista por Bolívar não teria espaço para hierarquias, o espaço democrático em que todos seriam iguais elimina instituições hierárquicas. Assim o estado republicano desconhece a hierarquia da nobreza e da terra comunitária, coisas que até então eram instituições reconhecidas e usadas na relação da coroa espanhola com as comunidades, mesmo que com muitas falhas e abusos de poder. Quanto ao peso da mita, pongueaje e enconmieda, Sucre, estadista posterior a Bolívar, revoga a lei que havia eliminado o tributo aos indígenas (Mesa, 2008). O então estadista faz isso ao vislumbrar a falência do Estado, que sem os $65 \%$ do orçamento vindo desses tributos não teria como pagar o salário dos empregados públicos. Assim se restabelece a relação de trabalho e exploração, em que o Estado é sustentado pela mão-de-obra indígena, mas lhe dá as costas e não olha por eles em nenhum momento. É a partir dessa percepção que no decorrer da história os movimentos sociais começam a reivindicar também que as riquezas nacionais sejam revertidas em benefício da sociedade como um todo via nacionalização, e com possibilidade de condições justas de trabalho na extração dessas riquezas. Outro sofisma liberal é que a igualdade perante a lei, não incluía o direito de ser representado, o índio não preenche as condições materiais e intelectuais para integrar a ordem republicana, censitária e elitista, não existindo assim como cidadão em seu sentido estrito.

Simon Bolívar, "o libertador", articulou o movimento de independência em vários vice-reinados na América Latina, e representava o pensamento liberal da época. Ele acreditava na construção do cidadão, defendendo o indivíduo como a base da 
sociedade democrática em conformidade com discussões e concepções europeias. E em suas formulações a independência viria acompanhada de decretos vinculados diretamente ao mundo indígena, tais como a igualdade perante a lei, o corte dos altos tributos indígenas, e também institui o reconhecimento da propriedade individual da terra e elimina a hierarquia dos caciques.

O país que acabava de ser criado, baixo os valores republicanos transformara todos seus habitantes em nacionais e concidadãos. De povos à indígenas subjugados, de indígenas à boliviano ou cidadão boliviano. Em um Estado de direito, os cidadãos em igualdade direitos e deveres. Para alguns autores como Silvia Cusicanqui, o primeiro movimento de afirmação e conquista de direitos não é a instalação da república Boliviana, para os indígenas é apenas 143 anos depois, na revolução de 1952 onde os indígenas conquistam direitos políticos e a reforma agrária.

De caráter liberal, com a busca por uma autonomia política baseada no discurso de igualdade. Ainda assim a suposta igualdade da república conservaria as relações de exploração indígena. Para Paultí, a independência dos países da ex-colônia ibérica foi um conflito entre elites americanas e elites da metrópole. Para Manuel Marzal (1993), as políticas indigenistas são projetos dos "vencedores" para integrar o "vencidos" na sociedade que nasce após a conquista. Incluso separa a história dessse indigenismo em três, o primeiro momento que as culturas indígenas são conservadas como tais, porém sobre o controle da defesa e exploração, esse seria o período colonial. Já na sociedade nacional tais culturas devem se assimilar e formar "uma só nação mestiça" (ver Tamayo e Arguedas), seria o indigenismo republicano e a moderna segundo Marzal seria a integração ao nacional conservando certas particularidades próprias.

Nesse momento de configurações locais de poder e de conquistas de cidades e formação de alianças ocorre em 25 de maio de 1811, nas ruínas de Tiahuanaco em frente a uma assembleia multitudinária em que participavam quéchuas e aymaras simbolicamente se anulou o sistema de castas colonial, se declarou a igualdade das raças e se comprometeu que cada intendência enviaria um deputado índio ao Congresso Geral. Nesse mesmo episódio os líderes independentistas liberais atuam com um caráter bastante antirreligioso frente as comunidades que tinham na religiosidade todo o aspecto simbólico das suas diferenças que precisavam ser resgatadas, juntamente com seu modo de vida. Sobre o forjar uma nação, segundo Palti os movimentos de independência na América Latina se configuravam mais como um enfrentamento entre espanhóis americanos e espanhóis europeus, um enfrentamento entre princípios opostos 
mais que uma luta verdadeiramente nacional. Ainda não se definia entre eles critérios de identidade, a não ser a adesão à causa da independência. Anos depois, em 1825, período da Guerra por independência na Bolívia, Simon Bolívar chama um congresso nas ruínas de Cusco, em seu discurso declara sua tristeza ao perceber a condição indígena.

Durante a República, o poder e a ordem eram mantidos através da violência do Estado. Apesar dos ideais republicanos e pensamento liberal a realidade colonial ainda vigora. Junto com o processo de uniformização inato ao Estado nacional, pensadores sociais locais tentavam forjar uma Nação para um Estado sem nação, o papel do indígena variava entre a inclusão pelo embraquecido mestizo, a exclusão dos "collas" e o eventual reconhecimento da sua força cultural, exotizando-os.

Podemos realizar aqui uma breve recapitulação: Katari, o herói rebelde trava sua luta em 1780 e morre em 1781. Na virada do século Bolívar está articulando as elites regionais, em 1810 acontece a primeira iniciativa do que Siles (2009) chama de "movimento independentista" com a Revolução de Chuquisaca, um ano depois ocorre o Congresso indígena nas ruínas de Tihuanaku que reúne várias lideranças andinas, eles decidem sobre o apoio ao movimento independentista, no entanto ficam de fora do processo. Ainda assim declaram o fim do sistema colonial. Siles coloca todos esses eventos ligados ao movimento de independência da Bolívia, inclui todas as manifestações políticas do período como fazendo parte do processo de independência. No entanto, o Congresso indígena e todas as sublevações e movimentos ligados a Katari não se realizaram com o marco do republicanismo, logo tais eventos poderiam também se encaixar em outro marco, o marco por liberação indígena que faz parte de uma luta ainda mais longa.

Os primeiros intelectuais da América Latina no período da República, se preocuparam com o tema da nação e da definição do seu povo e seu ethos. Após a criação do Estado era necessário criar a nação. Os bolivianos, Alcides Arguedas com "Raza de bronze", Tamayo com "La creación de la Pedagogia Nacional" refletem sobre o papel da mestiçagem e seu caráter. Dentre os intelectuais da época, o peruano José Carlos Mariategui foi um dos únicos a se debruçar sobre o problema social e o papel do indígena e a sua condição com a trabalho e terra.

Mesmo com uma elite política em geral bastante conservadora para conceber um projeto de estado ou de políticas que incluíssem a realidade indígena desse novo país, ainda alguns autores tiveram a sensibilidade de discutir o lugar indígena na história da nação boliviana. Alcides Arguedas e Franz Tamayo são algumas dessas vozes que 
representam esse debate filosófico considerável que surgiu após as primeiras décadas de experiência republicana de país independente - ou de um Estado-nação. Em Pueblo Enfermo, Arguedas condensa uma visão negativa do mestiço, como esse tendo os piores defeitos do branco e do índio. Parece descrever um cidadão que possui as marcas da história, mas prefere ignorá-las, alienando-se. O indígena que deixa de existir, que se embranqueceu. $\mathrm{Na}$ verdade, é o mestiço que vai viver as contradições de uma mesma sociedade que guarda dentro de si suas negações, explorações e discriminações. Arguedas afirma finalmente que essa sociedade mestiça parece não ter outro destino que o fracasso. Franz Tamayo, por sua vez, com Criação da Pedagogia Nacional, defende que o futuro do país estará nas mãos dos indígenas - tal publicação soa profética atualmente, eles seriam superiores pela força telúrica da sua gente, e força da sua "raça".

\subsubsection{O MNR e a Revolução de 1952}

A lei de Ex-vinculación representa a culminação de uma década de lutas entre os diversos grupos indígenas e o governo. Estabeleceu-se com ela os termos básicos para a posse da terra indígena que vigoraria até a Revolução de 1952. Muito embora a lei concedesse o direito individual de propriedade da terra aos índios, dessa forma também aboliu a comunidade como uma entidade jurídica. Por outro lado, a lei desmantelou o sistema tributário que há décadas vigorava, sendo substituído por um imposto sobre a propriedade total.

Nesse momento, os índios estavam também perdendo o pouco de poder que detinham como mediadores étnicos, mesmo que agora, eles estivessem se transformando em sujeitos jurídicos de direito civil - diretamente sob a autoridade dos agentes brancos e mestiços e ao cerco de mercado de terras ${ }^{12}$.

As várias tentativas frustradas de terem suas demandas e direitos atendidos construíram o caminho para o recrudescimento da luta. Mesmo depois de outorgada a lei de Ex-vinculación os indígenas não viram atendidas as suas demandas de restituição de terras e concessão de autonomia administrativa às comunidades. A figura do Malku líder rebelde aparece em 1899 e expressa tal descontentamento, se alia com o movimento federalista que os instrumentaliza na luta com armas. Com isso se tenta

\footnotetext{
${ }^{12}$ Larson, Brooke (2004). Trials of Nation Making: Liberalism, Race, and Ethnicity in the Andes, 18101910. Cambridge: Cambridge University Press. pp. 220.
} 
alcançar uma maneira em que pudessem ter uma pressão política efetiva. $\mathrm{Na}$ última década do século XIX acontece uma primeira aliança entre elites locais e grupos indígenas. O movimento federalista do norte contra o sul - governo, coincide com o movimento dos indígenas também querendo pressionar o governo no reclamo das terras usurpadas. Durante o conflito o movimento indígena se autonomiza do movimento de Pando, depois de alguns massacres e da falta de apoio do movimento de Pando em situações chave, ocorre um levante total que autoproclama um estado indígena. Projeto esse frustrado quando líderes como Pando chegam a Oruro - cidade tomada pela massa indígena. Pouco depois Malku, principal líder indígena é acusado dos massacres oriundos da guerra civil a favor do federalismo e colocado na prisão e logo depois assassinado barbaramente em praça pública, seus familiares também são mortos.

É na luta aymara de Malku que pela primeira vez a demanda por autonomia projeta, ainda que de maneira pouco articulada uma consciência de nação, perante si próprios e diante das elites. Para Rivera (1987:73) há um radicalismo na articulação dessa demanda étnico-nacionalista de maneira a não torná-la tão inteligível aos demais segmentos sociais. A morte de Malku simbolizaria então o nascimento do índio político, no sentido de articular-se dentro da política interna e nacional. Os movimentos indígenas subsequentes são menos amplos em sua cobertura territorial e mais específico em suas postulações, e começam a se articular com os setores urbanos e mestiços, ganhando simpatia fora do âmbito rural.

De 1910 a 1930 há um ciclo de rebeliões indígenas que só cessa com a Guerra do Chaco contra o Paraguai. Elas ocorrem no altiplano, nas comunidades de Pacajes (1914), Calamarca, Patacamaya e Sicasica (1914-1915), Inquisivi (1915), Ayo-Ayo (1915-1916), Caquiaviri (1918), Jesus de Machaca (1921) e Chayanta (1927). De maneira conjunta as rebeliões marcam um processo de elaboração de discurso político e de uma moral pela defesa das comunidade indígenas, em contexto de almejada inserção política do índio na vida nacional (Camargo, 2006:135). As demandas ainda atuais podem ser resumidas sendo: 1) a restituição das terras comunitárias usurpadas pela Exvinculación; 2) supressão do serviço militar compulsório; 3) abolição do pongueaje e outros tipos de trabalho não remunerado para o Estado ou para fim particular; 4) estabelecer representação indígena no Congresso e nas diversas instâncias do poder local; 5) escolas para as comunidades; 6) acesso aos principais mercados agrícolas rurais, que normalmente eram monopólio dos donos de haciendas.

O momento após a Guerra do Chaco é de ampliação das reinvindicações sociais. 
$\mathrm{O}$ indigenismo do início do século $\mathrm{XX}$ vai do domínio literário-intelectual para o espaço concreto se firmando como programa ideológico explícito. Se como Tamayo havia afirmado o índio era de grande força, assim como demonstrou em todas as suas lutas e combates, inclusive do Chaco, ele deveria integrá-lo à nação, era preciso então dar-lhes educação, saúde e oportunidade para prosperar e construir um novo país. O indigenismo também serviu como discurso econômico e político dando legitimidade aos sindicatos rurais e aos encontros indígenas regionais (Camargo, 2006:143). Em 1945, Vilarroel, então presidente, frente as várias demandas dos movimentos indígenas instala $\mathrm{o}$ primeiro congresso indigenal, em que se quebra o regime de pongueaje, que só cessa de fato com a Revolução de 1952.

Céspedes vai de encontro com o relato de outros historiadores que colocam a maior parte dos soldados combatentes indígenas como vindo da área do altiplano. Eles seriam da própria região do Chaco (ver segundo capítulo a relação dos Guaranis da região do Chaco com a Guerra). Da desordem social deixada como legado pela Guerra nasce as condições, segundo Céspedes para tomada de consciência, na qual ele mesmo participava enquanto intelectual e da consciência por sua vez nasce a força revolucionária.

Pabón sobre a obra de Céspedes o localiza a partir da íntima relação de "Sangre Mestizo" com um projeto político instrumentalizado através do MNR. Um texto de ficção e relato que milita em seu discurso crítico - dissonante de todas as obras históricas à época (ver Luís Verón e Querejazu Calvo). Segundo Pabón, lá existe uma concepção de sujeito nacional, sujeito esse que é o mestiço, o herói da Guerra. Assim, esse livro de crítica da Guerra do Chaco é um texto fundamental para entender quem é o boliviano-mestiço que Céspedes propõe ser o novo sujeito nacional. As ideias presentes nessa obra estarão também na base da ideologia do Movimiento Nacionalista Revolucionário - MNR, partido do qual foi um dos fundadores e intelectuais mais fortes (Pabón, 1998:170).

Ironicamente,Vieira (2009) aponta o MNR como uma das razões para que não tenha existido mudanças mais radicais:

“A revolução boliviana ocorrida no ano de 1952 nos apresenta, mediante análise, uma prodigiosa e rica exposição de como a luta de classes se desenvolveu na Bolívia naquele ano, pois o proletariado mineiro e os camponeses por pouco não deram fim ao Estado burguês, graças às manobras do MNR (Movimento Nacionalista Revolucionário), que freou o projeto revolucionário popular, antagônico ao projeto sócio-político e econômico proposto pelas classes dominantes como forma de acalmar os 
ânimos populares. O presente artigo tem por objetivo, antes de tudo, fazer justiça histórica ao acontecimento pouco estudado até os dias atuais e também, por meio do materialismo histórico e dialético, elencar os principais aspectos que fizeram desta revolução um conflito antagônico de projetos de nação. Buscamos também compreender os motivos que desencadearam a revolução, bem como suas conquistas e derrotas no contexto da luta de classes." (2009:2028)

Além da Reforma Agrária, a revolução traz o voto universal e a reforma educativa. $\mathrm{O}$ acesso à educação seria a porta para novas oportunidades e o voto universal a possibilidade de se ter representantes indígenas no poder. Ainda assim, persistiam desafios enormes para a construção do Estado nacional moderno boliviano. A Revolução em sua forma, tinha um caráter bastante integrador, há nela uma aglutinação de classes e nenhuma menção à questão da identidade, assim indígenas se conformariam em obreros, camponeses e classe média. O termo índio foi trocado por campesino, numa concepção que unifica a identidade indígena a um conceito mais amplo e palatável ao pensamento de classe da esquerda tradicional, a questão indígena deixa de existir, assim como o passado colonial parece também não ter mais tanta importância (Camargo, 2006:156). A questão indígena foi reduzida à exploração indígena e transmutada à exploração da mais valia. O projeto nacional de tom uníssono seria o desenvolvimento, alcançando a riqueza e melhorando as condições de vida de todos.

A reforma agrária de 1953 que se segue à revolução guarda em si o princípio básico de que a terra é de quem nela trabalha. A partir daí a própria estrutura do ayllu é retomada com bastante força apoiada na sindicalização rural promovida pela Revolução de 1952 e que, posteriormente no governo de Lozada (1993-1997), passa a abrigar-se sobre o status de novos municípios rurais, funcionando sob a dinâmica autônoma da Lei de Participação Popular de 1994 (Camargo, 2006:126).

A reforma agrária, no entanto, se fez, principalmente, nas terras do altiplano. Antes da reforma os grandes proprietários de terra controlavam mais de 95\% das terras cultiváveis do país. Entre as dificuldades que o pós-reforma enfrentou está a falta de preparo técnico para adaptar a produção a pequenos proprietários e pequenos terrenos sem características produtivas adequadas. Os títulos de terra não previam a posse comunitária mudando a organização social de comunidades e o sentido da terra ao determiná-las individualmente por famílias. Mesmo com a tentativa de retomar a estrutura do ayllu, sua unidade atual é bastante distinta da original. Ainda guardam 
muito do valor simbólico ancestral e carrega um valor discursivo inestimável entre os sindicatos rurais e a militância aimará, mas se fixam em territórios contraídos, e sobrepostos às instituições tradicionais, onde estão grêmios e sindicatos que agora dividem suas funções e atribuições.

\subsubsection{Movimento Katarista, CONAMAQ, COB, CSUTCB e MAS}

Nos anos 50 a população aimará urbana cresce. A língua e a cultura no meio urbano é difundida através de fenômenos relacionados com a criação de rádios, e também através do movimento informal na Igreja Católica chamado "Igreja Aimará". A música, os ritos e a língua são propagados no mesmo período em que a Revolução de 1952 quer abolir a palavra e o valor negativo do termo: índio. O acesso dos aimarás às universidade faz com que no final da década de sessenta um movimento autonomeado katarista seja criado em La Paz, a partir do Movimento Universitário Julián Apaza (Muja), da Universidade de La Paz e o Movimento 15 de Noviembre, que se fundiram e se ligaram ao Centro Campesino Tupak Katari em 1971, com a finalidade de expandir o movimento da rádio mantido pela Igreja Católica tanto na área rural como na urbana (Camargo, 2006).

Como explica Albó (2002:121) os kataristas retomam a ênfase étnica e o termo “índio", a partir de uma frase atribuída a aimará Domitilla Quispe, de Azángaro, Peru em 1922 em que afirma "Indio fue el nombre con que nos sometieron, Indio será el nombre con el que nos liberaremos!” (Debate Indianista, 1991:20 apud Albó). O Manifesto de Tiahuanacu de 1973 declara os princípios do katarismo, reconhece a contribuição da Revolução de 1952 na liberação indígena através na redistribuição de terra e os avanços dos direitos políticos (como o voto universal, possibilidade de representação), mas acusa o governo e a sociedade boliviana e o faz evocando lutas anticoloniais e antifundiárias (Camargo, 2006) dos séculos passados percebendo o tempo atual como a manutenção da situação colonial a qual impede que os povos indígenas retomem sua liberdade e autonomia. Por sua vez, assim conclama o manifesto:

"Un Pueblo que oprime a otro no puede ser libre. Nosotros los campesinos quéchuas y aymaras, lo mismo que los de otras culturas autóctonas del país, décimos lo mismo. Nos sentimos economicamente explotados y cultural y politicamente oprimidos." (Lopéz, 2009: 145) 
O intento histórico de Tupac Katari é bandeira do movimento katarista. Sua luta por liberação ecoa pela frase de Katari “morro, mas amanhã voltarei e serei milhões..." e se reestrutura em outro tempo histórico, se reorganiza enquanto força política e na ideia de maioria nacional. O nacionalismo aimará surge enquanto discurso, sob a ideia de como cita Rivera $\left(2003^{13}\right.$ : 179), "há um gigante adormecido" ou como cita Batalla em "México Profundo" há uma civilização negada, ocultada, latente. A arqueologia e atualização que o katarismo faz, reinterpreta mitos como do Pachacuti e do Incarrí. Pachacuti significa a volta de um mundo, renascer, e se torna a busca por espaços de poder dentro do Estado Boliviano (Camargo, 2006), a bandeira símbolo identitário e também símbolo de uma nação é retomada, a Wiphala traz consigo a cosmologia e os valores andinos, assim como também a retomada da ordem, ou da estrutura espacial e sócio-política do ayllu.

Entre a Revolução de 52 apaziguada pela articulação partidária do MNR e o movimento Katarista na década de 60, ocorre a revolta de Laureano Machaka 15 anos antes da ascensão do movimento katarista lidera uma rebelião no departamento de La Paz em 1956, proclama a "República Aimará" logo chamada de "República de Machaka" e governa a província de Camacho por um pouco menos de dois meses, exercendo poder de polícia e cobrando impostos, incluso combateu contrabando na fronteira. Essa experiência irá se refletir em futuras experiências como a LPP, o nacionalismo aimará, o próprio Katarismo e a experiência autonômica de modo geral.

Como ação imediata cria organização próprias que visam renovar o sindicalismo capturado pelo regime militar, que funcionava a partir do "Pacto Militar Campesino 14,", procura uma renovação autônoma dos sindicatos rurais, através de novas lideranças, a aproximação do movimento katarista com os movimentos de esquerda faz com que em 1979 se junte com a Central Obrera Boliviana - COB e formem a CSUTCB. Enquanto bloco, uma de suas principais ações foram os bloqueios de estrada a fim de forçar o governo a recuar em suas decisões. A CSUTCB é o órgão máximo das comunidades rurais e é instrumento de luta social com forte poder de mobilização na área rural, para Albó (2002) a Confederação campesina é sucessora do movimento katarista, tanto historicamente como politicamente: "la CSUTCB sigue siendo en los hechos el marco

\footnotetext{
${ }^{13}$ Rivera Cusicanqui, Silva. “Oprimidos pero no Vencidos”: Luchas del Campesinado Aymara y Qhecwa 1900-1980. Ediciones Yachaywasi, 2003, La Paz-Bolívia.

${ }^{14} \mathrm{O}$ Pacto era uma estrutura formal de articulação entre o sindicalismo e o exército afim de substituir a articulação dos sindicatos com os partidos e o Estado, tal como era no periodo do MNR. Esse Pacto foi fundamental para que o exército derrotasse a guerrilha de Che Guevara em 1967 (Camargo, 2006).
} 
principal en que los andinos bolivianos desarrollan sua consciência y práctica política étnica" (Albó, 2002, p.96). A CSUTCB é criada em 1979 no bojo de outra instituição, a COB, que por sua vez foi formalizada logo após a Revolução de 1952 . A COB ${ }^{15}$ era a mais importante organização sindical. Central criada em 1952, onde os trabalhadores campesinos também tiveram espaço, mas onde os mineiros alcançaram grande poder de influência a partir de um período de co-governo entre MNR e COB logo quando nacionalizadas as minas.

O nacionalismo aimará foi objeto de variadas pesquisas que analisam tanto seus princípios como solidariedade e faccionalismo (Albó, 2002) quanto o seu pioneirismo ao circular pelas instituições políticas tradicionais. Falha na intensão de unificar? O movimento já nasce fragmentado, bifurcado em sua expressão partidária. O movimento katarista se bifurca em Movimento Revolucionário Tupak Katari (MRTK) e o Movimiento Indio Tupac Katari (MITKA). Um braço mais pragmático e outro mais radical, ambos como interlocutor o Estado, que não se unificam simplesmente pela variedade de lideranças com princípios semelhantes porém sem posições unificadas (Rodriguéz, 2012).

Para Linera é por existir um grupo radical que pressiona que se consegue avanços e articulações com o grupo mais pragmático. Uma ligação entre a figura de Cárdenas, que viria ser vice-presidente em 1993 em uma aliança do MRTK com o MNR e o próprio Linera também vice-presidente, que foi do EGTK como Quispe e ao estar no poder muda de posições e tem que fazer concessões. Linera se refere especificamente a Felipe Quispe ${ }^{16}$ ao falar do radicalismo, Malku (que significa "grande líder originário”) do Movimento Indígena Pachakuti e suas duras críticas à política e o governo.

O que no futuro viria ser o braço sindical ironicamente perdeu o elemento da identidade como algo preponderante ao se tornar CSUTCB. É através do MRTKL rebatizado com um L de "liberación" que os primeiros indígenas se tornam deputados, dentre eles está Víctor Hugo Cárdenas que se tornaria futuro vice-presidente do país. As

\footnotetext{
${ }^{15}$ Criada com a Revolução de 1952.

${ }^{16}$ Felipe Quispe foi líder sindical da CSUTCB, secretário-geral da Confederação e em 1984 organizou o exército Guerrilheiro Tupac Katari que em 1990 se mobiliza com a liderança de Quispe em uma insurreição indígena contra o governo, motivo pelo qual Quispe passa cinco anos na prisão. Em 2002 é candidato a presidente da República, junto com Evo. Em 2005 novamente candidato se distingue de Evo por sua posição nacionalista indianista, uma posição autonomista e secessionista que defende a criação de uma república de maioria aimará. Em suas palavras: "Vemos en el mip el instrumento político ideológico de otro Estado, de la nación Qullasuyana. Nosotros no podemos tener relaciones con la otra Bolivia" (Quispe, 2001) (Entrevista: http://www.nodo50.org/pretextos/bolivia1.html)
} 
variadas pesquisas analisam a simbiose entre movimento e partido e também de ambos diante dos seus princípios norteadores originais. A estratégia política aymara derivada do katarismo é fragmentada e ocupa todas as estruturas sociais de poder e de espectros políticos, dos mais radicais aos mais pragmáticos. Albó (2002) definiu a política aimará estando entre o faccionalismo e a solidariedade. Seus princípios se renovam na contraposição dos seus elementos. Mariategui (1928) e Hashizume (2011) trabalham a simbiose entre o pensamento de esquerda revolucionário e o seu encontro com a luta indígena, Hashizume oferece um olhar sobre como o esse pensamento trafega por dentro das instituições políticas ligadas ao Estado.

É certo que a partir da década de 90 ocorrem eventos que aproximaram movimentos sociais e movimentos indígenas. Em 1992 ocorre a contra-comemoração dos 500 anos, juntamente com as organizações do oriente, o movimento cocalero se fortalecia. Estes últimos com posicionamento mais radicais diante do governo central contrastavam com os indígenas do oriente que sob o estímulo de ONGs dentre outros motivos preferiam manter boas relações com as autoridades. Ainda assim, essa data consegue uma aproximação de reivindicações, e o movimento indígena em âmbito nacional inclui entre suas demandas a defesa da coca, que não era um fator cultural no oriente (Barbosa Filho, 2008). O movimento rural que dá origem ao movimento cocaleiro tem como base uma organizaçãoo agrária sindical, mas com o amadurecimento da luta em defesa da coca emerge então uma aproximação dos programas de lutas indígenas. As lideranças desse movimento começam uma trajetorio de protagonismo, em um momento que até as instituições de esquerda estão enfraquecidas meio aos movimentos, e daí esse movimento inicia a sua entrada na política, com o mote de que o povo serve nnao só para votar como para ser votado. Essa é uma continuaçãoo de aproximação dos movimentos com a figura dos partidos, em uma tentativa de mudar, os padrões de participaçãoo democrática. Em março de 1995, reuniram-se as entidades que aglutinavam os camponeses, aí incluídos os cocaleiros, e as representações dos povos indígenas, na histórica Assembleia pela Soberania dos Povos (ASP), na qual se estrutura o que se chamou de Instrumento Político pela Soberania dos Povos (ASP), na qual se estrutura o Instrumento Político pela Soberania dos Povos (IPSP). Encontro dos movimentos e nascimento de um instrumento que se transformou no que hoje vem a ser o MAS - Movimento al Socialismo - com o slogan "votemos por nós mesmos" e com o intuito de renovar as forças representativas pelo frescor de novas lideranças de base. 
As lideranças do que vem a se tornar o MAS tem origem no movimento cocalero do Chapare que ganha força no período da Guerra da Água e do Gás. É assim que se inicia a trajetória de Evo Morales sindicalista cocalero e também ligado ao CSUTCB. O MAS se aproxima das mobilizações e conflitos da Guerra da Água em Cochabamba e Evo Morales cresce na ocasião como articuladore e crítico do Estado, essa articulação que atinge a estrutura do Estado fazendo cair o presidente.

A título de conclusão do capítulo, partindo da definição encontrada no guia de promoção de lideranças indígenas (PROEIB, 2008) retomamos a história do movimento indígena e suas lutas e formas de fazer política em suas primeiras reações contra o poder colonial e a conquista espanhola, passando pelos processos de independências, rebeliões e guerras até culminar nos projetos de construção nacional. Os movimentos indígenas na Bolívia emergem como lutas para construir formas e mecanismos de organização étnica e política anticoloniais que esteja atenta às identidades indígenas e se disponha a compartilhar poder com estas. Na qualidade de uma História que resiste, os movimentos indígenas poderiam ser encarados como uma forma de fazer política que remete a uma moldura constituída desde a colonização.

As fronteiras entre movimento social, partido e governo passaram a ser difíceis de discernir após séculos de resistência e com a ascenção ao poder das bandeiras desses movimentos. Diferenciar entre movimento social e movimento indígena é também arriscado, no entanto é possível identificar trajetórias distintas, como organizações definidas como "movimento indígena" estão a CONAMAQ e a CIDOB - e junto com elas as organizações que as compõem...

O que poderia ser chamado de movimento social na Bolívia são agremiações que tiveram influência da urbanização, dos movimentos marxistas, dos movimentos por luta de terras, que tem como antecedente por sua vez as primeiras resistências indígenas. Após o conselho político de diversas comunidades no período da Guerra para Independência, os povos originários adentram a República como cidadãos nacionais, a partir daí a Revolução de 1952 demanda os direitos que os incluiriam nesse sistema. A partir da visão de esquerda há um movimento adaptativo em que deixam suas identidades em partes, se aproximam das instituições políticas e querem o reconhecimento enquanto sujeitos. Por sua vez os movimentos sociais tradicionais passam por uma trajetória de aproximação com o governo em forma de alianças, alguns se tornam partidos em algum momento em que buscam alcançar algum objetivo prático e outros ao entrar no sistema político se convertem em partidos radicais ou não. 
Usualmente os movimentos indígenas possuem uma posição mais independente do governo e dos partidos políticos, não se interessando em geral em entrar na disputa pelo poder central, diferente dos movimentos sociais que possuem demandas com relação ao território e que dialogam pouco com o sistema econômico vigente e seus interesses por recursos e terras, mesmo que variadas agremiações ligadas a movimentos sociais se reclamem como sujeitos coletivos (ver pesquisa em andamento de Hashizume ${ }^{17}$ ). Isso se tornará uma questão particularmente interessante considerando que os povos tem diminuído demograficamente e se caracterizado também por possuir uma população urbana cada vez maior.

Nesse sentido, a CONAMAQ nasce nos anos noventa, poucos anos depois da criação da CIDOB e parte de lideranças que tem como princípio retomar os princípios da lógica do espaço comunal, representam lideranças do campo que não se sindicalizaram tão fortemente e se consideram mais um governo indígena que uma organização indígena. Vivem em ayllus e comunidades originárias principalmente nos departamentos de Oruro, Potosí e em algumas zonas de La Paz e Chuquisaca. Também o seu projeto de reconstituiçãoo dos territórios indígenas vão ao encontro da formação de um Estado Plurinacional (CONAMAQ, 2005), esta proximidade de propostas fez a CONAMAQ criar alianças com a CIDOB. Ao passo que em alguns momentos se encontra mais distante da CSUTCB e da sua liderança, Felipe Quispe (Chávez, 2008).

Mesmo encontrando semelhanças e diferenças entre diferentes movimentos, as identidades e instituições se sobrepõem no contexto boliviano. Como o caso da CIDOB que se declara não partidária, mas ainda assim seu vice-presidente, Pedro Nuni, ,até 2012 era filiado ao MAS e chegou a se tornar deputado enquanto também exercia o cargo de vice-presidente da CIDOB. Assim como organizações sindicais (ver Hashizume) ligadas ao CSUTCB, mas que possuem posições tão próximas a questão da autonomia que poderia estar associada à CONAMAQ. O decurso temporal em questão, a Assembleia Constituinte - e seu contexto anterior e posterior, aponta para uma grande disposição ao diálogo por parte dos diferentes movimentos. Atualmente, quatro anos após aprovada a Constituição, a despeito do avanço de agendas específicas a cada

\footnotetext{
17 A pesquisa de Maurício Hiroaki Hashizume (em andamento) é um estudo de caso de uma comunidade quéchua na região de Cochabamba ligado ao sindicato rural e que mesmo sendo ligado ao MAS partido do president Evo, fazem parte de um lado do partido que quer avançar no tema das autonomias, autonomias indígenas e TCO. Constituindo-se uma força dissonante dentro do próprio MAS. Com isso Maurício nos alerta o risco em compartimentalizarmos os movimentos indígenas e sociais em suas influências tanto identitárias de uma discussão pós marxista forte nas ONGs internacional e como também da influência e da apropriação do pensamento de esquerda ou marxista.
} 
movimento se percebe uma fragmentação do movimento indígena. É disseminada a opinião que compartilha Rivera (Apud Vacaflor, 2014) ${ }^{18}$ de que não seria uma fragmentação do movimento e sim uma ingerência do governo Evo Morales, que vê nas duas organizações fortes oposições a políticas de seu governo. Os antigos diretórios da CIDOB e da CONAMAQ se articulam e resistem declarando seus mandatos orgânicos a partir de ações de resistência e de uma reunião em Camiri em que consegue juntar centrais das terras baixas e elaborar um documento ${ }^{19}$ onde denunciam ter sido vítimas de violações de direitos humanos perpretados pelo governo.

A dialética da longa duração de Braudel nos ajuda a reconhecer as histórias das resistências indígenas enquanto diferentes articulações inseridas em contextos adaptativos particulares. Ainda assim, não insenta de crítica ou autocrítica os movimentos que subordinam hierarquicamente e/ou entram em conflito com interesses de outro movimento (ver Sarela Paz). No fundo das contradições entre diferentes níveis institucionais está a figura que representa essa encruzilhada: Evo Morales. Enquanto Malku - líder máximo na terminologia aimará, ele sintetiza os vários níveis de transformação e formas identitárias dos processos civilizadores andinos e bolivianos. E enquanto líder do governo e representante do Estado é responsável pelas contradições de uma instituição baseada em um projeto moderno ${ }^{20}$ tentando se refundar enquanto Estado e política a partir de projetos políticos plurais.

\footnotetext{
${ }^{18}$ VACAFLOR, Nancy. Conamaq, la última entidade que marcó distancia del Gobierno. Página Siete, 16 de janeiro de 2014. Disponível em: http://www.paginasiete.bo/nacional/2014/1/16/conamaq-ultimaentidad-marco-distancia-gobierno-11506.html, acessado em 5 de março de 2015.

${ }^{19}$ CIDOB, APG, CNAMIB, CONAMAQ. Mandato organico, politico e ideologico del primer encuentro nacional de los pueblos indigenas (CIDOB, APG, CNAMIB e CONAMAQ). [document] Camiri provincial Cordillera, 26 de novembro de 2013. Disponível em: http://www.erbol.com.bo/archivos_multimedia/mandato_organico_cidob_conamaq, acessado em 5 de março de 2015.

${ }^{20}$ Para uma leitura sobre as dinâmicas da modernidade que o Estado carrega em sua essência ver "A Ocidentalização do Mundo" de Serge Latouche.
} 


\section{Capítulo 2}

\subsection{O contato tardio e a relação dos indígenas das terras baixas com as Missões Jesuíticas}

Neste capítulo, passo a contextualizar a região do "Oriente" como também é conhecida as terras baixas, sobretudo amazônicas, na Bolívia. E quando este "oriente" é "descoberto". A seguir aponto os sentidos ocultos na palavra "descobrir" e sua conotação comum de "achar novas terras". Sairei do sentido comum de "achar", "encontrar", para assumir a palavra como o contrário de cobrir ou encobrir. Como aponta Lema (1997) é apenas nas décadas de 80 e 90 que pesquisadores se interessam pela realidade das terras baixas bolivianas. O evento que marca o "descobrimento" da realidade e da história dessa região é a primeira marcha pela Terra e Dignidade (Lema, 1997) - organizada pela CIDOB e que sai de Santa Cruz, cruzando o país até chegar a La Paz. Também em 1997, Alvorada ${ }^{21}$ tece comentários sobre os diminutos estudos sobre a região. O trabalho dos historiadores mais célebres do país como Mesa, Hernando Zanabria e Rene Moreno - quem inclusive é cruceño, ao tratarem das populações indígenas valorizam a história andina, de forma a circunscrever o imaginário do indígena apenas à realidade andina. $\mathrm{E}$ assim, o tema das pesquisas sobre as terras baixas acaba por se concentrar apenas na explicação das causas do não desenvolvimento na região, que por esconderem em si as explicações de porquê a região não foi povoada e como ela foi explorada e que atores ali incidiam. Para Alvorada a dilatada geografia e a diversidade da região são fatos que explicam tal lacuna. No entanto essas não foram as razões que impediram as pesquisas em regiões semelhantes de países vizinhos a Bolívia.

As histórias dos povos indígenas das terras baixas guarda diferenças com a história da conquista, dominação, proletarização e ocupação do território dos povos indígenas dos Andes. A população mais densa dos Andes abrigou a capital e a maior parte da população nacional. Até a década de 90 a produção científica e intelectual ignorou os indígenas amazônicos, principalmente no seu aspecto político. O protagonismo da política aimará é a perspectiva central para analisar o papel e a história indígena. No entanto, a própria heterogeneidade dos movimentos sociais pode ser

\footnotetext{
21 "La obra de los misioneros Jesuitas en la Amazonia Boliviana", em Archivos Bolivianos de la história
} de la Medicina, 1997. 
explicada pelas diferenças entre perspectivas mais fortes na perspectiva de classe e no outro, uma perspectiva mais preponderante nas diferenças culturais. Esse capítulo se inicia como uma busca pelas estratégias políticas de adaptação e resistência indígena nas terras baixas. Pois as organizações indígenas das terras baixas tem a sua própria história e bebem também na sua fonte para além de absorver a militância andina.

Ao ficar fora - ou à margem - do projeto moderno de Estado nacional, a região parece inexistir para a imaginação nacional apesar de ocupar mais da metade do território nacional. Ademais, em se tratando de identidades o estado moderno tem a necessidade de homogeneizar para governar, no caso, com uma população de maioria indígena é possível que não só o Estado-Nação não apenas homogenize o povo boliviano, como também o "outro" indígena amazônico.

O relato a seguir parte de crônicas, restando uma desconfiança sobre seu caráter fabuloso decorrente das diferenças e contradições entre as fontes. De todo modo, ele serve para contextualizar a região e a tensão que esta impõe sobre a "plurinacionalidade" do altiplano.

Segundo Mann (2007) e Fausto (2000) é encontrada com alguma frequência nessas crônicas uma paisagem de população adensada ao longo das margens dos rios, descrições de grandes cidades e até a existência de cidades com fortificações. Algumas dessas cidades podendo se estender por até 7 quilomêtros à beira rio, com criação de animais e pequenos cultivos. Complementam tais relatos, estudos recentes sobre o bioma amazônico que apontam que a paisagem inicial da floresta era bem menos rica. Teriam sido séculos e séculos de ocupação humana a responsável pelo enriquecimento vegetal e alimentar dessa região. Foi apenas na década de 70 que antropólogos e arqueólogos souberam da existência de corredores ecológicos quilométricos na região do departamento de Beni na Bolívia. Ainda sem estudos arqueológicos, esses corredores sinalizam uma densa população vivendo no meio da floresta e controlando a sua paisagem, em uma espécie de arquitetura da paisagem sofisticada.

Albó (2002:107) diz que depois da Colônia até a fronteira do Tawantinsuyu só se penetrou parcialmente nos vastos campos orientais, assim, muitos grupos étnicos permaneceram lá com suas formas tradicionais de vida. As exceções são as missões jesuíticas que se concentraram em áreas mais remotas e mais ao interior, no Paraguai e no Brasil as quais estavam ligados os povos Guaranis, principalmente. Na Bolívia ocuparam o território amazônico e também a zona do chaco, onde vivem também vários tekohas Guaranis. As Missões ocuparam Moxos e Chiquitos e tinham relativa 
autonomia frente ao poder colonial, o que fez com que criassem, segundo Block (1997) uma "cultura reducional", em cada missão se fundiram identidade e línguas o que gerou uma etnogênese, uma nova cultura com elementos organizativos cruzados, em termos organizativos, artísticos e religiosos. Após as Missões essas "novas culturas" foram mantidas como sendo próprias a essas comunidades. Além disso as Missões tampouco lograram ter o domínio sobre todas as populações.

A primeira Missão adentrou o que hoje é o território boliviano em 1667, apenas três jesuítas, Juan de Soto, José Bermudo e Juliás de Aller chegaram a entrar em Gran Mojos a convite do "cacique" Mego. O objetivo dos jesuítas ali era convencer os indígenas a fazerem parte das Missões. A negociação não seguiu adiante quando os jesuítas deram a entender que se trataria de unir diferentes aldeias, o que na ocasião provocou um rumor de que aqueles Jesuítas entregariam os indígenas aos "cazadores de piezas" ${ }^{22}$. Em 1561, fundação de Santa Cruz, ponto de partida para as excursões em direção a Moxos, a precariedade das estruturas, do caminho até Moxos (de Santa Cruz) impossibilitou a implementação do sistema de encomiendas (em Moxos e arredores). Mas isso também possibilitou que os vizinhos ao departamento entrassem no território para "caçar indígenas" levando-os para a capital para vendê-los.

\subsection{A adaptação, a resistência e a negociação para entrar nas Missões}

Para tornar mais denso relato feito acima, é necessário que se tente superar a lacuna bibliográfica sobre a história da política indígena na região, mas também, que se tente superar o desafio de não tratar a diversidade da região de forma homogênea - em uma região que possui 34 etnias, espalhadas por mais da metade do território nacional e dividida em três partes, Chaco, Oriente e Amazônia ${ }^{23}$. A história dessa região são, na realidade, muitas histórias. A CIDOB e o seu particular funcionamento enquanto confederação ${ }^{24}$ de povos reflete esse desafio. Para uma visão histórica da região das terras baixas optei por usar os trabalhos de Cordoba e Lehms, sobre o povo Mojeño, a partir da sua relação com as Missões. Sendo assim, a história mojenã servirá mais como um caso ilustrativo, que representativo, da história indígena na região. A escolha aí se dá

\footnotetext{
22 História que se tornou a lenda do contato do branco com o povo mojeño: http://nomadaboliviano.blogspot.com.br/2009/09/moxos-la-tierra-de-la-leyenda-de-el.html

${ }^{23}$ São divisões não apenas geográficas, mas também políticas.

${ }^{24}$ Nasce como Central em 1982 e se torna uma Confederação em 1988. Interessante observar a diferença hierárquica e as diferenças de dinâmica de representação entre a ideia de Central e de Confederação.
} 
pela ligação entre passado e presente, e a recente defesa de território mojeño, o TIPNIS. E a relação do Movimento Milenarista com o movimento político indígena, que tem caso parecido nos grupos Guaranis.

O trabalho de Cordoba e Lehm (1999), oferece uma visão histórica de como o povo mojeño se reorganizou socialmente ao negociar a entrada das Missões e também ao fim delas, com o movimento milenarista chamado Loma Santa, em busca de suas terras ancestrais. Por trás desses eventos estão as pressões dos povoados espanhóis locais, o surgimento de novos atores econômicos na região com o ciclo da borracha, e também as lutas entre os povos indígenas. É através de um sistema de colaboração e adaptação complexo que esses povos traçaram sua estratégia de sobrevivência e de luta.

Lehms chama de "pacto reducional" a relação estabelecida em Mojos entre indígenas e missioneiros, em troca de mudanças que seriam vantagens relativas eles acabaram por tolerar outras grandes mudanças nos seus modos de vida. As vantagens seriam ter a proteção dos seus territórios por parte dos missioneros quando houvesse inscursões espanholas, teriam um reforço e ampliação da base produtiva, que permitiria uma troca e um acesso a outros bens, objetos europeus, esses usados na administração da própria Missão e também a liberação de pagar tributos.

Na região Amazônica, ao contrário dos Andes, as sociedades se caracterizavam como sendo de alta dispersão e de mobilidade populacional, além da grande diversidade cultural e linguística. A missão sedentarizava - construindo outra relação com trabalho e natureza e - disciplinando suas forças de trabalho, juntava várias etnias/sociedades em um só espaço, também com homogeneização linguística. Em um cenário onde existem atualmente 34 etnias, em contraposição à quéchua e a aimará, dentre outros povos andinos.

Lehms oferece como prova da eficácia política das missões a inexistência de grandes sublevações em Mojos. Ainda que não seja incólume, é possível perceber a fragilidade dessa interpretação em registros de morte de missioneiros pelas mãos de indígenas (Altamirano [1715] 1979), envenenamento de padres e incêndio em "reducciones" (Eder [1771], 1985 apud Lehm). Além das fugas, as quais os indígenas voltavam às suas lugar de origem e seus modos tradicionais de vida.

Cordoba, então aponta para a necessidade de relativizar a tradicional tese de muitos historiadores, que consideram os indígenas da região amazônica vítimas passivas ou com um comportamento apenas reativo, destinados a perecer diante de enfrentamentos. $\mathrm{Na}$ verdade o que precisa ser mostrado é o caráter específico de suas estratégias de luta 
e o caráter singular da sua política interétnica.

Assim devemos lembrar "desde reações violentas a fugas reiteradas ao monte, até a estruturação de complexos mecanismos de mediação, intercâmbios e pactos que possibilitavam impor determinadas condições e limites a ação missioneira" (Cordoba 2009:137). Um cronista afirma que "não se deixam sujeitar". Em 1695, os Cocamillas na amazônia peruana se confederaram com os Cocamas e Shipibos para matar de uma vez só todos os missioneiros e espanhóis e fechar o caminho das montanhas para que ninguém pudesse entrar. Uma estratégia de retomada dos seus espaços em conflito aberto. A punição aos revoltosos poderia acabar com toda uma etnia, dividindo as famílias em tão pequenos núcleos que impossibilitariam existirem enquanto comunidade (Lehm, 1992:148).

A tese de Lehm é de que em Mojos o elemento inaugural da entrada das Missões não foi como em outros casos de Maynas no Peru, por exemplo, onde houve sufocamento de uma grande rebelião, mas sim em Mojos esteve presente um "interesse dos indígenas em obter um determinado benefício" (1992: 160). Essas diferenças não apontam apenas variações entre a ocupação do Andes e das Terras Baixas, mas também das diferentes missões - há no caso, um certo tom de negociação a respeito das questões de autonomia administrativa, territorial e econômica. E assim aconteceu, repeitando o cenário e as mudanças em torno dos seus territórios e a sua consequente necessidade de apoio para afirmação das suas autonomias - sem institucionalização e com alianças.

Missões Jesuíticas e reduções são tratadas como sinônimos. Especificamente as missões em Moxos - eram coordenadas desde Santa Cruz, ou seja de outro departamento, por sua vez Mojos estava sob "jurisdição" da província jesuítica paraguaia, junto com a de Chiquitos, de Tarija e Charcas. As Missões se deram em duas etapas: $1^{\text {a }}$ ) missioneiros acompanham os conquistadores civis de tal forma que a sua atividade foi complementar a conquista militar - até 1600, muito em busca de riquezas; e $2^{\mathrm{a}}$ ) as missões tinham certa autonomia, daí converterem-se num "outro tipo de conquista" (1987: 12). Na metade do século XVII seu objetivo era catequizar, civilizar e fundar uma nova sociedade cristã nas Américas.

São três as etapas das reducciones nessa região, a primeira de 1690-1720, constitui a etapa de fundação; a etapa de desenvolvimento se dá entre 1720 a 1752 e a última etapa ou a decadência das missões de 1752 a 1764 . No seu ápice a Missão de Moxos chegou a ter 26 reducciones, algumas desapareceram outras foram refundadas várias vezes. Ao chegarem na região identificou-se 26 parcialidades, que foram 
reduzidas a 5 povos de Missão (:155) ao final das missões restavam apenas 4: Loreto, Trinindad, San Javier e Santo Ignacio ${ }^{25}$. Antes Cada reduccion contava com dois padres jesuítas, um incubido da parte material e o outro da espiritual. Aprendiam técnicas para melhor aproveitamento do tempo de trabalho. Com um processo similar, as missõesreducciones seriam mini-estados, com uma diversidade submetida a um processo homogeneizador, sedentarizador e territorializador com uma administração centralizada dos espaços.

Cronistas afirmam que os jesuítas chegaram a reduzir entre 27 e 40 nações indígenas (Bayle, 1986 apud Nostas) - dentro de uma mesma Missão. Nesse sentido antecede o Estado nacional enquanto instituição homogeneizadora. Mas não tiveram sucesso em promover a indiferenciação étnica absoluta. Um fato curioso é que em alguns casos houve a tendência a colocar o quéchua como língua franca já que os missionários vinham dos Andes. Ainda assim os missioneiros aprendiam ao menos uma das línguas indígenas e faziam trabalhos de tradução.

Entre os jesuítas encontravam-se diferentes posições (Marzal, 1981 apud Nostas): 1) aqueles a favor de uma ruptura com os conquistadores espanhóis - saída dos espanhóis e permanência só dos religiosos; 2) outros que propunham diminuir ao máximo o impacto colonial criando um estado indígena à margem do estado espanhol (missão no Paraguai) 3) e a posição majoritária de colaborar com o governo espanhol. E entre a possibilidade de posições particulares, havia uma posição generalizada de humanizar as encomiendas. A tese de Lehm é de que havia em Mojos uma visão favorável ao "estado indígena" com conversão espiritual, já que essa missão era coordenada via Santa Cruz e Santa Cruz estava sob a guarda da Província Jesuítica do Paraguai - que por sua vez mantinha tal posicionamento frente ao espírito colonizador da época.

Variava a estratégia escolhida de acordo com o contexto, ora, podendo ocorrer um intercâmbio, ora podendo haver ataques. A diferença de "estratégia" variava tanto em diferentes missões como também dentro de uma mesma missão. As diferenças étnicas e a heterogeneidade das relações é exemplificada por Cordoba (2009:156), quem informar que os caripunas eram temidos enquanto os araonas eram tidos como “trabalhadores dóceis". Já com os pacaguaras as trocas/escambos eram fáceis e no caso dos cayubabas, esses eram tidos como guias confiáveis. Para além das análises duais

\footnotetext{
${ }^{25}$ Um processo de etnogênese e sobreposição de identidades se deu, a partir do fim das missões os mojeños se identificavam como mojeños javerianos e daí por diante
} 
entre "branco e indígena" mais que lados definidos e institucionalizados, a política da região tinha uma riqueza de alianças e um alto grau de resposta aos fenômenos. A despeito das motivações e estratégias variadas, Cordoba aponta que:

“(...) coexistían el anhelo de asimilación, el deseo de autonomía, la búsqueda de la seguridad material (medicinas, herramientas, vestimentas, dinero) o incluso la manipulación de los actores externos para las rencillas interétnicas tradicionales." (1992:156).

Em dado momento surgiram cabildos como estrutura administrativa, política e econômica, como uma prefeitura, estando a frente do cabildo um indígena. Eram poucos os missioneiros por reduccion, muitas vezes apenas três em uma missão de centenas de pessoas. Após a evolução para a gestão em cabildos, as parcialidades que obdeciam uma divisão étnica passaram a se divididas por ofício.

No período republicano, novos atores sociais e econômicos surgem. Em 1880, é descoberta uma desembocadura do Rio Beni ligando-o ao Rio Mamoré, o que propiciava o acesso ao Atlântico de forma muito mais rápida. Com potencial integrador da região, a descoberta de uma via de escoamento de produção fez com que a exploração da borracha chegasse a Amazônia boliviana. A mão-de-obra que era escassa na região foi suprida por migrantes vindos do sul e indígenas.

Esses setores econômicos pressionavam as autoridades departamentais, advogando pelo fim do sistema missional com o objetivo também de transformá-lo em um benefício "curral". A mão-de-obra indígena ocupou atividades extrativas como a da borracha e da "cascarilla" - havendo casos de indígenas transformados em escravos, através da aquisição de uma dívida. Nesse contexto, as missões ofereciam uma pressão contra a proletarização vivida no context andino. Os indígenas tinham tanta consciência do jogo de alianças que segundo Lehm, concordam em reduzir-se. García Jordán (Apud Cordoba) explica que há uma primeira etapa da conquista em que as reducciones servem à concentração indígena nos centros missionais, apesar disso segue um conflito entre proprietários e missioneiros no que tange a obtenção de terra e mão-de-obra indígena.

No século XIX, com a ruptura do "pacto" e com a saída da Companhia de Jesus das Américas, se constrói o que Lehm chama de "movimento de caráter messiânico" (Lehm:158), movimento de retomada, as populações voltam aos seus territórios tradicionais - recuperam formas tradicionais de vida, com adaptações naturais tanto do período das reducciones e das pré-reducciones. Um período de etnogênese e também o 
início da história do reclame das suas terras, pós-reducciones é inaugurado. $\mathrm{O}$ movimento em sua fase messiânica busca a terra, e o que buscam é uma terra específica chamada Loma Santa $^{26}$ Procuram montes onde cada grupo possa se abrigar de uma previsão de fortes chuvas ${ }^{27}$. O movimento messiânico precede o movimento indígena, o que os une é a busca pela terra. Os dois ensaiam a fusão, mas há um desafio, já que o primeiro funciona para além do Estado e o segundo dialoga com o Estado. A solução criada é que o movimento indígena demanda territórios onde dentro dele a Loma Santa poderá ser encontrada. O movimento coincide com o início do boom da borracha que por sua vez se inicia em 1887. Este messianismo advém do sincretismo religioso mojeno, jesuítico e guarani.

Após a saída da Companhia de Jesus, as resistências seguem em outros pontos das terras baixas como é o caso do povo Guarani na virada do século. O boom da borracha gera uma pressão social e econômica principalmente em Beni e Santa Cruz. A população Guarani seguirá lutando contra a usurpação das suas terras e antes da Guerra do Chaco lidará com um violento recrutamento. Nas terras baixas, o povo Guarani é conhecido como o povo guerreiro ${ }^{28}$, o que é reforçado pelas conhecidas sublevações, mas também por sua participação compulsória na Guerra do Chaco em 1932 contra o Paraguai. Além da perda populacional com a convocação para a Guerra, se viu na condição de ter de lutar e matar Guaranis paraguaios do outro lado da trincheira.

As primeiras resistências guaraníticas foram isoladas e em pequena escala abrangendo algumas parcialidades ou capitanias. É a partir de 1727 que se inicia um período de coalizões e "sublevações gerais", com mais de uma capitania envolvida, nos anos de 1727, 1750 e as maiores de 1793 a 1799 que dissolveu muitas missões franciscanas. Igualmente grandes foram as de 1849 e 1874. Em 1778 o movimento começa a ganhar um caráter messiânico - ocorrida nos principais povoados do povo

${ }^{26}$ Segundo Sarela Paz (2012) a Loma Santa é uma utopia, “(...) como un imaginario de territorio indígena ilimitado entre las comunidades del pueblo moxeño, es una invitación a mirar un largo proceso de luchas y disputas políticas sobre territorialidad indígena y Estado boliviano en claves diferenciadas. Por un lado, una clave profundamente indígena que muestra miradas políticas de la construcción del territorio y poder en la sociedad indígena a través del imaginario discursivo de la Loma Santa". Disponível em: http://www.scielo.org.bo/scielo.php?pid=S1990-74512012000200016\&script=sci_arttext, acessado em março de 2015.

${ }^{27}$ E que de fato ocorreram. Fortes chuvas que provocaram grandes alagamentos, deixaram a população ilhada no períoso justo da campanha do TIPNIS.

${ }^{28}$ Escutado mais de uma vez durante o campo. Em certa feita, durante uma entrevista um militante conservador em Santa Cruz, este de pele alva e traços ibérico-europeu, se apropria da etnicidade ao dizer que ele mesmo era descendente de guaranis. Como qualidade, aponta: um povo guerreiro. É possível que essa identidade que também é regional tenha sido usada como contraponto às etnias do Altiplano. Além da falsa cordialidade da ideia "somos todos indígenas" que dissolve os anseios particulares e reais de um grupo. 
Guarani, Caiza e Mazavi, as rebeliões foram conduzidas pelos "Tumpa" herdeiros dos profetas e xamãs tupis-guaranis do Paraguai e do Brasil. A última rebelião dos Guaranis inicia-se em 1889 também levada por um Tumpa que incita a guerra contra os karai - os brancos, e o faz em apresentações públicas. Em 1891 padres franciscanos de Cuevo tem papel conciliador, no entanto, a guerra se inicia depois que o corregedor de Cuevo estupra e mata uma mulher guarani, parente de Mburuvicha - capitão guarani local (Sanabria, 1972; Chavarría, 1892).

Vinte anos após a Guerra do Chaco, com um Estado boliviano desmoralizado, ocorre a Revolução de 1952 e a reforma agrária de 1953 que se dá principalmente no Altiplano, por sua vez segue em direção às Terras Baixas a expansão latifundiária. A região também desponta como novo local de exploração de recursos naturais, como minérios, petróleo e gás. Além do estabelecimento de elites agroexportadoras mestiças como fortes forças regionais contrapostas ao Altiplano. Chega então, nas Terras Baixas, no último século, enfim, a modernidade do Estado como processo integrador diante da pluralidade de forças.

Propositalmente, nesta seção a história das resistências indígenas na Amazônia não foi dividida em antes ou depois da instituição do Estado Boliviano independente. A razão é a ausência do aparelho do Estado na região, onde as relações interétnicas se dão desde tempos coloniais por atores autônomos em relação aos governos da metrópole ou de Sucre/La Paz. Este padrão se mantém com o surgimento de novos atores econômicos, que trazem com ele fluxos populacionais e novas dinâmicas territoriais.

A saída das missões da região coincide com a entrada desses novos atores sociais e econômicos na Amazônia bolivana. O ciclo da borracha brasileiro se inicia um pouco antes do boliviano, o qual se dá principalmente na região de Pando e Beni. Com a mãode-obra escassa na região a prática da escravização indígena volta a se difundir. As fazendas e esses novos atores econômicos olhavam as missões como um potencial "curral" de onde poderiam aproveitar da força de trabalho indígena. Assim, a saída das missões conta com a influência das autoridades locais que abrem fogo contra a razão da proteção dada pelos missioneros e os gastos com eles.

\subsection{O contexto da articulação dos povos indígenas frente ao Estado}

São elementos que influenciam a articulação indígena na região das terras baixas: a expansão da fronteira agrícola após a Reforma Agrária de 53, pois a política de 
distribuição e redistribuição de terras não inclui a região. O próprio movimento Katarista que retoma a identidade e a condição colonial como discurso de alteridade após um momento de inclusão cidadã da República e o discurso revolucionário incluir apenas a condição de classe. É também na década de 60 e 70, com o avanço das teorias críticas e pós-marxistas que surgem redes de cooperação e ONGs na região amazônica e na década de 90 populações que antes nunca haviam travado contato se articulam ao redor da contra-comemoração dos 500 anos de descobrimento do continente. Conta também como antecedente a própria luta autonômica Guarani que começa a se articular entre suas regiões internas e atingir outros povos indígenas e seguem com o seu protagonismo na região ao dialogar com autoridades inclusive andinas.

A região das terras baixas é mais da metade do território nacional. Os povos ligados a CIDOB estão em sete dos nove departamentos do país. No entanto, o total de habitantes das terras baixas gira em torno de 700.000 em uma população nacional de 10,67 milhões ${ }^{29}$. Os povos das terras baixas tem diferentes histórias de contato e formas de organização social. Há povos em perigo de desaparecimento, como os Pacahuaras com menos de 30 habitantes ou os Yukis com menos de 200, e as populacões com "alto nível organizativo" como os Guaranis com 80.000 habitantes e os Chiquitanos com 70.000 habitantes.

A seção anterior deste trabalho mostra que a "organização" política da resistência nas terras baixas sempre existiu. Sendo necessário deslocar nosso olhar para uma outra realidade histórica e sócio-política, como nos sugere Clastres (ano) para quem as sociedades amazônicas organizam-se contra a centralização do poder em um único ente.

Por outro lado, desde uma perspectiva mais contemporânea, Albó (2002) entende que o processo político reorganizativo das terras baixas bolivianas ocorreu nas terras baixas em período mais recente. Albó (2002, p.115) identifica o processo katarista de retomada da memória indígena como uma das influências para a criação de uma CIDOB, aponta também a experiência de "grupos de selva" peruanos que alcançaram visibilidade a partir de uma ONG dessa região, fundada por antropólogos. Ademais, anterior à criação do movimento indígena da região das terras baixas está a luta por autonomia das comunidades. Tanto os movimentos messiânicos, quanto as lutas que

\footnotetext{
${ }^{29}$ Dados do censo de 2012, Bolívia. Disponível em: http://www.ine.gob.bo:8081/censo2012/PDF/resultadosCPV2012.pdf, acessado a última vez em março de 2015.
} 
cada comunidade travou sozinha pela definição e garantia do direito aos seus territórios tradicionais.

Mburuvichaguasu Bonifacio Barrientos Iyambae, ou Sombra Grande, nasceu próximo à virada do século, no momento em que o último "Tumpa" incitara a guerra contra os karai, adotou o nome do seu meio irmão Bonifacio Barrientos, durante a Guerra do Chaco, na qual lutou. Sua família tradicionalmente ocupava cargos de dirigência e se tornou capitão de sua comunidade em 1936, antes da guerra havia assistido seu irmão nos trâmites para titulação de terras e durante a reforma agrária de 1953, o território de Izozog foi a única terra indígena da região das terras baixas a possuir parte do seu território titulado.

Em 1979, o líder guarani iniciou os primeiros contatos com lideranças de outros povos da região - os chiquitanos, ayoreos, guarayos e guarani-izocenhos. Seria o início de uma articulação que daria origem a CIDOB, fundada oficialmente em 1982 com esses quatro povos, na cidade de Santa Cruz. Sombra Grande morre três anos após a fundação. Um princípio das lideranças à época de Sombra Grande se mantém na organização: "Manter a unidade da organização e a independência dos partidos políticos". Na sua morte, seu filho assume como "capitão grande" guarani e é um dos fundadores da Assembleia del Pueblo Guarani - APG.

\subsubsection{CIDOB - criação e estrutura}

A CIDOB tem como estratégia política principal, ao invés da constituição de um partido ou protestos e combates, as marchas que cruzam o país com um anseio, levam suas demandas à autoridade máxima e levam também a todo o país - ao cruzá-lo a pé. A expressão "em marcha", pode ser compreendida não apenas como caminhada mas como "processo". A expressão em espanhol "poner em marcha" - significa iniciar uma ação, fazer um processo ser iniciado. $\mathrm{O}$ fato do movimento indígena das terras baixas continuar marchando poderia significar uma ação em desenvolvimento e não "para o desenvolvimento", e considerando o contexto histórico de demandas, tal fenômeno seria o desenvolvimento do Estado Plurinacional, o desenvolvimento de visões próprias de desenvolvimento, o desenvolvimento das suas autonomias políticas e suas políticas autonômicas.

Poderia se dizer que as comunidades se articulam em um nível intercomunal e interregional e através da CIDOB se articulam a nível nacional. A CIDOB trabalha em 
rede, com centrais e subcentrais de 34 etnias bolivianas, localizadas predominantemente na região Amazônica e do Chaco. Se identifica como movimento indígena, não partidário, mas estabelece "relações institucionais com as instâncias do estado a nível nacional, com governos locais, com organizações populares nacionais e internacionais, com organismos públicos e privados de desenvolvimento e cooperação"30.

Inicia em 1979 a articulação entre povos da região e em novembro de 1998, durante a $11^{\mathrm{a}}$ GANPI em Camiri participaram pela primeira vez os 34 povos indígenas que a partir dali constituiriam a Confederação (CIDOB, 2007). As 34 etnias reunidas em torno da CIDOB em 1998 são: Guarani, Chiquitano, Ayoreo, Guarayo, Baure, Caninchana, Cayubaba, Itonama, Movima, Moxeño, Moxeño ignaciano, Moxeño Trinitario, Moxeño javeriano, Sirionó, Chimán, Moré, Yuracaré, Chacobo, Pakahuara, Cavineño, Yaminahua, Tacana, Machineri, Araona, Esse-Ejjas, Moseten, Yuki, Tapiete, Weenhayek, Leco, Toromonas, Guarasugwe, Joaquiniano, Reyesano. Ver anexo 1 para mais informações sobre os povos das terras baixas, sua população e distribuição no mapa boliviano sendo possível assim identificar a dinâmica étnica em cada uma das centrais e sua disposição geográfica.

Há um trabalho contínuo desde esse período de criação e articulação de lideranças. Por sua vez cada uma dessas etnias conta com uma representação local. A partir delas é criado e seguem se fortalecendo as seguintes organizações em nível local e regional: Central de Pueblos Indígenas del Beni (CPIB), Central Indígena de la Región Amazónica (CIRABO), Central de Pueblos Étnicos de Santa Cruz (CPESC), Asamblea del Pueblo Guaraní (APG), Organización de Capitanías Weehnayek (ORCAWETA), Central de Pueblos Indígenas de La Paz (CPILAP), Central de Pueblos Indígenas del Trópico Cochabamba (CPITCO), Central Indígena de Pueblos Originarios de la Amazonía de Pando (CIPOAP), Central de Mujeres Indígenas del Beni (CMIB) y Central de Pueblos Étnicos Moxeños del Beni (CPEMB).

As organizações do oriente foram sendo criadas a partir do apoio da CIDOB.

\footnotetext{
${ }^{30}$ Site oficial da CIDOB - http://www.cidobbo.org/index.php?option=com content\&view=article\&id=119:historia-institucional \&Itemid $=85$ (Consultado em dezembro de 2014)
} 


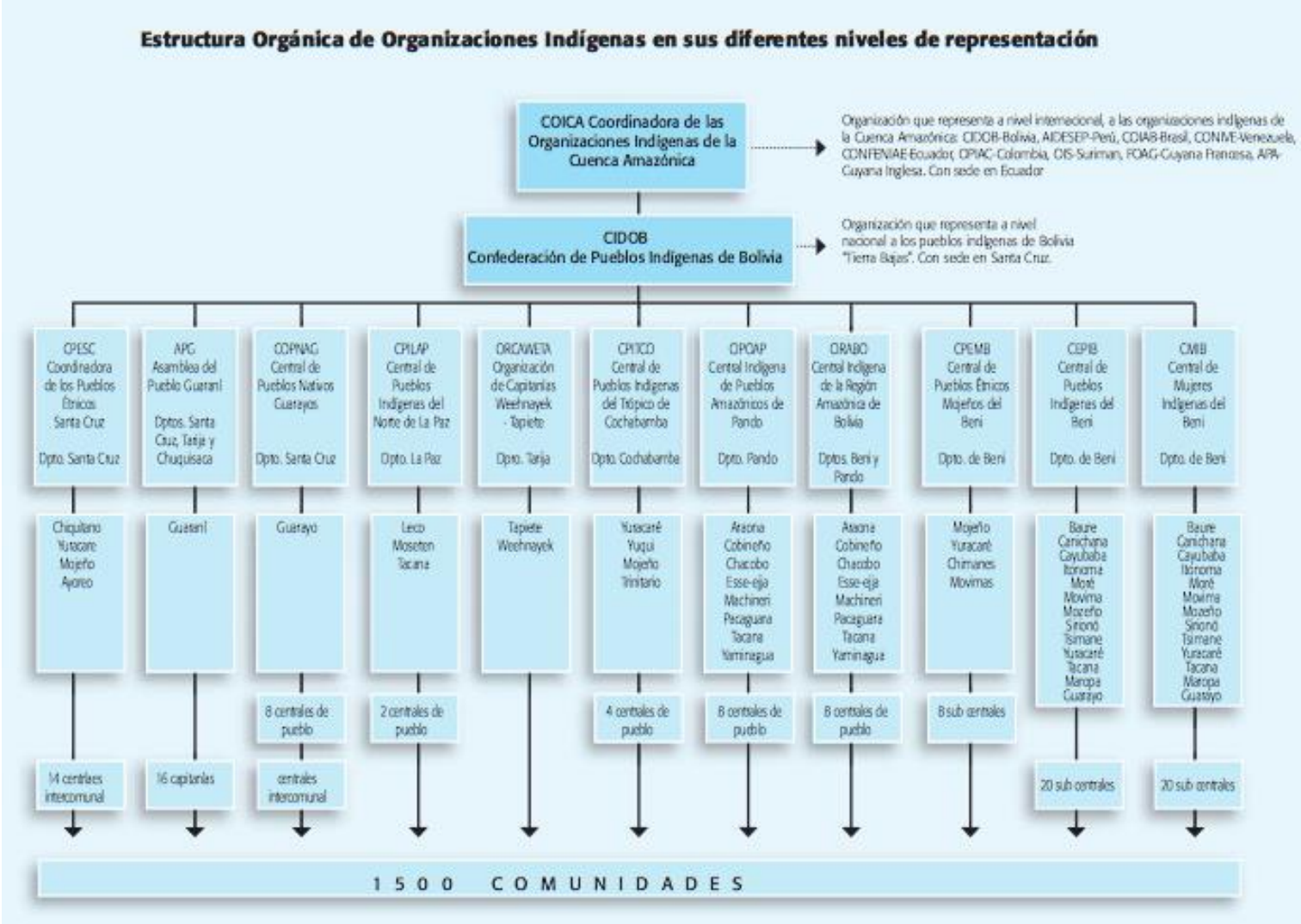

Fonte: Plan Estrategico CIDOB, 2007-2013 (2006)

Autodenominada a organização nacional dos povos das terras baixas, os povos as integram também na qualidade de organizações naturais funcionando a partir dos seus usos e costumes. Inicialmente a letra "C" da CIDOB se refereria a "Central", uma acepção bastante comum nas organizações de classe. $O$ " $C$ " passa a significar "Confederação" e por confederação há acepção política de entidades soberanas que se associam entre si, sem perder a sua soberania, podendo inclusive eventualmente adotar uma constituição. A confederação usualmente toma decisões a partir de uma assembleia com as entidades que fazem parte do arranjo. O termo se refere, usualmente, a um arranjo de Estados modernos e não a outros tipos de organizações, mas, não sendo o objetivo constituírem-se como Estados e considerando o projeto de Plurinacionalidade e da afirmação da soberania desses povos ou nações, utiliza-se a ideia de confederação subvertendo epistemicamente os conceitos tradicionais do Estado Moderno. É possível encarar a própria estrutura de funcionamento da CIDOB e de suas centrais e subcentrais, como parte desse projeto de plurinacionalidade.

Em comum, as subcentrais possuem um corregidor local próximo da comunidade e dos seus problemas, nas centrais estão representantes que muitas vezes já 
foram anteriormente corregidores locales. Essa divisão reflete a própria divisão política tradicional, no seu âmbito local, regional e nacional. A CIDOB tem o seu diretório reunido permanentemente em seu escritório em Santa Cruz. Nenhum outro movimento de âmbito nacional representa os povos das terras baixas. $\mathrm{O}$ quadro abaixo aponta as organizações a nível nacional e a sua delimitação geográfica. A CSUTCB é uma organização que articula todos os movimentos sociais a nível nacional. Tem em paralelo a FNMCB-BS uma organização campesina também de âmbito nacional com a perspectiva de gênero. A CONAMAQ também denominada movimento indígena, apesar de andina está muito próxima a CIDOB no que diz respeito ao seu posicionamento independente frente ao Estado e as demandas por território, autonomia e plurinacionalidade. A APG apesar de ligada ao CIDOB se posiciona em nível nacional paralelamente a CIDOB - sinalizando assim os seus avanços da autonomia guarani.

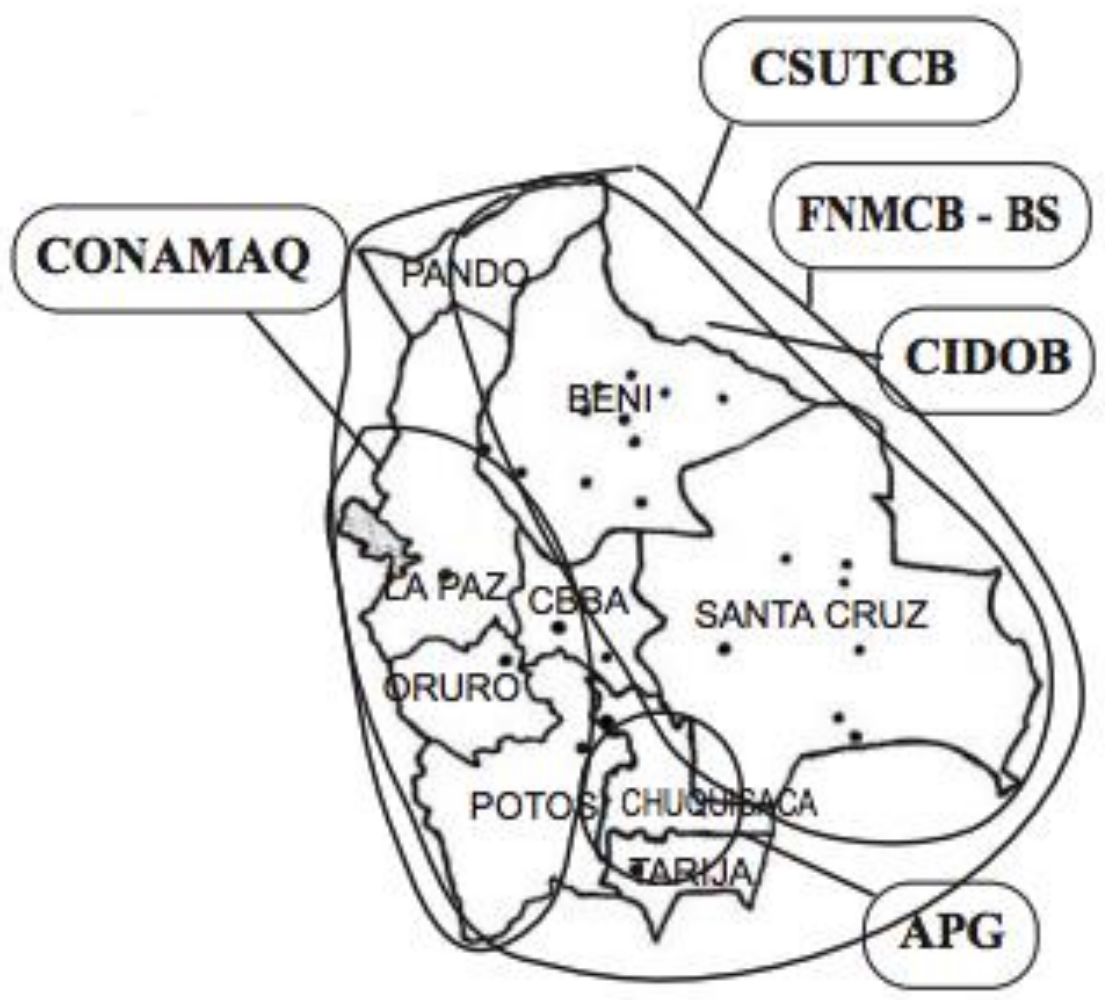

Fonte: PROEIB, Historia del movimento indígena en Bolivia, 2008. Divisão das representações regionais do movimento indígena na Bolívia, e representação do movimento social a nível nacional - também dividido por gênero (FNMCB - las Bartolinas).

A CIDOB possui quatro instâncias de decisão, a GANPI que se reúne de quatro em quatro anos, a ACNPI que se reúne a cada ano podendo também ser chamada em caráter extraordinário e a CNPI que se reúne 4 vezes ao ano. Além disso há o diretório 
permanente em Santa Cruz, que é em si uma instância de decisão. A instância máxima da organização é a Grande Assembleia Nacional de Povos Indígenas (GANPI) que se reúne a cada 4 anos. Nela se avalia a gestão do diretório nacional e se elege a nova diretiva, também toma decisões do desenho estratégico da organização. Aqui a participação é mais ampla, se encontrando o nível regional dos povos e o intercomunal. A Assembleia Consultiva Nacional dos Povos Indígenas - ACNPI se reúne ordinariamente duas vezes por ano - ou extraordinariamente é requerida por duas ou mais organizações regionais. Nela se avaliam e planificam as atividades anuais. Nessa instância participam o diretório nacional e os diretórios das organizações regionais. A Comissão Nacional dos Povos Indígenas (CNPI) por sua vez se reúne a cada três meses, o diretório e mais 8 centrais avaliando os avanços e elaborando plano de ação. Essa instância é responsável pelo cumprimento do Plano Estratégico anual elaborado na ACNPI.

Por exemplo, em 2006, a XIV GANPI é realizada em julho um mês antes do início da Assembleia Constituinte e já expressam preocupação e se declaram focados no avanço do processo constituinte o qual veem como "preso" - e com dificuldade de circular seus informes nas comissões. O tema da terra e território aparece com bastante força. A síntese dos pontos defendidos pelas terras baixas na constituinte são: a) $O$ Estado Plurinacional - no âmbito de sujeitos coletivos na conformação do novo estado, direitos não só de indivíduos, mas de nações; b) "Nossos territórios" - acesso às terras tradicionais, formas próprias de organização social e econômica; c) a propriedade dos recursos naturais nos territórios; d) por sua vez a autonomia indígena - fala do "Estado Unitário Plurinacional Comunitário”, autogoverno - livre determinação, entidades territoriais indígenas, municípios, regiões, suas faculdades: executivas, normativas, administrativas - e ao mesmo tempo fala de formas próprias (CIDOB, 2007 $7^{31}$ ). Para que o Estado reconheça os territórios indígenas de fato é necessário que os incorpore na divisão política administrativa do país. A ideia de autonomia passa por mudanças no Estado. Na GANPI de 2006 também é colocada a necessidade de representação direta na estrutura do novo Estado. Tanto no poder executivo, legislativo, na composição ministerial como também na execução de política pública, com eleição ou nominação por normas próprias.

Há oito comissões de trabalho responsáveis por projetos e outras ações, são elas:

\footnotetext{
${ }^{31}$ Documento distribuído em forma de publicação pela CIDOB. "Plan Estratégico de la CIDOB (20072013).
} 
a) política, b) fortalecimento orgânico c) terra e território, d) recursos naturais, meio ambiente, economia e desenvolvimento próprio, e) comunicação, difusão e pesquisa f) gênero, g) educação e h) saúde, que trabalham a partir das prioridades e ações definidas pelo Plan CIDOB, documento originado a partir da Grande Assembléia, a GANPI. Os temas das comissões fundem as prioridades estabelecidas e a partir disso cada comissão monta um objetivo estratégico, uma linha de ação, resultado e atividades. Há também os projetos - cada projeto mobiliza certas comissões e estruturam as ações propriamente ditas da CIDOB, seus encontros, sua comunicação, articulação, fomento interno. Os projetos relacionados ao "fortalecimento orgânico" visa o fortalecimento político e maior articulação das comunidades. O caráter autônomo presente nos movimentos da região faz com que mais fortalecer a própria instituição (CIDOB) seja necessário o fortalecimento da participação e articulação dos diferentes povos da região.

Adolfo Chávez, conhecido como Don Adolfo está a frente do diretório desde 2006, eleito na GANPI anterior a ACN. A diretiva mantém o princípio da pluralidade ${ }^{32} \mathrm{em}_{\text {sua }}$ composição, com alternância étnica na presidência, sempre que possível. Adolfo é da comunidade Tacana, o Vice-Presidente Pedro Nuni Caity é moxeño-ignácio e há mais seis secretarias, a de terra e território que tem um chiquitano como responsável, a de recursos naturais e desenvolvimento econômico, com um weenhayek, a secretaria de comunicação e pesquisa tacana, e a de educação yuracaré, a secretaria de gênero com uma responsável itonama e a de saúde tacana. Com alternância de diretório de quatro em quatro anos, a possibilidade de encontro de experiências entre esses diferentes grupos sobre os temas em questão.

A CIDOB não tem vinculação partidária, apesar de que muitas das suas lideranças se vinculam a partidos e concorrem a cargos políticos. Como declarado em 2014 após uma Comissão Nacional, próximo às eleições desse ano, a CIDOB tem candidatos, porém não tem partido, o que significa que o apoio a um candidato não se reflete a um apoio a posição dos seus partidos. Pedro Nuni vice-presidente da CIDOB é ligado ao MAS desde antes da sua entrada na diretiva da CIDOB, o que demonstra também por outro lado a própria heterogeneidade de posições dentro do partido de Evo Morales, em 2012, Pedro Nuni renuncia seu cargo de deputado e sai do partido durante o ápice do impasse entre o governo Evo e aqueles em favor da defesa do TIPNIS - território

\footnotetext{
${ }^{32}$ Uma pesquisa ainda não realizada e bastante interessante seria relatar o encontro e o diálogo entre os vários povos do oriente diante da composição e alternância da diretiva de uma instituição que representa as comunidades em nível nacional.
} 
indígena que seria cortado por uma estrada federal. A CIDOB é consciente da importância de possuir representação em diversas esferas de poder, no entanto, possui vínculos mais fortes com os princípios e interesses dos povos que dos partidos que se encontram.

Dentre seus vínculos mais próximos, está também organizações de cooperação governamentais ou não-governamentais. A CIDOB conta com o apoio da CEJIS que oferece consultoria jurídica a organização e faz a edição e publica muito material relacionado às questões indígenas das terras baixas. Financiamento da organização, a CIDOB estimula que cada um das centrais busque o auto-financiamento, pois não é redistribuído para as organizações ligadas a ela em outro nível. Os projetos também possuem financiamento próprio. E o dinheiro é administrado para operacionalizar o diretório por 3 anos com gastos administrativos, gastos para realizar a representação, além do apoio financeiro a 8 dirigentes e o pessoal permanente ligado ao escritório incluso o seu "administrador". Moraes (2014), em entrevista, descreve as limitações do financiamento da organização. A dificuldade, por exemplo, de locomoção de um representante do diretório faz com que muitas questões pousem sob a alçada da representação local, como posicionamento, decisões. O financiamento é um assunto pouco falado e um fator a se considerar é a repulsa da opinião pública pelo dinheiro estrangeiro, tantas vezes usado de forma abusiva com instituições que causavam ingerência política.

Como organização toma posições ora de aproximação com o governo, como aconteceu no período da Constituinte, e ora de rompimento, a fim de marcar seu posicionamento e pressionar o governo. Seus "planteamientos" 33 visam avanços na legislação pró-indígena. Iniciam com o debate interno e são levados na forma de projeto a diversas instituições do Estado, se não forem bem sucedidos, passam à pressão política. Um de seus instrumentos políticos mais contundentes têm sido as marchas, que já levou milhares de pessoas a cruzar o país rumo a capital a fim de ter suas demandas atendidas. As maiores marchas que alcançaram maior comoção nacional foram a quarta em 2002 e a décima em 2011, a quarta marcha pedia uma constituinte originária para

\footnotetext{
${ }^{33}$ 1. m. Acción y efecto de plantear $^{1}$.

Plantear - 1. tr. Tantear, trazar o hacer planta de algo para procurar el acierto en ello.

2. tr. p. us. Establecer o poner en ejecución un sistema, una institución, una reforma, etc.

3. tr. Proponer, suscitar o exponer un problema matemático, un tema, una dificultad o una duda.

4. tr. Enfocar la solución de un problema, lléguese o no a obtenerla. U. t. c. prnl.

em www.rae.es (Consultado em dezembro de 2014)
} 
uma nova constituição e a décima exigia que a consulta prévia fosse realizada no tocante ao projeto de estrada que cortaria ao meio o território indígena e o parque nacional.

O compromisso do governo de Evo Morales, de ser um Estado propulsor do desenvolvimento nacional, foi de encontro com os avanços tido com a criação de mecanismos que permitiam a soberania pluriétnica dos seus espaços. Consultas prévias não realizadas e uma política do atropelo fizeram a organização montar uma campanha de defesa do Parque que comoveu a população de todo o país. Esse também é um momento de forte ataque contra o movimento indígena tanto a CIDOB como a CONAMAQ que se mantinham entre si alinhados. Na tentativa de enfraquecer suas ações, o governo logrou fragmentá-los quando dirigentes ligados ao MAS questionaram o processo interno e se elegeram em paralelo como nova diretiva em 2013.

A perspectiva minoritária da CIDOB se faz sentir na atuação frente a Assembleia Nacional Constituinte. No entanto a luta do CIDOB parece ser feita devagar e sempre. Ela de certa forma encabeça o início do processo com o pedido de uma nova constituição e parece sempre reorientá-lo com seus posicionamentos, discursos e marchas.

\subsubsection{CIDOB e CONAMAQ}

Para Albó, a comemoração dos 500 anos de resistência, em 1992, se transforma num "cenário de oportunidade" para o encontro entre os movimentos indígenas e "surgimento de discursos", agora não marcados apenas por classe. Os primeiros contatos entre CONAMAQ e CIDOB, surgem nesse cenário.

A CIDOB tem como estratégia de luta política o diálogo e a elaboração de plataformas, normalmente propositiva de marcos regulatórios e políticas - plataformas essas visibilizadas através de suas grandes marchas que percorrem o país desde dos anos $80(1986,1987,1990,1996,2000,2002,2003,2010)$. As marchas têm levantado e apresentado suas demandas históricas frente a vários governos, e são mecanismos de visibilizações que se seguem na maior parte das vezes a diálogos e negociações frustradas com autoridades. O processo ocorre sem criação de alianças políticopartidárias, as marchas tem tido a mesma dinâmica durante governos conservadores e governos considerados progressistas no tema, e também se configura como uma forma de participação na democracia - quando as instituições políticas e todos os outros 
mecanismos de diálogo se tornam desgastados (Nostas e Tejada, 2010).

Entre 1986 e 1987, antes da primeira marcha, a CIDOB apresenta proposta de lei indígena com 100.000 assinaturas, alegava com isso "respaldo cidadão", porém o Congresso a rechaça. A diretiva da CIDOB cumpre um papel técnico de elaborar e apresentar as propostas reunidas no interior das centrais e subcentrais. Valência e Égido (2009) apontam essa como a maior característica da Confederação. A colaboração e a articulação política estão bastante presentes na organização nessa fase, no entanto, quando não avançam, usam a ação política direta de marcharem até a capital a partir da central que toma a dianteira da organização da marcha. A estratégia para garantir o direito aos seus territórios passaria pela reforma da Lei INRA (Decreto de 1952).

Para Marcial Fabricano (apud Albuquerque, 2014:79), as quatro primeiras marchas de 1990 a 2004 já seriam acontecimentos que apontam para a plurinacionalização. Fabricano também relaciona as marchas à luta dos povos indígenas e ao aprofundamento da democracia na Bolívia, ainda anterior a chegada de Evo Morales ao poder.

\subsubsection{Primeira Marcha}

Em 1990 a I Marcha Indígena - "Por el Território y la Dignidad”, saem em direção a La Paz. Seria necessário incorporar a lei que serviu para a Reforma Agrária de 1953 a noção de Território Coletivo Originário - TCO. Segundo Albó essa marcha é a "carta de apresentação" dos indígenas das terras baixas frente ao resto do país. A marcha além de mostrar a existência de indígenas nas terras baixas, segundo Valência e Égido (2010), faz com que sejam incorporados formalmente no âmbito jurídico e tenham suas demandas históricas reconhecidas. É nesse momento que oito territórios indígenas são reconhecidos a partir de um processo que passa do âmbito parlamentar para o reconhecimento jurídico, ou do reconhecimento da existência até o reconhecimento de um conjunto de direitos. As conquistas mais imediatas da I Marcha, segundo Claudia Victoria Montaño (2006), é a lei 1257 de 1991, advinda da ratificação do Tratado 169 da OIT (1989) e a Reforma Constitucional de 1994. A reforma reconhece o caráter multiétnico e pluricultural do país em seu primeiro artigo e os direitos sociais dos Territórios Comunitários de Origem - TCO, no art. 171 (Derpic, 2002) (4) $^{34}$ O caráter jurídico dessas conquistas é evidente, no entanto Fabricano (entrevista, apud

\footnotetext{
${ }^{34} \mathrm{http}: / /$ www.scielo.org.bo/scielo.php?pid=S2077-33232002000100002\&script=sci_arttext
} 
Albuquerque, 2014) aponta os limites das conquistas da primeira marcha: “(...) um decreto supremo já não era suficiente, precisava-se ter um título executorial dos territórios" (tradução livre). Os indígenas das terras baixas seguem nas marchas (ou "en marcha"), com o intuito de alterar a lei INRA, que ocorrerá apenas após os esforços da II Marcha.

Os marchistas se encontram com a CONAMAQ nas Cordilheiras dos Andes ${ }^{35}$ antes de chegar a La Paz, sacrificam uma lhama e a CONAMAQ se junta à marcha, tendo uma entrada acompanhada pela mídia e saudada pela população urbana (Albó, 2002), assim, seguem rumo ao “Zócalo". São recebidos pelo governo. À época, o Acuerdo Patriótico (MIR-ADN) é responsável por conduzir esse encontro “demagógico" nas palavras de Andrade (2004).

\subsubsection{Segunda e Terceira Marcha}

A segunda marcha acontece em 1996, membros da CIDOB saem de Samaipata, em Santa Cruz. A marcha exerceria pressão exigindo a aprovação da lei INRA que tinha o risco de não ser aprovada. No entanto, há um conjunto de interesses e um conjunto de legislações também em questão além da Lei INRA, chamada de II Marcha Indígena y Campesina "Por el Territorio, la Tierra, los Derechos Políticos y el Desarrollo" como o nome aponta é a primeira articulação com o movimento campesino, a intenção é levantar um novo processo agrário na perspectiva dos sujeitos coletivos. Isso explica a lei de Participação Popular também de 1996, onde a participação e a representação inseridos em um processo decisório distinto faz com que a política no âmbito local seja feita a partir de organizações não partidárias.

Mas a II Marcha fica conhecida pela aprovação da lei INRA. Com ela inicia-se o processo de saneamento de terras para indígenas, são reconhecidas 33 TCOs (Andrade, 2004), mas ainda assim o processo de reconhecimento de territórios é um processo lento que até hoje não está concluído na Bolívia. Logo a articulação feita com o movimento campesino é desfeita ${ }^{36}$, pois os campesinos não se veem representados pela Lei INRA, impossibilitando acessarem novas terras. No entanto, além da lei INRA se inicia um novo processo agrário de 10 anos que valeria até outubro de 2006, incluindo o Código Mineiro, a Lei Florestal e a Lei de Hidrocarburos (1689) (Montaño, 2006).

\footnotetext{
${ }^{35}$ Ponto mais alto do relevo boliviano à 4700 metros, próximo a entrada de La Paz.

${ }^{36}$ Há trabalhos que discutem a disputa de espaços por pequenos trabalhadores rurais e indígenas e as diferentes percepções da terra, do discurso, seu uso e apropriação. Para uma discussão no âmbito do Brasil comparado a Bolívia, ver pesquisa Thiago Garcia, CEPPAC a ser concluída.
} 
Para Montaño (2006) a II Marcha como a primeira tratava de territórios, com a diferença que passa a amadurecer o elemento de "Nação em potência", em que aparece amadurecida a demanda política indígena por poder, no caso, poder sobre os seus territórios.

Quatro anos depois sai de Montero (Prada, 2012) a III Marcha Indígena - "Por la Tierra el Territorio y los Recursos Naturales", inicialmente indígenas de Pando e Beni fazem a caminhada até Riberalta, extremo norte da Bolívia e depois a Santa Cruz onde aconteceria a GAMPI (Balza, 2001). Apesar dos acordos iniciais dos pontos levantados na GAMPI junto aos enviados do governo ${ }^{37}$ isso não impediu que decidissem marchar até La Paz. Para os indígenas das terras baixas o processo que se segue após a aprovação da Lei INRA não é o "reconhecimento integral" dos seus territórios, ou seja o tema é tratado de forma parcial e setorial então nesse ponto adicionam aos seus discursos o elemento "recursos naturais" os quais os indígenas dependem. É uma tentativa (Montaño, 2006) de reverter as anomalias do saneamento dos territórios, em que técnicos do INRA definiam condutas para o saneamento em um contexto de falta de institucionalidade da lei. Há uma frustração com algumas especificações da Lei INRA, protegendo terras com menos de 500 hectares, causando lentidão e distorção do saneamento e da titulação, a gota d'água se dá quando o governo dá uma concessão a "barracas castañeras", como se chama a produção de castanhas amazônicas na região ${ }^{38}$.

Após a marcha se alcança a aprovação da regulação da Lei INRA, conseguem a reversão das concessões aos produtores de castanha situados em TCO (Montaño, 2006) e a regulação do saneamento em TCO que não mais beneficiaria proprietários de terras menores de 500 hectares (Balza, 2001). Também elimina o Viciministerio de Asuntos Indígenas y Pueblos Originarios - VAIPO e recomenda o tamanho da superfície do TCO ao INRA. A partir de correções e entrada em aspectos técnicos, assim se retoma o debate sobre o processo agrário trazido à tona na marcha anterior. Agora articulando o território, a terra e os seus recursos naturais ao processo agrário. Há aí a dimensão jurídica em que participam novamente indígenas e campesinos e que também se

\footnotetext{
${ }^{37}$ À época o governo havia criado um marco de "diálogo nacional" em que chamava diferentes setores sociais para debater soluções para problemas nacionais. O contexto era a Guerra da Água deflagrada em abril de 2000, a marcha ocorre entre junho e julho do mesmo ano.

${ }^{38}$ Apesar de ser conhecido como "Brazilian nut" no exterior, o maior produtor de Castanha-do-Pará é a Bolívia, responsável por cerca de $50 \%$ da produção mundial e de sua exportação, seguidos do Brasil e Peru. (Homma \& Menezes, 2008) - Comunicado Técnico, ISSN 1517 2244, Setembro, 2008 "Avaliação de uma Indústria Beneficiadora de Castanha-do-Pará, na Microrregião de Cametá, PA.
} 
aproximam dos acontecimentos políticos que fervilham à época de forma a capitalizálos e articular seus próprios interesses, pautando o debate político como aponta (Montaño, 2006), o contexto do debate nacional é sobre a propriedade dos recursos naturais na crise que deflagra a Guerra da Água, onde a empresa estrangeira Bechtel era responsável pelo serviço e pelos preços do abastecimento de água no país. Como sintetiza Moraes (2014) ao alinhar sua luta por territórios e a questão dos recursos naturais os indígenas das terras baixas declaram apoio e também levantam questões próprias do avanço da luta pela terra e território.

Marciano Fabricano relata o processo como algo que se vai conquistando aos poucos e depois segue. Havíamos conseguido, "mas faltava consolidar a economia" (entrevista, apud Moraes).

\subsubsection{Quarta Marcha pela Constituinte}

Em maio de 2002 sai de Santa Cruz a IV Marcha Indígena "Por la Soberania Popular, el Territorio y los Recursos Naturales". A marcha avança para além de um processo agrário e visa transformações estruturais políticas com uma visão própria de desenvolvimento rural, segundo Montaño (2006). Mais de 50 organizações, incluindo o MST Boliviano, se mobilizam entre indígenas e camponeses. Segundo Montaño nesse momento se consolida o "bloco oriente" com um conjunto de organizações das terras baixas num momento em que se elaboram demandas comuns. A articulação acontece não só entre as organizações das terras baixas, mas também junto às organizações andinas. Do momento do encontro, evento único, decorre um grande esforço (Montaño, 2006) para criar o Pacto de Unidad a fim de trabalhar nas propostas para uma Assembléia Constituinte.

Ao longo da marcha, a demanda por uma Assembleia Constituinte fundacional e soberana se torna a demanda central. Diante do conglomerado que intensamente dialogava: indígenas, camponeses, mulheres camponesas, sem-terra, trabalhadores do campo e colonizadores, a assembleia se torna uma demanda em comum. A demanda por uma Assembleia Constituinte traria por consequência o processo agrário e a defesa dos recursos naturais. A CIDOB e as organizações ligadas a ela atuam pela primeira vez em âmbito nacional como atores sócio-políticos, predominantemente.

Isso irá refletir no próprio desenrolar da Crise do Gás que se tornaria Guerra do Gás. Em 2002 o presidente Jorge Quiroga tem o projeto de um gaseoduto que sairia da 
Bolívia e desembocaria em um porto do Pacífico passando pelo Chile, país com o qual a Bolívia alimenta grandes remorsos por conta da Guerra em que a Bolívia perde o acesso ao Pacífico. O presidente ao mexer com o remorso de toda a população, tem com ele um projeto impopular. Por sua vez, os movimentos sociais e indígenas surgem e há uma reviravolta no assunto que deixa de ser sobre infraestrutura, e sim sobre a propriedade desses recursos, questionando as definições e gestão de tais projetos. Dessa forma, levam sua pauta ao debate nacional já sensibilizado com a polêmica do projeto encabeçado pelo governo de Quiroga.

A IV Marcha teve como conquista imediata um convênio com o governo e os partidos políticos, que se comprometeram na ocasião a viabilizar a Assembleia Nacional Constituinte enquanto reforma constituinte e também garantiram um texto definitivo para a "Lei de apoio ao desenvolvimento sustentável" (Andrade, 2004). Há uma longa caminhada de 2002 à 2006 quando os trabalhos da Assembleia Constituinte são iniciados. O processo de entrave e negociação na esfera do congresso anterior a AC será descrito no próximo capítulo. Cabe registrar que Evo Morales foi destituído do seu cargo de deputado em 2002, acusado de terrorismo, meses depois o caso é analisado como tendo sido inconstitucional, no entanto, Evo Morales não reclama seu reposicionamento no congresso. No mesmo ano se candidata a presidente, na agenda estão a Assembleia Constituinte e uma nova política para hidrocarbonetos. Fica em segundo lugar, muito próximo do presidente eleito. Candidato novamente em 2005, e eleito com o MAS sendo maioria no congresso, toma posse em 2006 mesmo ano em que a $\mathrm{AC}$ é finalmente aberta.

\subsection{CIDOB e o Pacto de Unidad}

O Pacto de Unidad foi subscrito por grandes organizações indígenas tais como CSUTCB, CONAMAQ, CIDOB entre outras organizações sociais. O principal objetivo era elaborar demandas comuns relativas à Constituição, coordenando também estratégias políticas - de forma a ganhar mais força, projeção, unidade e diálogo interno. Criado no contexto da Guerra do Gás é natural que o Pacto reflita a "agenda de outubro" elaborada no clímax do conflito, propondo o controle dos recursos naturais para o povo, aparecem com igual importância a autonomia indígena, direitos coletivos e controle dos seus territórios e autonomia campesina, a eliminação do latifúndio e a representação direta no parlamento e o pluralismo jurídico. 
São os povos das terras baixas os protagonistas desta aliança e que alcançam grande visibilidade não só pela estratégia de marchar cruzando o país, mas de se unir forçar com outros movimentos indígenas em embate com o Estado. Mesmo tal arranjo possuindo organizações heterogêneas em variados níveis e também em suas demandas, o pacto conseguiu elaborar uma proposta, usavam como mote a frase "juntos somos fortes", algo bastante parecido com o lema do MAS em seus atos públicos e populares “juntos somos más", essa semelhança e a heterogeneidade dentro do pacto fez com que o MAS assumisse a proposta do Pacto, se apresentando como representante desse conjunto de organizações quando no início dos trabalhos da constituinte.

Sobre o Estado Plurinacional, na sistematização do Pacto de Unidad, de 2006 cabe destacar o seguinte depoimento:

"El Estado Plurinacional se lo plantea en el sentido de reconstitución territorial indígena; permite el autoreconocimiento de cada pueblo indígena como nación. Lo entendemos como el derecho que tienen los pueblos indígenas de reconstituirse como tales. Esto significaría asumir sistemas de gobierno en diversas temáticas y ámbitos; por ejemplo, en el caso educativo, ello implicaría pensar en autoridades educativas y en currículos por pueblosnaciones indígenas originarias. (...) romper la esencia del Estado monocultural que se nos ha impuesto desde la conquista. La propuesta de autonomía indígena puede ser la base para la construcción de este Estado Plurinacional. Pero aquí también tenemos que preguntarnos qué entendemos por autonomía indígena." (Projeto à Constituinte, Pacto de Unidad, 2006)

Como aponta Schavelzon, a ideia de refundação e de descolonização são ideias muito presentes no discurso nacionalista Aymara, tanto no discurso de Quispe como também no de Evo ao assumir o governo com sua promessa de mudanças radicais. No entanto, a proposta constitucional criada no Pacto de Unidad é adotada e defendida pela bancada do MAS presente na Assembleia Constituinte: "coincidiam ao reivindicar o indígena e comunitário como parte essencial da Bolívia, mas davam lugar a formas políticas diferentes, visíveis graças a abertura generosa de um movimento em formação e crescente" (Schavelzon, 2012: 06)

Em 2005 é convocada mais uma "Cumbre Social" para fevereiro de 2006, de forma a consolidar as propostas entre as organizações urbanas e pressionar o Congresso a aprovar a lei que convocaria a ACN. A Cumbre é organizada pelas centrais que representam o grande conjunto de organizações, muitas delas clivadas regionalmente, ou por tipo de identidade ou interesse, uma grande articulação entre os movimentos sociais antes de Evo Morales assumir a presidência, e que se estende até a sua posse e o começo das discussões do congresso sobre a Lei Especial de Convocatória da 
Assembleia Constitucional. É durante a "cumbre" que se formaliza o Pacto de Unidad, uma grande articulação de interesses dos setores sociais populares que se unem para um trabalho conjunto, no contexto de diálogo e participação constitucional com a sociedade civil/organizações sociais frente ao Estado.

Fruto de uma maior articulação para o avanço das marchas, durante a marcha a demanda por uma Assembleia se fortalece, e nesse mesmo momento há um esforço para criar o Pacto a fim de elaborar conjuntamente uma proposta de texto constitucional. Junto ao Pacto de Unidade, escrevem um projeto para o texto constitucional que será considerado em grande parte na redação do texto que será ao final referendado. Nesse período trabalham em colaboração com o governo, romperiam com o governo depois da constituição aprovada, tinham como objetivo pressionar o governo a fim de seguir com as mudanças e garantir leis infraconstitucionais. Demonstrando forte articulação, comunicação e senso estratégico. Os posicionamentos da CIDOB enquanto organização parecem refletir suas lutas, forte senso de gestão, articulação e autonomia política. $\mathrm{O}$ capítulo seguinte visa contextualizar e analisar o posicionamento atual da CIDOB diante da Assamblea Constituinte e do Estado Plurinacional. Essa contextualização se faz necessária para tecer algumas considerações finais sobre o sentido de plurinacionalidade na Bolívia contemporânea desde o ponto de vista de uma organização indígena hoje definida como sendo de oposição ao governo. 


\section{Capítulo 3}

\subsection{Rumo a Assembleia, um longo caminho de 2002 a 2006}

No ano seguinte à IV Marcha, a crise relacionada ao Gás toma maiores proporções. Com a queda do presidente Lozada, Mesa - seu vice, se vê forçado a negociar. Em 2003 o forte uso de repressão militar que Lozada acionado contra as manifestações, com o resultado de 60 mortos é entendido como um ato de desconsideração e não reconhecimento por parte das autoridades, o confronto logo se intensifica em El Alto ${ }^{39}$ e nas regiões próximas e começa a ser chamado de Guerra do Gás. A ação força a renúncia de Lozada, que encarna ao mesmo tempo o arrefecimento das demandas de grupos indígenas, como também encarna uma crise de representação do sistema político. Carlos Mesa, historiador e então vice-presidente à época assume o cargo da presidência e se vê forçado a se desvincular do seu partido para articular e negociar a situação de crise. A demanda por uma Assembleia Constituinte começa a fazer parte, então, da Agenda de Outubro, juntamente com outras demandas, como a das autonomias departamentais. A composição da Agenda demonstra que os setores conservadores também acionaram demandas a fim de polarizar o cenário político, e é em um contexto de extrema polarização que as demandas se veem atravancadas enquanto processos decisórios dentro das instituições do governo.

O "Pacto de Unidad" se reúne em 2004 para elaborar formalmente uma proposta de lei convocatória para a Assembleia Constituinte. Mesa se compromete com a demanda, que seria viabilizada logo após novas eleições, já no governo de Evo Morales. À época de Mesa é criada a Comissão de Constituição do Congresso que concluiu um projeto de lei de convocatória: a Assembleia. Na ocasião, diversas propostas foram reunidas, ao total nove ${ }^{40}$, com diferentes enfoques, critérios de democracia representativa e metodologia para eleger constituintes. No entanto essa comissão não leva a frente a aprovação de uma lei convocatória, segundo Gamboa (2009) pela dificuldade de Mesa de articular o Parlamento. Do ponto de vista dos movimentos, Mesa se compromete diretamente com certas demandas indígenas que garantiriam uma

\footnotetext{
39 Município conurbado à La Paz, considerado um subúrbio de La Paz e conhecido por sua forte articulação política.

${ }^{40}$ Foram apresentadas propostas pela Confederação de Povos Indígenas do Oriente Boliviano (CIDOB), a Universidade Católica Boliviana, os então parlamentares Hugo San Martín (MNR), Ana Barriga (NFR), Evo Morales (MAS), Helen Hayes (MNR) e a Comissão Mista de Constituição da legislatura de 2003-2004.
} 
assembleia originária, e ainda reconhece o mecanismo do referendo, mas ao mesmo tempo o Congresso se articula em um Colégio de Ciudadanos, ou seja parlamentares e setores conservadores como Igreja e colégio de advogados unem forças, o Colégio teria ligação com a Comissão, e não consideraria a perspectiva da sociedade civil indígena na figura de participante/ou demandante do projeto. A articulação do Colégio de Ciudadanos seria uma estratégia para neutralizar a permeabilidade das propostas indígenas para uma Assembleia de caráter contrário aos seus interesses. Como contrapartida ainda mais palpável o colégio de advogado e cabildos (prefeituras) reúnem assinaturas para um referendo de autonomia, e com isso Mesa outorga junto ao congresso eleições de prefeitura (Albó e Ruiz, 2010).

Com um lento processo de confecção da lei de convocatória, surgia em meio a isso uma intensa discussão de temas constitucionais, de forma a afirmar a abrangência e importância da ANC, ou seja, de certa forma debater sobre sua natureza e suas prioridades. Os debates giraram em torno da crise do modelo de democracia representativa que deveria ser mudado para um sistema mais participativo e disposto a introduzir quotas de poder indígena, o fim do ciclo neoliberal e o começo de uma nova era de democracia e (auto-) governos comunitários, a necessidade de retomar uma centralidade estatal que se manifeste claramente na nacionalização dos hidrocarburetos como principal símbolo de enfrentamento de posições coloniais de empresas transnacionais, a descentralização reconsiderada através de um regime de diversos tipos de autonomia, sensibilização sobre os alcances da assembleia como instrumento de refundação estatal, o questionamento absoluto a economia de mercado que deveria ser substituída por um sistema de economia social ou também comunitária.

Já do ponto de vista do setor conservador, ainda durante a época de Mesa, vários parlamentares e outros setores sociais se posicionaram a favor de reformas pontuais sobre a estrutura do Estado, frente a demanda de uma Assembleia Constituinte Originária, a qual inúmeras vezes declararam ser inconstitucional. É nesse momento que os Comitês Cívicos, principalmente os do oriente do país e particularmente o de Santa Cruz, se articulam em um movimento de descentralização frente ao Estado, que ganha termo homônimo ao seu referente indígena: autonomia.

O MAS tentava conter as reivindicações autonomistas, e para isso também tinha uma estratégia centralizadora reforçando o presidencialismo, para tal fim denunciava interesses escusos de grandes empresas transnacionais nas regiões que pediam maior autonomia, um discurso que fazia referência à experiência histórica colonial, e ao 
colonialismo interno de oligarquias e assim o cruzava com uma experiência recente de neoliberalismo, grandes empresas e regionalismo. No entanto, enquanto o governo optava de forma mais simples pela centralização e força de um partido majoritário, o ponto das discussões ainda se configurava complexo com relação ao sistema de representação para a ANC. No entanto a escolha por centralizar vai de encontro com o objetivo de mudar a representatividade exatamente para se obter uma horizontalização política, outra percepção do poder a qual se liga a autonomia e outras ideias de democracia participativa. Ou seja, a centralização do poder tinha função contraditória , pois ocorreria em benefício de contornar a estrutura de poder do "inimigo", mas ao mesmo tempo ele estaria construindo pra si, como estrutura do Estado a possibilidade de se fragilizar a relação com os seus aliados, indígenas e suas comunidade e/ou municípios. No congresso, a pressão por uma maior representação departamental crescia bastante, até que o vice-ministro de Descentralização, Gestão Departamental e Comunal informou que era imprescindível mudar a Lei de Descentralização Administrativa de 1995 para superar as dificuldades de mando presidencial frente ao novo cenário de legitimidade dos prefeitos, também eleitos por voto direto pela primeira vez em 2005. Com isso se assume institucionalmente, de dentro do governo, a necessidade de tocar no assunto de prefeituras e autonomia convencionais e não só indígenas no âmbito da nova constituição.

\subsubsection{Evo é eleito com a promessa de convocar a Assembleia}

Mesa governa até 2005 e o congresso ainda polarizado não chega ao consenso sobre a Lei da Convocatória. O clima é de descrença nas instituições políticas. É o que se pode ouvir do boliviano comum com quem se trava uma conversa corriqueira, a polarização aumenta o nível de insatisfação não importa o espectro ideológico. Assim, estava aberto o caminho para mudanças mais radicais. A subida de Evo traz consigo uma nova agenda, o governo é sustentado, em grande medida, pelo apoio dos movimentos sociais e indígenas. E tem como base aliada um partido que muitas vezes bebe com fervor do espírito e do discurso dos movimentos sociais. Fruto do que Boaventura (2005) apontaria como uma transição paradigmática em que surgem epistemologias do sul mais em contato com sua própria história e demandas e que em uma perspectiva de emancipação social vão em direção a práticas de democracia participativa, consequentemente a democracia representativa aparece em questão.. 
Ainda assim é a partir da conquista de uma maioria no congresso, ou seja um grande aumento de políticos do MAS, que se faz não só a governabilidade de Evo, como também traz a viabilidade de uma Assembleia Constituinte, constituída por uma maioria dentro e fora das instituições. Setores esses, os quais reivindicam um conjunto de mudanças profundas. Em 2005 as principais promessas de Evo é a Assembleia Constituinte e a nacionalização dos hidrocarburos.

No dia que toma posse em janeiro de 2006 , Evo Morales afirma diretamente que se o Poder Legislativo freasse a Assembleia Constituinte, o povo obrigaria os parlamentares a levar em frente o processo. Os deputados da oposição, nesse momento, já levantavam críticas à posição do presidente e, desde o começo, reivindicaram a necessidade de obter dois terços para aprovar uma lei convocatória. Evo por sua vez evoca a demanda das ruas e barganha com a latência dela, mirando em direção ao congresso. A disputa que a oposição levanta sobre os dois terços segue-se por praticamente toda a constituinte e é sustentada pela ideia de equilíbrio do poder - ou aumento qualitativo da representatividade da sua bancada, no momento em que o partido MAS tem a maioria na casa. Para o grosso de dirigentes do MAS, a ocasião sinalizava o contrário, uma Assembleia trazia a oportunidade de utilizar a maioria como mecanismo de solução dos problemas substanciais do país e os requerimentos de reconversão econômica para ir mas além do neoliberalismo (Gamboa, 2008). O impasse entre maioria qualificada e maioria simples poderia ser interpretado como estratégia de entrave a mudanças mais profundas ou radicais.

O resultado final da Lei de Convocatória é frustrante para o Pacto de Unidad e tantos outros movimentos de base - as questões processuais e a forma de representação é a replicação de um jogo político cuja representação se daria também de forma muito similar à fórmula partidária. A Lei de Convocatória define que 255 constituintes a maior parte serão eleitos das 70 circunscrições já registradas tradicionalmente em eleições anteriores. A Lei prevê alianças entre partidos, povos indígenas e outras agremiações. A CIDOB ao fim tem um constituinte, indicado pela organização. Romero ${ }^{41}$ é filiado ao MAS, é advogado de La Paz e possui um histórico de estar próximo à organização em definições ténicas e jurídicas ao longo dos anos, é dele o camalhaço que agrega

\footnotetext{
${ }^{41}$ Romero é intelectual e advogado nascido em La Paz, trabalhou com organizações do Altiplano e da região dos Yungas. Ele se conecta ao oriente através do seu ofício de advogado e a sua consultoria juridical prestada a CEJIS de Trindad. O que demonstra por um lado, a força que essa organização técnico jurídico, a CEJIS tem na criação de um estilo de reivindicação e relação com o Estado utilizando de um discurso e de conteúdos jurídicos pra trafegar na esfera do processo decisório e da criação de políticas.
} 
informações sobre a IV Marcha Indígena do Oriente boliviano, em que resume as demandas desses povos.

Em 12 de fevereiro de 2006, as cotas de participação indígena estavam sendo deslocadas dos debates do congresso. Tanto o projeto do MAS como o da Unidade $\mathrm{Nacional}^{42}$, ignoraram uma representação indígena mais contundente, enquanto o senador Carlos Borth do Podemos, partido da oposição, ironicamente era um dos únicos que concebia de maneira específica a criação de onze circunscrições especiais para povos indígenas minoritários, tais quais populações Guaraní, Chiquitana, Mojeña, Chimán, Tacana, Itonama, Baure, Weenhayek, Uru, Afroboliviana e Kallawaya. Em todas as propostas o critério escolhido enfatizava a distribuição equitativa em função da população e de uma representatividade indígena, no entanto, era muito complexa a combinação de circunscrições nacionais, departamentais e especiais ao mesmo tempo, recai aí um problema das disputas regionais. Para uma representação plurinacional, os povos indígenas do oriente, minoria com $6 \%{ }^{43}$ da população da Bolívia, idealmente teriam que contar com uma representação proporcional a essa porcentagem populacional das terras baixas e a única maneira de consegui-la seria configurando circunscrições especiais.

Dessa forma, o avanço conseguido pelo MAS na comissão se reteve aos assentos especiais com 14 vagas destinadas a povos indígenas, originários e campesinos. No entanto, se o arranjo era interessante para os sindicatos de campesinos que teriam a possibilidade de serem representados se filiando ao partido (MAS ou outros) e ainda por meio dos assentos especiais, o arranjo já não era visto como conquista pelos povos indígenas, que não alcançavam a representatividade que consideravam justas, principalmente no que diz respeito a uma representatividade para se ter uma AC plurinacional, que por sua vez daria origem a um Estado plurinacional.

A proposta da CIDOB $^{44}$ reinvidicava 34 representantes indígenas, um

\footnotetext{
${ }^{42}$ A Unidade Nacional - UN, da oposição, por exemplo sustentava uma composição de apenas 109 constituintes, 27 como base de compensação, distribuídos em três por departamento e outros 82 que expressem uma representação proporcional, eleitos de acordo com o número de habitantes nas circunscrições departamentais.

${ }^{43}$ Dados do Censo de 2001. Consultado em http://www.ine.gob.bo/indice/indice.aspx? $\mathrm{d} 1=08 \& \mathrm{~d} 2=4$. Último acesso em janeiro de 2011.

${ }^{44}$ A CONAMAQ tinha reivindicado ao governo anterior o reconhecimento dos "usos e costumes" como mecanismo para a representação direta na AC. A demanda que eles acreditavam que poderia ter sido aprovada, se o MAS tivesse se comprometido. Por sua vez a CONAMAQ é acusada pelo MAS de impedir o processo, e estar do lado do grupo conservador, ao insistir na demanda por representação direta. Para a CONAMAQ a traição do MAS com os movimentos indígenas e suas comunidades se configurou como uma forma de fazer política ainda num sistema de partidocracia. Meio a essas críticas se cunhou o
} 
representante por cada povo originário do oriente, tal proposta se somou a da Assembleia do Povo Guarani (APG). Um segundo projeto foi elaborado pelo Pacto da Unidade dirigido pela Confederação Sindical Única de Trabalhadores Campesinos de Bolívia (CSUTCB) e apoiadas por organizações do oriente e ocidente que sugeria 26 assembleístas, 16 para as terras altas e 10 para as terras baixas, além da criação de circunscrições especiais. A designação dos candidatos se daria por usos e costumes e seriam eleitos como constituintes por voto universal direto. Havia ainda uma terceira proposta levantada por organizações do ocidente do país que sugeria 240 assembleístas, dos quais mais de 100 vagas teriam que necessariamente para povos originários.

Dentro das propostas apresentadas se seguia em forma de agenda, uma afirmação ao seus espaços e demandas históricas que complementava o seu pedido de representatividade, o tema sobre a exigência do reconhecimento dos seus territórios, identidades étnicas, usos e costumes, assim como a propriedade dos recursos naturais marcavam o pedido de uma representação ao redor de um direito coletivo a representação. Os indígenas diziam aderirem a "uma só Bolívia, mas com nossas próprias nacionalidades para viver segundo nossa própria cultural". A proposta do presidente ia de encontro com os partidos da oposição e ainda não alcançavam o desejo de vários movimentos sociais e indígenas. Evo Morales se declarou na ocasião "órfão" dos movimentos ao mesmo tempo que conclamou, como se sob responsabilidade deles, os movimentos a pressionarem o congresso a aprovar um proposta consensualizada. Evo encaminhou ao congresso, em nome do Poder Executivo o que seria o projeto de lei para a constituinte. A proposta do presidente que representava a proposta do MAS recomendava a eleição de três constituintes em cada uma das 70 circunscrições uninominais, no total, 210 assembleistas. Estava prevista uma cota para mulheres - para cada constituinte homem uma constituinte mulher deveria ocupar a vaga seguinte e vice-versa. O sistema de "representação por maioria absoluta", como desejava o MAS, faria com que se um circunscrição recebesse $50 \%$ dos votos destinado ao partido (MAS), a agrupação cidadã ou ao movimento indígena se obteria, então, os três constituintes relativo as vagas de cada um das circunscrições (3 para cada).

termo "autoconvocatória" para uma Assembleia Constituinte, para fazer referência ao poder de mobilização social frente as decisões de velhos sistemas, e foi um termo que defendia a criação de uma assembleia popular independente e paralela a Assembleia oficial. No entanto, parte dos movimentos indígenas e sociais, incluso aí a CIDOB foram favoráveis a uma estratégia menos fragmentaria, principalmente levando em conta a posição da direita de enfraquecer a $\mathrm{AC}$, eles optaram ao final por estar presentes e fortalecer a característica das suas demandas no processo oficial, mesmo que a estrutura desse processo ainda tivesse configurada em padrões não tão inclusivos para esse novo paradigma. 
As organizações que faziam parte do Pacto de Unidad aliadas a outras organizações $^{45}$ lançam uma declaração em junho de 2006, logo antes das eleições dos constituintes. Com o debate preso em imbróglios de polarizações partidárias e de atropelos conservadores, convocam o povo boliviano e os candidatos à $\mathrm{AC}$ a se assumirem alguns princípios afim de que o processo constituinte construa de fato um novo país, são doze os pontos levantados: a) o Estado Plurinacional, pluricultural e plurilíngue; b) reconstituição das nações originárias e povos indígenas, c) respeito ao exercício pleno dos Direitos Coletivos para nações originárias, povos indígenas e campesinos; d) constitucionalização e conformação da autonomia indígena originária; e) recuperação do domínio originário e da propriedade sobre os recursos naturais; f) acesso ao manejo e controle da exploração dos recursos naturais com direito a consulta, participação e veto; g) participação ativa e direta no controle e fiscalização sobre a administração do Estado através do Poder Cidadano e dos mecanismos de Democracia Participativa; h) reconhecimento dos sistemas jurídicos indígenas; i) domínio e propriedade da biodiversidade, administração, manejo e controla sobre as áreas protegidas e biodiversidade pelas comunidades campesinas indígenas originárias; j) implantação de um modelo econômico ao serviço do bem estar da sociedade com pleno exercício dos nossos próprios sistemas econômicos comunitários; k) participação na elaboração e execuçãoo dos planos de desenvolvimento econômico e social, para melhorar nossas condições de vida; 1) recuperação do domínio originário e propriedade da terra ocupada ancestralmente para os povos indígenas, campesinos e originários, para a redistribuiçãoo justa, com equidade de gênero e equitativa. E com o uso comunal dos recursos.

A eleição dos constituintes ocorreu em julho no mesmo dia do referendo pelas Autonomias Departamentais. O MAS consegue 137 constituintes, seguido do PODEMOS com 60, o restante que se somará ao total de 255 constituintes pertence a pequenos partidos. Na AC, já em 2007 a presença de pequenos partidos se torna essencial para que o MAS articule apoios para conseguir 2/3 para aprovação final da CPE. No nível nacional ganha o "não" pelas autonomias, mas a nível departamental o "sim" ganha em quatro departamentos da meia lua.

Como forma de contornar a força que havia adquirido a questão de autonomias

${ }^{45}$ Assinam a Declaração do II Encontro das Organizações Indígenas, Originárias e Campesinas: CSUTCB, CIDOB, FNMCB-BS, CSCB, CPESC, CONAMAQ, APG, MST, CIPLAP, FSUTCRMDP, CMIB, CAOP, FAOI, NP, CIPYM. 
departamentais o congresso aprovou em março de 2006 as Leis Especiais - 3364 de Convocatória à Assembleia Constituinte juntamente com a Lei 3365 do Referendo para as Autonomias Departamentais. O debate sobre as definições da $\mathrm{AC}$ e o seu modo de representação havia aberto espaço para a questão da descentralização administrativa. A palavra autonomia e a sua ampla semântica faz com que os setores conservadores projetem uma disputa política no debate sobre autonomia e transformem a palavra em tabu. O debate sobre as definições da $\mathrm{AC}$ e o seu modo de representação havia tocado na questão da autonomia departamental, o governo, conseguiu garantir o local da demanda por descentralização, sem que essa demanda de repente se sobrepusesse completamente a um novo tipo de representação priorizasse a representação plurinacional - de outras comunidades.

Por trás disso, uma estratégia dos setores conservadores de forma a antagonizar o governo de Evo Morales. Reflete também o desejo de ter sua importância econômica reconhecida apesar da sua menor população se comparada as outras regiões. A partir daí o critério para definir espaço na $\mathrm{AC}$ e o poder de mobilização dessa ideia eram a estratégia desse setor, que de fato atravancou o debate sobre autonomia. No entanto o que acontece no transcorrer da Constituinte é um acordo de silêncio em que se evita o adentrar em debates potencialmente polêmicos sobre a autonomia indígena, como bem identifica Schavelzon (2013) em seu trabalho sobre a Constituinte:

"Entre la utopía y la realidad, la autonomía indígena y campesina se trataba de un proyecto de reconocimiento estatal a lo que en algunos aspectos ya existía en prácticas e instituciones indígenas, pero que en otros se relacionaba con tendencias a la reconstitución del ayllu, la consolidación de territorios ancestrales y el desarrollo del autogobierno como proyecto a ser construido hacia adelante. El tema traería también controversias, y se movilizarían las ideas de "gueto", de "nueva reducción colonial" (2013:27).

\subsubsection{Regras do Debate - uma questão de maiorias e de constituinte derivativa ou originária}

Ao se falar de AC originária e todo o poder ao povo, as regras do debate refletem essa demanda da seguinte forma, dão poderes absolutos ${ }^{46}$ à $\mathrm{AC}$ acima dos outros poderes, no entanto não é inovadora a respeito da forma da sua composição e representação via constituintes:

\footnotetext{
46 Ver também: "Evo pide más poder para la Asamblea", Los Tiempos, Cochabamba, 6 de agosto de 2006. "La Constituyente empieza con preeminencia indígena"; "Evo declara su subordinación a una Constituyente originaria”, La Razón, La Paz, 6 de agosto de 2006.
} 
"La Asamblea Constituyente es originaria porque radica en la voluntad de cambio del pueblo, como titular de la Soberanía de la Nación. La Asamblea Constituyente es un acontecimiento político extraordinario, emerge de la crisis del Estado, deviene de las luchas sociales, y se instala por mandato popular. La Asamblea Constituyente convocada por Ley No. 3364 de 6 de marzo del 2.006, es unitaria, indivisible, y es la máxima expresión de la democracia. Se encuentra legítimamente por encima del poder constituido. La Asamblea tiene plenos poderes para redactar el nuevo texto constitucional, y tiene como mandato transformar y construir un nuevo Estado Boliviano. En relación con los poderes constituidos, el poder constituyente es la vanguardia del proceso democrático y depositario del mandato social para transformar y construir un nuevo Estado Boliviano. Por las características del proceso constituyente boliviano, la Constituyente no interfiere en el normal funcionamiento de los actuales poderes constituidos hasta la aprobación del nuevo texto constitucional, y el nuevo mapa institucional. Este nuevo texto constitucional será sometido para su aprobación a un referéndum del pueblo boliviano. Desde el momento de su aprobación se hará efectivo el mandato del nuevo texto constitucional y la construcción del nuevo Estado boliviano". Asamblea Constituyente. ("Reglamento de debates"47, Sucre, enero de 2007, p. 3)

Os plenos poderes garantidos pelas regras de debate se tornaram notícia e soavam como um recado do Congresso ao presidente em suas tentativas de pressionar a condução da Assembleia Constituinte, com a vantagem de confundir a opinião pública, dando plenos poderes à uma Assembleia que queria ser originária. A disputa acirrada entre MAS e os outros partidos da oposição por uma composição na Constituinte que viabilizasse uma estratégia que resguardasse seus interesses fez com que, em parte, as propostas dos movimentos e povos indígenas sobre a composição de uma Constituinte Originária ficasse invisibilizada. Como explica Atahuichi ${ }^{48}$ a Constituinte boliviana é derivada e não originária pois a sua composição considerando suas forças sociais não ocupam a maioria da composição o que faria com que apenas mudanças parciais na estrutura do Estado fossem possíveis. Com originária se quer não apenas os plenos poderes, mas se livrar da dependência do próprio legislativo em defini-la e espelhá-la ${ }^{49}$.

Para Gutiérrez $(2006)^{50}$ a AC é ativada pela soberania popular em consequência

\footnotetext{
${ }^{47}$ www.constituyentesoberana.org Último acesso em janeiro de 2011.

48 Atahuichi Salvatierra, R.T. "La Asamblea Constituyente derivada y originaria" em Observatorio de la Economía Latinoamericana, No 74, fevereiro 2007.

Disponível em http://www.eumed.net/cursecon/ecolat/bo/

${ }^{49}$ Mauricio Quiroz Terán. "Una mirada a los conflictos del reglamento de debates: Los constituyente aún dibujan los planes de la nueva casa". En marcha constituyente. Sucre, outubro - 2006. Disponível em http://www.insumisos.com/lecturasinsumisas/Arquitectura\%20de\%20un\%20Constituyente.pdf

${ }^{50}$ José Luis Gutiérrez Sardán. “Asamblea Constituyente Originaria”. En marcha constituyente. Sucre, outubro - 2006. Disponível em http://www.insumisos.com/lecturasinsumisas/Arquitectura $\% 20 \mathrm{de} \% 20 \mathrm{un} \% 20$ Constituyente.pdf
} 
de uma crise estrutural do Estado e também pela insuficiência dos poderes constituídos ou seja, suas três forças. A convocação é um imperativo história onde encontra seus mantados nas quatro marchas indígenas e nas revoltas populares (Guerra da Água e Guerra do Gás) com a saída do presidente. Assim a AC fruto de acontecimentos históricos não dependeria da boa vontade de poderes constituídos, assim:

"El carácter Originario de la Asamblea Constituyente (AC) es una categoría jurídica y política que determina alcances específicos al poder transformador del Estado. Hay quienes pretenden minimizar este hecho, porque consideran que no es trascendente su autocalificación; por el contrario, las tendencias revolucionarias o transformadoras y también las conservadoras le asignan importancia trascendental, por lo que han tencionado un debate en el país.”(Asbun, 2010: 17)

A partir da definição de Gutiérrez, a ousadia dos movimentos é freada pela condução da mudança nas mãos do Estado, ou seja a institucionalização da Assembleia. Antonio Negri (1994) em "El Poder Constituyente - ensaio sobre las alternativas de la modernidad" afirma que o poder constituinte é a vontade de poder, exercício de massas que articulam coesão e consenso, não sendo um processo que se fecha em si, é mais uma "revolução permanente", um processo inacabado devido a uma "insatisfação inaugural".

Esse debate continuava em aberto pois incidia sobre como seria definida a "maioria" nas votações. Como se tornou um empecilho para que a própria AC fosse convocada por lei, o imbróglio foi postergado para que os próprios constituintes a resolvessem. O que se tornou motivo para um longo impasse também durante a AC de mais de seis meses.

Nos primeiros meses da constituinte e ao primeiro sinal que perdiam tempo em demasia com as regras do Debate, a CIDOB e outras organizações acompanham de perto e se posicionam paralelamente a Constituinte. Na Declaração de Camiri, fruto do II Encuentro Social Alternativo, no período de 9 a 11 de setembro de $2005^{51}$, afirmam:

"Reafirmamos la Asamblea Constituyente como una demanda definitivamente nuestra, una demanda de los pueblos, conquistada con el sacrificio de hombres y mujeres, y rechazando el intento de relegitimación y manipulación de los aparatos partidarios y todos los que nos han negado esta oportunidad y ahora se quieren apropiar de ella." (ALAI, 2005 $5^{52}$ )

\footnotetext{
51 Mobilizações e bloqueios de estrada para que haja a convocatória para a Constituinte, houve rechaço governamental frente a convocatória popular por três vezes.

Site do encontro: www.esalternativo.org. Acessado última vez em janeiro de 2011.

Ver também: http://www.gobernabilidad.org.bo/piocs/asamblea-constituyente

${ }^{52}$ Disponível em: http://alainet.org/active/9194\&lang=pt, acessado em janeiro de 2011.
} 
$\mathrm{Na}$ Declaração, as organizações criticavam e formulavam uma posição institucional contra as estratégias de obstrução dos setores conservadores, principalmente no que dizia respeito ao caráter vinculante departamental do referendo autonômico, pois acreditavam que a $\mathrm{AC}$ seria a arena adequada para formular as condições de aplicação das autonomias departamentais, indígenas sem afetar a unidade nacional e garantindo o benefício dos recursos naturais para todo o povo boliviano. $\mathrm{E}$ junto a isso não reconhecem o Comitê Pré-Autonômico de Santa Cruz, afirmando não representar de fato o povo. $\mathrm{Na}$ esteira repudiam os mal tratos físicos e psicológicos às organizações campesinas e indígenas, em larga medida se refere a CIDOB e organizações de alguma forma ligada a ela, em casos de violência difusa na região de Santa Cruz, como também o incêndio de investigação inconclusa, no caso a violência difusa em série foram perpetrados pela "Unión Juvenil Cruceñista" que de forma não oficial representam o braço juvenil - chamado pelas organizações de braço criminal, do Comitê Cívico, assim como o Comitê Pré-Autonômico era orquestrado junto ao governo departamental e Comitê Cívico.

\subsection{Propostas à AC - a proposta da CIDOB e a proposta consensuada do Pacto de} Unidad

Nos dias 15, 16 e 17 de fevereiro de 2006 as organizações sociais se reúnem na "Cumbre Social para a Asamblea Constituyente" realizada na Universidade Autonoma Gabriel René Moreno. A “Cumbre Social” produziu de forma articulada uma proposta constitucional unificada das organizações sociais através do Pacto de Unidad. Os encontros tinham como objetivo sistematizar o conjunto de propostas de diversas organizações representativas. Cada uma delas tinha por sua vez o papel de articular e colher propostas de organizações e comunidades menores ligadas a elas. No primeiro encontro no início de maio de 2006 apresentaram propostas as seguintes organizações: CSUTCB (Confederación Sindical Única de Trabajadores Campesinos de Bolivia), CSCB (Confederación Sindical de Colonizadores de Bolivia), FNMCB-BS (Federación Nacional de Mujeres Campesinas de Bolivia, "Bartolina Sisa”), CIDOB (Confederación Indígena del Oriente Boliviano), CPESC (Central de Pueblos Étnicos de Santa Cruz), e outras organizações de caráter regional, tais quais CSUTCOA (Central Sindical Única de Trabajadores Campesinos Originarios de Ayopaya), CRSUCIR (Central Regional 
Sindical Única de Campesinos Indígenas de Raqaypampa) e FSUTCRMD (Federación Sindical Única de Trabajadores Campesinos, Regional Madre de Dios) também apresentaram propostas. O Movimiento sin Tierra (MST) se fez presente, porém sem apresentar propostas.

Ao final da reunião as organizações decidiram formar uma Comissão Técnica que sistematizaria as propostas em eixos temáticos, e organizaria os pontos convergentes e divergentes para uma discussão posterior da Cumbre Social a ser realizada em Santa Cruz. A Comissão era formada por dirigentes e assessores de algumas das organizações, a comissão contou também com a participação e apoio técnico de outras instituições, tais quais a CENDA - (Centro de Comunicación y Desarrollo Andino) e centro de estudos sociais e jurídicos tais quais a CEPAS e a CEJIS. A comissão dividiu a proposta em 8 eixos: 1) tipo e modelo do Estado, 2) ordenamento territorial e autonomias, 3) recursos naturais, 4) meio ambiente e biodiversidade, 5) direitos e deveres, 6) regime agrário, 7) regime econômico, 8) regime social (saúde e educação). Depois a comissão separou o conteúdo entre o que seria central para ser debatido e proposto na ANC, e o que seriam propostas de leis e políticas públicas. Importa neste trabalho a forma como são discutidas e mantidas as propostas dos movimentos sociais e indígenas. Mesmo que posterior a AC haja desdobramentos e reflexões possíveis sobre o transcurso da trajetória que poderão dar luz aos fatos desse período.

$\mathrm{Na}$ segunda reunião da comissão, conclui-se que as propostas referentes ao modelo do Estado e ao reordenamento territorial seriam o pontos mais importantes para a discussão na ANC. Assim, esses eixos foram mais aprofundados, promovendo uma reflexão sobre o que significaria buscar o reconhecimento da Bolívia como um Estado Plurinacional. Cruzam-se demandas étnicas e sociais antigas condensadas na ideia de participação política e consequências da conquista de autonomia juntamente com um contexto, apontado pelas organizações, de crise do estado monocultural e do modelo centralista. O texto para discussão da segunda reunião da "Cumbre Social" é dividido então entre os eixos centrais: modelo do Estado e reordenamento territorial; e mais seis eixos temáticos. Uma nova ordenação territorial funcionaria como uma política de redistribuição a partir do Estado - não só do reconhecimento da esfera local, ou de indivíduos e suas coletividades culturais, mas também um reconhecimento simbólico e estrutural que dá vazão também a uma nova distribuição material, a partir de sistemas muito próprios e dialógicos. 
A construção conjunta de uma proposta consensuada no âmbito do Pacto de Unidad reuniram as organizações campesinas indígenas e originárias desde maio de 2006. No dia 5 de agosto, um dia antes do início da AC, entregaram a proposta ao presidente da $\mathrm{AC}$, aos assembleistas ligadas ao Pacto e ao vice-presidente Linera. Intitulado "Por um Estado Plurinacional e a autodeterminaçãoo dos povos e nações indígenas, originárias e campesinas" a proposta representa um consenso entre as maiores organizações sociais do país. O MAS e o PODEMOS também apresentaram suas propostas na ocasião, a primeira intitulada "Refundar Bolívia para Vivir Bien" e a segunda, do PODEMOS, "Projeto de Constituição Política. 'Constituyente para la gente", ambas propostas de cúpula, sem participação das organizações. Ao cabo, o MAS acaba por adotar boa parte da proposta do Pacto, cujo conteúdo se tornaram objeto de debate na AC. Um ano depois, o Pacto voltaria a se reunir e elaborar uma proposta que aprofundava a proposta anterior - era também uma estratégia de participação e pressão da $\mathrm{AC}$, esta última intitulada: "Por un Estado Unitario Plurinacional Comunitario, Libre, Independiente, Soberano, Democrático y Social” (SANTOS, 2007).

"Bolívia, livre, independente, soberana, multiétnica e pluricultural" essa era a caracterização do Estado no primeiro artigo depois da reforma constitucional em 1994. Uma mudança de texto impulsionada por demandas de povos indígenas amazônicos e andinos. A afirmação do caráter pluriétnico e pluricultural do país fazia parte de persistentes demandas por parte da CIDOB, e também da CSUTB - no sentido de um desejo de promover maior abertura do Estado, a partir do reconhecimentos dessas diversidades. Ademais nesse conjunto de reformas, houve também a inclusão do artigo 171, que introduz o conceito de TCO - Terras Comunitárias de Origem, um passo para o reconhecimento de recursos, costumes e formas de governo interno as comunidades originárias.

Na proposta, nos debates iniciais, o Estado se apresenta a partir de um conjunto de adjetivos que se referem todos a ideia de pluralidade, Estado: plurinacional, multinacional, pluriétnico, pluricultural, intercultural, plurilíngue, multilíngue. A sua condição jurídica é a de um Estado social, uma república unitária, descentralizada que reconhece as autonomias das suas entidades territoriais para o exercício dos seus direitos, reconhece a reconstituição dos territórios indígenas com autonomias, gestão territorial indígena originária, autodeterminação, autogoverno e autoadministração de cada nação originária. Fica claro já nas primeiras propostas a conexão do que seria plurinacional - seguida com adjetivos que conectam língua, cultura, etnia, junto com o 
enfoque da descentralização do Estado usando os princípios que regem a ideia de autonomia. Na proposta final o artigo que caracteriza o Estado é o artigo 2, e em sua forma final faz referência a um pluralismo comunitário, a interculturalidade e a perspectiva material do reconhecimento da ideia de redistribuição:

"A Bolívia se caracteriza como um Estado Unitário Plurinacional Comunitário, livre, independente, soberano, democrático e social, que reconhece o pluralismo jurídico, político, cultural y linguístico; descentralizado e com autonomias territoriais.

Garante a igual dignidade das pessoas, das nações, povos e culturas e fomenta o respeito mútuo e o diálogo intercultural.

Segundo os princípios de unidade, solidariedade, reciprocidade, complementariedade, harmonia, equilíbrio, equidade social e de gênero na participação, distribuição e redistribuição dos produtos e bens sociais, com equidade de gênero, para "viver bem"." (Artigo 2, Proposta Consensuada do Pacto de Unidad, 2006 Tradução livre)

Nas propostas iniciais do pacto, o Estado é caracterizado a partir de um conjunto de princípios e valores, ao qual se apoia, sendo esses: a) unidade, b) democracia, c) soberania (no plano internacional), d) soberania popular, e) independência, f) solidariedade, g) complementariedade, reciprocidade e redistribuição, h) rotatividade, i) transparência, j) revogabilidade (passível de anulação, revogação), l) igualdade (discriminação positiva), m) integridade territorial, n) cooperação, o) responsabilidade, p) Suma Qamaña ou Sumak Kawsay, ama sua, ama llulla, ama qhella, q) poder de veto, r) gestão comunitária; e como valores: a) liberdade, b) igualdade, c) respeito a vida, d) solidariedade, e) preeminência dos Direitos Humanos e, f) querer (munay), saber (yachay), fazer (ruway), poder (atiy).

O princípio da unidade estabelece-se como uma reafirmação conjunta de um novo pacto social, que deve ser feito a partir de vínculos de solidariedade, princípio que estabelece uma comunidade política maior, imaginada, mesmo que se reestruture outras unidades tais quais a da autonomia. Os valores do Estado coincidem com os valores declarados na constituição francesa de 1789, liberdade, igualdade e solidariedade, é adicionada ainda o paradigma ético dos direitos humanos que serve de apoio à algumas lutas sociais, e também tem-se o paradigma filosófico aimará que remete a uma perspectiva de empoderamento humano. Quando passam por várias etapas de discussões os valores condensados na proposta final são liberdade, igualdade, dignidade humana e justiça social (Artigo 4, Proposta do Pacto de Unidade, 2006).

O novo pacto social refunda o desejo popular sob o marco da democracia, 
arejando as instituições democráticas com sua horizontalização, que vem não só com a descentralização promovida através das autonomias. Além de reconhecer a democracia comunitária, o novo regime do Estado é o da democracia representativa e também participativa com outros mecanismos de democracia direta, se reconhece então, mecanismos de participação que seriam: a) Assembleia Constituinte (podendo ser convocada a partir do desejo popular), b) referendo, c) plebiscito, d) iniciativa legislativa cidadã, e) ação popular, f) veto popular, g) revocatória de mandato e outros mecanismos de participação direta, que se relacionem aos princípios declarados tais quais a rotatividade, a soberania popular, a revogabilidade e a transparência ${ }^{53}$. Surgem debates sobre o limite das aplicações dos mecanismos de de participação direta. As experiências de referendo e plebiscitos contaram com críticas sobre a real possibilidade de informar e promover um debate profundo sobre temas, em que a busca por definição impulsionaram novos discursos e estratégias políticas, podendo esses mecanismos se tornarem apenas jogos de participação retórica ou populista.

Sobre a proposta de um novo modelo de Estado quanto os seus poderes, as mudanças se concentram na estratégia de composição de uma Câmara Plurinacional, a proposta de um quarto poder social, assim como um judiciário plural, que não só reconheça a justiça indígena mas que também tenha em sua composição representantes indígenas. Um debate intenso se adiantava sobre o número de assentos especiais indígenas da Câmara Plurinacional, e também estava sendo proposto uma comunicação plurilíngue no interior do legislativo. A CIDOB também propõe a extinção do Senado, visto pela CIDOB como uma "câmera dos lordes" - um filtro conservador e elitista da representação popular da câmera (CIDOB, 2001), no entanto essa proposta não chega a compor a proposta final do Pacto de Unidad. Há uma discussão se as representações da corte estabelecidas por meio de indicação do legislativo ou por meio de voto - esta última proposta foi objeto de crítica da extrema politização que os movimentos sociais estavam propondo as instituições políticas e burocráticas, no entanto essa seria uma estratégia, não se sabe se ideal, para discutir e abrir instituições e suas práticas, a fim de adequá-las a novos paradigmas. O estabelecimento do quarto poder, ora era proposto na figura de uma instituição já existente, a defensoria pública, mas houve sugestões de novas instituições com composições ainda mais populares a fim cumprir a

53 A proposta acompanha alguns objetivos pontuais para a política do Estado como perseguir o princípio moral ético de terminar com todo o tipo de corrupção, assim como o objetivo econômico e social de promover uma redistribuição dos benefícios dos recursos naturais relativo a um principio de equidade, respeitando o princípio de complementariedade com a natureza. 
accountability dos poderes representativos, e também objetar e vetar políticas do governo além de estar mais próximo ao legislativo e levantar demandas, como o caso de um conselho civil de controle social, ou conselho cidadão de controle estatal.

Além de promover a participação política da população a partir de tais mecanismos democráticos, as propostas temáticas da constituição dão ênfase na responsabilidade do Estado em oferecer serviços públicos sociais, por conseguinte, essa política seria possível com um papel econômico do Estado, nacionalizando recursos naturais a serem explorados. As propostas desde o início relacionam os projetos de desenvolvimento econômico, tanto no âmbito do Estado quanto privado, à responsabilidade com o meio ambiente. Assim um compromisso com a democracia e com o meio ambiente é traçado quando no marco da consulta as populações, no compromisso de uma política integral para o espaço fronteiriço - que abarque meio ambiente, identidade, desenvolvimento cultural e econômico.

Outros passos foram tomados em direção a consolidação do pluralismo, o texto que se refere ao respeito as crenças culturais, se declararia desde então um Estado laico, a língua oficial passaria a ser o espanhol mais todas as línguas faladas no país. As 37 línguas seriam protegidas e desenvolvidas em cada uma das regiões em que a cultura fosse mais representativa, sendo missão dos burocratas possibilitar esse acesso e contato com tais línguas. Durante os primeiros debates foram debatidas diferentes propostas sobre o tema militar, desde a extinção da força, à defesa da tradicional obrigatoriedade do serviço, a proposta final defende que o alistamento seja voluntário aos indígenas. A APG cogita a criação de uma polícia própria na área do seu território.

Por sua vez, a proposta da CIDOB é extensa e abarca com detalhes variados temas, conta com mais de 80 páginas de texto, em um formato que poderia ser utilizado como proposta formal para artigos constitucionais. O texto percorre também os assuntos constitucionais tradicionais, e há diversas propostas que garantem o compromisso do Estado em temas sociais. A proposta se divide em direitos civis, políticos, sociais, econômicos, coletivos, territoriais, culturais - proteção da cultura material e nãomaterial, meio ambiente e recursos naturais - regulando a exploração e gestão sustentável. Há um inicial e incipiente debate sobre que tipo de concessões poderiam ser feitas a instituições privadas para que a tecnologia de exploração fosse viabilizada, e ainda o debate sobre a propriedade dos recursos naturais não alcança profundidade na articulação relacional entre as propostas de domínio e responsabilidade e mecanismos de gestão ambiental. 


\subsubsection{Ordenamento territorial e a questão da autonomia nas propostas do CIDOB e do Pacto de Unidad}

No começo do debate do Pacto de Unidad as propostas foram divididas, o ordenamento territorial é parte do seu eixo central. A questão da autonomia indígena seria parte central do novo Estado a ser fundado. No entanto, no texto final o tema da autonomia indígena é citada de forma mais pontual e fracionada - com mais detalhes em outra sessão, em grande medida por conta da apropriação do setor conservador do termo, para discutir a consolidação da descentralização entre autarquias da União - ou seja, definições sobre as autonomias departamentais e a estratégia adotada pelo governo de contornar a equiparação dos conceitos de autonomia, evitando o debate e o termo em si.

A autonomia é baseada em um reconhecimento não só da igualdade, mas principalmente da diferença, de forma a não transformar a igualdade em uniformidade. Os direitos coletivos complementam os direitos individuais. E fazem parte do arcabouço dos direitos coletivos os direitos a autodeterminação, autogoverno e autoadministração que servem de base para a demanda da autonomia. Para o Pacto de Unidad o direito à autodeterminação seria a possibilidade de praticar a verdadeira liberdade, a partir da autodeterminação cultural, territorial e administrativa seria possível viver a partir de normas próprias baseadas nos princípios próprios das suas culturas, conservando as estruturas e valores de igualdade e respeito dentro de suas culturas. O direito ao autogoverno se refere a poder de comando, podendo eleger autoridades e estruturas próprias, o que para essas populações marcaria uma relação de transparência e confiança dentro da comunidade. E o direito à autoadministração estaria ligado à administração de recursos naturais, bens territoriais, educação, saúde, e outras instituições locais, jurídicas, econômicas. E sobreposto a essa administração local está o direito à consulta, que respeita esse compromisso local com os recursos e no caso de projetos iniciados por outras instâncias, convoca a participação do sujeito coletivo nos processos de gestão pública, participação de benefícios, compensação e controle dos recursos.

Inicialmente, quem sugere uma definição para as autonomias no Pacto de Unidad é a APG:

"A autonomia indígena é a condição e o princípio de liberdade do nosso povo que impregna o ser individual e social como categoria fundamental de antidominação e de autodeterminação, baseado em princípios fundamentais e 
generativo que são os motores da unidade e da articulação social, econômica ao interior do nosso povo e com o conjunto da sociedade. Encaixado na busca incessante da construção de uma sociedade perfeita (terra sem mal) ou da vida plena (teko kavi). Sob formas próprias de representação, administração e propriedade do nosso extenso território" (Pacto de Unidad, 2006. Tradução livre).

Para as organizações indígenas a autonomia é uma forma de garantir a unidade dos povos indígenas, cada povo em seu interior, e também uma forma de garantir a unidade dos povos indígenas da Bolívia. Os movimentos também apontam a autonomia como uma verticalização do Estado, reestruturado de baixo para cima, uma experiência política e cultural de envolvimento e participação política da comunidade.

A cumbre define os elementos que caracterizariam uma autonomia: a) população culturalmente diferenciada, sendo os elementos dessa diferença características tais quais, idioma, cultura, história, b) existência de normas próprias e/ou de usos e costumes de acordo com a cultura, c) administração e autoridades próprias com poder de decisão e com controle e gestão sobre o território, a terra e os recursos naturais.

As autonomias respeitam os valores da unidade, subsidiariedade e solidariedade. Um dos desafios e dificuldades repousa no fato que a autonomia requer transferência de competências do Estado para as autonomias - essa descentralização do processo decisório muitas vezes não é de interesse nem de setores do governo, nem de setores que na prática tinham predomínio em certos espaços em que a participação política local continha certos vazios.

As primeiras propostas apontavam três enfoques para o tema: a) a reestruturação da atual divisão política administrativa da Bolívia, os limites de regiões e departamentos poderiam varias de acordo com o espaço das nações indígenas em regiões contínuas, o que na prática poderia ser interpretada como uma proposta que eliminaria os departamentos, b) o reconhecimento dos territórios indígenas de forma independente, como outra unidade autônoma, os departamentos continuariam a existir mas agora com autonomias, c) ou ainda, a coexistência entre diferentes unidades autônomas, coexistência de departamentos e municípios indígenas, uma reorganização dos territórios indígenas em distritos, municípios e entidades territoriais indígenas.

Faz parte de outra polêmica a possibilidade de veto ou não com relação aos projetos que atinjam direta ou indiretamente o espaço e a população das autonomias. Os 
receios giram em torno de que não havendo veto, a parte interessada no projeto não se comprometa a fundo com o processo de informação e negociação com as comunidades, enquanto, o mecanismo de veto provoca receio quanto ao seu uso indiscriminado como mecanismo de barganha ou boicote. Mesmo dentro das movimentos há discordâncias, as organizações sociais urbanas defendem que os recursos devem estar nas mãos do Estado. Daí decorre o debate se os recursos naturais seriam dos povos indígenas, ou se são de posse exclusiva do Estado ou ainda de ambos.

Como aponta Schavelzon, havia uma distancia dentro do Pacto de Unidade a respeito da autonomia indígena:

Las tensiones entre las organizaciones indígenas y campesinas tenían que ver directamente con el rumbo del proyecto de Estado Plurinacional. El mismo era el marco de un proyecto que iba acompañado de medidas que los campesinos y colonizadores parecían no acompañar o, en algunos casos, rechazaban explícitamente. Durante la Asamblea, las organizaciones indígenas cidob y conamaq, se quejaban de la falta de acompañamiento por parte de la otra mitad del Pacto de Unidad en reivindicaciones que para ellos eran partes fundamentales del proyecto de Estado Plurinacional, como la autonomía indígena, la representación directa, el reconocimiento de la propiedad colectiva, etc. (2013: 95)

\subsubsection{Plurinacionalidade e as organizações indígenas}

Também as lideranças da CONAMAQ defendem por sua vez o pioneirismo da demanda de uma nova constituição através de uma Assembleia Constituinte fundacional, soberana e inclusiva. Eles entendem a plurinacionalidade como a característica do Estado, necessária para o "respeito aos povos indígenas e nações originárias, dentro de um marco intercultural para a autodeterminação dos povos“. Implícito ao termo autodeterminação, com pouco sentido na jurisprudência interna ao Estado, se constrói, internalizando essa normatividade - estratégias de autonomia. A CONAMAQ constrói paralelos ideológicos embasando suas demandas políticas culturalmente, chamam a base da sua cosmovisão, valores e princípios como a busca da Suma Qamaña ${ }^{54}$, um paradigma em que se busca harmonia entre o material e o espiritual dentro da estrutura social do ayllus onde se busca a complementariedade do individual e do coletivo. Dessa forma querem contrastar e refletir sobre as características da política atual a partir de alteridades. Para a CONAMAQ o Estado

${ }^{54}$ Valor aimará resgatado pelo Movimento Katarista e que é retomado pela Constituinte, norteando enquanto princípio outras demandas indígenas. Traduzido como "Vivir bien ou Bien Vivir ou ainda Convivir Bien". Para ver as diferentes interpretações do termo: http://systemicalternatives.org/2014/07/31/apuntes-para-eldebate-buen-vivir-vivir-bien/. Acessado última vez dezembro de 2014. 
Plurinacional seria o Estado da Suma Qamaña que se caracteriza pelo consenso iyawsawi, ayawnispa - fundamento de uma elevada compreensão e consciência moral que permite entrar em acordo, apoiado por um sentido e uma prática de irmandade, o que seriam também a base para uma verdadeira democracia do ponto de vista da perspectiva política aimará.

Ademais depois do marco de uma nova legislação internacional sobre o assunto se teria uma necessidade de um processo de reconstituição que requereria um novo paradigma do Estado e não só uma adoção de marco regulatórios em um Estado tradicional, em que sistemas ancestrais façam parte reconhecidamente das instituições sociais e políticas, assim como o respeito aos seus modelos de desenvolvimento próprio baseado em valores tais quais de reciprocidade e respeito ao meio ambiente. E essa posição é seguida por todos os outros movimentos indígenas bolivianos, enquanto as organizações de cunho mais sindical e campesino a respeitam e enfocam na nacionalização dos recursos e na afirmação nacional frente ao imperialismo na esfera internacional. Os seus direitos coletivos em relação a terra e território também seriam a interpretação de cunho mais social para a ideia de Plurinacionalidade.

O tema das autonomias é multidimensional e implica normatização de aspectos jurídicos, políticos, sociais, ambientais. Uma preocupação inicial seria preparar o Estado para desconstruir a centralização desses aspectos. Esse é um projeto intercultural na medida que é necessário um encontro de outras lógicas e outras gestões. Do outro lado, há projetos de gestão desses espaços, de economias que possuem dinâmicas e especificidades que não podem ser normatizadas a priori, pelo Estado. Ainda assim devem ser previstas e refletidas sobre o contato dos diferentes interesses sobre esses espaços não uniformizados nacionalmente. O tema da auto-gestão e do auto-governo e das diferentes experiências nas terras baixas seria sequência importante deste trabalho.

\subsection{A constituinte se inicia em Sucre}

Em agosto de 2006 é dado início a Assembleia Nacional Constituinte (ANC) em Sucre $^{55}$. A cidade é capital jurídica do país e está situada no intermédio entre a região andina e a região do chaco - porta para a amazônia boliviana. Ao longo do ano de 2006

\footnotetext{
${ }^{55}$ Considerada capital jurídica, abriga diversos prédios do judiciário. Na Guerra Civil de 1898, La Paz e Sucre disputaram a capitalidade do país em um contexto de decadência econômica da região de Potosí e Sucre e maior enriquecimento da região de La Paz. Parte das decisões da Lei de Convocatória a cidade foi escolhida como sede da AC por ser considerada um local mais neutro, ou por certo prevendo a instabilidade das ruas de La Paz.
} 
não se negocia nada além das regras do debate, o clima é de animosidade. No começo de setembro em um plenária às 4 da madrugada, os constituintes tentam aprovar as regras do debate a partir de uma proposta que havia sido objeto de consenso. No entanto, os constituintes do PODEMOS iniciam um momento de tensão, pois não concordam com a votação e com a proposta. Eles começam a hostilizar a presidente da Constituinte entre outros assembleístas, a gritar e golpear as mesas. Román Loayza (MAS), subiu em um púlpito para tentar acalmar os ânimos, e em um passo em falso, ele cai de cabeça no fosso do teatro, entrando em coma em seguida. Treze dias depois são aprovadas 18 normas transitórias de funcionamento da ANC, como forma de adiantar as regras do debate ainda não consensualizadas, sai o decreto para que os constituintes colham propostas dos setores e eleitores que os apoiam. No final do mês se aprova por maioria absoluta apenas o primeiro artigo das regras de debate em que se declara originária a $\mathrm{AC}$, o PODEMOS se opõem posteriormente. $\mathrm{O}$ debate sobre uma AC originária se ligava a maioria de $2 / 3$ - qualificada ou a maioria simples. Ao final do ano a $\mathrm{AC}$ está com a imagem desgastada, a associação do processo constituinte às velhas instituições políticas é inevitável. Considera-se delegar a decisão a um referendo, o MAS pensa ceder a favor da governabilidade o que encontra oposição do CSUTCB e outros movimentos.

\subsubsection{Os posicionamentos do movimento indígena frente à $\mathrm{AC}$}

Enquanto a congregação de movimentos sindicais, o CSUTCB, demonstrava de forma bastante influente e próxima ao partido do governo, sua insatisfação com as negociações, os movimentos indígenas, a depender da organização, também tentavam pressionar o partido, o governo e a assembleia, mas tinham uma posição de preservar uma autonomia política. Durante a $\mathrm{AC}$ o $\mathrm{CIDOB}$ esteve bastante próximo dos constituintes do MAS e assim, também fez parte de conversações próximas ao governo, tentando articular estratégias e apoiando algumas decisões do governo, enquanto outras organizações sociais se tinham a liberdade de criticar. Nesse momento, o CIDOB ficou conhecido por ter uma posição bastante aliada ao governo, e recebeu críticas de outras organizações e até de comunidades vinculadas à confederação, como foi o caso da APG que decidiu em alguns momentos se manifestar ${ }^{56}$ de forma autônoma e crítica fora da CIDOB. No entanto, para os dirigentes da CIDOB seu posicionamento não era

56 Esse arranjo entre as duas instituições afirma não rupturas mas formatos políticos que tem espaços para maior autonomia. 
exatamente uma simples vinculação política. Para acompanhar as negociações de perto, a ponto de promover uma consultoria técnica já que a Confederação possui larga experiência jurídica e política com formulações legislativas na área dos Direitos Indígenas $^{57}$. A posição da CIDOB era um compromisso de participar do processo e ver transformadas as demandas em legislação de fato contundente a essas demandas, um compromisso com o "processo de mudança" e não com figuras políticas (CIDOB, 2006). Após a AC a CIDOB voltará a ter posições contundentes e críticas frente ao governo, e sofrerá com críticas de setores aliados ao governo que declaravam a sua instabilidade de posições, e com isso poderiam agora ter sido comprados por setores conservadores de Santa Cruz, como o poderoso Comitê Cívico ${ }^{58}$. Esse senso comum que a mídia e declarações do governo e do MAS ajudaram a colaboram com a polarização territorial do país, não é plural e autônoma, e não reflete a posição do CIDOB de ter compromisso com as unidades menores que eles representam. A estratégia do CIDOB de conquistar certo protagonismo na colaboração indígena técnica na AC dá uma forte projeção as organizações indígenas orientes, antes bastante invisibilizadas, e tal protagonismo traz também mais cor ao discurso de plurinacionalidade.

Entre outras posições críticas com relação às negociações das regras, em setembro a Assembleia do Povo Guarani publicamente ${ }^{59}$ rechaça o movimento de pressão por um votação de 2/3. Por meio de uma "resolução" da APG torna público um documento que reafirma as históricas demandas das terras baixas pela realização de uma AC, com o objetivo de um novo Estado Plurinacional. E ainda, que: "os partidos políticos tradicionais foram derrotados em outubro de 2003 e tirados do governo pelas organizações sociais mobilizadas com o objetivo de concretizar uma AC com participação real de nossos povos."

57 O CIDOB comparada as organizações tem um trabalho forte com enfoque em princípios do direito indígena, por conta da forte interlocução com organizações internacionais. Além de contar com uma organização jurídica trabalhando em simbiose com ela, a CEJIS.

58 No período em que a Marcha se aproxima de La Paz, no dia 24 de novembro, o PODEMOS ameaça adotar uma postura de desobediência civil contra o artigo $71 \mathrm{e} \mathrm{em} \mathrm{desacordo} \mathrm{a} \mathrm{pressão} \mathrm{indígena} \mathrm{sobre}$ o Senado. Carlos Dabdoud, ex candidato a vice-presidente pela UN e fundador do "movimento" Nação Camba, se solidariza com os grevistas constituintes e ameaça declarar Santa Cruz de fato autônoma se não se respeita os dois terços na $\mathrm{AC}$, os prefeitos de oposição e a propriedade privada agrária no oriente boliviano. O constituinte Félix Cárdenas ( $\mathrm{CN}$ - Patria Insurgente) por sua vez declara que as mudanças continuarão e o povo "deve acostumar-se a ver oligarcas em greve de fome", foram 15 constituintes em greve de fome - acumulando assim as funções de protesto e de compromisso na feitura da Constituição concomitantemente.

59 Resolução da APG no tema da plurinacionalidade:

http://www.constituyentesoberana.org/3/propuestas/osio/apg-resolucion-plurinacional.html 
A APG acusa a representação de direita de serem pequenos grupos de poder pela manutenção de certas relações de dominação. E lamenta que tais partidos tenham conseguido representação na $\mathrm{AC}$, de forma a se articular como pequenas agrupações cidadãs de forma a travar o curso de uma mudança - na qual a Bolívia se tornaria mais inclusiva, participativa e solidária, e cujo marco e início se daria por uma nova constituição. As autonomias departamentais apareceriam como uma dessas demandas cidadãs supostamente legitimas que mascaram a tentativa de manter suas estruturas de poder e travar mudanças profundas seja em âmbito nacional ou em seus espaços particulares. E é pela ideia de uma mudança que traga um aprofundamento de uma "verdadeira democracia" através de um processo com a participação real e efetiva dos povos indígenas, que os guaranis rechaçam os $2 / 3$ que esse sistema "só beneficiaria aos interesses mesquinhos dos partidos e agrupações cidadãs". O povo Guarani era favorável a um sistema de votação por maioria absoluta para que as discussões não fossem travadas por alguns poucos em detrimento "das maiorias" e com a aprovação do texto final por $2 / 3$ como previa a LECAC.

No entanto a luta indígena não se concentra toda no processo da $\mathrm{AC}$, em setembro de 2006 começa a ser organizada uma marcha rumo ao Senado. No final de outubro tem início que sai novamente do oriente rumo a La Paz, ela alcança o número de 2000 protestantes, e tem como objetivo pressionar o Senado para aprovação da "Lei de Recondução Comunitária da Reforma Agrária" já aprovada na Câmara dos Deputados e que asseguraria a recuperação de territórios ocupados por latifundiários. A CIDOB pede o fechamento do Senado frente a decisão por parte dos partidos de oposição de não assistir as sessões e bloquear as mudanças na Lei do Instituto Nacional de Reforma Agraria (INRA), A Marcha vai ganhando adeptos a medida que avança rumo a capital. O CSUTCB - dirigida por Ávalos - deputado do MAS também organiza marcha que se articula à Marcha do Oriente. CONAMAQ também apoia a marcha e solicita ao presidente do congresso e ao vice-presidente Garcia Linera que convoquem uma sessão extraordinária do congresso para tratar das mudanças da Lei. Durante essa mobilização foi lida uma lista de personagens políticos vinculados ao latifúndio, entre eles Walter Guiteras, senador do PODEMOS. Respondendo a críticas de empresários, as lideranças declararam que denunciar o latifúndio e citando nomes não é estigmatizar. Junto a tais denúncias se soma outras tais quais a existência de guaranis que vivem em condições de escravidão a serviço de alguns agropecuários ou latifundiários. O MAS 
oficialmente 23 dias depois da passeata apoia a demanda indígena e provoca, com moderação: "respeitará as terras produtivas, mas não o latifúndio".

Apesar das energias concentradas ao redor da ANC, a marcha conseguiu uma expressiva cobertura da mídia, muito provavelmente, pelo tipo de protesto - o qual exige um sacrifício por parte dos que se mobilizam em uma esgotante e longa cruzada com 70 baixas e três mortes em um mês de caminhada. O que desviou a atenção das infindas discussões e polarizações na plenária para um direito indígena pontual. Em um momento em que as manifestações externas giravam em boa parte em torno das autonomias departamentais, a marcha trouxe a baila do debate outra questão muito mais velada pelo setor conservador da região da meia-lua situada no oriente boliviano, o latifúndio ilustrada por uma problemática real, ligada não apenas ao seu conceito de improdutividade, mas também da realidade afetada ao redor: os indígenas. Romero (MAS) vai além ao falar das implicações da economia de grandes terras ao redor das pequenas comunidades no campo, e da questão da terra indígena no oriente nem sempre baseada na agricultura, e aponta na ocasião "o princípio de que a terra é de quem trabalha nela não é suficiente. É preciso redesenhar uma estrutura agrária que responda a um modelo de desenvolvimento integrador" (Albó, 2007).

\subsubsection{As organizações do lado de fora da AC}

Em Sucre, desde o início da AC, em diferentes momentos se fortalece a presença indígena do lado de fora da Constituinte, como forma simbólica de presença, participação e pressão. Em meados de novembro a APG e a CONAMAQ se organizam fazem vigílias pelos seus direitos e pressionando também o MAS e suas promessas junto ao movimento. É nesse cenário que as organizações rechaçam o recurso do PODEMOS que alegava inconstitucionalidade de uma Assembleia originária. Em 22 de novembro, com o final do ano e o cenário de indefinições, acontece um momento de maior pressão e tentativa de articulação para prosseguimentos dos trabalhos, o Pacto de Unidad anuncia que retomará a vigília em frente a Constituinte. Duas manifestações indígenas acontecem de forma complementar, enquanto a Marcha chega a La Paz para pressionar o Senado, há diferentes grupos que revezam, chegam e reforçam a vigília junto a Assembleia. No dia 30 de novembro a Marcha do Oriente chega a La Paz, e campesinos e povos originários da região de Chuquisaca chegam a Sucre, CONAMAQ e CSUTCB e Confederação de Colonizadores anunciam a presença de 150 de seus membros que permanecerão em vigília. Em ambas as capitais o que se vê é o desfile de 
bandeiras - wiphalas ${ }^{60}$ e muitas bandeiras da Bolívia, passando por praças e alcançando os prédios oficiais. As duas manifestações se articulam e se reforçam, como uma ponte, que indica uma ligação, o que estava acontecendo em Sucre tinha relação com formulação de leis infraconstitucionais ${ }^{61}$ que estavam sendo aprovadas no Congresso em La Paz. De forma mútua uma marcha dava visibilidade a outra, no caso, a marcha que está em La Paz indicava a presença indígena lutando pelos direitos na CPE, e a vigília em Sucre sinalizava a continuidade política e jurídica dos direitos planteados na CPE, e revela as estratégias concatenadas de partidos, constituintes e setores conservadores e a característica participativa e vigilante do setor.

Os cívicos de Santa Cruz reagem e pedem ao presidente uma "cumbre" entre a Diretiva da Assembleia Constituinte, o Poder Executivo e os Cívicos de todo o país. Ignacio Mendoza, primeiro secretário da Diretiva e assembleísta do MAS, manifesta que segundo o Regulamento Interno aprovado a Assembleia é soberana. O Comitê Cívico como é possível ver pelo seu nome se autointitula não partidária, mas apenas cívica, como uma ampla organização de diversos setores da sociedade. Conduzem assim, todo um pensamento conservador regional, com elementos moderados: conservação dos valores da igreja, dos antigos valores já instituídos, da lei. A estrutura dos Comitês tem uma forte simbiose social, os Comitês Cívicos (CC) são liderados majoritariamente por donos de terras, mas há o Comitê Cìvico feminino que é constituído pelas esposas e ganha ressonância no mundo feminino em geral, e ainda há uma União Jovem, local dos filhos dos que são ligados ao CC, mais voluntariosa, e que foi responsabilizada pelas manifestações mais violentas em Santa Cruz. Os CC nascem como uma forma de liderança política e articulação local, em um ambiente que até então não havia eleições diretas para cargos políticos, tal qual governador do departamento. No entanto, em um momento de desgaste das representações políticas e partidárias ganham força ao mesmo tempo que permanecem sem se vincular diretamente as instituições políticas. O governo departamental tem uma forte simbiose com o CC, mas ironicamente não é algo declarado. O mesmo acontece com o PODEMOS, no entanto representantes do PODEMOS oriundos da meia-lua estão muito mais articulados com

60 Wiphalas são bandeiras de origem aymara, e que em algum momento para alguns grupos indígenas se tornou uma bandeira da causa indígena de toda a Bolívia. No entanto, como muitas culturas identificam a origem dessa bandeira com a cultura aymara, em variadas situações de protesto indígena não se vê a wiphala mas sim bandeiras da própria comunidade ou dos povos do oriente.

61 Marca a percepção indígena de que suas demandas teriam um avanço na CPE, mas que a luta seguiria em momentos de confecção de lei infraconstitucional. 
os CC. Essa clivagem dentro dos partidos causou ao longo do tempo períodos de maior proximidade e até ruptura entre as duas organizações que são as oposições mais expressivas ao governo de Evo Morales.

Há muitas variações de discursos, todos ligados ao CC. O que se percebe é que são várias instituições sociais todas bastante articuladas (famílias, advogado, donos de terras) que assumem discursos distintos de acordo com a estratégia (micro) políticas, tendo uma presidência que articula vários níveis dessa política regional, e que divulga uma imagem não de política regional, mas de identidade regional. Em Santa Cruz as articulações são muito próximas, principalmente no marco da CPE, ao mesmo tempo que uma organização de Direitos Humanos de Santa Cruz se apresenta neutra às disputas políticas, defendendo e enfatizando o processual democrático, a insegurança jurídica que o governo coloca o direito, em certas situações da ANC, ao mesmo tempo em que é possível perceber a forte interlocução entre esses membros e outros membros do CC. A defesa com argumentos jurídicos sobre determinado status quo do Estado ou dos direitos individuais, é tida simplesmente como uma defesa neutra, moralmente superior às tentativas políticas de fazer mudanças nesse arcabouço político-jurídico.

É em dezembro, externamente a Constituinte, que acontece um grande encontro, que marca o ápice conflitivo das partes, Estado, movimento indígena e Cívicos ${ }^{62}$ se reúnem no colégio Nacional Junín. Estão presentes presidente e vice-presidente da

\footnotetext{
${ }^{62}$ Situada em Santa Cruz, a CIDOB é minoria e está em fogo cruzado, na luta de Santa Cruz com o altiplano. Em dezembro, próximo ao período de recesso da ANC, depois de diversos posicionamentos oficiais. A Confederação com tom de denúncia divulga o Manifesto pela Unidade da Bolívia, uma declaração oficial sobre o recente histórico de assédio que a organização e as populações indígenas estavam sofrendo na região. Durante a Marcha à La Paz daquele ano, segundo a denúncia, o Comitê Cívico e a Prefeitura de Santa Cruz teriam pago "pseudo dirigentes" indígenas que tentaram tomar a sede da CIDOB alegando serem os novos dirigentes, ao passo que não reconheciam mais a presidência da organização, aproveitando esvaziamento físico do corpo da Confederação por conta da marcha, e se utilizando de um discurso de ação política direta de reclame, e uma reivindicação de legitimidade, ou não reconhecimento da autoridade. Além da estratégia falsa e teatral, o setor conservador parecia querer deturpar alguns dos seus mecanismos populares de protestos como ação política. A CIDOB declara seu repúdio a tal fato que "contradiz qualquer atitude democrática", e entende que as ações dos Comitês Cívicos (CC) e prefeituras da "meia-lua", especial ênfase é dada a Santa Cruz, são atos antidemocráticos, sediciosos e vândalos, que tentam dividir o país, ignorando e violentando instituições indígenas. $\mathrm{O}$ manifesto descreve também o ataque aos escritórios, as ameaças com linchamento de dirigentes e de militantes de base. Os ataques ocorrem em cinco cidades do interior de Santa Cruz, material, veículos, e a integridade física de pessoas foram ameaças, e relata que em um Cristo Redentor situado em uma avenida da cidade foi colocado uma forca para os traidores, e que em toda a região havia a impossibilidade de expressar a sua liberdade de consciência contra a reação imediata e gratuita que os assediavam chamando os de colla ${ }^{62}$, indígena traidor, anticruceño, para não falar também das pichações, programas de rádios e cartazes pela cidade, de tom racista generalizado. Como resposta ao documento da CIDOB o governo enviou uma comissão encabeçada por dois ministros conduzidos pelo defensor público com o objetivo de pacificar a região. http://www.constituyentesoberana.org/info/?q=cidob-unidad Último acesso em janeiro de 2011.
} 
República, a diretiva da Constituinte, presidentes de sete comitês cívicos e lideranças de organizações sociais campesinas indígenas originárias. Depois de seis horas de diálogo, com momentos tensos, a presidência propõe aos cívicos interromperem as medidas de pressão e a diretiva suspenderia as sessões - o que viria na esteira do recesso do final de ano. E assim manter-se-ia o diálogo com os cívicos, de forma que Silvia Lazarte fica comprometida a analisar as propostas - por sua vez vários diretivos exigem das partes ali presentes que eles deixassem a AC trabalhar de forma autônoma. No entanto, os cívicos da meia-lua anunciam de forma unilateral, logo separatista, cinco dias depois a criação de uma região autônoma.

No período de 6 a 9 de dezembro de 2006 em Cochabamba, é organizada uma Cumbre Social por la Integración de los Pueblos com variadas organizações sociais, ainda sob o marco da articulação do Pacto de Unidad, retomando um ano de encontro, quando no final de 2005 a "Cumbre Social" havia se reunido para em um processo decisório unificarem suas demandas na forma de proposta de texto constitucional. $\mathrm{O}$ tom que marca a reunião é o do antineoliberalismo inseridos no marco da Campanha Continental contra a ALCA, mas também evidencia que a integração do país não poderá ser consolidada sem o respeito a diversidade. A ideia de soberania e de integração solidária dos povos está presente em um cunho anticapitalista, mas nesse momento também essas ideias são vivenciadas como afirmação da particularidades desses coletivos frente a um sistema hegemônico, que inclui outros sistemas que não só o econômico.

O dia 15 de dezembro foi também o dia em que o Comitê Cívico e a Prefeitura convocaram um "cabildo" em Santa Cruz. ${ }^{63}$ Para as organizações indígenas e sociais o cabildo era um medida inconstitucional e antidemocrática, pois não era permitido a participação livre de nenhum desses setores sociais. Por sua vez, a CIDOB em seu manifesto convoca a não participação ao cabildo, de forma a evidenciar que o rito em questão, na aparência, simula um mecanismo de organização e participação democrática, no entanto se atribui uma representação que não possuem. Ao passo que no conjunto de todo o país havia um movimento para que o desejo da maioria fosse representado, em Santa Cruz se clamava pela participação minoritária da região como

63 Foi o nome dado a uma forma de mobilização civil em que se pudesse coletar apoio e legitimar as posições de Santa Cruz e das outras regiões da meia-lua. http://www.constituyentesoberana.org/info/?q=cabildo-sedicion 
representativa, declarando se contra a força oligárquica regionalista que estavam favorecendo o fracionamento do país.

Nesse ponto, a CIDOB defende a posição indígena a favor da integridade nacional resgatando a memória de longa duração e de uma identidade compartilhada e solidária através do marco da colonização, em pronunciamento dizem que é um legados dos seus antepassados lutar pela unidade e pela integridade nacional. Ironicamente, a Bolívia como Estado e como nação sustentou, devido às ações dos indígenas, que se refundaria o conceito de nacional, em um crivo ético-cultural em que a pluralidade se insere como valor simétrico de coexistência. E nesse ponto os indígenas afirmam as bases dessa integridade e se distanciam de possíveis especulações de que seriam separatistas: "todas as terras e recursos do oriente, do chaco e da amazônia nos pertencem e é a nós que corresponde determinar o uso, distribuição e o aproveitamento das nossas terras e dos recursos naturais" (Manifesto pela Unidade da Bolívia, dezembro de $2006^{64}$ ). Ao fim e ao cabo, a demanda por autonomia departamental, que vem à baila roubando a atenção da demanda original por autonomia indígena e trazendo um elemento que ajuda a confundir um debate que quer-se estabelecer. Ao longo da AC o setor conservador da meia-lua se mostrou com ímpeto separatista, quando historicamente o perigo separatista recaía sobre o "outro" nacional, os indígenas.

\subsubsection{Ações do governo Evo Morales para a região Amazônica}

A Assembleia entra em recesso no final de 2006. Também paralela a AC o governo de Evo como forma de se fazer presente em uma região que historicamente o Estado esteve ausente lança no início do ano um plano estratégico de desenvolvimento para a Amazônia. Uma forma também de ir ao encontro das demandas dos setores conservadores que reclamavam da histórica falta de investimento federal na região. A "Unidad de Desarrollo Integral de la Amazonía" representa a refundação territorial do país, na visão de Evo Morales em dois sentidos, pois agrega o discurso de uma refundação econômica que recupera o controle dos recursos naturais através de uma política que nacionaliza o gerenciamento dessas atividades e outro sentido da refundação territorial seria a integração nacional através da infraestrutura a ser construída na região que conectaria e facilitaria acessos. A região Amazônica cumpre

64 Documento elaborado pela CIDOB meio aos atos dos setores conservadores da meia-lua antidemocraticos, violentos e que iam em direção a divisão do país. 
papel estratégico, pois abriga o polo de extração do que seria a nova onda nacional de recursos naturais: o gás e o petróleo

A data coincide com o lançamento do Programa de Aceleramento do Crescimento - PAC do governo brasileiro, também lançado em janeiro de 2007, e que também vinculava a parte amazônica do país com o objetivo de melhorar a logística e a infraestrutura que conecta o país e a região. O dinheiro do BNDES estaria relacionado ao plano boliviano, ao passo que há o marco regional do PAC, a "Iniciativa para a Integração da Infraestrutura Regional Sul Americana" - IIRSA.

A princípio, a nova instituição coloca o debate público, as aspirações e a participação da sociedade civil no centro do plano. Remete a importância de um plano de desenvolvimento consciente e com uma integração da região ao conjunto nacional. Fala de populações em extrema vulnerabilidade, como é o caso de pequenas populações indígenas sem largo contato com demais populações da região, e acaba por fazer uma conexão com os povos indígenas amazônicos em geral, como se a "Unidad" cumprisse um papel dentro das reivindicações desses povos, dando dimensão a sua história e a identidade boliviana como um todo. Ao mesmo tempo que conecta a demanda por nacionalização e a redistribuição dos ganhos para todo o país, projeta a importância dos povos amazônicos, garantindo proteção a categoria dos vulneráveis. No entanto, mais à frente esse projeto entrará em conflito, no que diz respeito à reivindicação por autonomia política, e soberania dentro do espaço das suas terras e a função dos projetos de desenvolvimento do governo. Pois ligado a esse Plano se encontrará o projeto de estrada que cruzaria o território mojeño TIPNIS. Um conflito que chegará ao seu ápice apenas em 2011, conflito esse pesquisado por Moraes (2014). O desafio será a capacidade do Estado de dialogar e respeitar os mecanismo de autonomia indígena através da consulta prévia.

\subsubsection{Comissão "Visión de País"}

O cronograma da AC recomeça então em fevereiro de 2007 e prevê seu término para agosto. Entre final de fevereiro e março se inicia as discussões em torno da Comissão "Visões de País". As primeiras definições que dariam o caráter do Estado serviriam de linha condutora para o desenvolvimento dos artigos de outras comissões. Em um primeiro momento o Estado e seus ministérios apresentam as informações atualizadas da situação boliviana em vários temas. Na primeira semana de março os partidos debatem publicamente suas visões de país, o MOP, AS, ASP, MCSFA e 
sobretudo o MAS apoiam o Estado plurinacional, comunitário e solidário. O MAS enfatiza a sua convicção de fundar um novo país a partir da Assembleia e da redação de uma nova Constituição fundacional. A outra posição defendida pelo MNR-A3, APB (Santa Cruz), PODEMOS e o único constituinte do MIR enfatizam a autonomia departamental. O MNR-A3 recusa toda e qualquer propriedade comunitária, Jorge Lazarte (UN) afirma que o termo "nações originárias" corrompe a unidade nacional - a defesa de direitos coletivos e a possibilidade de existência de outras culturas é colocada em contraposição a unidade nacional e a integridade do Estado. Por essa lógica a descentralização do poder só poderia ser realizada dentro das instituições já existentes, as mesmas identificadas como sendo viciadas e não representativas, travando novas possibilidades de formatação de poder, e de formatações interculturais dessas novas instituições e descentralizações. Guillermo Richter estabelece uma série de dúvidas sobre um Estado Plurinacional. Hormando Vaca Díaz (AAI) critica a atitude do MAS frente a Igreja - já que para abraçar várias culturas esse novo Estado teria que retirar o vínculo exclusivamente Católico da lista de adjetivos do Estado Boliviano, o argumento da desvinculação do Estado com a Igreja Católica serviu como forte argumento na campanha contra a CPE em Santa Cruz, sendo interpretado de forma radical como uma desvinculação da sociedade com valores éticos e morais cristãos. No entanto, mesmo em meio à oposição se encontra consenso sobre municípios indígenas. Uma forma hibridizada, apropriada e adaptada ao sistema convencional - os municípios indígenas gozariam de reconhecimento político e espaço para uma autonomia indígena institucionalmente híbrida, sendo que as atribuições do espaço da cidade ficam em aberto como em qualquer outro plano urbanístico.

No temas econômicos havia maior consenso com relação ao papel do Estado, o MNR e o UN defendiam certo ação do estado na economia e o controle dos recursos naturais e também uma economia social de mercado. O UN, assim como o MAS era favorável ao fortalecimento de empresas populares. Conseguir 2/3 para uma maior intervenção do Estado em atividades extrativas produtivas não seria difícil. A disputa, entretanto, desembocaria inevitavelmente em como seriam redistribuídos territorialmente esses dividendos.

Um fato curioso é que durante as plenárias da Comissão de Visão de País contou-se com diferentes formas de apresentação e defesa dos argumentos, desde os discursos tradicionais, aos pedagógicos, objetivos como também os sofisticados power 
points, com dados e referência a princípios jurídicos presente fortemente na fala do PODEMOS. A proposta do PODEMOS tinha como síntese do seu programa uma estrela, em que suas seis pontas representavam os seis pontos principais: direitos, novo modelo econômico, autonomias e descentralização, justiça despolitizada e um novo modelo político - uma reforma inspirada em modelos de eficiência da administração pública. Mas a novidade esteve presente na pluriculturalidade em forma e conteúdo, na apresentação do MAS, com partes do texto proferidos em quechua, aymara, guarani, besiro, moxenho e espanhol e ao final um ritual com uma espécie de incensário com menta silvestre.

Cinco dias depois do início das apresentações em março surge novamente a polêmica demanda sucrense pela "capitalía plena"65. A disputa pelo poder, transferida pela disputa entre regiões com a possibilidade de afirmarem mais autonomia e poder, se transferiu para a AC por meio da simbólica definição de uma capital nacional mais influenciada por um recanto ou outro. Em um momento em que todos os lados estavam discutindo autonomias, a AC fica largamente e ironicamente marcada pela questão da centralidade de uma sede do poder. A questão levantada pela oposição ironicamente provoca uma ruptura dentro do PODEMOS, partido o qual os cívicos se articulavam para exercer oposição. A bancada do PODEMOS de La Paz pede que se respeite a cidade como sede do governo. E ao fim das apresentações da Visão de País uma grande marcha toma a praça de Sucre com a demanda pela plena capital. A mídia local descreve de maneira homérica a mobilização como a maior dos últimos tempos, de fato a mobilização era bastante articulada com o Comitê Cívico e a prefeitura a seu favor, a marcha conta com discurso do reitor da Universidade da cidade. No final de março seria o momento do CC de Santa Cruz declarar apoio a demanda por plena capital em Sucre.

Após as apresentações sobre a "Visão de País" os constituintes, divididos em comissões embarcam por um mês para visitar as diversas regiões, trocar e recolher propostas durante os "Encontros Territoriais", parte da comissão permanecia em Sucre e a parte que corria o país tinha a responsabilidade de enviar as propostas coletadas e sistematizadas. Essa estratégia dos Encontros tem como objetivo também aproximar a população da $\mathrm{AC}$ e dos temas a ela concernentes, assim como forma de restituir a

\footnotetext{
${ }^{65}$ A disputa entre cidades pela sede da capital política e juridical não é algo tão raro e já ocorreu na Bolívia durante a Guerra Civil no final do século, quando Sucre então polo econômico entrando em decadencia perde a sede do governo pra La Paz. Duas elites regionais em disputa, assim como ocorreu durante a AC.
} 
legitimidade e a seriedade ao processo, além de incentivar os constituintes a focarem o seu trabalho nas demandas daqueles que representam. Durante os encontros se ouviria diversas organizações, mas também percepções de pessoas comuns, no entanto, na opinião de Gamboa (2009), havia um cronograma demasiado apertado para ouvir e coletar proposta, e que tal evento tentava converter seu processo em performance de um encontro magno com o desejo do povo, interconectando regiões e ouvindo um conjunto variado de demandas. Para Gamboa se tratava de um subterfúgio político, assim seriam as ações políticas repletas de performances de encontro que também visam compartilhar sentidos de coletividade, o convite a participação.

No final de maio, os partidos e demais representações minoritárias da AC se dividiam entre dois informes da comissão, um da "esquerda" e outro da "direita". Externamente a AC no dia 22 de maio o Pacto de Unidad se reencontra, a Confederação de Colonizadores e Campesinos, as Bartolinas Sisa, a APG e o CONAMAQ juntam forças para pressionar a incorporação do Estado Plurinacional e a autodeterminação dos povos e nações indígenas, originárias e campesinas e emitem declaração conjunta. Nesse mesmo momento os assembleístas do departamento de Chuquisaca formam uma diretiva para trabalhar o retorno dos poderes a Sucre.

No último dia de maio é aprovada por unanimidade o primeiro artigo da nova CPE: "Bolívia constitui-se como um Estado Unitário Social de Direito Plurinacional Comunitário, livre, independente, soberano, democrático, intercultural, descentralizado e com autonomias. Bolívia se funda na pluralidade e o pluralismo político, econômico, jurídico, cultural e linguístico, dentro de um processo integrador do país66. O consenso foi alcançado quando as negociações seguiram o caminho de imiscuir termos e princípios importantes para ambas as partes, tais quais: Estado de Direito, junto com Estado Social, Estado unitário contra o suposto perigo de separatismo ou traição dos povos indígenas, que na verdade demonstrou mais fervor nos grupos conservadores. Ao final, para ambos os lados a ideia de pluralismo soou no texto como garantia dos seus respectivos sistemas. No começo de junho em uma sessão agitada é aprovado o

66 O artigo primeiro da Constituição anterior dizia:

Artigo 1.

I. Bolívia, livre, independente, soberana, multiétnica e pluricultural constituída em República Unitária, adota para seu governo a forma democrática representativa e participativa, fundada na união e na solidariedade de todos os bolivianos.

II. É um Estado Social e Democrático de Direito que sustenta como valores superiores do seu ordenamento jurídico, a liberdade, a igualdade e a Justiça.

A constituição anterior é do ano de 1967, e sofreu reformas, inclusive no seu primeiro artigo, nos anos de 1994 e 2004, quando foi reconhecido constitucionalmente a pluralidade nacional. 
"informe por maioria" do MAS e o "informe de minoria" do $\mathrm{CN}$, e assim o informe mais engessado do PODEMOS era descartado. Jorge Lazarte não pôde votar por não ter formalizado a sua ligação com aquela comissão. O ponto é que com o voto de Jorge Lazarte o informe da oposição poderia ter empatado com o da CN. O PODEMOS paralisa seu trabalho, na redação de novos artigos a menos que seu informe seja incorporado na Comissão Visão de País. E ao paralisar essa comissão de certa forma paralizavam as outras, pois as definições acordados nessa comissão seriam usadas como base de princípio para outros artigos e comissões, a regularização das suas polêmicas levou a um clima de atraso e de trabalho sem ritmo a outras comissões. Pra além das definições do artigo 1, relativo ao caráter do Estado-Nação, os informes da Visão de País delimitavam o papel do Estado frente a direitos e garantias, frente a economia, ao uso de recursos, e a administração de terras públicas e claro, delimitaria sua nova estrutura - judiciário, legislativo e suas autarquias e a relação das suas unidades (departamento, município ${ }^{67}$ ) com o Estado.

Em 20 de julho mais de um milhão de pessoas se manifestam em El Alto contra a mudança da sede do Governo de La Paz para Sucre. Em 15 de agosto a Assembleia Constituinte retira de sua agenda o debate sobre as capitais da Bolívia, inicia-se assim distúrbios que impedem a continuidade dos trabalhos. Cinco dias depois da retirada do tema 10 estudantes se prendem em uma cruz na praça principal de Sucre, e outros 8 iniciam uma greve de fome pela plena capital.

A forte mobilização em Sucre formando uma campanha pela capital plena à cidade, afetou a Comissão de Autonomia. Mesmo que o artigo ao qual se referiria a capital do país, estivesse sendo discutido inicialmente na Comissão Visão de País. A presença de dirigentes cívicos e assembleístas do departamento de Chuquisaca e La Paz durante as sessões tornam-as ásperas - as acusações e reivindicações recaem sobre o centralismo de La Paz - o que poderia se traduzir ao poder hegemônico do governo Evo. Ou como se cunhava "o governo índio ${ }^{68}$ de La Paz". A autonomia, e no caso a autonomia departamental indicava uma estratégia de oposição ao governo. A autonomia como descentralização e horizontalização política estava cerceada por disputas

67 Nos textos dos informes é dada maior atenção à dinâmica dos munícipios, mais que dos departamentos. Uma forma não só de se furtar do tema das autonomias regionais, mas também de levar uma perspectiva de novos espaços políticos em que a política local se exerce de baixo pra cima, e não que compitam com certas definições da União tentando seu poder de influência a novos espaços de poder.

68 Na Bolívia o termo “índio” carrega conotação pejorativa. 
hegemônicas. Enquanto isso a plurinacionalidade continuava a ser o outro ponto de maior discussão, outra definição disputada enquanto um caminho para um clima de maior diversidade e inclusão era contraposto ao de antagonismos. O fato é que o movimento para trazer de volta a capital a Sucre, de forma plena, iniciou-se em um caráter isolado, fruto de uma posição de um constituinte e não era encarada como uma demanda com espaço e força para ser de fato discutida. No entanto, ganhou força e se tornou bandeira no momento de embate entre dois locais de poder antagônicos, o altiplano (ou o governo) e o oriente (base opositora). Assim a ideia alcançou maior solidez nos encontros regionais, momento em que surge com força o discurso da autonomia departamental como demanda e como estratégia mais eficiente de oposição. Os encontros regionais foi também uma oportunidade para as oposições regionais se articularem melhor. $\mathrm{O}$ impasse segue, polarização política bem refletida em sistema partidário.

Em julho, surge um acordo realizado intracomissões em que os assembleistas do MAS e aliados estariam dispostos a fazer uma nova votação de minoria e maioria dos informes da Comissão do País, se a oposição se comprometesse incorporarem sempre as autonomias indígenas nas perspectivas do trabalho da Comissão de Autonomias. As negociações parecem querer ceder sempre que se possa conseguir dar prioridade ao tema que se quer de fato priorizado. Essa é uma estratégia governista, para as organizações indígenas a partir do comprometimento com a ideia de Plurinacionalidade o tema das autonomias indígenas se vincularia como matéria de destaque para cumprimento desse novo status.

\subsection{Momentos finais da $\mathrm{AC}$}

Próxima a votação da CPE o clima é de insegurança, há dificuldade de acesso a ANC por parte dos assembleísta, assédio aos mesmos também em suas casas em toda a cidade. No dia 24 de novembro é aprovado o novo texto constitucional em uma escola militar em Sucre, em primeira instância a aprovação acontece diante da ausência da oposição em meio a distúrbios que deixam três mortos e 300 feridos. Esse evento de conflito e caos permanecerá sendo relacionado ao processo da ANC por longos meses, no entanto o clima de sítio também deixa o evento obscurecido em termos de compreender os fatos, motivações e ponderar de quem exatamente partiu os excessos, 
até entender que nem toda a manifestação popular ganha legitimidade em sentido mais amplo

Foi no final da $\mathrm{AC}$ que o conteúdo do que foi acordado veio à tona para a análise. Foi o momento de socialização do texto, para recuperar o sentido do processo constitucional no momento de sua aprovação. A ênfase foi dada no resultado palpável da CPE, mais serviços básicos para a população a partir da lógica de que os recursos naturais agora nas mãos do governo terão seus lucros convertido em mais serviços para a sociedade. Romero aponta três eixos de mudanças estruturais presentes no texto constitucional: o novo desenho do Estado, o reconhecimento das autonomias e o modelo do desenvolvimento econômico-social. Agora o Estado Plurinacional da Bolívia como começaria a ser chamado frequentemente depois de 2009 congregava em suas qualidades o comunitário, o descentralizado através das autonomias, unitário, social e descentralizado. Romero formula uma explicação ampla para o sentido de autonomia, compõem o Estado, governos subnacionais com instituições executivas regulativas e legislativas. Se utiliza ao fim um mesmo termo para acepções de ordem diferente, a distinção e confusão entre autonomia indígena e departamental é comum, em alguns momentos os departamentos abstraem o sentido de autarquia da união e recorrem a ideia de estatuto próprio como uma constituição política e jurídica própria. No entanto considerando que não eram plataformas concorrentes, mas ainda assim assuntos cada um em particular com suas polêmicas deixa-se para as leis infraconstitucionais posteriores os maiores detalhamentos das suas dinâmicas institucionais.

No ápice da discussão sobre a forma do Estado e as autonomias indígenas a falta de consenso faz surgir a possibilidade de colocar o tema em referendo e também cada autonomias se tornar objeto de referendo para a sua criação. A parte mais centralista do MAS temia a fragmentação dos país e dos departamentos, e consequentemente o aumento das pugnas regionais, a parte mais compromissada do MAS com as autonomias indígenas viam essa proposta com muito receio ao saber que era um tema de minoria sendo colocado em referendo popular. O MAS conversa com as organizações do Pacto, e segundo o presidente do CEJIS, as organizações esvaziariam aquele ritual político, caso desistissem de avançar no tema das autonomias indígenas. Romero que antes ocupou o mesmo cargo no CEJIS agora estava na posição de assembleista, ligado ao MAS, e numa posição de negociar pelo MAS, não mais de representar a CIDOB, ele buscava um acordo com os indígenas (Schavelzon, 2013: 183). Dentro do MAS havia duas posições 
diferentes, como aponta Schavelzon:

En el MAS, el proyecto de Constitución incluía una clara tensión entre dos perspectivas. De un lado, el desarrollo del proyecto plurinacional, con la autodeterminación para las autonomías indígenas; del otro, un proyecto nacional, de inspiración socialista, popular, convencido de la necesidad de utilizar el Estado como herramienta de intervención política en la economía, que buscaba frenar lo que entendía como ambiciones de una elite desplazada recientemente del poder y acantonada en Oriente (2013:193).

Se buscou, ao final, uma autonomia indígena que neutralizasse as autonomias departamentais na articulação do MAS. As organizações parte do Pacto de Unidad escreviam sua proposta de Autonomia que seria pleiteada através da VII Marcha. Ivan Égico, que fazia parte da equipe técnica da CIDOB questionava se o fato do MAS ter abraçado a causa do direito a autonomia não era uma estratégia de neutralizar a própria autonomia departamental. Assim, foi nesse momento que a ideia de autonomia indígena e de plurinacionalidade se mostraram claramente polissêmicos. Para Schavelzon:

Para algunos campesinos era simplemente consolidar el poder que ya tenían en el control de municipios por parte de sindicatos. Otros pueblos del Altiplano buscaban más bien dejar de lado la estructura municipal de alcaldes y desarrollar las propias formas comunitarias de gobierno, en algunos casos ya existentes, como parte de la estrategia de reconstitución de los territorios preexistentes a la colonia. En las tierras bajas, guarayos o yuracarés buscarían reforzar el autogobierno en las TCO entonces vigentes, en algunos casos con distintas autonomías en el marco de espacios multiétnicos más amplios. El debate de las autonomías indígenas de hecho había sido importante en los años anteriores a la llegada del mas al Gobierno, con propuestas que surgieron junto a marchas y encuentros entre organizaciones (cf. Rocha [2008], Valencia y Égido [2010], Molina, Vargas y Soruco [2008]). Había sin duda una conexión o reflejo de la discusión que se había producido en México, donde algunos pueblos habían desarrollado la propuesta, al igual que intelectuales marxistas, especialmente después de su participación en la elaboración de un régimen de autonomias para la costa atlántica nicaragüense, incluida en la Constitución sandinista de 1987. En el debate boliviano la autonomía gana espacio después de la Guerra del Agua de 2000. En esa oportunidad, la política boliviana discute la autogestión y formas políticas no estatales de luchar contra la injusticia y por la vida. En 2003, García Linera presentó una propuesta de autonomías indígenas, como sistema combinado con formas diferentes para territorios de tierras bajas, departamentos "mestizos" y el caso que le era más cercano en ese momento, de una gran nacionalidade aymara en el Altiplano con un avanzado esquema de autogobierno con instituciones propias y participación en todos los niveles del Gobierno central (ver García Linera [2005a]) (2013:163).

Enquanto Félix Patzi defendia que a autonomia indígena era uma demanda específica 
das comunidades indígenas, o sujeito coletivo relacionado ao Estado Plurinacional e detentor de direitos coletivos e com políticas coletivas eram os povos originário, indígena campesinos. O termo guarda o desafio de criar articular e criar políticas para coletividades distintas e não bem delineadas.

\subsubsection{A plurinacionalidade ampla}

Linera em outro momento fala de seis eixos importantes do texto constitucional seriam 1) os direitos, 2) a representação congressal, 3) a justiça - com seu pluralismo jurídico até o nível do Tribunal Constitucional por meio de representação direta da justiça indígena originária, 4) a educação - que delimita novos parâmetros linguísticos, 5) a institucionalidade democrática - reconhecendo a democracia comunitária, mecanismos de participação direta tal qual os referendos, e as formas de autogoverno indígenas para o exercício da autonomia indígena, 6) e a propriedade de terras em que ganham prioridade de distribuição terras fiscais como terras comunitárias.

O preâmbulo foi redigido através de algumas propostas na sua maior parte por representantes do MAS no momento da Comissão Visão de País e reaparecem para votação e junção de propostas na polêmica votação de Oruro, o texto também era um reflexo da posição da diretiva da Comissão da Visão de País. O interessante é que após todas as críticas posteriores ao texto, o preâmbulo não foi motivo de disputa e passou incólume pela concertação realizada em outubro de 2008 no Pacto Congressal que garante a continuação do processo constitucional rumo a sua aprovação por referendo popular. Dessa forma o prêambulo se mantém da seguinte maneira:

En tiempos inmemoriales se erigieron montañas, se desplazaron ríos, se formaron lagos. Nuestra amazonia, nuestro chaco, nuestro altiplano y nuestros llanos y valles se cubrieron de verdores y flores. Poblamos esta sagrada Madre Tierra con rostros diferentes, y comprendimos desde entonces la pluralidad vigente de todas las cosas y nuestra diversidad como seres y culturas. Así conformamos nuestros pueblos, y jamás comprendimos el racismo hasta que lo sufrimos desde los funestos tiempos de la colonia.

El pueblo boliviano, de composición plural, desde la profundidad de la historia, inspirado en las luchas del pasado, en la sublevación indígena anticolonial, en la independencia, en las luchas populares de liberación, en las marchas indígenas, sociales y sindicales, en las guerras del agua y de octubre, en las luchas por la tierra y territorio, y con la memoria de nuestros mártires, construimos un nuevo Estado. Un Estado basado en el respeto e igualdad entre todos, con 
principios de soberanía, dignidad, complementariedad, solidaridad, armonía y equidad en la distribución y redistribución del producto social, donde predomine la búsqueda del vivir bien; con respeto a la pluralidad económica, social, jurídica, política y cultural de los habitantes de esta tierra; en convivencia colectiva con acceso al agua, trabajo, educación, salud y vivienda para todos.

Dejamos en el pasado el Estado colonial, republicano y neoliberal. Asumimos el reto histórico de construir colectivamente el Estado Unitario Social de Derecho Plurinacional Comunitario, que integra y articula los propósitos de avanzar hacia una Bolivia democrática, productiva, portadora e inspiradora de la paz, comprometida con el desarrollo integral y con la libre determinación de los pueblos.

Nosotros, mujeres y hombres, a través de la Asamblea Constituyente y con el poder originario del pueblo, manifestamos nuestro compromiso con la unidad e integridad del país.

Cumpliendo el mandato de nuestros pueblos, con la fortaleza de nuestra Pachamama y gracias a Dios, refundamos Bolivia. Honor y gloria a los mártires de la gesta constituyente y liberadora, que han hecho posible esta nueva historia. (CPE Bolivia, 2009)

Geralmente, esses textos não passam por votação em separado, como uma cláusula, dessa forma se alcança um consenso prévio para a sua presença. Ao mesmo tempo que não possui caráter vinculativo, carrega um forte poder semiótico de introduzir e abrir direções para o texto, sentido que inspiram e são levados em conta pelos constituintes. Para o jurista Trindade (1988) o preâmbulo tem a característica fundamental de estabelecer e evocar princípios e valores. Há um valor político no preâmbulo constitucional, que remete à defesa de Carl Schmitt que diz que o excerto é a síntese da decisão política fundamental de um povo, como um teto ideológico aludindo a um sentimento constitucional ou a um fator de integração nacional.

\subsubsection{Referendo Dirimidor}

Em outubro de 2008 o Pacto Congressal aprova a lei para a convocatória do referendo dirimidor da CPE. O referendo era um mecanismo necessário para a adoção da CPE, desde a lei de convocatória para a AC. No entanto, quase um ano se passou de questionamento do processo da $\mathrm{AC}$ até que em 2008 o governo chega um acordo com a 
oposição. Concomitante aos longos meses de negociação ocorrem eventos de violências regionais em Pando e em Santa Cruz. Em meados de 2008 o presidente, por exemplo, esteve proibido - o termo melhor seria "ameaçado", de pousar ou entrar em Santa Cruz. A negociação que se deu dentro do congresso contou com a mediação de organizações internacionais e governos vizinhos e também com a vontade política de solucionar a crise social que começava a ganhar maiores proporções. A oposição negocia algumas mudanças no texto e é confeccionada os moldes do referendo. A pergunta de aprovação da CPE também questionava o tamanho das terras a qu seriam consideradas latifúndio. A questão sobre o latifúndio entra no referendo porque assim havia sido instituído: as questões sem consenso no CPE iriam também a referendo.

A CIDOB que até então havia colaborado de forma muito próxima com governo para que fosse garantida uma nova constituição fizeram vigília para a aprovação do Pacto Congressal e celebraram a Lei que aprovava o referendo. O Pacto Congressal é também celebrado pelo governo - como mais um passo rumo a refundação do país. Linera ao discursar em rede nacional enfatiza uma constituinte e um texto constitucional tal qual foi aprovado só foi possível pela história de mobilização e do esforço do povo que reivindicou frente ao Estado, construída a partir de baixo com representações outras que não só as políticas já tradicionais. Identificando o processo com o ímpeto popular, de base, traz o mecanismo de referendo como a possibilidade de ressignificar todos o processo, limpando-o de todas as imbróglios políticos, obstáculos de um discurso jurídico, e de fórmulas partidárias antigas que ainda influenciavam os caminhos desse processo.

Entre recusas da oposição, pairava na opinião pública diversas dúvidas e até movimentos sociais tinham posições críticas. Acusações de que a CPE era um texto fraco, e com lacunas que remetiam à insegurança jurídica, por exemplo, a referência a gratuidade da segurança social havia deixado de existir, ou que era totalitária na delimitação das ação do Estado e sua reconfiguração política e social. Se pronunciaram contra o projeto constitucional diversas agremiações de esquerda, como Defensores do Gás, camponeses de Aroma, a Universidade Pública de El Alto e setores do Movimento sem Terra concordaram que o projeto não afetava os interesses de grandes proprietários de terra. Esses e outras organizações sociais em reclame conjunto apontaram as seguintes falhas: a) saída da gratuidade da segurança social no artigo 45 , b) sujeição dos recursos hídricos a licenças e concessões - quando se defendia o mecanismo de cooperativas comunitárias para tanto, artigo 373 , c) proteção da propriedade privada que 
se encontram no interior de terras comunitárias de origem TCOs e a falta de retroatividade com relação as determinações latifundiárias, artigos 394 e 399, d) a constitucionalização dos contratos petroleiros com empresas transnacionais, artigo 262, e) a faculdade legislativa e executiva que ganhariam as autonomias departamentais segundo artigo 277, e a indígena que estaria sujeita a Constituição e a lei apenas, artigo 296. No entanto, apesar das críticas todos os movimentos de esquerda, próximo ao referendo em janeiro de 2009 mudam suas posições e se tornam favoráveis a CPE e as demais mudanças presentes em seu texto.

\subsubsection{Constituição aprovada}

O presidente boliviano Evo Morales saudou a vitória no referendo: o Estado Plurinacional da Bolívia - passava a se chamar assim, tinha uma nova Constituição. "Hoje é a refundação da Bolívia", comemorou, o discurso de Evo girava em torno do fim do Estado colonial, do colonialismo interno e externo. Outra matéria aprovada pelo referendo: tamanho máximo das propriedades rurais será de 5 mil hectares ${ }^{69}$. Duas semanas depois do referendo o presidente celebra em cerimônia oficial não em La Paz, mas em El Alto. Estavam presentes na cerimônia diversas autoridades de comunidades e lideranças de diversas organizações, houve também com uma espécie de desfile cívico que representava a "posesión de todas as autoridades" do novo Estado Plurinacional - a constituição restituiria o poder novamente ao povo que por sua vez havia iniciado o processo constitucional e o "processo de cambio". El Alto tinha ruas repletas de pessoas, estavam também presentes indígenas de todo o continente. Além de falar do simbolismo de um novo Estado e da plurinacionalidade, elementos de um discurso político tradicional para uma nação estão presentes, rebate a oposição conservadora e fala de eventos históricos que marcaram o sentimento de nacionalidade boliviana, e remete-se ao momento do Guerra do Chaco, como um momento que se pensa o país como um só. Linera em seu discurso pós referendo visualizava que a pós constituinte seria um momento mais estável e ainda importante em que as instituições deveriam se preparar para consolidar os avanços constitucionais, para o vice presidente esse processo de consolidação de todo o arcabouço institucional e de novas práticas levaria

${ }^{69}$ O "Sim" ganhou o referendo sobre a nova Constituição da Bolívia com cerca de $60 \%$ dos votos. Nos quatro departamentos onde a oposição ao presidente Evo Morales detém o poder o "Não" ganhou. Na pergunta sobre o tamanho máximo de uma propriedade agrícola (10.000 ou 5.000 hectares), a opção 5.000 ganhou por $78 \%$, tendo triunfado mesmo nos departamentos da chamda "meia lua" - reduto da oposição. 
ainda 10 anos para estar completo. Posição que difere do seu livro mais recente "Las tensiones creativas de la revolución" em que afirma que o Estado lida com contradições no processo de mudança e é o movimento social que o impulsiona para a sua própria superação, e que o tempo desse processo é aberto e não definido.

O novo texto amplia os direitos sociais e econômicos dos povos indígenas, num país em que $80 \%$ da população é formada por indígenas e mestiços que nunca se viram representados pelos governos de elite branca. Mais de 80 dos 411 artigos da nova Constituição abordam a questão indígena no país que já foi considerado o mais pobre da América Latina. Pelo texto, os 36 "povos originários" passam a dispor de uma quota obrigatória em todos os níveis de eleição, a ter propriedade exclusiva dos recursos florestais e direitos sobre a terra e os recursos hídricos. Num dos pontos mais polêmicos, é estabelecida a equivalência entre a justiça tradicional indígena e a justiça ordinária do país, autorizando tribos a julgarem e punirem suspeitos de crimes segundo os seus costumes tradicionais, e não de acordo com os preceitos jurídicos herdados da colonização espanhola. A nova Constituição prevê também uma representação indígena no Tribunal Constitucional e o direito à autodeterminação dos povos indígenas em terras comunitárias. "Esta bela terra nos pertence: aimarás, quéchuas, guaranis, chiquitanos... Os direitos dos que nasceram nesta terra são reconhecidos na nova Constituição", disse Morales durante a campanha do referendo... "Esse processo de mudança não tem volta, a Bolívia não retornará ao neoliberalismo", acrescentou o presidente boliviano no evento de celebração da refundação do Estado, transmitido pelos meios de comunicação para todo o país.

\subsubsection{Lutas para assegurar direitos conquistados na nova Constituição}

O momento pós referendo, com a nova constituição a ser aplicada é o pontapé das novas mudanças reais no interior do Estado e no seu conjunto de leis - momento o qual os movimentos acompanharão de perto. Durante os anos de 2009 e 2010 leis infraconstitucionais tiveram que ser formuladas pelo congresso, e novamente os maiores interessados pressionaram a casa, a oposição e principalmente governo, para terem suas demandas atendidas. A população da meia-lua amazônica esteve sob enfoque, principalmente porque os projetos de desenvolvimento fossem eles de infraestrutura ou de exploração de recursos estavam concentrados nessa área e tocariam nas particularidades das mais variadas organizações indígenas. Os momentos mais importantes para o movimento indígena foram a confecção da Lei de Regime 
Transitório Eleitoral, a Lei Marco de Autonomia e Descentralização e as discussões e demandas sobre consultas prévias - que deverão se tornar matéria de marco regulatório próprio, além de formar parte do conteúdo sobre o novo conjunto de Leis sobre recursos naturais também ainda por vir.

Seria difícil responder a todas as críticas, e a expectativa de haver mudanças importantes no formato do gabinete refletindo o novo desenho de Estado e a promessa de descolonizar e mudar a partir de dentro o Estado, a CIDOB enfatizou a falta de representatividade do oriente no gabinete, no entanto, ao menos conseguem um nome no ministério da Autonomia, o de Romero (MAS), que possui uma história de compromisso com as demandas indígenas da região. Por trás das demandas por maior representação do movimento social dentro dos gabinetes havia também uma sensação que pouca coisa havia mudado com a política partidária de composição e influência de um governo, ainda mais em um momento em que o MAS começa a perder aprovação popular, entrando em escândalos e pugnas internas.

Já o legislativo teve como uma de suas primeiras tarefas formular de maneira infraconstitucional uma lei eleitoral que desse cabo as mudanças previstas na CPE. O executivo defendia a criação de 14 circunscrições especiais, o PODEMOS defendia a criação de três, o MNR nenhuma e os originários e campesinos entre 18 (CIDOB) e 24 (CONAMAQ). No entanto vários analistas políticos sinalizavam que seria um desafio desenhar um órgão com esse nível de representatividade, e que isso poderia desequilibrar a dinâmica dessa casa e tornar o órgão menos eficiente ${ }^{70}$. A oposição faria de tudo para não perder mais espaço e adicionar todas essas novas representações incharia o desenho atual do legislativo. Na visão de Gisele Loprez (entrevista à analista política cruceña em 2009, no período pré referendo dirimidor), a criação de assentos especiais e minoritários seria uma luta difícil, apesar de fazer parte do compromisso feito no marco da plurinacionalidade, o governo tampouco se interessaria e se comprometeria com essas demandas não ligadas a massa de votos. As mudanças do Estado enfrentam novamente os desafios do Estado tradicional democracia partidária. Adolfo presidente do CIDOB chora no Congresso em discurso sobre a continuação de certa marginalidade histórica declarando como traidor não o Evo e não somente o MAS

70 Há um choque de definições por meio da CPE, ao passo que se poderia estar prevendo 36 novas circunscrições a determinação de que esse número seria fixo era um problema, e o texto também define que nos departamentos do país a metade dos deputados sejam uninomiais e o restante 50 porcento sejam plurinacionais, as circunscrições especiais rompem com esse princípio o mandato constitucional. $\mathrm{O}$ arranjo não poderia tirar o assento proporcional de outras representações. 
mas todo o sistema político que ainda deixam de fora a representação minoritária. A Confederação parece bastante frustrada. As organizações do oriente em conjunto se preparavam institucionalmente para essas demandas que planteavam, na formação de lideranças $^{71}$, que estariam prontas para ser mediador de suas comunidades nas instituições do Estado onde ocorre o processo decisório. Ao final fíca delimitado 7 circunscrições especiais para povos originários, a sub-representação foi considerada na prática como uma não representação de fato. Em determinado ponto Chiquitanos e Guaranis abrem mão dos seus assentos especiais para concorrer pela região, obedecem a lógica de que se eles fazem parte de uma circunscrição especial a participação deles será limitada, enquanto se recorrem a alianças políticas eles têm maiores possibilidades. Nesse momento, o CIDOB pede o reconhecimento de um padrão misto.

O processo interno para escolha dos representantes na Assembleia Plurinacional seria realizado escolhidos por aclamação ou voto popular. Os povos indígenas teriam então 27 representante nas Assembleias Legislativas dos governos departamentais divididos entre todos os departamentos do país, em Santa Cruz por exemplo foram cinco representantes na Assembleia Legislativa da região. Nas eleições para prefeitura algumas autoridades em departamentos tais quais o de Santa Cruz, de nove postulantes originários (em 56 municípios), cinco ganharam as eleições para a prefeitura, sob as siglas do MAS e da Organização Indígena Chiquitana (OICH). O MAS ganha ainda em outros municípios do oriente boliviano.

É no oriente do país que se começa a ter uma experiência muito singular de representantes fora da dinâmica partidária. Por ter um posicionamento independente que avança em suas conquistas quando as trocas políticas são feitas por meio de posicionamento partidário, fará com que a CIDOB declare que os indígenas se sentem como sanduíches dentro de uma dinâmica partidária: "quando se apoia o MAS se é 'massista', quando se apoia algum poder para região se é 'direitista'”, a declaração pede que se respeite a livre vontade dentro do sistema político mais aberto ao dissenso e a compromisso com suas instancias locais - de onde nasce a política e menos fechado em dualidades oposicionistas.

71 O projeto de formação de lideranças foi inclusive realizado a partir da colaboração da USAID, braço de cooperação internacional do governo estadounidense. Esse fato posteriormente servirá de acusações vindas do governo de Evo frente as pressões do CIDOB - classificando a confederação como cooptada por interesses estrangeiros. 


\subsubsection{A Lei Marco de Autonomia e Descentralização}

A Lei Marco de Autonomia e Descentralização (LMAD) é matéria do congresso em julho de 2010 e seu objetivo é regular a relação entre diferentes tipos de autonomias reconhecidas pela $\mathrm{CPE}$, respeitando uma coordenação entre o nível central do Estado e os governos autônomos. De forma geral a autonomia tem compromisso com o estabelecimento de espaço para a participação e controle social na gestão pública, a participação relativa ao desenho de políticas, de leis e planificações estratégicas e operativas, regulando as condições para a participação pluralista e para o controle de recursos e execução de obras (Governo da Bolívia, material informativo, 2010).

Ao abrir-se para a participação civil o Ministério de Autonomia começa a debater propostas. No entanto, o governo divide o movimento ao iniciar as conversações com a CIDOB e findar negociando propostas e subscrevendo um acordo somente com a APG. As negociações com a CIDOB são complicadas pois no corpo de propostas ainda está a reivindicação de maior representatividade na Assembleia Legislativa Plurinacional como demanda para uma autonomia plena. Volta então a luta para que se suba para 18 o número de assentos especiais, a CIDOB pressionará com marchas, suas demandas serão acusadas de anticonstitucionais. A razão pela qual a organização insistia na demanda era o caráter inconcluso e provisório ainda do marco regulatório da Lei do Regime Eleitoral e a possibilidade ainda de barganhar tais mudanças que de fato eram consideradas plataforma importante para os interesses indígenas da região.

Ao final o governo entra em acordo com a CIDOB e a marcha é interrompida em razão das condições climáticas e pelas baixas dos seus participantes. Para tanto Romero é retirado do seu cargo de ministro e representantes da CIDOB são ouvidos no Senado - a demanda por 18 assentos ainda não é acatada, essa e a consulta prévia vinculante é deixada para ser tratada posteriormente. As demandas que o governo inicialmente apontaou como inconstitucionais se referiam a) ao procedimento expedido para converter os territórios indígenas em autonomias indígenas, b) flexibilização dos requisitos para o reconhecimento das autonomias indígenas, c) o reconhecimento dos distritos municipais indígenas como entidades descentralizadas administrativamente e não como entidades desconcentradas, d) transferência de mais recursos para os territórios autônomos indígenas, e) aprovar seus estatutos por usos e costumes. O governo pretendia aprovar o Estado das Autonomias por referendo sendo que para muitos essa era uma prática distante e estranha a essas normas e procedimentos próprios que a CPE estaria reconhecendo. A mesma lógica estaria se repetindo no momento que 
o governo aprovava leis sem consultar os indígenas, quando tais decisões de alguma forma afetariam a sua população e território. Durante a GANPI em meados de 2010 há um clima de satisfação com relação as negociações no tema de autonomias, tinham conseguido uma mobilização em volta do tema e assim conseguiram aprovar $3 / 4$ da proposta original.

\subsubsection{Consultas livres, prévias e informadas}

Concomitante ao debate das autonomias se engrossa o debate sobre consultas. Em 2010 quando a VII Marcha pressiona pelo marco regulatório das autonomias indígenas, as organizações indígenas do oriente já sabem do projeto de infraestrutura do governo que poderia cruzar um território indígenas. O Cejis junto com outras organizações estão bastante presentes em perceber as falhas no processo informativo e consultivo junto as comunidades, durante 2009 e 2010 foram 17 os casos de reivindicação por consulta, fosse por atividades petroleiras, fosse por construção de estradas ou hidrelétricas o tema estava sem apoio institucional devido sob acusações de "chantagem indígena", e assim declinando de formular um processo de consulta.

$\mathrm{O}$ artigo 30 da CPE se refere ao direito que as populações tem de serem consultadas sobre qualquer projeto de exploração de recursos naturais que existam em seus territórios. A Lei 3058 de 2005 sobre Hidrocarburetos estabelece também a consulta obrigatória, compensações financeiras e indenização por danos e prejuízos, a Lei 1333 de 2009 também estabelece que deverá haver normas de avaliação de impactos ambientais e a proteção de áreas protegidas e sua compatibilidade com a existência de comunidades tradicionais. A esses mecanismos se soma o Convênio de 169 da OIT. Ainda assim o projeto das petroleiras PDVSA e YPFB no território de comunidades de Mosetén e Lecos foram, ao norte de La Paz causou polêmica, as empresas não aceitaram indenizar as comunidades. Segundo Chávez as empresas ofereceram churrascos para que a comunidade aceite em troca as obras, já Evo acusou os indígenas de má-fé ao tentarem extorquir as empresas interessadas em explorar os recursos naturais. Em Beni em novembro de 2010 a população Hoyen pede que sejam informados sobre os impactos da hidrelétrica. Afinal, mesmo que projetos não sejam realizados dentro do território, eles podem provocar impactos ambientais que afetem essas comunidades, uma liderança viajou até Cachuela para colher maiores informações e relatou que as informações conhecidas eram completamente vagas e declarou que as autoridades responsáveis deveriam cumprir com a missão de informar mais detalhadamente sobre o 
assunto. Também no oriente boliviano a estrada de $1390 \mathrm{~km}$ passaria pelo Paque Nacional Lión Lajas, território de povos Chiman Mostén e Tacana e afetaria diretamente seus bosques, com o deflorestamento necessário a obra da pista que afetaria também a vida dos animais, e favoreceria o aumento da extração ilegal de madeira.

$\mathrm{O}$ direito à consulta é uma ferramenta que defende sua livre-determinação, integridade étnica, cultural, territorial, participação e autonomia (Governo da Bolívia, material informativo, 2010). A Constituição estabelece que o direito de consulta é um mecanismo de democracia direta e participativa, pelo qual se abre diálogo entre povos indígenas e Estado e se incorpora a decisões administrativas e legislativas estatais a serem adotadas de forma livre e informada, com objetivo de gerar consensos e acordos. No entanto, o direito à consulta estaria sendo compreendido apenas como um aval simplificado, uma ferramenta técnica a ser regulamentada e sacramentada. Quando o diálogo mais profundo revelaria os impactos de tais intervenções e nesse contexto poderia se pensar conjuntamente o desenho de programas, projetos e/ou políticas em um concerto mais equilibrado das intervenções na sociedade e meio ambiente. $\mathrm{O}$ projeto nacional de desenvolvimento não deverá continuar sendo também monocultural, e não participativo, a ideia do viver bem entrará em choque com o objetivo de controle e acumulação de riquezas.

Organizações indígenas apresentaram frente ao Forum Internacional: “Aplicação do direito a consulta prévia, experiências, avanços e desafios para a construção da lei de hidrocarburetos e minério", essas configuravam um conjunto de propostas normativas a serem incorporadas a partir de um trabalho conjunto com representações locais, regionais, nacionais das organizações indígenas CIDOB, APG, CONAMAQ e representam uma posição propositiva e uma forte disposição em construir de maneira participativa leis sobre a matérias, no forum são convidadas e estão presentes figuras políticas tais quais Ministros de Hidrocarburetos. O que se vê é o alargamento do conceito de consulta, de impacto, de ideia de responsabilidade dos projetos no meio ambiente. Forçando um novo paradigma incipiente sobre desenvolvimento sustentável, cuidado ao meio ambiente, e principalmente debate social sobre essa temática.

Para o ano de 2011, e dentro da agenda de interesses de temas indígenas, está previsto o trabalho do congresso na Lei Marco de Consulta e Participação, a Lei de Hidrocarburetos e a Lei da Madre Tierra. Os indígenas possuem propostas também para um marco regulatório de Lei Florestal, proposta essa que no começo de 2011 foi entregue a Autoridade de Bosques e Terras (ABT). 
Em 2010 acontece a "VII Marcha Indígena del Oriente, Chaco y Amazonía Boliviana, por el Territorio, la Autonomía y los Derechos de los Pueblos Indígenas" a intenção é revitalizar os diálogos sobre a nova acomodação das nova estrutura do Estado. Governo e CIDOB entravam em desacordo e estavam de volta a mídia, no entanto, parecia indecifrável para a mídia e a opinião pública as motivações dessa querela. Duas partes que tinham tantas similitudes programáticas e tendo a CIDOB sido ainda aliada do governo nos momentos de conflito. No entanto, seria aconselhável a Bolívia se despedir de essencialismos para abraçar a as sobreposições de fato pluralistas, não haveria automatismos nessa relação entre CIDOB e governo e a reivindicação de voz seria agora passo constante. E o que a VII Marcha deseja é exatamente que suas propostas formuladas internamente respeitando a construção orgânica das demandas, sejam encaixadas e consideradas pelo Ministério das Autonomias na discussão no momento da formulação do Projeto de Lei Marco das Autonomias $^{72}$.

Para Nostas e Tejada (2010) a VII Marcha implica em um momento de nova posição e localização pós-constituinte, em que a CIDOB estabelece uma nova relação administrativa. A CIDOB reclama o compromisso acertado na CPE, relativo a algo que foi iniciado e precisa ser finalizado, o debate sobre as autonomias indígenas. Bienvenido Zacu membro da AC em seu discurso (2007) aponta os desafios da CPE:

"No entanto, entre a construção teórica do Estado Unitário Social de Direito Plurinacional Comunitário (CPE, artigo $1^{\circ}$ ) e a implementação do mesmo, transversalizando competências na estrutura institucional governamental e em todos os seus níveis, há uma distância que devemos ainda transitar responsavelmente, sem a ameaça da fragmentação social e territorial e sem as urgências que os constituintes impuseram em disposições transitórias, estabelecendo um prazo de 180 dias, a partir do início do novo mandato do governo, para a aprovação das cinco leis básicas.” (Gamboa, 2009)

Para tanto a CIDOB aos tempos e prazos institucionais e usa como estratégia dessa luta o mecanismo de elaboração de plataformas, levando as frente ao governo para iniciar um diálogo e posicionamentos. Essa posição propositiva vai além de uma oposição política, e estaria mais ligada a uma forma de vocação democrática paciente, sem deixar de lado seu pendor revolucionário (Nostas e Tejada, 2010).

As críticas mais contundentes ao governo no pós-constituinte foram levantadas

72 Considerando que as variadas comunidades do Oriente não teriam peso de representação no congresso, para que o projeto de lei fosse formulado fechado nessa casa, o debate sobre as autonomias deveria estar aberto ao diálogo com esses grupos. 
pelo movimento indígena no oriente. Os movimentos do altiplano se tornaram tão apáticos às demandas específicas do CIDOB que iniciou-se um clima de animosidade regional, em que se acusava a CIDOB de mudar de lado, ou de terem sido cooptados pelas elites regionais e, principalmente pela USAID e outras ONGs, e que haviam mudado seu discurso, quando no entanto ainda apoiavam o governo de Evo Morales, mas queriam poder cobrar e criticá-lo, de estar agora do lado dos tradicionalistas cruzeños. Dessa forma o diálogo entre as duas esferas foi bastante lento, por um lado a narração ia sendo contada pela mídia e por outro a CIDOB fazia questão de que o Ministro da Autonomia servisse de intermediário com o governo. A confederação teve bastante influência na escolha desse ministro, que em 2009 era cabeçado por um exassembleísta do MAS indicado pela própria CIDOB - Romero. 


\section{Conclusão}

A constituinte que se inicia em 2006 faz parte de um conjunto de processos sociais ligados tanto ao mundo andino quanto amazônico. No caso, há o contexto recente da IV Marcha dos Povos indígenas e a Guerra do Gás e da Água, subida de Evo Morales ao poder com maioria no congresso - que misturam reivindicações político e jurídicas com experiências políticas autônomas de gestão e também ganho de um local de poder importante. Podendo essas serem identificadas como lutas contrahegemônicas e pedidos de reconhecimento.

Em uma perspectiva de processos mais longos, está a sequência das lutas de resistência, relacionadas a um histórico de reivindicações das diferentes coletividades existentes na Bolívia. Essas passam tanto pela luta anticolonial de retomada de Tupac Katari e chegam até a luta por terras presente na Reforma Agrária. Por sua vez, tais lutas também apresentam diferentes estratégias, como o Movimento Katarista que se desdobra sindicalmente e partidariamente, ou ainda as experiências pouco estudadas de negociações dos indígenas com os jesuítas na Amazônia boliviana, entre tantas outras.

São colocadas aqui historicamente a fim de ressaltar as reivindicações diante de uma autoridade central, que será corporificada pelo Estado Nacional. Neste trabalho as diferentes organizações e movimentos são vistos em sua dinâmica institucional e de propostas, até chegar ao um complexo e atual cenário em que se acumulam todas essas experiências. $\mathrm{O}$ momento para a constituinte é um momento de grande aliança e busca de consenso frente a atores e estruturas conservadoras e que também irá aos poucos encontrando seus dissensos internos.

Dito isso o trabalho apresenta elementos que aproximam diferentes regiões e coletividade em um momento de busca por mudanças mais radicais e que por sua vez apenas é possível a partir da articulação desses vários grupos a nível nacional. Ironicamente, essa articulação tem como objetivo modificar a própria visão do que seria "nacional", "nação". Junto com isso mudanças estruturais no Estado para que ele dê conta da sua diversidade e alteridade. Descolonizar o Estado está atrelada a ideia de mudanças significativas em sua estrutura para dar conta de uma outra relação desses atores coletivos com o Estado, possibilitando sua entrada e sua força diante dele. Com políticas não apenas de caráter representativo, o Estado a ser descolonizado oferecerá a retomada das histórias dos povos originários, indígenas e campesinos. Para isso deve-se 
encerrar por um instante o olhar sobre o Estado e se voltar para as propostas dos movimentos e como seguem articulando. Além de perceber os contínuos desafios que surgem um "processo de mudança".

CIDOB, propostas para um Estado Plurinacional e autonomias indígenas

A CIDOB e as comunidades ligadas a ela teriam como estratégia a projeção política via suas autonomias indígenas. São porta vozes do valor plural na medida em que representam uma diversidade indígena minoritária dentro da população indígena boliviana e, ao levantarem as vozes para abertura de espaços para diálogo, o fazem com pequenas dissidências e particularidades. Essa pluralidade não seria antagonista, e por isso ainda é um desafio na cultura política de grande polarização em suas dissidências. A Nacionalidade deslocada para a Plurinacionalidade mudaria a percepção não só da força da maioria, mas também da minoria.

As autonomias como reivindicação cumpriram papel fundamental como um processo que projeta coletividade no Estado fazendo com que a cultura se realize e se expresse na interrelação dialética das pessoas com seu território. Guardando para que, talvez no futuro, esses mecanismos permitam a esses grupos se relacionarem em condições de igualdade e autodeterminação econômica, política e social, com outros espaços territoriais independentemente do tamanho da população.

Na proposta da CIDOB posteriormente a consensuada no Pacto de Unidad assim disserta sobre o status do novo Estado e o papel das autonomias nele:

Nuestra decisión de construir el Estado Plurinacional basado en las autonomías indígenas, originarias y campesinas debe ser entendida como un camino hacia nuestra autodeterminación como naciones y pueblos, para definir nuestras políticas comunitarias, sistemas sociales, económicos, políticos y jurídicos, y en este marco reafirmar nuestras estructuras de gobierno, elección de autoridades y administración de justicia, con respeto a formas de vida diferenciadas en el uso del espacio y el territorio. (ver anexo 3, pág. 176)

O reconhecimento dos seus territórios aparece como principal demanda histórica dos povos das terras baixas. Principalmente considerando que a Revolução de 1952 e a sua respectiva reforma agrária não tiveram impacto sobre essa região do país. Ao observar as negociações do movimento indígena do oriente com autoridades para regulamentação e pedido de direitos, e a consequentes marchas para pressionar e sensibilizar as autoridades é possível perceber que a questão das terras e território é seminal para entender a realidade dos povos amazônicos. Essa demanda une os 
diferentes povos da região e as questões que podem se desdobrar a partir daí aparecem em diferentes povos realidade, como a necessidade de gestão dos seus recursos naturais, ou outras definições relacionadas a sua auto-gestão e essa relacionada ao Estado.

A CIDOB enquanto movimento que se articula enquanto fala, elabora uma estratégia discursiva em seu processo de se estruturar e estruturar suas demandas. A fim de alcançar efetividade as encaixa ao processo decisório vigente e ao discurso do Estado - em sua parte que recebe demandas. $\mathrm{O}$ ajuste, efetividade e legimitação se dá por uma elaboração jurídica. Há, então, um aparato técnico jurídico não só dentro do diretório da CIDOB, mas também de organizações a elas vinculadas, como a CEJIS. Por sua vez esse discurso se ajusta também as lógicas de projeto de financiamento. Com uma equipe de advogados com forte sensibilidade política, o que é debatido internamente vira um pedido formal, elaborado que se encaixa com o processo decisório e o discurso do Estado. Assim a estratégia política da CIDOB passa por delinear a demanda, insere a no debate interno e externo e discursivamente coloca de igual para igual os interlocutores indígenas e as autoridades do Estado a ponto de na constituinte terem sido fortes colaboradores mesmo sem forte participação política em plenária.

Intelectualmente assim ela também se projeta, Carlos Romero, advogado de formação é natural de La Paz e se tornou presidente da CEJIS se veiculando fortemente a luta das terras baixas. Já fora da CEJIS escreve um livro sobre a quarta marcha que convoca uma Assembleia Constituinte. E ele irá se tornar o constituinte indicado pela CIDOB. Os intelectuais orgânicos andinos parecem ser mais numerosos e elaborar e relaborar posicionamentos políticos e ideológicos, no oriente, esse tipo de intelectual parece desviar da estrutura política vigente e parece querer ganhar marcos, que seriam muito difíceis não sendo uma maioria populacional, no entanto, ainda assim, a marca principal desse movimento são suas marchas, uma ação política direta, que pressiona ruma a um objetivo pontual. Essa ação também sinaliza uma ruptura com a possibilidade de diálogo, e em movimentos de caráter autonomista amplo, são em si uma intervenção política. Mesmo que pontuais e sinalizando rupturas, há um sentido de trajetória que se forma diante da independência política e do conjunto de demandas sob o horizonte das autonomias indígenas. Mesmo que essa característica se sobressaia na estratégia discursiva da CIDOB, ela apenas é possível e ganha força com um discurso político que o legitima enquanto discurso alternativo possível e forte, e nesse sentido, a CIDOB soube aproveitar o contexto político e a sua capacidade de fazer alianças.

Também com a demanda de uma nova Constituição os indígenas trazem como 
referência as reformas constitucionais ${ }^{73}$ em diferentes países da América Latina que nas últimas décadas buscaram se adaptar aos avanços no tema de minorias étnicas e mais especificamente no tema indígena. Várias delas influenciadas por avanços mais ou menos recentes na legislação internacional sobre o tema, como a Convenção 169 da OIT e também a até então recente Declaração Universal dos Povos Indígenas da ONU, de 2006, que traz à tona a questão da autodeterminação, autogoverno e autonomia. Para a sociedade civil o momento para mudanças profundas e para algumas experiências indígenas a oportunidade de um novo paradigma em que seus modos de viver coletivos - traduzidos agora como direitos coletivos, pudessem ser articulados na estrutura dessa sociedade plurinacional - o Estado-Plurinacional, em nível político, econômico, sóciocultural e jurídico, tangenciando a autonomia e encontro intercultural em instituições nacionais.

É fato que além de um redesenho do Estado deve existir uma legislação interna conectada a autonomia consquistada, por exemplo através de mecanismos internacionais. Pela Declaração 169 a consulta prévia é instituída como relacionamento político destes povos com os Estados nacionais. Seus principais elementos seriam 1) os eventos nos quais a consulta deve ser cumprida (medidas administrativas e legislativas que afetam diretamente os povos indígenas); 2) a oportunidade para sua realização (antes da adoção de qualquer decisão); 3) os interlocutores legístimo para a execução da consulta (As instituições representativas dos povos interrados); 4) a qualificação do processo consultivo (mediante procedimentos adequados a circunstâncias e de boa-fé); e 5) o objtivo final da consulta, que seria chegar a um consenso. No entanto, o Estado Plurinacional se divide entre se tornar um Estado provedor e desenvolvimentista e respeitas os projetos políticos e de desenvolvimento daqueles que almejam a autonomia (Covenção no 169, OIT. 1989)

Outra característica importante da estratégia da CIDOB enquanto confederação de povos é que os primeiros anos da organização foram investidos em articulação interna das comunidades e a formação das lideranças diante de lutas frente ao Estado que favoreceram a coesão e legitimação enquanto coletivo. A partir daí se alcança robustez e legitimidade enquanto voz e representação de uma região e dos seus povos

\footnotetext{
73 Ao passo que os países assinaram a Declaração 169, o arcabouço legislativo internacional foi provocado quase automaticamente a iniciar reformas constitucionais na América Latina que introduziram o trâmite legal básico para o reconhecimento do caráter multiétnico e pluricultural de suas respectivas nações. Muitas organizações e comunidades indígenas naturalmente utilizaram a declaração internacional e a posição dos Estados nos quais se inserem para impulsionar a sua luta.
} 
em torno de uma confederação. Mesmo que haja possibilidade de que centrais e níveis abaixo do CIDOB se representem autonomamente, como assim o faz a APG que incluso participou anteriormente de concertos com o CSUTCB e faz declarações e toma posições independentes.

\section{Autonomia nas Américas}

Meio a dificuldade de definir autonomia, seria mais fácil utiliza-la no plural, há diferentes experiências na América Latina e na própria Bolívia. Schavelson (2013:27) aponta que podemos entender a autonomia como lutas anticoloniais desses povos. A palavra de significado amplo aparece em circunstâncias diversas, nas Américas a Nicaragua a incorpora na Constituição em 1987. No México a discussão sobre a formação da autonomia tange seus formatos, por exemplo, que recortes ela teria, étnica, pluriétnicas, regional ou comunal? Com os zapatistas se desenvolveu independente do Estado, mas chegou-se a invocar lei de reforma constitucional a partir dos diálogos de San Andrés que ao cabo fracassaram. Ainda assim, em Oaxaca a autonomia esta vinculada ao aparato Estatal e incluso é reconhecida na constituição local, e nesse caso é importante notar que o estado de Oaxaca é conhecido pela sua maioria indígena. No Chile a busca por autonomia percorre uma história de perseguição às lideranças indígenas e já na Colômbia está bastante ligada a autodefesa e a tentativa de frear a violência que surge no campo. As formas de autonomia seriam tão diversas quanto são as estratégias do povos e organizações nos seus rituais de recuperação das suas tradições, ou na estratégia de reconstituição territorial ou até de chegada ao poder ou organização de força armada ou democrática.

$\mathrm{Na}$ Bolívia o debate atual, é iniciado com bastante força a partir do grupo Comuna, o qual vários intelectuais incluso o atul vice-presidente fez parte. Há uma proposta contra-Estado, relacionada a Raul Prada, uma proposta estatal de Linera, e ainda uma alternativa de Raquel Gutierrez que defende uma posição aberta distante da política estatal e próxima a auto-regulação (Schavelzon, 2013:37).

A necessidade do governo e do Estado de lidar com os variados interesses e a necessidade de lidar com as forças oferece um arranjo de forças que desafia a autonomia, algo que fica claro no processo da Constituinte. Segundo Schavelson:

Las contradicciones entre un modelo económico desarrollista y el cuidado del medio ambiente que resulta del modelo del "Vivir Bien" inspirado en los modos indígenas de vida e impulsado por el 
Gobierno del mas, que también se reflejarían en silencios o indefiniciones o ambigüedades del texto constitucional aprobado, entre la cuestión de la soberanía económica y la justicia social, de un lado, y de la búsqueda de autodeterminación y autonomía indígena, que de hecho es una de as oposiciones por las que transita el proceso boliviano, no se impusieron como obstáculos para el diálogo. En otras palabras, hubo choques, pero también una combinación que desde el encuentro del Pacto de la Unidad hasta las discusiones de los constituyentes y la nueva realidad de un Gobierno con nuevos actores dio lugar a un nuevo tiempo. Para entender esta combinación, una de las claves será la coexistencia de una política de lo minoritario con otra de las fuerzas mayoritarias de la nación, como dos componentes claves presentes en las distintas aristas del pensamiento político boliviano actual (2013:59).

Após a Constituinte, a CIDOB segue em marcha defendendo seus territórios e o avanço dos seus direitos sobre os seus territórios. A luta por autonomia indígena alcança o seu ápice na campanha a favor do TIPNIS, um tema fora da realidade campesina e urbana e que conquista a pauta política e a simpatia de luta popular. Neste momento a plurinacionalidade é veiculada a consolidação das autonomias indígenas e novamente a o projeto moderno do Estado é colocada em questão. Diante da centralidade que segue existindo o Estado enquanto fazer política, as organizações indígenas seguem independentes e iniciam uma particularização das suas demandas que as distancia do momento de construção de concensão e intensa articulação com variadas organizações sociais. Com um cenário de um Estado ainda bastante centralizador, o momento mais fragmentado dos movimentos surge como desafio para o avanço das lutas em prol da plurinacionalidade e autonomias indígenas.

O movimento indígena e o processo constituinte

De modo geral o processo constitucional foi tão desgastante e com repercussão tão pouco profunda que ao final seria difícil partir em defesa ou ataque de algum dos lados. Até porque para além das partes era o conteúdo importante e que estava sendo invisibilizado por posturas pouco colaborativas e conciliadoras. Em geral, quando as mídias se atinham em descrever os resultados das querelas, os mais moderados 
resumiam suas análises ao fato de que era um processo desgastado, que ao longo dos meses foi perdendo a credibilidade, uma posição semelhante com a velha descrença de como se fazia política na Bolívia. Essa posição estava baseada na narração dos embates, de polêmicas e das diferenças, dos lados, do espetáculo em que narrada a ação de um se espera a reação de outro, a mídia favoreceria a veiculação de uma luta entre dois lutadores em que um deles sairia vencedor. Nessa luta de regras naturalmente complexas e fluídas as duas partes usaram estratégias furtivas, boicotes, em um clima de pouca solidariedade. Tal processo não representava em si, a vontade de uma nova política, plural e solidária, e acreditar na solidez do seu texto meio a condições de seu processo parecia um desafio.

Na plenária da Assembleia Constituinte, local a nós remetido a partir do recorte temporal aqui dado, é também o local as oposições partidárias estão em conflito. A resistência das elites econômicas e setores conservadores em manterem seu status quo e não perderem seu poder decisório marca os trabalhos e os entraves da AC. Até mesmo se apropriam da estratégia de mobilização, greves e até violência nas ruas como forma de se contrapor as outras forças sociais emergentes. A força motriz da mudança segue em paralelo pautando e acompanhando os trabalhos da AC.

O caminho para um texto constitucional havia chegado ao seu fim, no entanto, a luta indígena e as marchas continuariam. A CIDOB estaria militando para o real compromisso e aplicação da CPE, e também para as definições que viriam com as leis infraconstitucionais fruto da CPE que assim garantissem a construção das autonomias indígenas e o respeito aos seus direitos.

O trabalho quis apresentar um ponto de vista fora do mundo Andino, como contraponto. No entanto, as organizações das terras baixas existem como tais e avançam como avançam também em grande medida por conta das lutas sociais e indígenas dos Andes. O desafio Andino de ocupar uma instituição moderna dentro de um sistema capitalista globalizado e se tornar plurinacional. Perceber e respeitar e dar espaço até mesmo às suas diferenças internas. É o conflito do Estado Nacional ou Plurinacional com ele mesmo.

A história da articulação dos povos indígenas colocada em perspectiva oferece os diferentes desejos de como querem viver os variados sujeitos coletivos existentes na Bolívia. São articulações e estratégias de sobrevivência em uma esfera política maior. Os heróis reinvocados e os movimentos indígenas seculares apontaram os objetivos a 
serem visados tais como, a retomada do poder, a retomada de um espaço/cidade/espaço comunal, também o desejo de se pensar pra além do Estado desde uma perspectiva cosmopolítica $^{74}$. Ou ainda a negociação e articulação com forças, de forma aparentemente contraditória com diversos atores presentes ao seu redor.

Ideias de plurinacionalidade foram apropriadas e reelaboradoras por todas as organizações sociais e, finalmente, pelo próprio Estado e governo de Evo Morales. Até o CSUTCB que por um lado teria como projeto a república aimará nas propostas à presidência em 2002, segundo Quispe, aparece como Plurinacional, na voz de Cárdenas, ou seja, articulando mais de uma identidade. $\mathrm{O}$ discurso inclusivo parece dar mais força e legitimidade, agrega e constrói pontes. No entanto, a plurinacionalidade e a ideia de que há projetos de nacionalidades em algum nível se trata no fundo de um discurso da alteridade e que surgirá eventualmente. Se falar de plurinacionalidade faz parte de uma "gramática de identidade/s" (Baumann \& Gingrich, 2004), as políticas decorrentes da autonomia indígena no Estado Plurinacional da Bolivía seriam por sua vez uma gramática de alteridades em construção. A primeira constituindo uma força centrípeta politicamente e a alteridade, centrífuga. Ellerbeck (2012) assim coloca:

"La Confederación Sindical Única de Trabajadores Campesinos de Bolivia (CSUTCB), con influencia fuerte del movimiento katarista, tuvo representación Guarani, Aymara y Quechua. Según Victor Hugo Cárdenas el katarismo no era un movimiento solo Aymara, era un movimiento para la plurinacionalidad (entrevista con Victor Hugo Cárdenas 28 de Abril 2012). Aunque Sarela Paz dijo que el elemento Guarani era más de una "cola" de la coalición principal de Aymaras y Quechuas (Entrevista con Sarela Paz 16 de Abril 2012), a lo menos, había los principios de un discurso inclusivo de diversas etnias desde los años 70-80.” (2012:3)

Há uma dificuldade inerente ao acompanhar a articulação entre movimentos, ao mesmo tempo que se aproximam e com isso tem mais força e articulam estratégias e alinham discursos, possuem claro suas diferenças e há naturalmente também uma dinâmica de autonomia política de cada um desses movimentos, principalmente em um momento de maior definição das políticas ligadas a essas demandas. Atualmente, todos os movimentos absorveram a demanda de plurinacionalidade como demandas próprias. Inclusive a apropriam enquanto princípio ou demanda histórica. Com isso não há necessidade de pretender afirmar a origem precisa desse processo ou desse conceito, ao contrário. A CIDOB não é a detentora da criação de um conceito de plurinacionalidade,

\footnotetext{
${ }^{74} \mathrm{http}: / /$ www.academia.edu/7802919/El_Pacto_de_Unidad_como_Encuentro_Cosmopol\%C3\%ADtico_R evista_de_Estudios_Bolivianos_-_2013_
} 
mas dentro dessa ideia de difícil definição certamente há uma busca de empoderamentos coletivos, que ora se articulam e são fortes e ora necessitam afirmar suas demandas específicas e não necessariamente vão ter apoio e consenso de diversos outros movimentos. O que vemos desde o primeiro capítulo são as formas como os movimentos crescem e são freados por outras forças e se fragmentam. Segundo Sarela Paz (2014) para compreender o cenário do conflito é essencial analisar as relações de força em jogo. E as forças não só entre o Estado e um movimento em particular, podendo aqui supor a contraposição que CONAMAQ e CIDOB fazem ao Governo de Evo Morales, mas também como os próprios movimentos internamente se fragmentam. Analisando pela perspectiva das relações de força há movimentos mais próximos ao governo que obtiveram grandes ganhos, como é o caso dos mineiros, com a "Ley de mineria" de 2014, no caso ganhos econômicos. Por sua vez os movimentos que conseguem pressionar articularam com outros movimentos e/ou aproveitaram o momento político. No caso da Confederação que reúne movimentos das terras baixas, dentre os vários motivos e estratégias que os fizeram pautar sua agenda está a própria visibilidade da região. Agora que a Amazônia sobe em sua importância econômica.

Assim como aconteceu na Guerra Civil de 1898, em que as forças que se contrapunham também refletiam mudanças no mapa das forças econômicas, quando Sucre deixa de pertencer a região mais rica do país, é possível projetar que o fato da região das Terras Baixas se caracterizar como uma região atualmente econômica forte, a faça com que aconteça uma contraposição natural à La Paz. Sarela Paz nos alerta a necessidade de observar as forças econômicas em ação, tanto próximos ao governo Evo ou aparentemente distantes dele (Paz, 2014).

Enquanto governo com projeto político que deseja se perpetuar no poder e negociar com uma diversidade de interesses, o governo de Evo frente às pressões mais fortes de organizações indígenas não tão alinhadas a sua base masista inicia um processo de querer influenciar essas organizações. Ocorre em 2012, uma divisão das lideranças, primeiro da CONAMAQ, sua presidência é questionada e refundada por um lado próximo ao MAS. Isso ocorre no momento de maior impasse entre as organizações indígenas e o conflito diante da consulta. Em 2013 o mesmo ocorre com a CIDOB, o que faz com que as duas organizações tenham duas lideranças e que a anterior se declare como "orgânica", junto a isso muitos supostos escândalos financeiros aparecem na mídia e enfraquecem as organizações frente a opinião pública. Essa dinâmica fortalece a centralidade do governo de Evo e é um retrocesso para articulação do "projeto político 
de plurinacionalidade" das organizações indígenas, no caso, da CONAMAQ e $\mathrm{CIDOB}^{75}$.

O desafio do Estado em se tornar Plurinacional

Wolf (2003) aponta que uma das análises do processo de formação das Nações possível para a antropologia é a de compreender os resultados do seu processo de integração. Analisa o modelo clássico, seminal europeu, e o faz a partir da perspectiva das forças hegemônicas, em que a estratificação e a simbiose de um Estado incipiente com uma classe burguesa comerciante delineia não só o Estado Nacional, mas também começa a delinear as relações de consumo e de dependência entre essas classes. A partir dessa análise é possível perceber a associação existente entre a formação do sistema capitalista e a formação do Estado. Assim como também explica Weber com detalhes sobre o aparelho do Estado, sua burocracia e todo o projeto moderno do Estado de controle, e da tecnicidade por trás da produção de riqueza. Para ajudar a compreender o processo de formação das Nações nas Américas assim como faz Wolf, a partir de uma perspectiva hegemônica, é preciso remeter-se as reflexões de Quijano (1956) e Mariategui (1979), que a partir de análises hegemônicas também inserem a questão do indígena, Quijano (1956) dando articulando o capitalismo colonial e o seu padrão de poder e o conceito de raça e Mariategui dando centralidade a questão indígena centralizada no problema das terras. Talvez ao considerar os dois no mesmo horizonte, o caso do Estado Plurinacional da Bolívia e do embate que se segue das organizações indígenas com o Estado durante e após a AC reatualiza-se suas contribuições, sobre Estado e colonialidade como um desafio ulterior e o desafio da heterogeneidade que acompanha a questão das terras e dos indígenas colocado por Mariategui.

Darcy Ribeiro (1970), ao analisar os povos indígenas americanos em seu conjunto, os historiciza e os descreve de acordo com seus diferentes processos de formação. A visão modernista presente no contexto político de superação do subdesenvolvimento também é encontrada na obra de Darcy e o faz priorizar a busca pela superação da desigualdade social entre esses diferentes povos (o povo testemunho - anterior a colonização, o povo novo - que nasce a partir do encontro desses povos e o povo transladado - que se deslocam até a América), a superação do subdesenvolvimento segue como questão em aberta na busca pela superação das desigualdades sociais.

${ }^{75}$ Entrevistas com Felix Titirico, Gonzalo Choque e Horacio Yugar 3 de maio 2012 apud Ellerbeck (2012). http://digitalcollections.sit.edu/cgi/viewcontent.cgi?article=2320\&context=isp_collection 
Adelia Ribeiro (2011) defende que Darcy não subestimava a autodeterminação dos povos e que sua obra pode ser lida como uma ênfase a evolução multilinear. O fato é que assumido os diferentes processos sociais em que estão incluídos os vários povos indígenas americanos, todos eles no contexto do Estado Nacional, como lidar com o possível choque mau entendidos entre a superação da desigualdade e a afirmação da diferença. Como superar a desigualdade em um contexto moderno e capitalista e respeitando outros modos de vida não necessariamente alinhados a esse modelo?

Darcy Ribeiro (1970) revela os diferentes povos presentes na América não apenas nativos, mas que se juntam no marco da colonização e o caráter da formação desses povos e conseguinte desigualdade - que por sua vez revela o conflito inerente a esse encontro. $\mathrm{O}$ interesse pelos processos de formação desses pov os posiciona tais povos a nível de nações (Ribeiro, 2011) e vai em encontro da história do próprio processo de formação do Estado Nacional. No caso Boliviano, o desafio é reconhecer todos esses processos no marco do Estado. É nec essário também perceber o que no processo de formação do Estado Nacional obliterou a história desses povos.

Darcy se preocupa em colocar que a superação de uma desigualdade é um projeto político que não deve considerar a realidade nacional de maneira uniforme. Dado o contexto de superação do subdesenvolvimento pelos países do sul, Darcy Ribeiro precede os debates multiculturalistas que irão discutir a superação da desigualdade considerando as relações assimétricas de diferentes grupos, ou como aponta Rita Segatto, a racialização que ocorre no próprio seio do Estado Nacional afim de apontar o outro, a fim de criar a diferença que cumprirá a estratificação necessária ao sistema. Para Rita é necessário uma política de identidade profunda e não apenas cosmética de identidades rotuladas, ao se tratar da política de identidade globalizada e o exemplo radical que a Bolívia oferece o título desse trabalho parte de um jogo de palavras onde as ações afirmativas, políticas de reconhecimento e inclusão patrocinadas pelo Estado se tornam Nações afirmativas, em referência a uma política de identidade radical em que a autodeterminação e a autonomia fazem parte de uma visão de país não apenas com diversidade, mas com alteridade em que há espaço para a emergência do conflito social, colocando em jogo estruturas e projetos políticos tradicionais do próprio Estado Nacional.

Desafios do Estado Plurinacional da Bolívia para os movimentos

O panorâma que se tem então é a da $\mathrm{AC}$ engessada e desgastada por conflitos, as mudanças conquistadas no texto da CPE poderiam perder força política se não 
pudessem ser ressocializadas e dentro da ação do Estado ainda tinham a necessidade de ser amplamente legitimada. O próprio referendo poderia ser a oportunidade não só de legitimação como de socialização das mudanças que estavam sendo propostas e admitidas. Após a frustração do bloqueio de pauta na discussão sobre autonomia indígena por conta dos setores conservadores terem colocado na pauta a autonomia regional e a base do governo ter lidado de forma cautelosa com as diferenças semânticas estruturais dessas duas autonomias e o que na discussão da autonomia indígena poderia ser capitalizado enquanto discurso pelo setor conservador. Ainda assim, a CIDOB assim como a CONAMAQ, permanecem próximos ao governo de Evo Morales e apoiam a aprovação da Constituição. No entanto, não celebram como se fosse um fim de uma luta, pois em menos de um ano estão novamente nas ruas cruzando o país em apoio a um marco regulatório das autonomias indígenas. Nessa ocasião já estavam cientes do projeto do governo de construir uma estrada que passaria por um território indígena, o TIPNIS, tema sobre o qual em 2011 iniciariam uma grande campanha em sua defesa.

A CIDOB tendo ciência dos limites da $\mathrm{AC}$ e da CPE, age de forma a utilizar as possibilidades abertas pela $\mathrm{CPE}$, alongando a sua luta para garantir as mudanças necessárias em um marco regulatório com forte presença da participação indígenas. Assim garantiriam os objetivos que os levaram às primeiras marchas. $O$ papel da CIDOB diante do marco do Estado Plurinacional vai além e está para além da Assembléia ou do Estado. Já que mesmo depois do marco regulatório, a consulta prévia abre uma polêmica que será desdobrada nacionalmente diante da necessidade de repensar o projeto econômico e de desenvolvimento centralizado do país.

Ironicamente, as organizações indígenas CONAMAQ e CIDOB no período da campanha em defesa do TIPNIS tiveram que responder a um desafio anterior as suas lutas, o desafio de poderem existir e manterem suas posições livres. O governo de Evo Morales usa sua base masista para estabelecer novos diretórios nas organizações e assim restabelecer uma base de apoio e resolver o conflito aberto com as organizações indígenas. Junto a isso as acusações de corrupção se tornam uma corrida difamatória pulverizada, enfraquecendo os movimentos indígenas como um todo, já que o escândalo era ligado ao Fundo Indígena. Desse modo atualmente a CIDOB e a CONAMAQ passam por um processo de enfraquecimento e fragmentação do movimento. As suas bases também se dividem ou observam o processo como relacionado ao grande jogo de políticas tradicionais. Como forma de se fortalecer, CONAMAQ e CIDOB se aliaram em uma frente que carrega o nome dos dois e fortalecem mutuamente seus diretórios 
orgânicos, em contraposição ao diretório governista e seus apoiadores. A resistência em que CONAMAQ e CIDOB seguem apontam para os desafios do próprio Estado em se tornar plurinacional e deixar de lado a centralidade do seu poder de decisão ou projetos que assumiu com determinados setores e que é englobado também pelo projeto moderno de Estado inserido no sistema de capitais.

Segundo Raul Prada (2012) as marchas enquanto prática política e rito se tornam uma linha de fuga que coloca em questão o Estado e as suas contradições enquanto Estado Plurinacional, pontuando seu projeto extrativista ao mesmo tempo que o Estado é ambientalista, modernizador e integrado ao mesmo tempo que é um Estado com autonomias. As marchas fariam então parte do próprio marco da plurinacionalidade, se pensarmos também o que Rita Segatto (2007) afirma sobre uma política de identidade que se abre para o conflito social e que colocará em cheque as forças hegemônicas, sem identidades compartimentalizadas, mas sim, abrirá uma mudança mais profunda em que classe, regiões de um mesmo país farão também parte do conflito. Alcides Badillo, diretor da Fundación Tierra ${ }^{76}$ ao sintetizar a comoção que o TIPNIS provocou no país afirma, não há Estado Plurinacional sem autonomias indígenas. O Estado Plurinacional passar por um marco em que o seu processo é restituído ao poder das demandas indígenas após as lutas que se seguem depois da Constituição e que visam preencher em práticas políticas as direções apontadas em um texto.

\footnotetext{
${ }^{76}$ Disponível em: http://www.erbol.com.bo/noticia/indigenas/31052014/sin autonomia indigena no hay estado plurin acional último acesso em março de 2015 .
} 


\section{Anexos}

\section{Anexo 1}

Anexo No 2. Población y grupo etnolingüístico

\begin{tabular}{|c|c|c|c|c|c|c|c|}
\hline $\begin{array}{l}\text { Araona } \\
\text { Población: } 92 \\
\text { Fam. } \\
\text { Lingũistica: } \\
\text { Takana } \\
\text { Ubicación: } \\
\text { Región } \\
\text { Amazónica } \\
\text { (Norte). } \\
\text { Departamento } \\
\text { de La Paz, } \\
\text { Provincia de } \\
\text { Iturralde. }\end{array}$ & \begin{tabular}{l|} 
Ayoreo \\
Población: 860 \\
Fam. \\
Lingüistica: \\
Aru o Jaqi. \\
Ubicación: \\
Región \\
Amazónica \\
(Norte). \\
Departamento \\
de Santa Cruz \\
Provincias de \\
Germán Busch \\
y Chiquitos.
\end{tabular} & \begin{tabular}{|l|} 
Baure \\
Población: \\
$496 \quad$ Fam. \\
Lingüistica: \\
Arawak. \\
Ubicación: \\
Región \\
Amazónica \\
(Norte). \\
Departamento \\
de Beni, \\
Provincia de \\
Itenez.
\end{tabular} & \begin{tabular}{|l|} 
Canichana \\
Población: \\
213 Fam. \\
Lingüistica: \\
Lengua \\
independie \\
nte. \\
Ubicación: \\
Región \\
Amazónica \\
(Norte). \\
Departame \\
nto de \\
Beni, \\
Provincia \\
de \\
Cercado.
\end{tabular} & \begin{tabular}{|l|} 
Cavineño \\
Población: \\
852 Fam. \\
Lingüistica: \\
Takana. \\
Ubicación: \\
Región \\
Amazónica \\
(Norte). \\
Departame \\
ntos de \\
Beni y \\
Pando, \\
Provincias \\
de Vaca \\
Diez y y \\
Ballivián, \\
Madre de \\
Dios y y \\
Manuripi. \\
\end{tabular} & $\begin{array}{l}\text { Cayubaba } \\
\text { Población: } \\
328 \\
\text { Fam. } \\
\text { Lingüistica: } \\
\text { Lengua } \\
\text { independiente } \\
\text { Ubicación: } \\
\text { Región } \\
\text { Amazónica } \\
\text { (Norte). } \\
\text { Departamento } \\
\text { de Beni, } \\
\text { Provincia de } \\
\text { Yacuma. }\end{array}$ & \begin{tabular}{|l|} 
Chácobo \\
Población: 255 \\
Fam. \\
Lingüistica: \\
Pano. \\
Ubicación: \\
Región \\
Amazónica \\
(Norte). \\
Departamento \\
derar Benl, \\
Provinolas de \\
Vacar Diez, \\
Yacuma, Gral. \\
Ballivián.
\end{tabular} & $\begin{array}{l}\text { Chimán } \\
\text { Población: } \\
4331 \\
\text { Fam. } \\
\text { Lingüistica: } \\
\text { Lengua } \\
\text { independiente } \\
\text { Ubicación: } \\
\text { Región } \\
\text { Amazónica } \\
\text { (Norte). } \\
\text { Departamento } \\
\text { de Benl, } \\
\text { Provincias de } \\
\text { Vaca Diez, } \\
\text { Yacuma, Gral. } \\
\text { Ballivián. }\end{array}$ \\
\hline $\begin{array}{l}\text { Chiquitano } \\
\text { Población: } \\
112 \text { 271 Fam. } \\
\text { Lingũistica: } \\
\text { Lengua } \\
\text { independiente. } \\
\text { Ubicación: } \\
\text { Región } \\
\text { Amazónica } \\
\text { (Centro- } \\
\text { Oriente). } \\
\text { Departamento } \\
\text { de Santa Cruz, } \\
\text { Provincias de } \\
\text { Ñuflo } \\
\text { Chávez, de } \\
\text { Velasco, } \\
\text { Chiquitos, } \\
\text { Germán Busch. }\end{array}$ & $\begin{array}{l}\text { Guaraní } \\
\text { Población: } \\
78438 \text { Fam. } \\
\text { Lingũistica: } \\
\text { Tupi-guarani } \\
\text { Ubicación: } \\
\text { Región del } \\
\text { Chacó } \\
\text { (Centro-Sur). } \\
\text { Departamento } \\
\text { s de Santa } \\
\text { Cruz, } \\
\text { Chuquisaca y } \\
\text { Tarija, } \\
\text { Provincias de } \\
\text { Cordillera, Luis } \\
\text { Calvo, } \\
\text { Hernando } \\
\text { Siles, } \\
\text { O'Connor, } \\
\text { Gran Chaco. }\end{array}$ & $\begin{array}{l}\text { Guarasugwe } \\
\text { Población: } 13^{1} \\
\text { Fam. } \\
\text { Lingüistica: } \\
\text { Sin } \\
\text { Información. } \\
\text { Ubicación: } \\
\text { Región } \\
\text { Amazónica } \\
\text { (Norte- } \\
\text { Centro). } \\
\text { Departamento } \\
\text { s de Santa } \\
\text { Cruz y Beni, } \\
\text { Provincias de } \\
\text { Ñuflo de de } \\
\text { Chavez y } \\
\text { Itenez. y }\end{array}$ & $\begin{array}{l}\text { Guarayo } \\
\text { Población: } \\
6 \text { 010 Fam. } \\
\text { Lingüistica: } \\
\text { Tupi- } \\
\text { guaraní } \\
\text { Ubicación: } \\
\text { Región } \\
\text { Amazónica } \\
\text { (Central). } \\
\text { Departame } \\
\text { nto de } \\
\text { Santa } \\
\text { Cruz, } \\
\text { Provincia } \\
\text { de } \\
\text { Guarayos. }\end{array}$ & $\begin{array}{l}\text { Itonama } \\
\text { Población: } \\
1 \text { 492 Fam. } \\
\text { Lingüistica: } \\
\text { Lengua } \\
\text { independle } \\
\text { nte. } \\
\text { Ubicación: } \\
\text { Región } \\
\text { Amazónica } \\
\text { (Norte). } \\
\text { Departame } \\
\text { nto de } \\
\text { Beni, } \\
\text { Provincias } \\
\text { de Itenez y } \\
\text { Mamoré. }\end{array}$ & $\begin{array}{l}\text { Joaquíniano } \\
\text { Población: } \\
169 \text { Fam. } \\
\text { Lingüistica: } \\
\text { Arawak } \\
\text { Ubicación: } \\
\text { Región } \\
\text { Amazónica } \\
\text { (Norte). } \\
\text { Departamento } \\
\text { de Beni, } \\
\text { Provincias de } \\
\text { Mamoré. }\end{array}$ & \begin{tabular}{|l} 
Leco \\
Población: \\
2443 \\
Fam. \\
Lingüistica: \\
Lengua \\
independiente. \\
Ubicación: \\
Región \\
Amazónica \\
(Occidente). \\
Departamento \\
de La Paz, \\
Provinclas de \\
Larecaja y \\
Franz Tamayo.
\end{tabular} & $\begin{array}{l}\text { Machíne ri } \\
\text { Población: } 15 \\
\text { Fam. } \\
\text { Lingüistica: } \\
\text { Arawak. } \\
\text { Ubicación: } \\
\text { Región } \\
\text { Amazónica } \\
\text { (Norte). } \\
\text { Departamento } \\
\text { de Pando, } \\
\text { Provincia de } \\
\text { Nicolás } \\
\text { Suárez. }\end{array}$ \\
\hline
\end{tabular}




\begin{tabular}{|c|c|c|c|c|c|c|c|}
\hline $\begin{array}{l}\text { Maropa } \\
\text { Población: } \\
2741 \text { Fam. } \\
\text { Lingũistica: } \\
\text { Takana. } \\
\text { Ubicación: } \\
\text { Región } \\
\text { Amazónica } \\
\text { (Norte). } \\
\text { Departamento } \\
\text { de Beni, } \\
\text { Provincia de } \\
\text { Balliviá. }\end{array}$ & $\begin{array}{l}\text { Mojeño } \\
\text { Población: } \\
43323 \text { Fam. } \\
\text { Lingũistica: } \\
\text { Arawak. } \\
\text { Ubicación: } \\
\text { Región } \\
\text { Amazónica } \\
\text { (Norte). } \\
\text { Departamento } \\
\text { de Beni, } \\
\text { Provincias de } \\
\text { Cercado, } \\
\text { Moxos, } \\
\text { Marbán, } \\
\text { Ballivián. }\end{array}$ & $\begin{array}{l}\text { Moré } \\
\text { Población: } 44 \\
\text { Fam. } \\
\text { Lingüistica: } \\
\text { Chapacura. } \\
\text { Ubicación: } \\
\text { Región } \\
\text { Amazónica } \\
\text { (Norte). } \\
\text { Departamento } \\
\text { de Beni, } \\
\text { Provinclá de } \\
\text { Mamoré. }\end{array}$ & $\begin{array}{l}\text { Mosetén } \\
\text { Población: } \\
813 \\
\text { Fam. } \\
\text { Lingüistica: } \\
\text { Lengua } \\
\text { independie } \\
\text { nte. } \\
\text { Ubicación: } \\
\text { Región } \\
\text { Amazónica } \\
\text { (Norte). } \\
\text { Departame } \\
\text { ntos de La } \\
\text { Paz y Beni, } \\
\text { Provincias } \\
\text { de Sud } \\
\text { Yungas, y } \\
\text { Ballivián. } \\
\end{array}$ & $\begin{array}{l}\text { Movima } \\
\text { Población: } \\
6183 \text { Fam. } \\
\text { Lingüistica: } \\
\text { Lengua } \\
\text { independie } \\
\text { nte. } \\
\text { Ubicación: } \\
\text { Región } \\
\text { Amazónica } \\
\text { (Norte). } \\
\text { Departame } \\
\text { nto de } \\
\text { Beni, } \\
\text { Provincia } \\
\text { de Yacuma. }\end{array}$ & $\begin{array}{l}\text { Pacahuara } \\
\text { Población: } 32 \\
\text { Fam. } \\
\text { Lingüistica: } \\
\text { Pano } \\
\text { Ubicación: } \\
\text { Región } \\
\text { Amazónica } \\
\text { (Norte). } \\
\text { Departamento } \\
\text { s de Beni y } \\
\text { Pando } \\
\text { Provincias de } \\
\text { Vaca Diez y } \\
\text { Manuripl }\end{array}$ & $\begin{array}{l}\text { Quechua } \\
\text { Población: } \\
1557689 \\
\text { Fam. } \\
\text { Lingüistica: } \\
\text { Quechua. } \\
\text { Ubicación: } \\
\text { Región Andinda } \\
\text { (Sur- } \\
\text { occidente). } \\
\text { Departamentos } \\
\text { de Chuquisaca, } \\
\text { Cochabamba, } \\
\text { Potosi, Oruro y } \\
\text { La Paz. (Varias } \\
\text { Provincias). }\end{array}$ & $\begin{array}{l}\text { Sirinióó } \\
\text { Población: } \\
134 \\
\text { Fam. } \\
\text { Lingüistica: } \\
\text { Tupi-guarani. } \\
\text { Ubicación: } \\
\text { Región } \\
\text { Amazónica } \\
\text { (Norte). } \\
\text { Departamento } \\
\text { de Beni, } \\
\text { Provincias de } \\
\text { Cercado y } \\
\text { Iténez. }\end{array}$ \\
\hline $\begin{array}{l}\text { Tacana } \\
\text { Población: } \\
3580 \text { Fam. } \\
\text { Lingũistica: } \\
\text { Takana } \\
\text { Ubicación: } \\
\text { Región } \\
\text { Amazónica } \\
\text { (Norte). } \\
\text { Departamentos } \\
\text { de La Paz y } \\
\text { Beni. Provincias } \\
\text { de Iturralde, } \\
\text { Ballivián y Vaca } \\
\text { Diez. }\end{array}$ & $\begin{array}{l}\text { Tapieté } \\
\text { Población: } 19 \\
\text { Fam. } \\
\text { Lingüistica: } \\
\text { Tupi-guarani. } \\
\text { Ubicación: } \\
\text { Región } \\
\text { Chaqueña } \\
\text { (Sur). } \\
\text { Departamento } \\
\text { de Tarija, } \\
\text { Provincia del } \\
\text { Gran Chaco. }\end{array}$ & $\begin{array}{l}\text { Uru } \\
\text { Población: } \\
1210 \\
\text { Fam. } \\
\text { Lingüistica: } \\
\text { Uru-chipaya. } \\
\text { Ubicación: } \\
\text { Región Andina } \\
\text { (Occidente). } \\
\text { Departamento } \\
\text { s de La Paz y } \\
\text { Oruro; } \\
\text { Provinclas de } \\
\text { Ingavi, } \\
\text { Atahuallpa, } \\
\text { Cercado, } \\
\text { Poopo, } \\
\text { Abaroa, } \\
\text { Sebastián } \\
\text { Pagador, } \\
\text { Ladislao } \\
\text { Cabrera, Sur } \\
\text { Carangas, y } \\
\text { Saucari. }\end{array}$ & $\begin{array}{l}\text { Weenha } \\
\text { yek } \\
\text { Población: } \\
1022 \\
\text { Fam. } \\
\text { Lingüistica: } \\
\text { Mataguaya. } \\
\text { Ubicación: } \\
\text { Región } \\
\text { Chaqueña } \\
\text { (Sur). } \\
\text { Departame } \\
\text { nto de } \\
\text { Tarija, } \\
\text { Provincias } \\
\text { de Gran } \\
\text { Chaco y } \\
\text { Yacuiba. }\end{array}$ & $\begin{array}{l}\text { Yaminahu } \\
\text { a } \\
\text { Población: } \\
45 \\
\text { Fam. } \\
\text { Lingüistica: } \\
\text { Pano. } \\
\text { Ubicación: } \\
\text { Región } \\
\text { Amazónica } \\
\text { (Norte). } \\
\text { Departame } \\
\text { nto de } \\
\text { Pando. } \\
\text { Provincia } \\
\text { de Nicolás } \\
\text { Suárez. }\end{array}$ & $\begin{array}{l}\text { Yuki } \\
\text { Población: } \\
112 \\
\text { Fam. } \\
\text { Lingüistica: } \\
\text { Tupi-guarani. } \\
\text { Ubicación: } \\
\text { Región } \\
\text { Amazónica } \\
\text { (Centro). } \\
\text { Departamento } \\
\text { de Cochabamba, } \\
\text { Provincia de } \\
\text { Carrrasco. }\end{array}$ & $\begin{array}{l}\text { Yurakaré } \\
\text { Población: } \\
1399 \\
\text { Fam. } \\
\text { Lingüistica: } \\
\text { Lengua } \\
\text { independiente. } \\
\text { Ubicación: } \\
\text { Región } \\
\text { Amazónica } \\
\text { (Norte-centro). } \\
\text { Departamentos } \\
\text { de Cochabamba } \\
\text { y Beni } \\
\text { Provincias de } \\
\text { Chapare, } \\
\text { Carrasco y } \\
\text { Moxos. y }\end{array}$ & \\
\hline
\end{tabular}

Fonte: CADPI, Nota técnica sobre cuestiones de los pueblos indígenas ESTADO

PLURINACIONAL DE BOLIVIA. FIDA, Novembro de 2012. 
Proposta de Nova Constituição pela CIDOB - versão reduzida

\section{PROPUESTA DE NUEVA CONSTITUCIÓN \\ DE LA CIDOB}

\section{TITULO PRELIMINAR \\ DISPOSICIONES GENERALES}

\section{[MODELO DEL NUEVO ESTADO]}

Artículo 1

Esta Constitución reconoce la preexistencia de las naciones y pueblos indígenas originarios, el dominio ancestral sobre sus territorios y garantiza su libre determinación que se expresa en la voluntad de conformar y ser parte del Estado Unitario Plurinacional, y en el derecho a controlar sus instituciones, al auto gobierno, a desarrollar su derecho y justicia propia, su cultura, formas de vida y reproducción, al derecho a reconstituir sus territorios y al derecho a definir su desarrollo con identidad.

Artículo 2

I. Bolivia es un Estado Unitario Plurinacional Comunitario, libre, independiente, soberano, democrático y social, que reconoce el pluralismo jurídico, político, cultural y lingüístico; descentralizado y con autonomías territoriales.

II. Garantiza la igual dignidad de las personas, las naciones, pueblos y culturas y, fomenta el respeto mutuo y el diálogo intercultural.

III. Se funda en los principios de unidad, solidaridad, reciprocidad, complementariedad, equidad social en la participación, distribución y redistribución de los productos y bienes sociales, con equidad de género, para "vivir bien".

\section{Artículo 3}

La población boliviana se compone de naciones y pueblos indígenas originarios campesinos y sociedad intercultural.

$[\ldots]$

\section{Artículo 5}

I. La soberanía reside en el conjunto de las naciones y pueblos indígenas originarios campesinos y población intercultural, es inalienable e imprescriptible y de la cual emanan las funciones y atribuciones del poder público. Se ejerce de forma directa y por medio de sus representantes en los términos que esta Constitución establece. Las funciones de los poderes ejecutivo, legislativo y judicial no podrán concentrarse en un solo órgano. 
II. El poder constituyente reside en las naciones y pueblos indígenas originarios campesinos y población intercultural; es inalienable imprescriptible y es indelegable a ningún otro poder público y, se lo ejerce en forma directa en defensa de la unidad de los intereses del Estado Unitario Plurinacional.

Artículo 6

I. El Estado Unitario Plurinacional adopta para su Gobierno la forma democrática, participativa, representativa y comunitaria.

II. La organización política se basa en el principio de participación de las naciones y pueblos indígenas originarios campesinos y población boliviana intercultural en la toma de decisiones, a través de sus mecanismos propios y, de los establecidos en esta Constitución; la responsabilidad individual y social del mandato; la revocabilidad y alternabilidad de cargos en todos los niveles del Estado.

III. La soberanía se ejerce mediante los siguientes mecanismos de democracia:

a. De democracia participativa, mediante Asambleas y Cabildos Comunitarios, Consulta previa, Referédum, Plebiscito, Iniciativa Legislativa Ciudadana y revocatoria de mandato.

b. De democracia representativa, mediante la elección de representantes por voto universal y secreto.

c. De democracia comunitaria, mediante la elección, designación o nominación de representantes por normas propias.

$[\ldots]$

Artículo 9

Los símbolos del Estado Unitario Plurinacional son: la bandera roja, amarilla y verde, la whipala, el himno nacional, el escudo de armas, la escarapela, la flor de la kantuta y la flor de patujú.

PARTE PRIMERA

DE LA PERSONA Y LA SOCIEDAD PLURAL COMO MIEMBROS DEL ESTADO

TITULO PRIMERO

DERECHOS Y DEBERES DE LA PERSONA

CAPITULO PRMERO

PRINCIPIOS DEL ESTADO UNITARIO PLURINACIONAL

Artículo 12

Los principios fundamentales están definidos por el respeto a la vida, la dignidad, la 
identidad y la soberanía. Los derechos son parte del bien común. Su reconocimiento constitucional en el Estado Unitario Plurinacional implica que todo derecho es lo que une a la colectividad y al mismo tiempo, expresa la legitimidad del derecho al respeto a la diferencia entre pueblos y entre personas.

Artículo 13

El Estado reconoce, protege, promueve y garantiza los derechos humanos individuales y colectivos, de las naciones y pueblos indígenas originarios y campesinos y de la población boliviana intercultural.

Artículo 14

La interpretación de los derechos en ningún caso puede, a través de una ley o decisión de autoridad administrativa o judicial, restringir el alcance de un derecho establecido en esta Constitución Política del Estado.

Artículo 15

Las declaraciones, derechos y garantías que proclama esta Constitución no serán entendidos como negación de otros derechos y garantías no enunciados que nacen de la soberanía del pueblo.

Artículo 16

Los instrumentos internacionales en materia de derechos humanos ratificados por el Estado Plurinacional Comunitario tendrán jerarquía constitucional.

Artículo 17

Los derechos establecidos en esta Constitución, tendrán carácter imperativo y no requieren la existencia de una ley reglamentaria para su cumplimiento.

Artículo 18

Las comunidades afrobolivianas tienen los mismos derechos que las naciones y pueblos indígenas originarios y campesinos del Unitario Estado Plurinacional.

\section{CAPITULO SEGUNDO DERECHOS INDIVIDUALES}

$[\ldots]$

Artículo 22

Se prohíbe toda forma de servidumbre o esclavitud: el patronazgo, el pongueaje, el sistema de habilito, la trata y el tráfico de personas o cualquier tipo de sometimiento forzado. Nadie podrá ser obligado a prestar trabajos personales sin su pleno consentimiento y justa retribución. 
Artículo 24

Se reconoce y garantiza el derecho de propiedad individual y colectiva, su ejercicio deberá asegurar en todos los casos el cumplimiento de una función social o económica social, según corresponda, su compatibilidad con el respeto a un desarrollo sustentable, equitativo y en armonía con el medio ambiente.

Artículo 25

Toda persona tiene derecho a la disidencia y protesta social contra las autoridades que actúen en contra del ordenamiento constitucional establecido.

\author{
CAPITULO TERCERO
}

DERECHOS POLÍTICOS

\title{
CAPITULO CUARTO
}

\section{DERECHOS DE CIUDADANIA Y NACIONALIDAD}

$[\ldots]$

Artículo 34

Los bolivianos de origen indígena, además tendrán derecho a su propia nacionalidad, en los términos fijados por Ley.

\author{
CAPITULO QUINTO \\ DERECHOS FUNDAMENTALES
}

[...]

\section{CAPITULO SEXTO \\ DEBERES DE LOS BOLIVIANOS}

Artículo 40

Son deberes de todos los ciudadanos bolivianos:

1. Acatar y cumplir la Constitución y las Leyes.

2. Preservar la unidad del Estado Plurinacional comunitario y su soberanía.

3. Promover la solidaridad en casos de desastres naturales y de acuerdo a sus necesidades. 
4. Practicar la solidaridad para las personas en situaciones de desamparo y con necesidad de rehabilitación.

5. Educar y cuidar a los hijos, proteger y socorrer a los padres cuando se hallen en situación de miseria, discapacidad, desamparo y vejez.

6. Preservar el medio ambiente, fauna y flora, y velar por los recursos naturales renovables y no renovables.

$[\ldots]$

\section{TITULO SEGUNDO \\ DERECHOS DE INTERÉS Y APLICACIÓN COLECTIVA}

Artículo 41

Se reconocen los derechos colectivos de los pueblos indígenas originarios y campesinos y de la población intercultural, que se definen y constituyen en sujetos del Estado Unitario Plurinacional para beneficiarse de las ventajas que ofrece esta Constitución en los términos de alcanzar una mejor posición y calidad de vida de la que actualmente gozan, de forma equitativa y solidaria.

\section{Artículo 42}

El Estado Unitario Plurinacional reconoce como derechos colectivos de las naciones y pueblos indígenas originarios y campesinos, los siguientes:

1. A la libre determinación

2. A la reconstrucción de sus territorios

3. A la consulta previa y vinculante

4. A la autonomía y al autogobierno

5. A la utilización sostenible, administración y conservación de los recurso naturales y sus componentes

6. A la explotación y aprovechamiento de los recursos naturales

7. Al control sobre los recursos naturales

8. A la Libre Expresión

9. A la libre circulación de Ideas mediante la palabra y la imagen

10. A expresar, crear y difundir obras en la lengua materna o tradicional

11. A integrarse con otros pueblos indígenas $u$ originarios

12. A la justa consideración de la autoría

13. A la prestación de bienes y servicios culturales

14. A la propiedad intelectual colectiva

15. A la Consulta Pública en el marco de las normas internacionales

16. A la información pública y privada

17. A participar en la formulación, aplicación y evaluación de los planes de desarrollo

18. A participar, con pleno consentimiento, en la elección y en el planteamiento de la modalidad para la consulta

19. A la representación en los niveles del Estado Unitario Plurinacional

20. A negociar su estatus político y cultural frente al Estado Unitario Plurinacional

21. A la propiedad colectiva de la tierra 
22. A la posesión sobre la tierra y el territorio

23. Al desarrollo sustentable

24. A la asistencia técnica y financiera de proyectos económicos

25. A la indemnización por desplazamiento forzado

26. Al saneamiento y la titulación de tierras

27. A beneficiarse del medio ambientales y sus recursos

28. A la evaluación ambiental para fines de control y desarrollo

29. A la información especializada en materia ambiental

30. A la participación dentro de las políticas estatales en torno a programas ambientales

31. A la indemnización por los perjuicios socio-ambientales

32. A los beneficios de la actividad forestal, agrícola y agropecuaria

33. A la formación laboral

34. A participar en las tareas educativas o sanitarias

35. A la libre asociación en el marco de la organización social

36. Al acceso y beneficios de la seguridad social

37. A la salud integral y programas de salud

38. Al reconocimiento y protección de prácticas médicas y religiosas tradicionales

39. A la educación y formación de calidad

40. A la educación bilingüe e intercultural

41. A la revisión y adecuación cultural de los programas oficiales de educación

42. A la educación en todos los niveles

43. A la educación respetuosa de las tradiciones

44. A participar en la elaboración, ejecución y gestión de programas de capacitación

45. A la Identidad indígena originaria y campesina

46. A la vida cultural que se elija

47. A la supervivencia cultural

48. A la integridad cultural

49. A la alternidad y al género en procesos democráticos

50. A la igualdad democrática

51. Al ejercicio del pluralismo jurídico en todas su expresiones y formas

52. A mantener y desarrollar las características propias de las identidades

53. Al reconocimiento de la ciudadanía en todos los niveles del Estado Unitario Plurinacional

54. Al la personalidad jurídica y el reconocimiento de las organizaciones y pueblos como sujetos de derecho público

55. Al uso e integridad de símbolos

56. A promover prácticas económicas

57. A la manutención y desarrollo de los sistemas legales e instituciones indígenas originarias y campesinas

58. A acceder a medidas de compensación históricas

59. A iniciar acciones legales ante la amenaza o concreción de la vulneración

60. A comprender y ser comprendido en los procesos legales

61. A la jurisdicción especial indígena

62. A determinar la estructura política y la composición de instituciones propias

63. A determinar las responsabilidades de los individuos para con sus comunidades y pueblos

64. A la restitución e indemnización por perjuicios causados

65. A la protección de la familia

66. A la maternidad y su asistencia

67. A la protección de la integridad de la mujer 
68. A la protección integral

68. A la alimentación y vestimenta de los menores

69. A la educación gratuita

70. A la salud o de asistencia médica

71. A vivir en libertad con seguridad

\section{TITULO TERCERO \\ DERECHOS DE LAS NACIONES Y PUEBLOS INDIGENAS ORIGINARIOS Y CAMPESINOS}

\section{Artículo 43}

El Estado Plurinacional Comunitario reconoce, garantiza y protege los derechos de las naciones y pueblos indígenas, originarios y campesinos, de acuerdo con sus sistemas normativos principios, saberes y valores.

Artículo 44

Las naciones y pueblos indígenas, originarios y campesinos tienen los siguientes derechos:

1. A la identidad cultural, la libre determinación y la territorialidad, en el marco de la unidad del Estado Plurinacional.

2. A la titulación colectiva de sus territorios

3. Al ejercicio de sus sistemas políticos, autoridades, autogobierno y administración de justicia y gestión autónoma de sus territorios.

4. Al desarrollo y sistemas económicos acorde a su cosmovisión y realidad, en la búsqueda del "vivir bien".

5. A ser consultados, mediante procedimientos apropiados y en particular a través de sus instituciones representativas, cada vez que se prevean medidas legislativas o administrativas susceptibles de afectarles. En este marco se reconoce y garantiza el derecho al consentimiento previo vinculante respecto a los recursos naturales que se encuentren en su territorio.

6. A que sus prácticas y visiones culturales sean valoradas, respetadas y promocionadas, como parte de la identidad del Estado Plurinacional, así como sus emblemas y vestimentas.

7. A una educación de acuerdo a su cultura, historia, lenguas, sus necesidades y aspiraciones, orientada a su fortalecimiento y a la construcción de una sociedad intercultural.

Artículo 45

Se respetan y garantizan las prácticas, los derechos intelectuales colectivos, los saberes en diversas ciencias y conocimientos ancestrales, tecnologías e innovaciones de las naciones y pueblos indígenas originarios y campesinos, así como su valoración uso y desarrollo.

Se prohíbe el registro de patentes y privatización sobre estos recursos, conocimientos ancestrales, biodiversidad y recursos genéticos. 
Artículo 46

Las naciones y pueblos indígenas, originarios y campesinos en peligro de extinción, aislamiento voluntario o no contactados gozan de protección del Estado. Los pueblos indígenas en aislamiento gozan del derecho a mantenerse en esa condición si así lo deciden.

Artículo 47

Se reconoce y garantiza el derecho a la participación directa de las naciones y pueblos indígenas, originarios y campesinos en toda la estructura del Estado Plurinacional. La elección y designación de sus representantes se hará a través de sus propias autoridades, instituciones, mecanismos y procedimientos en el marco de esta constitución.

TITULO CUARTO

ACCIONES DE GARANTIA Y RESGUARDO CONSTITUCIONAL

[temas genéricos de amparo legal]

$[\ldots]$

PARTE SEGUNDA

DEL ESTADO UNITARIO PLURINACIONAL

TÍTULO PRIMERO

ESTRUCTURA DEL ESTADO UNITARIO PLURINACIONAL

\author{
CAPÍTULO I \\ DISPOSICIONES GENERALES
}

Artículo 56

I. El Estado Unitario Plurinacional Comunitario, organiza y estructura su gobierno conformado por el Poder Legislativo, Ejecutivo y Judicial y se basa en la independencia, división y coordinación de estos Poderes.

II. Reconoce al interior del Estado Unitario Plurinacional a los gobiernos descentralizados y autónomos Indígenas Originarios Campesinos, Departamentales y Municipales

Artículo 57

El Estado Unitario Plurinacional Comunitario incorpora la participación de las naciones $\mathrm{y}$ pueblos indígenas originarios campesino y población intercultural, en todos sus poderes, órganos e instancias de gobierno, según las formas que establece esta Constitución y las Leyes.

\author{
TITULO SEGUNDO \\ ORGANO LEGISLATIVO
}

CAPITULO PRIMERO 


\section{ASAMBLEA PLURINACIONAL}

\section{Artículo 58}

El Poder Legislativo se ejerce a través de la Asamblea plurinacional. Es Unicameral, esta compuesta por representantes de las naciones y pueblos indígenas originarios campesinos, y representantes de las circunscripciones territoriales uninominales y departamentales.

Artículo 59

I. El órgano Legislativo está conformado por 50 representantes de las naciones y pueblos indígenas, originarios y campesinos; elegidos, nominados o designados directamente por normas propias; 70 representantes de las circunscripciones territoriales uninominales y 3 representantes por cada departamento.

II. La representación de las naciones y pueblos indígenas originarias y campesinos en la Asamblea Plurinacional deberá integrarse con la representación de cada una de las naciones y pueblos indígenas originarios y campesinos sin exclusión alguna, de tal forma que la representación indígena originaria y campesina refleje la composición Plurinacional del Estado en base a criterios de identidad y pertenencia cultural y a criterios demográficos.

Artículo 60

La Asamblea inaugurará su periodo legislativo, en la ciudad de Sucre, Capital de la República cada 6 de agosto, aun cuando no hubiese convocatoria.

Artículo 61

El periodo ordinario de sesiones comprenderá noventa días útiles, prorrogables hasta ciento veinte, a juicio de la Asamblea o a petición del Poder Ejecutivo. Si a juicio de éste conviniese que la Asamblea no se reúna en la sede de sus funciones, podrá expedir la convocatoria señalando otro lugar.

Artículo 62

La Asamblea podrá reunirse extraordinariamente por acuerdo de la mayoría absoluta de sus miembros o por convocatoria del Poder Ejecutivo. En cualquiera de estos casos sólo se ocupará de los asuntos consignados en la convocatoria.

Artículo 63

Todo representante de la Asamblea tendrá la obligación de asistir a las convocatorias de sus representados, conforme a procedimiento establecido por Ley.

Artículo 64 
Los miembros de la Asamblea están prohibidos de ejercer otro cargo público o privado hasta cumplir su mandato.

Artículo 65

El representante podrá ser reelegido por única vez y su mandato es revocable, conforme al mecanismo de su elección.

Artículo 66

No podrán ser elegidos Representantes:

a. Los funcionarios públicos y empleados civiles, los militares y policías en servicio activo y los eclesiásticos de cualquier culto con jurisdicción, que no renuncien y cesen en sus funciones y empleos por lo menos sesenta días antes del verificativo de la elección. Se exceptúan de esta disposición los catedráticos de Universidad.

b. Los contratistas de obras y servicios públicos; los administradores, gerentes y directores, mandatarios y representantes de sociedades o establecimientos en que tiene participación económica el fisco y los de empresas subvencionadas por el Estado; los administradores y recaudadores de fondos públicos mientras no finiquiten sus contratos y cuentas.

Artículo 67

Los Representantes son inviolables por las opiniones que emitan en el ejercicio de sus funciones.

Artículo 68

El Vicepresidente del Estado Unitario Plurinacional es Presidente Nato de la Asamblea y tiene las prerrogativas establecidas para los Representantes.

Artículo 69

Los Representantes no podrán adquirir ni tomar en arrendamiento, a su nombre o en el de terceros, bienes públicos, ni hacerse cargo de contratos de obra o de aprovisionamiento con el Estado, ni obtener del mismo concesiones u otra clase de ventajas personales. Tampoco podrán, durante el período de su mandato, ser funcionarios públicos, empleados civiles, apoderados ni asesores o gestores de entidades autárquicas, ni de sociedades o de empresas que negocien con el Estado.

La contravención a estos preceptos importa pérdida del mandato popular.

Artículo 70

Durante el período constitucional de su mandato los Representantes podrán dirigir representaciones a los funcionarios del Poder Ejecutivo y de la administración pública para el cumplimiento de las disposiciones legales.

Artículo 71 
Las sesiones de la Asamblea serán públicas, y sólo podrán ser reservadas cuando dos tercios de sus miembros así lo determinen, en situaciones que pongan en riesgo la seguridad nacional.

Artículo 72

La comunicación al interior de la Asamblea será plurilingüe.

\section{CAPITULO SEGUNDO ATRIBUCIONES DE LA ASAMBLEA PLURINACIONAL}

\section{Artículo 73}

Las atribuciones de la Asamblea Plurinacional, son las siguientes:

1. Dictar leyes, abrogarlas, derogarlas y modificarlas.

2. Interpretar la Constitución y las Leyes

3. Crear impuestos y contribuciones de cualquier naturaleza, suprimir las existentes y determinar su carácter nacional, departamental, regional, local, universitario y judicial, así como aprobar los gastos fiscales. La Asamblea Plurinacional, a pedido de uno de sus miembros, podrá requerir del Ejecutivo la presentación de proyectos sobre impuestos y contribuciones. Las contribuciones se establecerán por tiempo indefinido, salvo que las leyes respectivas señalen un plazo determinado para su vigencia.

4. Considerar y aprobar los planes nacionales de desarrollo que el Poder Ejecutivo pase a su consideración.

5. Autorizar y aprobar la contratación de empréstitos que comprometan las rentas generales del Estado, así como los contratos relativos a la exploración, explotación, aprovechamiento, transporte, refinación e industrialización de los bienes y recursos naturales no renovables. Ningún contrato entrará en vigencia ni obliga al Estado sin la previa aprobación de la Asamblea.

6. Conceder subvenciones o garantías de interés para la realización e incremento de obras públicas y de necesidad social.

7. Autorizar la enajenación de bienes nacionales y universitarios.

8. Autorizar a las universidades la contratación de empréstitos.

9. Establecer el sistema monetario.

10. Aprobar anualmente la cuenta de gastos e inversiones que debe presentar el Poder Ejecutivo en la primera sesión de cada legislatura. 
11. Ratificar o denunciar los tratados, concordatos y convenios internacionales. Ningún tratado, concordato o convenio internacional podrá ratificarse si contraviene los preceptos constitucionales.

12. Aprobar, en cada legislatura, la fuerza militar que ha de mantenerse en tiempo de paz.

13. Autorizar la salida de tropas nacionales del territorio plurinacional, determinando el tiempo de su ausencia.

14. Aprobar la creación de Departamentos, Regiones, Municipios y Entidades Territoriales Indígenas Originarias, sus Estatutos y forma de organización, así como fijar sus límites.

15. Habilitar puertos mayores.

16. Conceder indulto, previo informe del Tribunal Supremo de Justicia.

17. Seleccionar y aprobar la lista de candidatos por mayoría absoluta de votos de sus miembros para: Miembros del Tribunal Supremo de Justicia, Miembros del Tribunal Constitucional, Fiscal General de la República, Procurador, Contralor, Miembros de Justicia Administrativa y Defensor del Pueblo.

18. Designar representantes ante las Juntas Electorales.

19. Ejercer, a través de las Comisiones de la Asamblea Plurinacional, la facultad de control y fiscalización sobre las entidades autónomas, autárquicas, semiautárquicas y sociedades de economía mixta.

20. Proponer ternas al presidente del Estado Unitario Plurinacional para la designación de presidentes de entidades económicas y sociales en que participe el Estado.

21. Rehabilitar como bolivianos, o como ciudadanos, a los que hubiesen perdido estas calidades.

22. Autorizar a los bolivianos el ejercicio de representación del Estado Unitario Plurinacional Comunitario y la admisión de títulos o emolumentos de gobierno extranjero.

23. Aprobar las ordenanzas y resoluciones de los gobiernos descentralizados y autonómicos, relativas a tasas y patentes.

24. Decretar honores públicos a quienes lo merezcan por servicios eminentes al Estado Unitario Plurinacional Comunitario.

25. Aceptar o negar, en votación secreta, los ascensos a General de Ejercito, de Fuerza Aérea, de División, de Brigada, Almirante, Vicealmirante, Contraalmirante de las Fuerzas Armadas, y General de Policía Nacional, propuestos por el Poder Ejecutivo. 
26. Aprobar o negar el nombramiento de Embajadores y Ministros Plenipotenciarios propuestos por el Presidente.

27. Calificar las credenciales otorgadas por las Juntas Electorales.

28. Organizar su Mesa Directiva y dictar su reglamento.

29. Separar temporal o definitivamente, con el acuerdo de dos tercios de votos, a cualesquiera de sus miembros por graves faltas cometidas en el ejercicio de sus funciones.

30. Fijar las dietas de los Asambleístas que en ningún caso será superior al salario percibido por el Presidente del Estado Plurinacional, están prohibidos de percibir cualquier otro ingreso adicional del fisco.

31. Ordenar el pago de sus presupuestos; nombrar y remover su personal administrativo y atender todo lo relativo a su economía y régimen interno.

32. Realizar las investigaciones que fueren necesarias a través de sus comisiones para el cumplimiento de sus atribuciones constitucionales.

33. Inaugurar y clausurar sus sesiones.

34. Verificar el escrutinio de las actas de elecciones de Presidente y Vicepresidente del Estado Unitario Plurinacional Comunitario.

35. Recibir el juramento de los dignatarios del Estado Unitario Plurinacional Comunitario, admitir o negar su renuncia.

36. Considerar las leyes vetadas por el Ejecutivo.

37. Considerar y resolver la declaratoria de guerra a petición del Ejecutivo.

38. Determinar el número de efectivos de las Fuerzas Armadas del Estado Unitario Plurinacional Comunitario.

39. Legislar con procesos de consulta en temas de interés de las naciones y pueblos indígenas, originarios y campesinos y de interés común.

40. Fiscalizar las políticas de Estado Unitario Plurinacional Comunitario sobre recursos naturales.

$[\ldots]$

Artículo 77

\section{PROCEDIMIENTO LEGISLATIVO}

a) Las leyes pueden tener origen a proposición de uno o más de los miembros de la Asamblea Plurinacional, del Vicepresidente del Estado Plurinacional o por mensaje 
del Poder Ejecutivo que será sostenido en los debates por el Servidor Secretario del respectivo despacho.

b) El Tribunal Supremo de Justicia podrá presentar Proyectos de Ley en materia de administración de justicia y reforma de los códigos mediante mensaje dirigido a la Asamblea Plurinacional.

c) Los ciudadanos y las organizaciones sociales mediante iniciativa legislativa podrán presentar directamente a la Asamblea Plurinacional proyectos de Ley sobre cualquier materia, siempre que cuenten con el respaldo de un porcentaje de firmas de electores a establecerse mediante ley.

d) Todo proyecto de ley que comprometa o pueda afectar los intereses de una nación o pueblo indígena originario y campesino deberá ser previamente consultado a las naciones y pueblos interesados.

$[\ldots]$

\author{
TITULO TERCERO \\ ORGANO EJECUTIVO \\ CAPITULO PRIMERO \\ EJECUTIVO PLURINACIONAL
}

Artículo 87

$[\ldots]$

III. El mandato del presidente y del vicepresidente es de 5 años y podrán ser reelectos por una sola vez para un nuevo periodo constitucional.

Artículo 88

Los Ministros de Estado serán designados por el Presidente, de los cuales, un 50\% serán mujeres y deberá integrarse reflejando la composición plurinacional del Estado.

Artículo 89

El mandato del Presidente y Vicepresidente es revocable, mediante consulta directa popular, la cual será convocada a solicitud certificada de al menos el $10 \%$ del padrón electoral y normada por ley.

\author{
CAPITULO SEGUNDO
}

PRESIDENTE Y VICEPRESIDENTE 


\section{CAPITULO TERCERO}

\section{SERVIDORES SECRETARIOS DE ESTADO}

$[\ldots]$

Artículo 103

\section{TÍTULO CUARTO \\ ÓRGANO JUDICIAL \\ CAPÍTULO I \\ DISPOSICIONES GENERALES}

I. La administración de justicia se basa en el pluralismo jurídico, entendido como la existencia de varios sistemas con sus respectivas jurisdicciones y competencias.

II. La potestad de administrar justicia se ejerce a través de la jurisdicción ordinaria, la jurisdicción administrativa $\mathrm{y}$ de la jurisdicción indígena originaria $\mathrm{y}$ campesina.

III. El Estado Unitario Plurinacional garantiza la imparcialidad a todos los ciudadanos en el acceso a la justicia. Su orientación primordial es la de asegurar la igualdad ante la ley, un debido proceso en el marco de la diversidad del Estado Plurinacional.

\section{CAPITUO II}

Artículo 104 (De la jurisdicción indígena originaria y campesina)

I. La jurisdicción indígena originaria y campesina se ejerce a través de sus autoridades de acuerdo a sus normas y los sistemas jurídicos propios de cada nación y pueblo indígena originario y campesino y se ejerce en con las competencias siguientes:

a) Competencia en cuanto al territorio.- Para administrar justicia en sus comunidades, pueblos y gobiernos indígenas autónomos.

b) Competencia en cuanto a la materia.- Para administrar justicia en cualquier asunto o materia

c) Competencia en cuanto a las personas.- Para administrar justicia y hacer respetar sus normas a cualquiera de sus miembros o personas ajenas que violaren o cometieran hechos contra sus miembros, sus territorios, recursos naturales, bienes e intereses.

II. La jurisdicción indígena originaria y campesina al momento de imponer sanciones, deberá observar el respeto al derecho a la vida, la integridad física y 
la dignidad de las personas y a los derechos humanos interpretados culturalmente en concordancia con las normas propias de cada pueblo.

III. Las decisiones de la jurisdicción indígena originaria y campesina tienen validez nacional y no son revisables por la jurisdicción ordinaria.

IV. En casos de conflicto de competencias con la jurisdicción ordinaria o administrativa o presunta violación de derechos humanos, el conflicto o presunta violación de derechos humanos será conocido por el Tribunal Constitucional o por una instancia jurisdiccional compuesta por autoridades de las jurisdicciones en conflicto.

V. Una ley regulara los mecanismos de coordinación y cooperación entre las jurisdicciones indígenas originarias y campesinas, la jurisdicción ordinaria y administrativa.

VI. El Tesoro General del Estado Unitario Plurinacional Comunitario asignará una partida anual para la infraestructura, equipamiento y fortalecimiento de la jurisdicción indígena originaria y campesina

\title{
CAPITULO III
}

Artículo 105 (De la jurisdicción ordinaria)

$[\ldots]$

\author{
CAPÍTULO IV \\ TRIBUNAL SUPREMO DE JUSTICIA
}

\section{CAPITULO V}

$[\ldots]$

e. Decidir, con anterioridad al pronunciamiento popular, sobre la constitucionalidad de la convocatoria a un referendo o a una Asamblea Constituyente para reformar la Constitución, sólo por vicios de procedimiento en su formación.

f. Decidir sobre la constitucionalidad de los referendos sobre leyes y de las consultas populares y plebiscitos del orden nacional. Estos últimos sólo por vicios de procedimiento en su convocatoria y realización.

Artículo 111

En los niveles subnacionales funcionarán los tribunales administrativos autónomos, cuya composición y atribuciones así como su organización, será establecido mediante Ley.

Artículo 112 
Los conflictos sobre el uso, acceso y aprovechamiento de los recursos naturales son de competencia de la judicatura administrativa, sin perjuicio a lo que establezca la presente Constitución respecto a los derechos de los pueblos indígenas, originarios campesinos y la población intercultural.

\author{
CAPÍTULO III \\ TRIBUNAL CONSTITUCIONAL \\ $[\ldots]$ \\ TÍTULO QUINTO \\ OTROS ÓRGANOS INSTITUCIONALES DEL ESTADO UNITARIO \\ PLURINACIONAL \\ CAPÍTULO I \\ CONTRALORIA GENERAL
}

$[\ldots]$

Artículo 116

$[\ldots]$

e). La Contraloría General del Estado Plurinacional tendrá el control fiscal sobre las operaciones de entidades autónomas, autárquicas y sociedades de economía mixta, gobiernos municipales, gobiernos departamentales, Comunidades Autónomas y Universidades Publicas.

CAPÍTULO SEGUNDO

PROCURADURÍA DEL ESTADO PLURINACIONAL

$[\ldots]$

\author{
CAPITULO TERCERO \\ MINISTERIO PÚBLICO
}

CAPITULO CUARTO

DEFENSOR DEL PUEBLO

\title{
$[\ldots]$
}

Artículo 133

El Defensor del Pueblo dará cuenta de sus actos a la Asamblea Plurinacional por lo 
menos una vez al año, en la forma que determine la Ley, y podrá ser convocado por cualesquiera de las comisiones de la Asamblea Plurinacional, en relación al ejercicio de sus funciones.

PARTE TERCERA

RÉGIMEN DE DESCENTRALIZACIÓN Y AUTONOMÍA

TÍTULO PRIMERO

ORDENAMIENTO TERRITORIAL

CAPÍTULO I

DISPOSICIONES GENERALES

RÉGIMEN DE DESCENTRALIZACIÓN Y AUTONOMÍA

TÍTULO PRIMERO

ORDENAMIENTO TERRITORIAL

CAPÍTULO I

DISPOSICIONES GENERALES

\section{REORDENAMIENTO TERRITORIAL, DESCENTRALIZACION Y AUTONOMIAS \\ DISPOSICIONES GENERALES}

\section{Artículo 135 (Reordenamiento territorial)}

I. El Estado Unitario Plurinacional Comunitario con la finalidad de adecuar el ordenamiento territorial a la realidad socioeconómica, cultural, geográfica, ecológica, a la organización y el carácter Plurinacional del Estado Unitario Plurinacional Comunitario y la integración de las distintas regiones del Territorio Plurinacional, adopta un régimen de descentralización con Autonomías Territoriales.

II. La base política del reordenamiento territorial son las Autonomías Indígenas Originarias Campesinas, Departamentales y Municipales.

Artículo 136 (De la descentralización y Autonomías en general) 
I. Las Autonomías Indígenas Originarias Campesinas, Departamentales y Municipales son gobiernos descentralizados y con autonomía. La Constitución y la ley establecen las atribuciones, competencias, límites y relaciones de los gobiernos descentralizados y autónomos.

II. Las autonomías territoriales tendrán las siguientes facultades:

a) Facultad normativa administrativa. Es la capacidad para elaborar normas Administrativas en el marco de sus competencias, atribuciones y jurisdicción.

b) Facultad de gestión. Es aquella que sirve para ejecutar, planificar, controlar y Desarrollar sus competencias en el ámbito de su jurisdicción.

c) Facultad financiera. Es la Capacidad de generar y administrar sus propios recursos económicos y financieros y los que le sean transferidos por el Estado Unitario Plurinacional.

\section{Articulo. 137 (Carácter de las normas)}

Las normas administrativas pueden ser de carácter exclusivo, concurrente compartido:

- $\quad$ Exclusivas, en el ámbito de su competencia y jurisdicción;

- Concurrente (Reglamentarias), cuando las entidades autónomas reglamentan de forma concurrente sobre una misma materia o ejercen un sector de actividad en aquello que la ley faculta.

- Compartida, cuando las entidades autónomas acuerdan una norma común.

\section{Artículo 138}

Los Estatutos de las Autonomías Territoriales serán aprobados por Ley.

\section{Artículo 139}

El Estado Unitario Plurinacional se relacionará con las autonomías indígenas originarias campesinas, municipales y departamentales en igualdad de condiciones, atendiendo las necesidades particulares de cada entidad territorial autónoma y protegiendo los derechos inherentes a estas, para establecer un equilibrio en la asignación de recursos y en la transferencia de competencias.

\section{Articulo 140}

Todos los gobiernos descentralizados y autónomos tienen igual jerarquía constitucional $\mathrm{y}$ se rigen por los principios siguientes: 
a) Principio de Unidad. El régimen de descentralización y autonomías de los gobiernos autonómicos se constituye en la garantía de la unidad del Estado Unitario Plurinacional que ejerce el control y fiscalización sobre cada forma de gobierno descentralizado y autonómico.

b) Principio de Solidaridad. Se expresa en el acortamiento de las asimetrías económicas y de desarrollo existentes entre naciones, pueblos indígenas originarios y campesinos, regiones, departamentos y municipios a través de la distribución y redistribución solidaria de los bienes y productos sociales y en la complementación solidaria de sus economías para el desarrollo integral de todas las naciones y pueblos indígenas originarios y campesinos, las regiones, departamentos y municipios. Con el fin de asegurar un desarrollo equilibrado, el Estado Unitario Plurinacional Comunitario es el que define la política de los recursos estratégicos y establece los criterios de distribución y redistribución de los ingresos.

c) Principio del bien común. Es la premisa ética que armoniza los intereses particulares con los intereses colectivos, garantizando la unidad de la comunidad plurinacional en el marco de los principios de justicia, equidad y libertad.

d) Principio de reconocimiento. El reconocimiento de Autonomías Territoriales admite la legitimidad del derecho a la diferencia, sin afectar lo común que une al Estado Plurinacional y, al mismo tiempo, admite la administración de lo común sin desconocer la legitimidad del derecho a la diferencia.

e) Principio de igual jerarquía. Todos los gobiernos descentralizados y autónomos tienen igual jerarquía constitucional y no admiten subordinación jerárquica entre ninguno de los gobiernos descentralizados y autónomos.

f) Principio de Equivalencia. Todos los gobiernos descentralizados y autónomos reconocidas en esta Constitución tienen igual equivalencia en su articulación y relacionamiento entre sí y se relaciona en forma directa con el Estado Plurinacional

\section{CAPITULO II}

\section{DE LAS AUTONOMIAS INDIGENAS ORIGINARIAS Y CAMPESINAS}

\section{Artículo 141 (De las autonomías indígenas originarias y campesinas)}

I. La autonomía indígena originaria y campesina es el ejercicio del derecho al autogobierno que surge de la libre determinación de las naciones y pueblos indígenas originarios campesinos, que reconoce la Constitución del Estado Unitario Plurinacional Comunitario a las naciones y pueblos indígenas originarios y campesinos para la conformación de las Entidades Territoriales Indígenas; Municipios y Regiones Indígenas Originarias y Campesinas como gobiernos autónomos con las facultades de carácter ejecutivo, normativo, administrativo y jurisdiccional.

II. Se constituyen sobre la base de los territorios y comunidades indígenas originarias campesinas que tengan continuidad geográfica o no y/o a partir de los espacios geográficos ocupados por éstas que decidan constituirse como 
Entidades Territoriales Indígenas, Municipios Indígenas Originarios Campesinos o asociarse entre sí para constituir Regiones Indígenas Originarias Campesinas.

III. En los municipios donde exista presencia poblacional autoidentificada como indígena originaria campesina, cuando así lo decidan podrán transformarse en municipios indígenas originarios campesinos.

IV. La decisión de transformar el municipio intercultural en municipio indígena se adoptará a través de los mecanismos de consulta directa establecidos por esta Constitución y la ley.

V. Las Entidades Territoriales Indígenas, y los Municipios Indígenas Originarios y Campesinos podrán asociarse entre sí para conformar Regiones Indígenas Originarias Campesinas

VI. El gobierno de las autonomías indígenas, se ejerce a través de sus formas propias de organización y por medio de sus autoridades naturales recreadas funcional y convencionalmente para administrar el gobierno indígena autónomo, con base en la estructura siguiente:

a) En las Entidades territoriales indígenas originarias campesinas el gobierno autónomo se estructura con una Asamblea Territorial y una Autoridad Mayor, nominados con el nombre que corresponda a cada nación, pueblo o comunidad: Los representantes de la Asamblea Territorial y la Autoridad Mayor, se eligen, nominan o designan conforme a sus normas y procedimientos propios.

b) En los Municipios Indígenas Originarios Campesinos: el gobierno autónomo se estructura con una Asamblea Municipal y una Autoridad Mayor, nominados con el nombre que corresponda a cada nación, pueblo o comunidad: Los representantes miembros de la Asamblea Municipal y la Autoridad Mayor, se eligen, nominan o designan conforme a sus normas y procedimientos propios

c) En las Regiones Indígenas: El gobierno autónomo se estructura con una Asamblea Regional y Autoridad Mayor Regional, nominados con el nombre que decidan los habitantes de la región y representantes miembros de la Asamblea Regional y la Autoridad Mayor se eligen, nominan o designan conforme a normas y procedimientos propios.

\section{Art. 142 (Competencias y facultades de las autonomías indígenas originarias y campesinas)}

I. Las autonomías indígenas originarias y campesinas tienen autonomía, política,

administrativa, patrimonial, territorial y jurisdiccional y otras establecidas por esta

constitución y la ley, traducidas de la forma siguiente:

a) Autonomía política: Que implica las facultades de control de sus instituciones, conformar su gobierno autónomo; Elaborar y aprobar sus estatutos autonómicos; De elegir, nominar o designar a sus autoridades representativas para la conformación de 
su gobierno y para la designación y delegación de representantes ante las instancias, órganos y poderes del Estado y otros niveles de gobierno; Mantener o adecuar sus estructuras políticas y administrativas a las necesidades de gobierno de las entidades territoriales, municipios y regiones indígenas originarias y campesinas; Definición y aplicación de normas propias de gobierno, administración y control; Definición, implementación y ejecución de políticas, planes y programas, de salud, educativas, culturales, productivas, de desarrollo, acceso, uso y aprovechamiento de la tierra y los recursos naturales, de relacionamiento, tributarias y fiscales, en concordancia con las políticas del Estado Plurinacional

b) Autonomía Administrativa: La autonomía administrativa implica las facultades de Aplicar o adecuar sus normas propias de administración y definir su estructura administrativa; Administrar los recursos económicos y financieros propios y los asignados por los órganos y poderes del Estado y otras instancias de gobierno; Mantener o adecuar sus normas y mecanismos de planificación, ejecución, control y fiscalización administrativa, económica y financiera, en concordancia con las normas del Estado Plurinacional

c) Autonomía Patrimonial: la autonomía patrimonial, implica las facultades de administración, control, manejo y aprovechamiento de todos los recursos naturales, la biodiversidad, los conocimientos saberes, ciencia y tecnología y de cuanto recurso existente en sus territorios sea susceptible de aprovechamiento y valor económico, ecológico, cultural o religioso, y de los recursos económicos propios y asignados por los otros niveles de gobierno, en concordancia con el marco jurídico del Estado Unitario Plurinacional.

d) Autonomía Territorial y jurisdiccional: Implica las facultades de gestión, manejo, control y protección de sus territorios, el ejercicio de la jurisdicción indígena en la administración de justicia, según sus normas, autoridades y procedimientos propios

e) Otras Facultades autonómicas: Las autonomías indígenas originarias campesinas tienen las siguientes Competencias:

- Velar por el cumplimiento de esta Constitución y los Estatutos autonómicos.

- Elaborar y aprobar el Estatuto Autonómico o normas propias de organización y funcionamiento.

- Definir sus sistemas jurídicos, elegir autoridades y estructurar las formas de gobierno e instituciones para la gestión autonómica. Las autoridades de las autonomías indígenas originarias y campesinas tienen reconocimiento de orden constitucional y corresponden a cada pueblo y nación según sus propias normas y procedimientos, sin que se requiera ningún trámite adicional ante otra entidad del Estado Plurinacional.

- Establecer las reglas y mecanismos para el orden público en sus territorios, en concurrencia con el Gobierno Plurinacional.

- Definir, en coordinación con el sistema de orden público, la seguridad y justicia plurinacional, como las instituciones y mecanismos de control y policía.

- Expedir todo tipo de documentos y certificados relacionados con el ejercicio de sus competencias y sus derechos colectivos, como en todos los asuntos que considere de interés para el beneficio de sus comunidades. Estos documentos gozan de plena validez y no necesitan de certificación u homologación por otra autoridad. 
- Definir y normar internamente los mecanismos de consulta y/o veto frente a la exploración y explotación de recursos naturales no renovables, a través de las organizaciones genuinas, legítimas y representativas de las naciones y pueblos indígenas, originarios y campesinos, según los procedimientos correspondientes a cada cultura. La consulta tendrá las siguientes características: previa, obligatoria, de buena fe, informada y vinculante.

- Realizar el control fiscal de las inversiones y recursos públicos en sus territorios, de conformidad con las normas internas de los gobiernos autónomos y las leyes del Estado Plurinacional.

- Definir el presupuesto en coordinación con el Estado Unitario Plurinacional.

- Aprobar el plan de desarrollo.

- Generar su propia economía, recursos económicos, para la sostenibilidad en sus territorios.

- Realizar acuerdos de cooperación y alianzas con otros pueblos o entidades nacionales e internacionales para el desarrollo económico.

- Administrar los recursos económicos propios o provenientes del Estado Unitario Plurinacional $u$ otras fuentes de financiamiento.

- Definir la planificación y ejecución de su desarrollo económico, cultural y social acorde a la identidad y visiones propias desde una perspectiva intercultural. Para ello aprueba su propio plan de desarrollo y define su presupuesto.

- Generar su propia economía, recursos económicos e instituciones que considere necesarias para la sostenibilidad en sus territorios.

- Realizar acuerdos de cooperación y alianzas con otros pueblos o entidades nacionales e internacionales para el desarrollo económico, político, social, cultural y espiritual para el disfrute de los derechos y libertades.

- Administrar los recursos económicos propios o provenientes del Estado Plurinacional u otras fuentes de financiamiento.

- Definir normas y formas de gestión, administración y control del territorio.

- Definir normas de protección medioambiental y regular políticas sobre esta materia.

- Regular y velar por la protección, conservación y aprovechamiento de recursos medio ambientales o de biodiversidad en sus territorios, en coordinación con el Gobierno Plurinacional.

- Administrar, promover y garantizar el uso y manejo sustentable de los recursos naturales renovables de acuerdo a sus normas propias, en concurrencia con el Gobierno Plurinacional para los recursos naturales no renovables.

- Gestionar y administrar las tierras colectivas y recursos de propiedad comunal, de acuerdo con sus normas y modalidades de transmisión de derechos.

- Ejercer el control del territorio y los recursos naturales, de conformidad con el derecho a mantener y fortalecer su propia relación espiritual y material con sus tierras, territorios, aguas y otros recursos que tradicionalmente han poseído, ocupado o utilizado $\mathrm{y}$, a asumir las responsabilidades que a ese propósito corresponden respecto de las generaciones venideras. 
- Participar en la toma de decisiones sobre todo proceso de exploración, explotación, industrialización y comercialización de los recursos naturales no renovables del país que se encuentren en sus territorios.

- Regular el registro y resguardo de la propiedad intelectual colectiva sobre sus recursos naturales genéticos y culturales.

- Velar por la plena vigencia de la administración de justicia en el ámbito de sus territorios, pueblos y en culturas.

- Administrar justicia de acuerdo con sus sistemas jurídicos y a través de sus autoridades propias, mecanismos y procedimientos propios de cada cultural, en el marco del respeto a los derechos humanos individuales y colectivos. La Ley compatibilizará estas funciones con el sistema judicial Plurinacional y otros órganos del poder público.

- Regular, conocer y resolver todos aquellos casos relacionados con la prevención, manejo y transformación de conflictos. Asimismo, tomar y ejecutar las decisiones en todas las materias que consideren pertinentes. Establecer los mecanismos suficientes para hacer cumplir las decisiones fijadas por la justicia comunitaria y los derechos de los pueblos y naciones indígenas originarias campesinas.

- Planificar, prestar, administrar y controlar el sistema de educación, salud, comunicación y otros, de acuerdo a prácticas y visiones culturales propias. Para ello deberá coordinar con las demás entidades y políticas del Estado Plurinacional.

- Definir los contenidos y programas educativos, en coordinación con el Gobierno Plurinacional.

- Crear sus propias instituciones para la prestación de servicios de educación, salud, comunicación y otros que se definan a través de sus normas internas, en concordancia con la Constitución y las leyes. El gobierno plurinacional garantiza y contribuye a la formación de recursos humanos comunitarios para la gestión y el control del territorio autónomo.

- Promover y controlar el acceso a los medios de comunicación, radiales, televisivas y de prensa, para el desarrollo cultural de los territorios.

- Establecer, regular y controlar el sistema educativo o de instrucción pública en sus territorios, así como las instituciones y el personal docente, de conformidad con sus instituciones propias y métodos culturales de enseñanza y aprendizaje.

- Definir los contenidos y programas educativos, en coordinación con el Gobierno Plurinacional.

- Establecer la oficialidad de los idiomas en los territorios de los pueblos y su obligatoriedad de cumplimiento a través de la jurisdicción y las autoridades del Gobierno Autónomo.

- Regular y proteger la propiedad intelectual colectiva sobre sus recursos naturales genéticos y culturales, a través de mecanismos para el registro, resguardo y otros que se consideren necesarios para la protección del patrimonio cultural.

- Mantener, proteger y desarrollar las manifestaciones pasadas, presentes y futuras de sus culturas en todos los ámbitos, incluyendo el ejercicio del derecho a la 
restitución de los bienes culturales, intelectuales, religiosos y espirituales de los que han sido privados.

- Establecer los procesos de certificación y carnetización de acuerdo al derecho a la identidad, a los nombres propios y a la ciudadanía plurinacional.

- Definición y aplicación de normas para asegurar el acceso y estabilidad en el trabajo.

- Promover en sus territorios la equidad social y la igualdad de los derechos de la mujer, adoptando medidas para prevenir, sancionar y eliminar cualquier forma de discriminación.

- Participación directa de los pueblos indígenas, originarios y campesinos en los procesos de gestión pública, generando espacios institucionales que permitan su plena incorporación en los niveles de administración por fuera de su territorio.

II. Las facultades descritas anteriormente no implican la negación del ejercicio por parte de los gobiernos autónomos indígenas originarios campesinos de otras facultades que no correspondan a otros poderes del Estado Unitario Plurinacional Comunitario y de las que se les reconocen en esta constitución, las leyes y convenios e instrumentos internacionales.

\section{Art. 143 (Asignación de recursos a las autonomías indígenas originarias y campesinas)}

En la asignación de recursos económicos y financieros a las autonomías indígenas, primará el principio de discriminación positiva, tomando en cuenta el índice de desarrollo humano, la vulnerabilidad social, los grados de pobreza y sub desarrollo, la marginalidad, carencia o insuficiencia de infraestructura básica, la ubicación geográfica alejada de los centros urbanos, etc. De tal forma que los recursos asignados vayan acortando las asimetrías económicas y de desarrollo

\section{CAPITULO III \\ AUTONOMIAS DEPARTAMENTALES INTERCULTURALES}

\section{Artículo 144 (Forma de gobierno)}

En los departamentos: El gobierno se estructura con una Asamblea Departamental y un Prefecto. La Asamblea Departamental esta compuesta por representantes de las naciones y pueblos indígenas originarios y campesinos de cada departamento elegidos, designados o nominados según sus normas propias, y por representantes de la población intercultural elegidos por sufragio universal . El Prefecto se elige por sufragio universal $\mathrm{y}$ voto directo.

\section{CAPÍTULO IV}




\section{AUTONOMÍAS MUNICIPALES INTERCULTURALES}

\section{Artículo 145 (Municipio Interculturales)}

Son Municipios interculturales, los actuales municipios

\section{Artículo 146 (Forma de gobierno)}

El gobierno municipal se estructura con un Concejo Municipal y el Ejecutivo Municipal representado por el Alcalde, quienes se eligen por sufragio universal directo.

\section{Artículo 147 (Competencias)}

Son competencias concurrentes con el Gobierno Plurinacional todas aquellas relacionadas con el desarrollo económico, social, salud, educación, riego, infraestructura y medio ambiente. Las competencias en materia educativa serán coordinadas con los gobiernos autónomos locales.

\section{Artículo 148 (Competencias del Gobierno Plurinacional)}

Las competencias del nivel de gobierno Plurinacional garantizarán la unidad y la integridad territorial del Estado Plurinacional y tendrá las siguientes competencias privativas:

Moneda,

Banco Central, finanzas y seguros,

Comercio exterior,

Fuerzas Armadas,

Policía,

Aduanas,

Relaciones internacionales,

Legislación,

Titularidad y gestión de los recursos naturales energéticos estratégicos,

Política sobre distribución y redistribución de la tierra

Política fiscal, supervisión y control sobre el sistema financiero,

Ciencia y tecnología,

Los asuntos relativos con la nacionalidad, las nacionalidades y la ciudadanía,

Regulación, control y políticas sobre migración,

Política del endeudamiento público, (ver régimen económico)

Régimen tributario de alcance nacional,

Normas básicas del sistema de administración y control gubernamental, de cumplimiento obligatorio por los tres niveles de gobierno,

Sistema nacional de planificación,

Transporte terrestre, aéreo y fluvial. Red fundamental de carreteras, aeropuertos, ferrocarriles y los puertos fluviales y lacustres.

Todas aquellas que no estén expresamente establecidas en los otros niveles de gobierno 


\title{
PARTE CUARTA
}

\section{GESTIÓN DE LOS RECURSOS NATURALES, MEDIO AMBIENTE, TIERRA, TERRITORIO Y DESARROLLO RURAL INTEGRAL}

\author{
TÍTULO PRIMERO
}

\author{
DE LOS RECURSOS NATURALES \\ CAPÍTULO I \\ DISPOSICIONES GENERALES
}

\section{Artículo 149 (Recurso naturales)}

Son recursos naturales el suelo, el subsuelo con todas sus riquezas mineralógicas, los hidrocarburos, los bosques, los ecosistemas con todos los elementos sociales, económicos, culturales y espirituales que los integran, los recursos hídricos, la diversidad biológica, así como el espacio aéreo, el espectro electromagnético y todas las fuerzas físicas susceptibles de aprovechamiento que se encuentren en el espacio territorial Boliviano.

\section{Artículo 150 (Dominio y Propiedad de los Recursos Naturales)}

Los recursos naturales son de dominio y propiedad de las naciones y pueblos indígenas originarios campesinos y de la población intercultural que conforman la población del Estado Unitario Plurinacional Comunitario, sobre los cuales ejercen plena soberanía.

\section{Artículo 151 (Gestión y Administración)}

El Estado Unitario Plurinacional Comunitario, ejerce directamente las facultades inherentes a la propiedad, gestión, administración y explotación de los recursos naturales que no pertenezcan a las naciones, pueblos y comunidades indígenas originarias y campesinas. Los beneficios y utilidades provenientes del proceso de exploración, explotación, industrialización y comercialización de los recursos naturales serán distribuidos y redistribuidos en favor de toda la población del Estado Unitario Plurinacional Comunitario, fundado en los principios de equidad, solidaridad, complementariedad y los demás principios que esta Constitución establece.

\section{Artículo 152 (Protección y Conservación)}

El Estado Plurinacional Unitario garantiza y promueve la protección, conservación y preservación de los recursos naturales en corresponsabilidad con las naciones, pueblos y comunidades indígenas originarias campesinas y la población intercultural en general. 
En las fronteras, se establecerán controles especiales para el cumplimiento efectivo de este propósito.

\section{Artículo 153}

Toda utilización de los recursos naturales al interior del territorio plurinacional, está sujeta a procesos de consulta previa, libre, informada y obligatoria a las poblaciones afectadas, garantizando procesos de prevención y control socioambiental $\mathrm{y}$ promoviendo la conservación de los ecosistemas.

\section{CAPÍTULO II \\ RECURSOS NATURALES NO RENOVABLES}

\section{Artículo 154}

Son recursos naturales no renovables los minerales y los hidrocarburos en cualquier estado en el que se encuentren, los que no podrán ser transferidos, enajenados ni embargados bajo ningún título, por su carácter imprescriptible, inalienable y de reserva estratégica de todos los bolivianos.

\section{Artículo 155}

El Estado Unitario Plurinacional Comunitario ejerce la propiedad, la gestión, administración, explotación y conservación de todos los recursos naturales no renovables,

Las facultades del Estado Unitario Plurinacional Comunitario inherentes al ejercicio de la propiedad, gestión, administración y explotación de los recursos naturales no renovables que se encuentren en tierras, territorios y comunidades indígenas, originarias y campesinas, o en áreas susceptibles de afectación del hábitat de éstos, solamente podrá ser realizadas con previo consentimiento libre, informado y con carácter vinculante de los pueblos interesados.

\section{Articulo 156}

Las naciones, pueblos y comunidades indígenas originarias campesinas participan en forma directa, real y efectiva en la gestión, administración, toma de decisiones y beneficios provenientes del proceso de exploración, explotación, industrialización y comercialización de los recursos naturales no renovables expresados en regalías y utilidades en los territorios donde se encuentren estos recursos.

\section{Artículo 157}

Las actividades de exploración, explotación, transporte, industrialización y comercialización de los hidrocarburos y minerales serán realizadas de manera directa por el Estado Unitario Plurinacional, a través de una empresa pública o mediante 
empresas de economía mixta con participación mayoritaria del Estado Plurinacional Unitario y con control en la administración. Ningún acto jurídico podrá conferir la propiedad de este recurso, los mismos que estarán viciados de nulidad. Mediante Ley se establecerá un organismo público que tendrá atribuciones de regulación y control de estas actividades con participación social.

\section{CAPÍTULO III \\ RECURSOS NATURALES RENOVABLES}

\section{Artículo 158}

Son recursos naturales renovables, la tierra y la biodiversidad con todos los elementos que la componen.

\section{Artículo 159}

I. El Estado Unitario Plurinacional Comunitario ejerce la propiedad, la gestión, administración, explotación y conservación de todos los recursos naturales renovables, que no se encuentren en las tierras, territorios y comunidades de las naciones y pueblos indígenas originarios campesinos. Al Estado Unitario Plurinacional Comunitario le corresponde normar y regular el uso, aprovechamiento, gestión y manejo de los recursos naturales renovables y el acceso a los mismos.

II. Los recursos naturales renovables que se encuentran dentro de las tierras, territorios y comunidades de las naciones y pueblos indígenas, originarios y campesinos, son propiedad de los mismos y se rigen por sus instituciones, normas, y sistemas jurídicos propios, en concordancia y observancia de lo dispuesto en esta constitución y la ley.

\section{CAPÍTULO IV RECURSOS HÍDRICOS}

\section{Artículo 158}

Los recursos hídricos en todos sus estados, superficiales y subterráneos, constituyen recursos finitos, vulnerables, fundamentales para la vida, constituyendo por tanto recursos estratégicos de propiedad de todos los bolivianos. Son inalienables, inembargables y tanto ellos como sus servicios no podrán ser entregados en concesión. 
El acceso al recurso agua es un derecho humano en el marco de la soberanía del Estado Unitario Plurinacional. Es deber del estado promover el uso y acceso al agua sobre la base de principios de solidaridad, complementariedad, reciprocidad, equidad, diversidad y sostenibilidad.

\section{Artículo 160}

El Estado Unitario Plurinacional protege y garantiza el uso prioritario del agua para la vida. La Ley establecerá las condiciones y limitaciones de todos los usos del agua.

\section{Artículo 161}

El Estado Unitario Plurinacional, regula, protege y planifica el uso de los recursos hídricos, la gestión de cuencas y la provisión del agua para consumo humano a través de entidades públicas con control y participación social

\section{Artículo 162}

La Constitución Política del Estado reconoce, respeta y protege los usos y costumbres sobre el agua de las comunidades y organizaciones indígenas, campesinas y originarias.

\section{Artículo 163}

En todo acuerdo, convenio o norma internacional que suscriba el Estado Unitario Plurinacional sobre recursos hídricos, la gestión y los servicios asociados a éstos, se deberá garantizar los derechos de todos los bolivianos y la soberanía boliviana. Así mismo, el Estado Unitario Plurinacional establecerá una política exterior de aguas, priorizando el interés nacional y el principio del agua como derecho humano por encima de cualquier interés comercial. Se prohíben acuerdos y tratados de libre comercio que comprometan los recursos hídricos y sus servicios.

\section{CAPÍTULO V \\ BIODIVERSIDAD Y MEDIO AMBIENTE}

\section{$[\cdots]$}

$[\ldots]$

\section{Artículo 172}

Antes de iniciarse cualquier obra o actividad pública o privada que sea susceptible de generar alteración sobre el medio ambiente, deberán realizarse estudios participativos de evaluación ambiental, socioeconómica, cultural y comunitaria. 
En caso que exista riesgo inminente de que se produzcan daños ambientales, el Estado Plurinacional Unitario deberá adoptar de manera inmediata todas las acciones necesarias para prevenir y precautelar la conservación y calidad de los recursos naturales en riesgo que pudieren resultar afectados.

$[\ldots]$

\section{CAPITULO VI \\ TIERRA Y TERRITORIO}

\section{Artículo.-}

La tierra es patrimonio social, cultural y económico del Estado Plurinacional Unitario y estratégica para el desarrollo integral de la población.

\section{Artículo.-}

Las tierras fiscales serán dotadas gratuitamente y a título colectivo, para indígenas originarios y campesinos que no poseen tierras o la posean insuficientemente, en el marco de una política estatal, que atienda las realidades ecológicas, geográficas, así como las necesidades poblacionales, sociales, culturales y económicas, de acuerdo a las premisas del desarrollo rural sustentable.

\section{Artículo.-}

El Estado Plurinacional Unitario garantiza, protege y fomenta de manera preferente las diferentes formas propiedad colectiva - comunitaria y asociada de la tierra.

Artículo.- La pequeña propiedad individual cumple con una función social en los casos establecidos en la Ley y son imprescriptibles, indivisibles, constituyen patrimonio familiar inembargable y están exentas del pago de impuestos.

\section{Artículo.-}

El Estado garantiza la conservación de la propiedad privada agraria, siempre que cumpla la función económica social y no perjudique el interés colectivo. Sus titulares deberán producir para el mercado, generar fuentes de empleo y procesos de desarrollo tecnológico en beneficio de la sociedad.

\section{Artículo.-}

Son mecanismos de recuperación de tierras al dominio patrimonial del Estado Plurinacional Unitario la reversión y la expropiación de tierras.

La reversión procederá en propiedades que no cumplen parcial o totalmente la función económica y social.

- La expropiación procederá por causal de utilidad pública y en los casos de 
reconstitución de territorios indígenas y originarios afectados por derechos de particulares no indígenas.

- $\quad$ Procede también la expropiación por causal de reagrupamiento y redistribución de tierras para dotación a comunidades indígenas, originarias y campesinas sin tierras.

\section{Artículo.-}

El Estado Plurinacional Unitario prohíbe el latifundio, que es la propiedad agraria de gran extensión, variable según su situación geográfica, que permanece improductiva o es trabajada deficientemente con un sistema extensivo, con instrumentos y medios técnicos inapropiados o rige un sistema servidumbral de relación laboral, trabajo forzoso, peonazgo por deudas y/o esclavitud de familias o personas cautivas en el área rural, si se practica renta fundiaria mediante el arrendamiento o aparcería; $u$ otras modalidades equivalentes.

En cualquiera de estos casos, la autoridad competente, procederá a la restitución ipso facto, caducando cualquier derecho sobre las tierras mantenidas en esa condición, las mismas que pasarán al patrimonio del Estado Plurinacional Unitario para su redistribución de acuerdo a lo establecido en este capítulo.

Una norma especial establecerá las medidas necesarias para evitar la concentración y acaparamiento de tierras, así como la clasificación y extensiones máximas de la propiedad agraria.

\section{Artículo.-}

Las comunidades campesinas están asentadas sobre tierras dotadas por el Estado Plurinacional Unitario y otorgan a sus titulares la propiedad colectiva sobre las mismas. Son inalienables, imprescriptibles, irreversibles, indivisibles e inembargables.

\section{Artículo.-}

Son territorios indígenas los espacios geográficos que constituyen el hábitat de las naciones y pueblos indígenas y originarias a las cuales han tenido tradicionalmente acceso y donde mantienen y desarrollan sus propias formas de organización económica, social y cultural, de modo que aseguran su vida y su desarrollo.

\section{Artículo.-}

I. El Estado Plurinacional Unitario reconoce la preexistencia de las nacionalidades, pueblos indígenas y originarios que habitan el territorio nacional y sus territorios ancestrales como territorios indígenas, así como sus sistemas económicos, valores culturales, medicina tradicional, sistema de justicia, lenguas originarias e instituciones.

II. Se reconocen los derechos colectivos preexistentes de las nacionalidades, pueblos indígenas y originarios sobre sus territorios. Corresponde al Estado Plurinacional Unitario normar mediante Ley la formalización de estos derechos garantizando el acceso inmediato a su hábitat, preservando su continuidad geográfica. Se tomará especial atención a los pueblos indígenas en estado de aislamiento o en contacto inicial.

III. Los derechos patrimoniales de los pueblos indígenas y originarios sobre sus 
territorios son inalienables, indisponibles, irrevisables, inembargables e imprescriptibles y otorgan a sus titulares el derecho propietario colectivo sobre los recursos naturales renovables existentes en ellos así como la facultad de disponer internamente el uso, acceso y aprovechamiento del hábitat que lo compone de acuerdo a sus usos y costumbres, los que tendrán que concordarse con la legislación nacional.

\section{$[\ldots]$}

\section{Artículo.-}

Los recursos forestales son de dominio originario del Estado Plurinacional Unitario. En los territorios y comunidades indígenas, originarios y campesinos los bosques son de propiedad de pueblos indígenas, originarios y campesinos.

\section{Artículo.-}

El Estado Plurinacional Unitario establecerá políticas de fomento e incentivo para un aprovechamiento responsable y generación de procesos de industrialización, con la finalidad de generar mayor valor agregado a la producción forestal nacional sustentable.

\section{Artículo.-}

El Estado Plurinacional Unitario generará las condiciones para el desarrollo de un mercado de productos forestales alternativos fomentando la producción colectiva para comunidades indígenas originarias y campesinas, valorando los elementos sociales y culturales de las mismas.

\section{CAPÍTULO VII DESARROLLO RURAL INTEGRAL}

Artículo.- Esta Constitución prohíbe la utilización de cualquier agroquímico susceptibles de causar daños a la salud, el medio ambiente u otros asociados a productos transgénicos. Se establecerán controles y regulaciones específicos en el uso de productos químicos en procesos productivos.

Artículo.- I. El Estado Plurinacional Unitario promoverá, incentivará y fomentará el desarrollo rural sustentable de pequeños productores, pueblos indígenas, originarios y campesinos con políticas públicas orientadas a fomentar la producción local diversificada de productos alimenticios adaptados al entorno socioeconómico y natural, potenciando la inversión para la infraestructura productiva, proveyendo de asistencia técnica subvencionada, dotando de capacitación y formación de recursos humanos y la promoviendo la investigación e innovación tecnológica.

II. Como parte de una política nacional de desarrollo e incentivos a la producción, se garantizará el acceso al sistema financiero para créditos de fomento a pequeños productores, asociaciones comunitarias, organizaciones económicas indígenas, originarias, campesinas y cooperativas.

III. El desarrollo rural sustentable se fundamenta en la recuperación y conservación de 
las semillas nativas, la conservación y manejo sustentable de suelos de acuerdo a su vocación de uso mayor y la implementación de sistemas de riego.

IV. Se garantizarán condiciones adecuadas para la comercialización, priorizando los mercados con precio justo para la producción agropecuaria en el mercado interno y externo.

V. Se creará un seguro agrario rural para paliar situaciones de emergencia en casos de desastres naturales que afecten a pequeños productores indígenas o campesinos. Una ley establecerá su implementación. 


\section{CAPITULO xx}

\section{DE LA ORGANIZACIÓN ECONOMICA.}

Artículo

El régimen económico se basa fundamentalmente en una Economía Social Comunitaria, que tiene como objetivo fundamental el VIVIR BIEN de toda la población, los pueblos, naciones y las culturas que forman el Estado Unitario Plurinacional Comunitario y que se basa en principios de solidaridad, transparencia, eficiencia, sustentabilidad, reciprocidad, complementariedad, igualdad, justicia, equidad de genero y distributiva, evitando la concentración de la riqueza.

Artículo

I. El Estado reconoce seis formas de organización económica:

a. La pequeña producción urbana y rural que opera con racionalidad, en base a lógicas de producción e intercambio propias de la economía comunitaria.

b. La economía comunitaria que agrupa las organizaciones económicas campesinas, indígenas, originarias, y asociaciones de pequeña producción urbana y rural.

c. La economía pública estatal.

d. La economía mixta

e. La empresarial moderna capitalista

f. La cooperativa

II. El Estado Unitario Plurinacional Comunitario respeta y protege la existencia de las seis formas de organización económica; promoviendo el intercambio económico justo y equitativo entre las mismas.

Art.

El Estado reconoce, respeta, protege y promueve todas las formas e instituciones de organización económica propias de las sociedades comunitarias en la que se combina la participación individual con la colectiva, tanto en la producción como en la distribución del producto social según los usos y costumbres de cada región.

Articulo

I. El Estado reconoce, respeta y protege la iniciativa privada y la retribución justa del capital invertido, siempre y cuando contribuya al desarrollo económico-sociocultural del país, y no ponga en riesgo la independencia económica ni la soberanía del Estado, estableciendo relaciones económicas con empresas y Estados extranjeros en condiciones, respeto mutuo y equidad

II. La economía privada debe ser ambientalmente sustentable, fuente de trabajo digno, con precio justo, sin discriminación de ninguna índole, y no agravará desigualdades ni aumentará la pobreza. 
Articulo

I. El Estado, mediante sus instituciones planifica, regula, controla, fiscaliza y participa activamente en la economía del país. convirtiendose en un vigoroso actor económico que orienta sus acciones a favorecer el fortalececimiento de la economía comunitaria y la pequeña producción urbana y rural, sin afectar la economía empresarial privada

II. El desarrollo económico y social se rige por la planificación del Estado establecido con participación y consulta ciudadana.

III. Estado debe promover la articulación vertical y horizontal de la economía además de aprovechar las ventajas de la heterogeneidad estructural productiva para fortalecer la capacidad competitiva del país en el mercado internacional.

$[\ldots]$

\title{
SECCIÓN
}

\author{
DE LO FISCAL, FINANCIERO Y MONETARIO
}

$[\ldots]$

$[\ldots]$

\section{SECCIÓN}

\section{DE LAS POLITICAS ECONOMICA, FISCALES Y FINANCIERA}

Artículo XX

El Estado Plurinacional promueve políticas contra las desigualdades y otras formas de exclusión social y económica promoviendo la erradicación la pobreza en sus múltiples dimensiones, el trabajo digno, justa retribución y precios justos para los productores. Art.xx.-

I. El Estado establecerá la política comercial con el objetivo de que la oferta de bienes y servicios tienda a cubrir las necesidades básicas internas otorgando prioridad a los bienes y servicios producidos en Bolivia.

II. El estado fomentará las capacidades económicas, técnico humanas y tecnológicas a la pequeña producción urbana y rural, comunitarias y cooperativas.

Art. Xx El Estado fomentará y promocionará la creación de organización económicas productivas, que enfaticen un modelo de producción con base social amplia y participativa.

Art. Xx

El estado mediante ley, establecerá mecanismos de asignación directa de recursos económicos a las comunidades, para el lograr un desarrollo equilibrado de los habitantes del país. 


\section{SECCIÓN \\ COMERCIO INTERNACIONAL}

Art.xx.-

I El Estado Plurinacional establecerá relaciones comerciales y diplomáticas con todos los países del mundo al margen de sus sistemas políticos económicos y culturales; debiendo todo acuerdo internacional y en particular aquellos de índole comercial, negociarse de manera pública y transparente, subordinados siempre a la soberanía nacional y a los intereses del pueblo boliviano.

$[\ldots]$

$[\ldots]$

\section{DE LA ORGANIZACIÓN SOCIAL}

\section{CAPITULO xx \\ EDUCACIÓN Y CULTURAS}

\section{EDUCACIÓN}

Art.

I. La educación es liberadora, comunitaria, descolonizadora, productiva territorial, universal y gratuita. Fomenta el desarrollo de la conciencia crítica, es transformadora de las estructuras económicas, sociales, culturales, políticas e ideológicas; por lo que revitaliza el proceso de reconstitución y autodeterminación de los naciones indígenas originarios en el marco de la Unidad y la interculturalidad del Estado Plurinacional.

\section{$[\ldots]$}

Art.

I. Es prioridad del Estado Plurinacional, garantizar el carácter intracultural, intercultural, pluricultural y plurilingüe de la educación como su pilar fundamental en todos sus niveles y modalidades, conforme a la diversidad cultural y lingüística del país, a partir de la lengua indígena originaria como la principal y el castellano como lengua de vinculo intercultural.

El Estado debe garantizar la construcción y aplicación de pedagogías y currículos propios para cada Nación indígena originaria basado en revalorizando sus saberes y conocimientos y fomentando una educación desde la familia y la comunidad, para luego proyectar a la apropiación cultural selectiva de otros saberes y conocimientos universales.

El Estado Plurinacional a través del órgano competente ejecutivo aplicara políticas y programas para recuperar, fortalecer y desarrollar las lenguas oficiales, en todos los niveles y modalidades de la Educación. 
Art. El sistema educativo potencia, recrea y desarrolla la cultura, la sabiduría, ciencia y tecnología, la lengua propia de las naciones indígenas originarias que se interrelacionan y conviven en igualdad de condiciones y oportunidades, valoración y respeto recíproco entre las culturas del Estado Plurinacional y del mundo.

Art. El Estado Plurinacional garantiza una educación integral de calidad, terminal y proyectiva, permanente, en igualdad de condiciones y oportunidades, que es obligatoria, universal, igualitaria, participativa, comunitaria, espiritual, artística, técnica, científica y productiva en todas sus modalidades y niveles; así mismo, es descentralizada autónoma en su gestión institucional y curricular, desde el nivel local del ordenamiento políticoadministrativo territorial del Estado Plurinacional y al en concordancia con ejercicio de las autonomías territoriales indígenas originarias y campesinas.

Art. La educación es un derecho irrenunciable de las naciones y pueblos indígenas originarias, campesinas y afro descendientes, así como de todos los sectores sociales del país; por tanto, es prioridad del Estado garantizar el acceso a la educación y $\underline{\text { u }}$ certificación gratuita para todos los bolivianos, desde el nivel inicial hasta el nivel superior, en igualdad de condiciones de acuerdo al contexto geográfico, social, cultural y lingüístico de cada nación indígena originaria.

Art. La educación contribuye al fortalecimiento del carácter plurinacional y unitario del Estado a partir de la profundización de la democracia participativa comunitaria, del respeto y el fortalecimiento de las normas propias de las naciones indígenas originarias y campesinos y la gestión autónoma de sus territorios, a partir del manejo sustentable de los Recursos Naturales.

Art. La educación es participativa comunitaria y democrática en todos los niveles por lo que el Estado garantiza la participación con poder de decisión de los actores vinculados directamente a la gestión y los procesos educativos, a través de sus organizaciones legal y legítimamente constituidas en la definición de políticas educativas pertinentes a la realidad y la diversidad del Estado Plurinacional.

\section{$[\ldots]$}

Art. La educación pública es pluralista, por lo que el Estado garantiza la libertad de religión y de culto, de espiritualidad y cosmovisión, en el sistema educativo plurinacional.

Art.

La educación superior está conformada por universidades, institutos de la lengua y cultura, institutos superiores de formación docente, institutos técnicos y tecnológicos con enfoque intracultural, intercultural y plurilingüe, que garantice el desarrollo social, cultural y productiva, acorde a los adelantos tecnológicas mundiales.

Las Universidades deben producir ciencia en todos los ámbitos y ramas del conocimiento a partir de la realidad plurinacional y combinando los saberes de las naciones indígenas originarias y campesinas con otros conocimientos.

\section{$[\ldots]$}

Art. 
I. Las universidades públicas tienen carácter pluricultural, intercultural y plurilingüe son autónomas e iguales en jerarquía, sujetas a la participación y control social de las organizaciones indígenas originarias, campesinas y populares. Además se sujetan al órgano nacional de fiscalización.

$[\ldots]$

IV La universidad pública debe garantizar la diversificación curricular y desconcentración de unidades académicas en correspondencia con las necesidades e intereses de las naciones indígenas originarias y con criterios de cobertura regional, a través de un plan nacional de educación superior, con la participación de todos los sectores sociales.

$[\ldots]$

Art. El Estado plurinacional promoverá la creación de universidades indígenas originarias con identidad, Institutos Superiores, diseñadas por regiones, desde la participación y la gestión comunitaria, en correspondencia con la vocación productiva de los territorios.

\section{$[\ldots]$}

\section{CAPITULO II CULTURA}

Art. La cultura es un principio de vida y práctica social permanente, que determina la identidad de cada pueblo, nuestra identidad, teniendo sus raíces en el conocimiento acumulado y recibiendo las contribuciones del exterior crítica y creativamente para revitalizar su nuestro presente en el marco de la unidad del estado plurinacional.

Art. El estado promueve, fomenta y garantiza, las condiciones, instrumentos legales, medios y presupuestos necesarios y suficientes para el desarrollo de las culturas a través del sistema educativo plurinacional, orientado al desarrollo de las lenguas, la investigación de las historias de las naciones indígenas originarias y campesinos, el desarrollo de las ciencias, las cosmovisiones propias, las tecnologías y las artes propias.

$[\ldots]$

\section{CAPITULO III \\ CIENCIA Y TECNOLOGÍA}

$[\ldots]$

\section{CAPITULO IV COMUNICACIÓN}


Art. El estado garantiza y desarrolla sistemas de comunicación social y de servicio público, para fortalecer la integración social en el estado plurinacional.

Art. El estado fortalece y promueve medios de comunicación comunitarios con control social: radios, medios audiovisuales y escritos para las naciones indígenas originarias y campesinas garantizando el acceso universal a la información.

$[\ldots]$

\section{CAPITULO V}

DEPORTES

$[\ldots]$

CAPITULO VI

TRABAJO, EMPLEO Y SEGURIDAD SOCIAL

TRABAJO

$[\ldots]$

EMPLEO

$[\ldots]$

$[\ldots]$

CAPITULO VII

SEGURIDAD INDUSTRIAL

$[\ldots]$

CAPITULO VIII

SINDICALIZACION

$[\ldots]$

CAPITULO IX

COOPERATIVA

$[\ldots]$

CAPITULO $\mathrm{X}$

SALUD

Art. El Servicio de Salud se organiza en el ámbito comunitario, en función al nuevo ordenamiento político administrativo del país. Este servicio se planificará y administrará con los pueblos indígenas y sus organizaciones, debiendo tomar en cuenta sus condiciones económicas, geográficas, sociales, lingüísticas y culturales, así como sus métodos de prevención, prácticas curativas y medicina tradicional.

$[\ldots]$

Art. El servicio de salud es intercultural, considerando en igualdad de jerarquía a la 
medicina tradicional y la occidental, lo cual se reflejará en la creación de unidades y proveedores de salud en todo el ámbito nacional. El Estado promoverá el respeto, el uso y la investigación de la medicina tradicional.

\section{CAPITULO XI}

\section{SEGURIDAD SOCIAL}

$[\ldots]$

\section{CAPITULO XII}

FAMILIA

\section{$[\ldots]$}

$[\ldots]$ 
Anexo 3

Documento - versão sintetizada pela OSAL-CLACSO, 2007.

Propuesta de las Organizaciones Indígenas, Originarias, Campesinas y de Colonizadores hacia la Asamblea Constituyente

Sucre, 5 de agosto de 2006

\section{Presentación}

El 13 de mayo de 2002 marca un hito histórico en el país cuando los excluidos de siempre iniciamos una marcha me- morable desde la ciudad de Santa Cruz hacia La Paz, sede de gobierno, con una demanda que no sólo interesaba a los campesinos indígenas originarios sino a toda la población del país: la convocatoria a la ASAMBLEA CONSTITUYENTE para refundar Bolivia.

En este marco, de manera sectorial las organizaciones campesinas, indígenas, originarias y de colonizadores de Bolivia empezamos procesos de elaboración colectiva de propuestas para una nueva Constitución Política del Estado, que incluya nuestros derechos y nuestra visión para la cons- trucción de un nuevo país.

A partir de la aprobación y promulgación de la Ley Especial de Convocatoria a la Asamblea Constituyente, en el mes de marzo de 2006, comenzamos de manera intensa un proceso de convergencia entre las organizaciones campesinas, indígenas, originarias y de colonizadores para construir de manera colectiva una sola propuesta de consenso. Con este fin, desde el mes de abril, hemos realizado una serie de encuentros nacionales en Cochabamba, Santa Cruz y La Paz, que culmina en una gran Asamblea Nacional, en la ciudad de Sucre, celebrada entre el 3 y 5 de agosto del presente año ${ }^{2}$.

La unidad del movimiento campesino, indígena, originario y de colonizadores es nuestro pilar fundamental para mostrarle al país que nuestra presencia es innegable e importante en el tratamiento de los grandes temas nacionales.

En este documento presentamos la "PROPUESTA PARA LA NUEVA CONSTITUCIÓN POLÍTICA DEL ESTADO” de las Organizaciones Indígenas, Originarias, Campesinas y de Colonizadores aprobada por Consenso en la gran Asamblea Nacional y que es entregada hoy, 5 de agosto de 2006, como mandato a nuestros Constituyentes, y presentada para el debate a la Asamblea Constituyente, al gobierno nacional y al pueblo boliviano. Convocamos a que otras organizaciones sociales se sumen a esta propuesta para la construcción de un Estado Plurinacional Unitario.

Nuestra tarea no ha concluido, el reto ahora es enriquecer nuestra propuesta en el debate, generar alianzas con organizaciones sociales de los sectores urbanos y 
rurales; ejercer el derecho a la participación, vigilancia y movilización social en la búsqueda del bienestar general y una convivencia pacífica y solidaria entre todos los bolivianos y bolivianas.

El presente texto está organizado de la siguiente manera:

¿Qué es un Estado Plurinacional?

Capítulo I: Modelo de Estado

Capítulo II: Ordenamiento Territorial y Autonomías

Capítulo III: Régimen de Tierra y Territorio Capítulo IV: Régimen Económico

Capítulo V: Régimen Social Capítulo VI: Derechos, Deberes y Garantías

Por las organizaciones:

Confederación Sindical Única de Trabajadores Campesinos de Bolivia CSUTCB

Confederación de Pueblos Indígenas de Bolivia - CIDOB

Confederación Sindical de Colonizadores de Bolivia - CSCB

Federación Nacional de Mujeres Campesinas de Bolivia "Bartolina Sisa" FNMCB-BS

Consejo Nacional de Ayllus y Markas del Qullasuyu - CONAMAQ

Coordinadora de Pueblos Étnicos de Santa Cruz - CPESC

Movimiento Sin Tierra de Bolivia - MST

Asamblea del Pueblo Guaraní - APG

Confederación de Pueblos Étnicos Moxeños de Beni - CPEMB

\section{¿Qué es un Estado Plurinacional?}

Las naciones y pueblos indígenas originarios y campesinos ${ }^{4}$ hoy tenemos el desafío de participar en la refundación de Bolivia, construyendo un nuevo país fundamentado en los pueblos como sujetos colectivos, hacia la construcción de un Estado Plurinacional que trascienda el modelo de Estado liberal y monocultural cimentado en el ciudadano individual. Bolivia, como los demás Estados de América Latina, ha construido un modelo liberal caracterizado por la imposición de la cultura occidental que ha marginado y debilitado nuestras culturas originarias y nuestros sistemas políticos y jurídicos. La división político administrativa ha impuesto fronteras que han roto las unidades territoriales tradicionales, resquebrajando la autonomía y control sobre la tierra y recur- sos 
naturales. Se ha impuesto un sistema jurídico uniforme, modelos de gobierno y administración de justicia ajenos, que favorecen los intereses del mercado y privan a los pueblos de sus medios de subsistencia, y por lo tanto deterioran nuestra calidad de vida. Pero a pesar de siglos de imposición hemos resistido y mantenido nuestras identidades, por eso en Bolivia hoy habitamos diversas naciones, pueblos y culturas con derecho a una convivencia solidaria y pacífica, por eso proponemos fundar un Estado Plurinacional Unitario. Entendemos que el Estado Plurinacional es un modelo de organización política para la descolonización de nuestras naciones y pueblos, reafirmando, recuperando y fortaleciendo nuestra autonomía territorial, para alcanzar la vida plena, para vivir bien, con una visión solidaria, y de esta manera ser los motores de la unidad y el bienestar social de todos los bolivianos, garantizando el ejercicio pleno de todos los derechos. Para la construcción y consolidación del Estado Plurinacional, son fundamentales los principios de pluralismo jurídico ${ }^{5}$ unidad, complementariedad, reciprocidad, equidad, solidaridad y el principio moral y ético de terminar con todo tipo de corrupción.

Nuestra decisión de construir el Estado Plurinacional basado en las autonomías indígenas, originarias y campesinas debe ser entendida como un camino hacia nuestra autodeterminación como naciones y pueblos, para definir nuestras políticas comunitarias, sistemas sociales, económicos, políticos y jurídicos, y en este marco reafirmar nuestras estructuras de gobierno, elección de autoridades y administración de justicia, con respeto a formas de vida diferenciadas en el uso del espacio y el territorio.

Jurídicamente nuestra propuesta se fundamenta en los derechos colectivos consagrados en Tratados Inter- nacionales de Derechos Humanos, como el Convenio 169 de la OIT $^{6}$. Es de especial importancia nuestro derecho a la tierra y los recursos naturales: buscamos poner fin al latifundio y a la concentración de la tierra en pocas manos, y al monopolio de los recursos naturales en beneficio de intereses privados.

La estructura del nuevo modelo de Estado Plurinacional implica que los poderes públicos tengan una representación directa de los pueblos y naciones indígenas originarias y campesinas, según usos y costumbres, y de la ciudadanía a través del voto universal. Asimismo, tendrá que determinarse la forma como se articularán los distintos niveles de la administración pública y las autonomías territoriales.

\section{CAPÍTULO I Modelo de Estado}

\section{Caracterización del país}

Bolivia es un país independiente, soberano, libre, participativo, social, comunitario y democrático?

\section{Caracterización del Estado}


El Estado boliviano es unitario, plurinacional, pluriétnico, plu- ricultural, intercultural y plurilingüe, descentralizado en auto- nomías territoriales indígenas originarias y campesinas, en autonomías interculturales urbanas y en autonomías regiona- les, con respeto a formas de vida diferenciadas en el uso del espacio y territorio.

\section{Principios del Estado}

\begin{tabular}{|c|c|c|}
\hline - Unidad & - Transparencia & $\begin{array}{l}\text { - Acción positiva para la } \\
\text { equidad }\end{array}$ \\
\hline - Equidad & - Redistribución & - Integridad territorial \\
\hline - Reciprocidad & - Independencia & - Vivir bien \\
\hline - Complementariedad & - Pluralismo juridico & $\begin{array}{l}\text { - Democracia participativa y } \\
\text { de consensos }\end{array}$ \\
\hline - Solidaridad & - Responsabilidad social & \\
\hline
\end{tabular}

\section{Valores del Estado}

Son valores del Estado Plurinacional: la libertad, la igualdad, el respeto a la vida y la dignidad humana, preeminencia de los derechos humanos y los derechos colectivos.

\section{Sistema de gobierno}

El sistema de gobierno boliviano es democrático: participativo y representativo. En cuanto al sistema de participación, las naciones y pueblos indígenas originarios y campesinos ejercen representación directa en los distintos niveles de gobierno, elegidos en base a sus usos y $\operatorname{costumbres}^{8} \mathrm{y}$ al principio de democracia comunitaria.

\section{Mecanismos de la Democracia}

La soberanía reside en el pueblo, cuya voluntad es la base de la autoridad, será 
ejercida directamente mediante los siguien- tes mecanismos de democracia representativa, participativa, comunitaria, deliberativa y directa.

\section{a. Mecanismos de Democracia Participativa}

Se plantean los siguientes mecanismos de democracia participativa y directa:

\begin{tabular}{l|l}
\hline - Asamblea Constituyente & - Veto popular \\
\hline - Referéndum & - Cabldos comunales - indigenas - populares \\
\hline - Plebiscito & - Asambleas comunales - indigenas - populares \\
\hline - Iniciativa Legislativa Ciudadana & - Otros mecanismos de democracia directa \\
\hline - Revocatoria de mandato & \\
\hline
\end{tabular}

\section{b. Mecanismos de Democracia Representativa}

Los mecanismos de la democracia representativa son los siguientes:

- Elección de representantes por voto universal y di- recto, bajo el principio de revocatoria del mandato.

- Elección de representantes por usos y costum- bres en los territorios de las naciones y pueblos indígenas originarios y campesinos para los distintos niveles de gobierno.

\section{Estructura y Poderes del Estado}

El Estado boliviano se estructura en tres niveles: central, intermedio y local. Los niveles intermedio y local son niveles autóno- mos con igual jerarquía en la Constitución Política del Estado. Los poderes del Estado son los siguientes: Poder Ejecutivo, Poder Legislativo, Poder Judicial y Poder Social Plurinacional.

\subsection{Caracterización del Poder Ejecutivo}

Coherente con la estructura del Estado, el Poder Ejecutivo se organiza en los niveles central, intermedio y local. En el nivel central, el sistema es presidencialista; es decir, conformado por el presidente y ministros. La elección de presidente contemplará la segunda vuelta entre los dos candidatos más votados en la primera vuelta, de no existir mayoría absoluta en esta. El mandato del presidente es de 5 años y es susceptible de ser revocado. Para la designación de la estructura del Poder Ejecutivo, las organizaciones sociales proponen, mediante ternas, nombres de personas idóneas al Presidente de la Repú- blica. A partir de estas ternas, el Presidente designa el 50\% de sus ministros y ministras de acuerdo a las propuestas presen- tadas, garantizando que la mitad sean mujeres. [...] 


\subsection{Caracterización del Poder Judicial}

El pluralismo jurídico es parte del ordenamiento jurídico del Estado, teniendo en cuenta los Derechos Humanos Funda- mentales, los derechos colectivos que serán definidos en la nueva Constitución y los convenios internacionales sobre las naciones y pueblos indígenas originarios y campesinos.

Los sistemas jurídicos y formas de administración de la justicia indígena originaria tienen la misma jerarquía que la justicia positiva, con base en la autonomía territorial indígena, para juzgar y sancionar delitos y contravenciones de acuerdo a usos y costumbres, respetando los derechos humanos y la no intromisión de la justicia positiva. No corresponde a la justicia positiva anular o modificar las decisiones de las autoridades de la justicia comunitaria de las naciones y pueblos indígenas originarios y campesinos. Los usos y costumbres tienen validez legal en todas las instancias judiciales. El nombramiento de sus autoridades se hace de acuerdo con las normas internas de cada nación y pueblo indígena originario y campesino.

Las máximas autoridades judiciales son elegidas mediante voto directo.

Las instancias judiciales, en los distintos niveles de la estructura del Estado, se conforman con la participación de representantes de las naciones y pueblos indígenas origi- narios y campesinos.

Los niveles de articulación y coordinación entre la justicia positiva y la justicia indígena serán definidos poste- riormente a través de una ley ${ }^{9}$.

\subsection{Caracterización del Poder Social Plurinacional}

El Poder Social Plurinacional tiene las siguientes características:

- Es independiente y autónomo respecto de los poderes del Estado.

- Vigila y controla a los poderes del Estado.

- Denuncia los actos irregulares del ejercicio de la función pública. Sus decisiones son inapelables y de cumplimiento inmediato por parte de los poderes del Estado.

- Está formado por representantes de la sociedad civil (naciones y pueblos indígenas originarios y campesinos, representantes de las organizaciones sociales y otros).

- En el nivel central, los representantes son elegidos por voto universal; en los niveles local e intermedio, se los elige por usos y costumbres.

\section{Del Estado y la Religión}


El Estado boliviano es laico; reconoce la libertad de culto y el ejercicio de las prácticas espirituales de las naciones y pueblos indígenas originarios $\mathrm{y}$ campesinos, siempre que no violen los derechos fundamentales.

\section{Del Estado y los Idiomas}

Son idiomas oficiales los idiomas indígenas de las naciones y pueblos indígenas originarios y el castellano. El Estado protegerá y fomentará el desarrollo de los idiomas indígenas en todas sus estructuras y niveles. Las personas que ocupen un cargo público deberán hablar la lengua indígena de la región.

$[\ldots]$

\section{CAPÍTULO II}

\section{Ordenamiento Territorial y Autonomías}

\section{Ordenamiento Territorial y Autonomías}

El régimen de ordenamiento territorial y las autonomías indígenas originarias y campesinas se proponen en el marco de la búsqueda de la unidad plurinacional.

Se constitucionalizan las autonomías indígenas originarias y campesinas, basadas en varios principios retomados de los distintos pueblos, como un paso hacia su autodeterminación.

Lo plurinacional se expresa en la existencia de naciones y pueblos indígenas originarios y campesinos.

\section{División político administrativa del país}

Se reordena territorialmente el país sobre la base de la constitución de autonomías territoriales indígenas originarias y campesinas. Además, se constituyen autonomías interculturales urbanas.

A partir de estas autonomías se constituye el su- jeto autonómico del nivel intermedio.

Las naciones y pueblos indígenas originarios y campesinos se autoconstituyen en autonomías territoriales a partir de sus propios criterios lingüísticos, históricos, culturales, de continuidad geográfica, organizativos.

Se constituyen, por tanto, tres niveles de organi- zación político administrativa del Estado.

Local: autonomías territoriales indígenas origina- rias y campesinas y autonomías interculturales urbanas.

Intermedio: Regiones. 
Plurinacional: Estado Unitario Plurinacional.

\section{De las Autonomías en general}

\section{Finalidad}

Las autonomías apuntan a romper la verticalidad del actual Estado, su estructura de poder, permitiendo la construcción de un nuevo Estado desde "abajo", desde las bases. Aspectos generales Los principios y valores rectores de las autonomías son:

- Unidad

- Pluralidad

- Equidad

- Reciprocidad ${ }^{10}$

- Solidaridad

En la Constitución Política del Estado se establecerán los contenidos y principios de las normas rectoras de las autonomías. En el marco de sus competencias, cada nivel autonómico tiene la facultad de legislar normas internas, previa consulta ciudadana.

\section{Autonomías indígenas \\ Conceptualización}

"La autonomía indígena originaria y campesina es la condición y el principio de libertad de nuestros pueblos y naciones como categoría fundamental de descolonización y autodeterminación; está basada en principios fundamentales y generadores que son los motores de la unidad y articulación social, económica y política al interior de nuestros pueblos y naciones y con el conjunto de la sociedad. Se enmarca en la búsqueda incesante de la construcción de la vida plena, bajo formas propias de representación, administración y propiedad de nuestros territorios"11.

Finalidad de las autonomías territoriales indigenas

Garantizar la unidad pluricultural del país y la autodetermi- nación y autogobierno de los pueblos y naciones indígenas originarios y campesinos para definir sus sistemas jurídicos, económicos, sociales, culturales y estructuras de gobierno y elección de autoridades.

Principios y valores de las autonomías territoriales indigenas 
- Identidad cultural

- Solidaridad

- Democracia participativa

- Justicia social

- Gestión comunitaria

- Unidad

- Libertad

- Respeto y consideración mutua

- Reciprocidad

- Generosidad

- Transparencia

- Pluralismo jurídico

- Equidad

Principios de las autonomías territoriales indígenas para la gestión de los recursos naturales

- Unidad

- Reciprocidad

- Solidaridad

- Equidad

- Igualdad

- Complementariedad

- Sostenibilidad económica, social y ambiental

- Distribución solidaria, justa y equitativa de los beneficios

- Protección, preservación y conservación de los Recursos Naturales

- Educación ambiental 
- Control social con base de sostenibilidad econó- mica, social y ambiental

\section{Elementos que caracterizan la autonomía territorial indígena}

\section{Territorio}

Población culturalmente diferenciada: idioma, cultura, historia

- Gobierno y administración indígena originario y campesino basado en sus usos y costumbres, con poder de decisión

- Normas propias de acuerdo con la cultura, usos, costumbres y saberes

- Administración de justicia basada en usos y costumbres

- Control y gestión comunitaria sobre el territorio, la tierra y recursos naturales

- Patrimonio, presupuesto y recursos propios

Criterios para organizar territorialmente las autonomías indígenas

Las autonomías indígenas originarias y campesinas se estructuran en base a los territorios habitados, ancestrales o por ecosistemas, con base cultural en los pueblos indígenas originarios y campesinos ${ }^{12}$.

\section{Elección de autoridades}

Corresponde definir a cada pueblo indígena originario y campesino, según sus usos y costumbres, la forma de elección de sus autoridades.

\section{Competencias}

Las autonomías territoriales indígenas originarias y campesinas ejercen las siguientes competencias en sus territorios:

- Administración, uso y manejo sustentable de Recursos Naturales renovables de acuerdo a usos y costumbres.

- Participación en la toma de decisiones sobre todo el proceso de exploración, explotación, in- dustrialización y comercialización de los recursos no renovables del país que se encuentren en sus territorios.

- Consulta y/o veto frente a la exploración y explotación de recursos naturales no renovables, a través de las organizaciones genuinas, legítimas y representativas de las naciones y pueblos indígenas originarios y campesinos, según los procedimientos correspondientes a cada cultura. La consulta tendrá las siguientes características: previa, obligatoria, de buena fe, informada y vinculante. 
- Administración, control y preservación de la tierra. Co-administración y cogestión de los recursos no renovables con el Estado Unitario Plurinacional.

- Participación en beneficios y control del proceso de exploración y explotación de los recursos na- turales no renovables. Asimismo, tendrán derecho a la prevención, mitigación, compensación, reparación e indemnización por los daños socio- ambientales y culturales ocasionados.

- Definir sus sistemas jurídicos, elegir autoridades y estructuras de gobierno para la gestión auto- nómica. Las autoridades de las autonomías indígenas originarias y campesinas tienen recono- cimiento de orden constitucional, corresponden a cada pueblo según sus usos y costumbres sin que se requiera ningún trámite adicional ante otra entidad de la República.

- Administración de los bienes y servicios territo- riales, tales como: la tierra, los recursos naturales renovables, educación, salud y otros.

- Participación directa de los pueblos indígenas en los procesos de gestión pública, generando espacios institucionales que permitan su plena incorporación en los niveles de administración por fuera de su territorio.

- Planificación, prestación y administración del servicio de salud indígena en cogestión con el Estado Plurinacional, organizado a nivel comunitario, de acuerdo a las visiones y prácticas culturales pro- pias en articulación con otros sistemas de salud.

- Definición de políticas educativas en lo institu- cional y curricular, además prestación y adminis- tración del servicio de educación intercultural en cogestión con el Estado Plurinacional. Se garantiza la formación de recursos humanos comunitarios para la gestión y el control del territorio autónomo.

- Promoción y revalorización de las artes y las culturas indígenas.

- Definición y aplicación de normas para una seguridad jurídica en el trabajo.

- Creación y administración de instituciones y empresas públicas descentralizadas y desconcentradas.

- Administrar justicia de acuerdo con sus sistemas jurídicos. La Ley compatibilizará estas funciones con las atribuciones de los poderes del Estado.

- Planificación y ejecución de su desarrollo eco- nómico, cultural y social acorde a la identidad y visiones propias y desde una perspectiva inter- cultural.

- Registro, resguardo y regulación de la propiedad intelectual colectiva sobre sus recursos naturales, genéticos y culturales.

- Coordinación y control de las instituciones y organizaciones externas que 
desarrollan actividades en el territorio.

\section{CAPÍTULO III}

\section{Régimen de Tierra y Territorio ${ }^{13}$}

\section{Territorio: Recursos Naturales, Biodiversidad y Medio Ambiente}

- Los planes de vida integrales y equilibrados (desarrollo sostenible) incluyen el conjunto de políticas destinadas a la conservación de los recursos naturales renovables y no renovables, determinando su utilización racional de manera que permita satisfacer las necesidades de la población actual, sin poner en riesgo a las generaciones futuras.

- Toda extracción de los recursos naturales renovables y no renovables al interior del territorio plurinacional está sujeta a procesos de consulta previa y obligatoria a las organizaciones sociales del lugar, garantizando procesos de prevención y control socioambiental y promoviendo la conser- vación de los ecosistemas.

- El dominio originario de los recursos no renovables es de las naciones y pueblos indígenas originarios y campesinos. La propiedad de los recursos no renovables es compartida entre las naciones y pueblos indígenas originarios y cam- pesinos y el Estado Unitario Plurinacional ${ }^{14}$.

- Las naciones y pueblos indígenas originarios y campesinos participan en la toma de decisiones sobre todo el proceso de exploración, explotación, industrialización y comercialización de los recursos no renovables; esto implica derecho a la consulta vinculante a los pueblos y naciones que habitan en los territorios donde se encuen- tran estos recursos.

- Las naciones y pueblos indígenas originarios y campesinos co-administran, cogestionan los recursos no renovables con el Estado Unitario Plurinacional. Asimismo, tienen participación equitativa en los beneficios provenientes del aprovechamiento de los recursos que existen en sus territorios y tienen derecho a la prevención, mitigación, compensación, reparación e indemnización por los daños socioambientales y culturales ocasionados por la exploración y explotación de los recursos no renovables.

- Antes de realizar cualquier exploración y explotación comercial de recursos naturales deberán realizarse estudios participativos de impacto socioeconómico, ambiental y comunitario, que serán la base para la elaboración de los correspondientes planes de manejo, en caso de que proceda la explotación o aprove- chamiento.

- Los beneficios provenientes del aprovechamiento de los recursos no renovables que existen en los territorios indígenas originarios se sujetan al principio de redistribución equitativa con justicia social para todo el país. 
- En los territorios indígenas los recursos naturales renovables son de dominio y propiedad de las naciones y pueblos indígenas originarios y campesinos, siendo la decisión, el uso y aprovechamiento de los mismos exclusivos de estos.

- Las naciones y pueblos indígenas originarios y campesinos, en sus territorios, tienen el dominio y la propiedad de la naturaleza, los ecosistemas, la biodiversidad, el recurso genético, así como los saberes y conocimientos. Es deber del Estado protegerlos y fomentarlos.

- El agua, por ser un bien social, de derecho huma- no y de salud, no debe ser concesionada, privatizada, ni exportada. El Estado, antes de desarrollar cualquier actividad de uso y aprovechamiento de este recurso, deberá consultar y consensuar con las comunidades indígenas originarias, campesinas y organizaciones sociales del lugar. [...]

\section{Tierra ${ }^{15}$}

- Es misión del Estado Plurinacional y de las auto nomías territoriales indígenas originarias y cam- pesinas promover la distribución equitativa de tierras, previendo los derechos y necesidades actuales y futuras de las naciones y pueblos indígenas originarios y campesinos y el bienestar de toda la población.

- La tierra y el territorio son dominio de las naciones y pueblos indígenas originarios y campesinos en el marco de la soberanía del Estado Plurinacional. El Estado Plurinacional y las naciones y pueblos tienen responsabilidad compartida en la preser- vación y conservación del medio ambiente.

- El Estado Plurinacional garantiza, protege y fomenta de manera preferente las diferentes for- mas de dominio y propiedad colectiva-comunitaria de la tierra.

- Las tierras, en los territorios de las naciones y pueblos indígenas originarios y campesinos, son de dominio colectivo-comunitario; son inembargables, intransferibles, imprescriptibles, inaliena- bles, irreversibles, indivisibles y están exentas del pago de impuestos.

- En los territorios de las naciones y pueblos indígenas originarios y campesinos la tierra es administrada según las normas, usos y costumbres de los pueblos y naciones que los habitan, con el apoyo del Estado Plurinacional.

- El Estado Plurinacional dotará las tierras fiscales de forma exclusiva en favor de las comunidades campesinas y originarias indígenas sin tierra o con tierra insuficiente. Las tierras dotadas se sujetarán a los preceptos y normas del dominio colectivo-comunitario. 


\section{Bibliografia}

ABBAGNANO, Nicola. Dicionário de Filosofia. $21^{\text {a }}$ Edição. Tradução: Alfredo Bosi. São Paulo, SP: Martins Fontes, 1998.

ALBÓ, Xavier. Pueblos índios en la política. Cuadernos de investigación/CIPCA, 55. La Paz: Plural Ed., 2002.

ALBÓ, Xavier e RUIZ, Carmen Beatriz. Diálogo-Asamblea Constituyente: un balance a varias voces. Tinkazos, DIC 2010, vol. 13.

http://www.scielo.org.bo/scielo.php?pid=S1990-

$\underline{74512010000300005 \& \text { script }=\text { sci arttext }}$

ALTAMIRANO, Diego Francisco. Historias de la Misión de los Mojos. La Paz, IBC, 1979.

ANDERSON, Benedict R. O G. Comunidades Imaginadas: reflexões sobre a origem e a difusnao do nacionalismo. São Paulo: Companhia das Letras, 2011.

ANDRADE, Edgar Ramos. Los indígenas del oriente y la Asamblea Constituyente. 5 de abril de 2004. Disponível em: http://www.bolpress.com/art.php?Cod=2002078713, acessado em 05 de março de 2015.

ANDRADE, Wildes Sousa. A construção da nação guarani pela Asamblea del Pueblo Guaraní a partir da comemoração do massacre de Kuruyuki. Dissertação de mestrado, defendida 08 de outubro de 2014, CEPPAC- UnB.

ALAI, América Latina en Movimiento. Segundo Encuentro Social Alternativo Declaración de Camiri. 12 de setembro de 2005. Disponível em: http://alainet.org/active/9194\&lang=pt, acessado em janeiro de 2011.

AMORIM, Ana Maria Martins. Os direitos indígenas no Estado Plurinacional da Bolívia: Um estudo da discursividade legislative sobre os direitos indígenas em tempos de pós-colonialidade. Dissertação de mestrado, defendida em 16 de junho de 2014, CEPPAC- UnB.

ARGUEDAS, Alcides; LORENTE MEDIA, Antonio. Raza de bronce: wuata wuara. Nanterre: Assoc Arch Lit Latino-Am, Caraibes \&, 1988.

ARGUEDAS, Alcides. Pueblo enfermo. La Paz: Gisbert, 1979.

ASBUN, Jorge A. R. El processo constituyente actual en Bolivia. La constante tensión entre libertad y autoritarismo. Instituto de Investigacion Juridica, UNAM. 2010. Disponível em: http://biblio.juridicas.unam.mx/libros/6/2728/4.pdf, acessado em janeiro de 2011.

BALZA, Roberto B. A. Tierra, território y territorialidade indígena: un estúdio 
antropológico sobre la evolución en las formas de ocupación del espacio del Pueblo indígena chiquitano de la ex-reducción jessuita de San José. Santa Cruz de la Sierra, Bolivia Apoyo para el Campesino-Indígena del Oriente Boliviano, 2001.

CRESPO, Carlos. Estado y autonomia en Bolívia, una interpretación anarquista. 19 de abril de 2011. Disponível em: http://www.bolpress.com/art.php?Cod=2011041902, acessado em 5 de março de 2015.

BAUMAN, Gerd \& GINGRICH, Andre. Grammars of identity/alterity : a structural approach. New York - Oxford: Berghahn Book, 2004.

BOLIVAR, Simón. Doctrina del Libertador. Caracas, Fundación Biblioteca Ayacucho, 1985.

BRACHO, Jorge. Narrativa e identidad: El mestizaje y su representación historiográfica. Latinoamérica, México, n. 48, janeiro de 2009. Disponível em: $<$ http://www.scielo.org.mx/scielo.php?script=sci_arttext\&pid=S1665-

$85742009000100004 \& \operatorname{lng}=\mathrm{es} \& n r m=i s o>$. Acessado em 06 março de 2015.

BRAUDEL, Fernand. Écrist pour l'Histoire. Paris: Flamarion, 1969.

CANÇADO TRINDADE, A. A. . A proteção internacional dos Direitos Humanos. Rio de Janeiro: SBERJ, 1988.

CALLA, Ortega, Ricardo, Identificación étnica y procesos políticos en Bolivia (19731991), en VVAA, Democracia, etnicidad y violencia política en los países andinos, Lima, IFEA-IEP, 1993

CAMARGO, Alfredo José Cavalcanti Jordão de. Bolívia - A criação de um novo país a ascenção do poder político autóctone das civilizações pré-colombianas a Evo Morales. Brasília: Fundação Alexandre de Gusmão, 2006. Disponível em: http://funag.gov.br/loja/download/332-BolIvia___A_Criacao_de_um_Novo_PaIs.pdf acesso em 5 de março de 2015.

CAMARGO, Tamara Lopes Martins. Sociogênese do Estado plurinacional na Bolívia contemporânea: Etnografando o Viceministerio de Descolonización. Dissertação de mestrado, defendida 29 de julho de 2014, CEPPAC- UnB.

CÉSPEDES, Augusto. Sangre de mestizos - relatos de la guerra del Chaco. Santiago, Chile, Nascimiento. 1936.

CHÁVEZ, Marxa Nadia. Autonomías indígenas" y "Estado Plurinacional" - Proyectos políticos de los movimientos indígenas y campesinos en Bolivia. Em Debates “Autonomias Indígenas" y "Estado Plurinacional". Ano IX, No 24, Outubro de 2008. CLACSO. Disponível em:

http://bibliotecavirtual.clacso.org.ar/ar/libros/osal/osal24/03chavez.pdf, acessado em 8 de março de 2015.

CHIVI, Idón Moisés C. V. Os caminhos da descolonização na América Latina: os Povos 
Indígenas e o igualitarismo jurisdicional na Bolivia. In: VERDUM, Ricardo (Org.) "Povos Indígenas. Constituições e reformas políticas na America latina”. Brasília, INESC, 2009.

CHUJI, Mónica C. Gualinga. Diez conceptos básicos sobre plurinacionalidad e interculturalidad. ALAI - América Latina em movimento, 2008. Disponível em: http://alainet.org/active/23366\&lang=es, acessado em 5 de março de 2015.

CLASTRES, Pierre. A sociedade contra o Estado: pesquisas de antropologia política. São Paulo: Cosac \& Naify, 2003.

COMBÈS, Isabelle. Las batallas de Kuruyuki. Variaciones sobre una derrota chiriguana. Bulletin de L'instittut Français d'Études Andines/2005,

Disponível em: http://www.ifeanet.org/publicaciones/boletines/34\%282\%29/221.pdf acessado em 05 de março de 2015.

Indios y blancos? Hacer (etno) historia en las tierras bajas de Bolivia. Boletín Americanista. Universidad de Barcelona, Facultad de Geografia e Historia. Ano LX.1, Barcelona, 2010. Disponível em: http://www.publicacions.ub.edu/refs/indices/07355.pdf, acessado em março de 2015.

CORDOBA, L. e VILLAR, D. Etnonimia y relaciones interétnicas entre los panos meridionales. Revista Andina, no 49, segundo semestre de 2009.

DELEUZE, Gilles, e Félix GUATTARI. O que é a Filosofia? Tradução: Bento Prado Jr e Alberto Alonso Munoz. São Paulo, SP: Editora !34, 1992.

DERPIC, Carlos D. S. Consideraciones acerca de la reforma constitucional de 1994: el caso indígena. Revista Ciencia y Cultura n.10 La Paz, março de 2002.

ELLERBECK, Alexandra, "Unidad Fraccionada: Las Tensiones de la Coalición Indígena Originario Campesino y de la Base Popular del Movimiento al Socialismo". Independent Study Project (ISP) Collection. Paper 1302, 2012.

http://digitalcollections.sit.edu/isp_collection/1302

FAUSTO, Carlos. Os índios antes do Brasil. Rio de Janeiro, Jorge Zahar, 2000.

FERNÁNDEZ, Hugo. Suma Qamaña, Vivir bien, El Ethos de la Nueva Constitución Boliviana. Universidade de Alicante. Revista Obets, 4, 2009

http://publicaciones.ua.es/filespubli/pdf/19891385RD41295095.pdf

GAMBOA, Franco. Dilemas e conflictos en la Asamblea Constituyente - História Política de la Asambleia Constitucional. Editora Presença, La Paz, 2009.

http://www.bivica.org/upload/dilemas-constitucion.pdf

GARCÉS, Fernando G. V. Os esforços de construção descolonizada de um Estado Plurinacional na Bolívia e os riscos de vestir o mesmo cavalheiro com um novo paletó. In: VERDUM, Ricardo (Org.) "Povos Indígenas. Constituições e reformas políticas na America latina”. Brasília, INESC, 2009. 
GÁRCIA, Alvaro Linera. Sociología de los movimientos sociales en Bolivia. La Paz, Diakonia, Oxfam y Plural, 2004.

. La Crisis de Estado y las sublevaciones indígena plebeyas. In: Álvaro García Linera, Luis Tapia y Raúl Prada, Memorias de octubre, La Paz, Comuna y Muela del Diablo, 2004.

Autonomías regionales indígenas y estado multicultural. In: aa. vv., La descentralización que se viene, La Paz, Instituto Latinoamericano de Investigaciones Sociales (ildis) y Plural, 2004.

Movimientos sociales y democratización política. In: Robinson Salazar, Eduardo Sandoval y Dorangélica de la Rocha (eds.). Democracias en riesgo en América Latina, México, Comisión Estatal para el Acceso a la Información Pública del Estado de Sinaloa e Insumisos Latinoamericanos, 2003.

Democracia, conflicto y movimientos sociales. Acerca de la democracia substantiva. In: Democracia y conflicto social en Bolivia, La Paz, Konrad Adenauer Stiftung y The State University of New York, 2004.

Etnias, naciones y Estado. Una lectura pluralista de las democracias y las ciudadanías en Bolivia. In: aa. vv., Visiones y contextos para un nuevo desarrollo rural, La Paz, Agencia Suiza para el Desarrollo y la Cooperación (cosude), Asociación de Instituciones de Promoción y Educación (aipe) y Grupo de Desarrollo Rural (dru), 2002.

. La estructura de los movimientos sociales en Bolivia. In: Observatorio Social de América Latina, № 5, 2001.

Espacio social y estructuras simbólicas. Clase, dominación simbólica y etnicidad en la obra de Pierre Bourdieu. In: Hugo José Suárez et al., Bourdieu leído desde el sur, La Paz, Embaxada da França, Plural y Alianza Francesa, 2000 .

- Narrativa colonial y narrativa comunal. Un acercamiento a la rebelión indígena como reinvención de la política. In: Memoria de la XI Reunión Anual de Etnología, La Paz, Museo Nacional de Etnografía y Folklore (musef), 1998.

Roja, 1989.

. Critica de la nación y la nación critica. La Paz, Ofensiva

GONZÁLEZ, Miguel, BURGUETE, Araceli B. Cal y Mayor e ORTIZ-T, Pablo Coord. La autonomia a debate: Autogobierno indígena y Estado plurinacional en América Latina. Série Foro, Flacso, Quito, 2010.

http://www.servindi.org/pdf/Autonomia_a_debate.pdf

HOBSBAWM, E. J. Nações e nacionalismo desde 1780: Programa, mito e realidade. 4. Ed. Rio de janeiro: Paz e Terra, 2004.

HONNETH, Axel. Luta por reconhecimento: a gramática moral dos conflitos sociais. 
São Paulo: Ed. 34, 2003

KOHL, Benjamin H. \& FARTHING, Linda C. Impasse in Bolivia : neoliberal hegemony and popular resistance. London, Zed Books 2006.

https://books.google.com.br/books?id=tEKgN9YCNWsC\&pg=PA159\&lpg=PA159\&dq $=$ CONAMAQ $+e+C S U T C B+$ historia\&source $=$ bl\&ots $=\_a 4 e H c 2-$

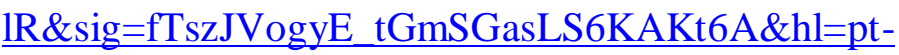

$\underline{B R \& s a=X \& e i=k o \_g V N H 3 F Y T n s A T a 6 Y G o C A \& v e d=0 C D c Q 6 A E w A w \# v=o n e p a g e \& q ~}$ $=$ CONAMAQ $\% 20 \mathrm{e} \% 20 \mathrm{CSUTCB} \% 20$ historia $\& \mathrm{f}=$ false

LATOUCHE, Serge. A ocidentalização do mundo: ensaio sobre a significação, o alcance e os limites da uniformização planetária. Petrópolis, RJ: Vozes, 1994.

LÓPES, Luis Enrique. Plurinacionalidad y ciudadanía en Bolivia: revisión de un largo recorrido y situación actual. Revista interamenticana de Educación para la Democracia. Vol. 2, no 2, 2009.

Disponível em: www.ried.ijed.org, acessado em 06 de março de 2015

LEHM, Zulema. Milenarismo y movimientos sociales en la amazonía boliviana. La búsqueda de la Loma Santa y la marcha indígena para el territorio y la dignidade. Santa Cruz: CIDDEBENI-A.P.C.O.B. Oxfam America, 1999.

MANN, Charles C. 1491: novas revelações sobre as Américas antes de Colombo. Rio de Janeiro, Objetiva, 2007.

MARIÁTEGUI, José Carlos. 7 ensaios de interpretação da realidade peruana. São Paulo: Alfa-Omega, 1975.

Disponível em: https://www.marxists.org/espanol/mariateg/1928/7ensayos/03.htm acessado em março de 2015.

MARIÁTEGUI, José Carlos; QUIJANO, Aníbal. Ensayos escogidos - Volume 10 de Biblioteca peruana de cultra básica: Primera serie de autores peruanos. Lima: Patronato del libro peruano, 1956.

MESA, Carlos D. M. Gisbert; MESA, José de e GISBERT, Tereza. Historia de Bolivia. La Paz Ed. Gisbert y Cia, 1998.

MESA, Carlos D. M. Gisbert. Un gobierno de ciudadanos. Plural y Fundación Comunidad, 2008.

MORAES, Renata Albuquerque de. Desenvolvimento e vivir bien: o caso do Território Indígena e Parque Nacional Isiboro Sécure (Bolívia). Dissertação (mestrado) Universidade de Brasília, Instituto de Ciências Sociais, Centro de Pesquisa e PósGraduação sobre as Américas, Programa de Pós-Graduação em Estudos Comparados sobre as Américas, 2014. 
METHOL-FERRÉ, Alberto. La conquista espiritual. Enciclopedia Uruguaya, nº5. Montevideo. Arca, 1968.

MONTANO, Claudia Victoria M. S. 2006. Movilizaciones Indígenas - Su articulación, Adecuación Institucional. Programa Incidencia Política - CEJIS, dezembro de 2006 [anexo]. In: VALENCIA, Maria del Pilar G. e ÉGIDO, Ivan Z. Los pueblos indígenas de tierras bajas en el processo constituyente. Santa Cruz - CEJIS, 2010.

NEGRI, Antonio \& DE MARCO, Clara. El poder constituyente: ensayos sobre las alternativas de la modernidad. Madrid: Libertarias-Prodhufi, 1994.

NOSTAS, Mercedes N. A. TEJADA, Alicia T. S. Los pueblos indígenas y su relación con el nuevo Estado. 5 de julho de 2010. ALAI, América Latina en Movimiento. Disponível em: http://alainet.org/active/39312\&lang=es, acessado em 8 de março de 2015.

OSAL. Propuesta de las Organizaciones Indígenas, Originarias, Campesinas y de Colonizadores hacia la Asamblea Constituyente. (Buenos Aires: CLACSO) Año VIII, $\mathrm{N}^{\mathrm{o}} 22$, septiembre. 2007.

PABÓN, Leonardo García. De tinta y sangre de mestizos: Augusto Céspedes y el sujeto nacional moderno. Em La Patria intima: alegorias nacionalas en la literatura y el cine de Bolivia. La Paz. Plural. 1998.

https://books.google.com.br/books?id=czpmvDjkVGQC\&pg=PA169\&lpg=PA169\&dq= De+tinta $+\mathrm{y}+$ Sangre + de + mestizos: + Augusto $+\mathrm{C} \% \mathrm{C} 3 \%$ A 9 spedes $+\mathrm{y}+\mathrm{el}+$ sujeto + nacional + moderno\&source $=$ bl\&ots $=$ Ezq0gB7vXR\&sig $=0$ hYkW3ea2Izj4Fv66gkXGfjVnTs\&hl

$=$ pt-

BR\&sa $=$ X\&ei $=y 5$ LfVMuHCdfGsQTDmILQBQ\&ved $=0$ CCcQ6AEwAQ\#v=onepage \& q $=$ De $\% 20$ tinta $\% 20 \mathrm{y} \% 20$ Sangre $\% 20 \mathrm{de} \% 20$ mestizos $\% 3 \mathrm{~A} \% 20$ Augusto $\% 20 \mathrm{C} \% \mathrm{C} 3 \% \mathrm{~A} 9 \mathrm{~s}$ pedes $\% 20 \mathrm{y} \% 20 \mathrm{el} \% 20$ sujeto $\% 20$ nacional $\% 20$ moderno\&f $=$ false

PALTI, Elías. La nación como problema: Los historiadores y la "cuestión nacional”. México: Fondo de Cultura Economica, 2006.

PAZ, Sarela. La Bolívia de Evo - Diez años en el país de las mamitas. Publicação: Editorial Sudestada. 2014. Entrevista concedida à Tomás Astelarra.

PRADA, Raul. Las líneas de fuga de las marchas indígenas. De 25 de maio de 2012. Disponível em http://horizontesnomadas.blogspot.com.br/2012/05/las-lineas-de-fugade-las-marchas.html, acessado em março de 2015.

PINHO, José Antonio Gomes e SACRAMENTO, Ana Rita Silva. Accountability: já podemos traduzi-la para o português? RAP — Rio de Janeiro 43(6):1343-1368, nov./dez. 2009.

http://www.scielo.br/pdf/rap/v43n6/06.pdf

PLEVICH, Mary. Alcides Arguedas: Contemporary bolivian writer. Ann Arbor, 1957. 
PROEIB Andes. História de los Movimentos indígenas, 2008. Disponível em: http://programa.proeibandes.org/lideres/5ta/Modulos/Modulo01.pdf, acessado em 8 de março de 2015.

PRECIADO, Jaime C. La(s) autonomía(s) en América Latina. Una expresión socioespacial del estado novísimo y sus efectos en el proceso de integracion regional. (Axe IX, Symposium 37). Independencias - Dependencias - Interdependencias VI Congreso CEISAL, Toulouse, France. 2010.

https://halshs.archives-ouvertes.fr/halshs-00502206/document

QUEREJAZU, Roberto Q. Calvo. Historia de la Guerra del Chaco. La Paz, Bolívia: Livraria Editorial Juventud, 1990.

QUIROGA, Jaime e FLORES, Petronilo. La lucha de los movimientos indígena originario campesinos por sus derechos como aporte fundamental en la construcción del actual proceso histórico boliviano.

Disponível em:

http://www.uasb.edu.ec/UserFiles/369/File/PDF/Actividadespadh/invusocias/quirogaflo res.pdf, acessado em 8 de março de 2015.

RAMÍREZ, Silvina. Sete problemas do novo constitucionalismo indigenista. In: VERDUM, Ricardo (Org.) "Povos Indígenas. Constituições e reformas políticas na America latina”. Brasília, INESC, 2009.

REYES ABADIE, Washington - VAZQUEZ ROMERO, Alfredo. Crónica General del Uruguay. Tomos I, II, III. Ediciones de la Banda Oriental, Montevideo, 1978 - 1984.

RIBEIRO, Darcy. As Américas e a civilizaçãoo: processo de formação e causas do desenvolvimento desigual dos povos americanos. Rio de Janeiro: Civilização Brasileira, 1970.

RIVERA, Silva R. Cusicanqui. Oprimidos pero no Vencidos : Luchas del Campesinado Aymara y Qhecwa 1900-1980. Ediciones Yachaywasi, 2003, La Paz-Bolívia.

RIVERA, Silvia R. Cusicanqui. Pueblos originarios y estado. Vol. 2 de Gestión pública intercultural, Gestión pública intercultural. Azul Editores, 2008.

. Oprimidos pero no vencidos. Luchas del campesinado aymara y qhechwa de Bolivia, 1900-1980. La Paz, THOA, [1984] 2006.

ROCHA, José Antonio R. T. \& BAZOALTO, Carla María B. O. \& CUÉLlAR, Luis Fernando C. C. Autonomías indígenas, construcción de nación y fortalecimiento del Estado : estudios de caso en las regiones Norte de Potosí, guaraní del Isoso y kallawaya. La Paz, Bolivia : Programa de Investigación Estratégica en Bolivia; Cochabamba, Bolivia : Centro de Culturas Originarias Kawsay, 2008.

ROCHA, Mauricio Santoro. A outra volta do bumerangue: Estado, movimentos sociais e recursos naturais na Bolívia (1952-2006). In: Seminário América do Sul: América do Sul. Brasília: Fundação Alexandre de Gusmão, 2008. 
RODRIGUÉZ, Edwin Cruz. La acción colectiva en los movimientos indígenas de Bolivia y Ecuador, una perspectiva comparada. Instituto de Estudios Latinoamericanos - Universidad de Alcalá. IELAT, 2012.

ROMERO, Carlos R. Bonifaz. El processo constituyente boliviano: El hito de la cuarta marcha de tierras bajas. Santa Cruz de la Sierra: CEJIS, 2006.

SANTOS, Boaventura de Souza. (Orgs.). (2005). Democratizar a democracia: os caminhos da democracia participativa. Rio de Janeiro: Editora Civilização Brasileira.

SANTOS, Boaventura de Souza. La reinvención del Estado y el Estado Plurinacional. Alianza Interinstitucional CENDA - CEJIS - CEDIB. Santa Cruz de la Sierra, Bolívia. 2007.

Refundación del Estado en América Latina: perspectivas desde una epistemologia del Sur. La Paz, Bolivia: Universidad Mayor de San Simon, Centro de Estudios Superiores Universitarios: Plural editores, 2010.

SEGATO, Rita Laura. La nación y sus otros: raza, etnicidad y diversidade religiosa en tempos de políticas de la identidad. Buenos Aires: Prometeo Libros Editorial, 2007

PAZ, Sarela. La Loma Santa una utopía cercada: Territorio, cultura y Estado en la Amazonía boliviana. Tinkazos [online]. Vol.2, 2012.

SCHAVELZON, Salvador. El nacimiento del Estado Plurinacional de Bolívia Etnografia de una Asamblea Constituyente. CLACSO, Plural Editores, CEJIS, IWGIA. La Paz, janeiro de 2013.

http://biblioteca.clacso.edu.ar/clacso/coediciones/20130214112018/ElnacimientodelEsta doPlurinacional.pdf

. El Pacto de Unidad como encuentro cosmopolítico. Revista Boliviana de Investigación, v. 10, p. 235-261, 2013. Disponível em: http://www.academia.edu/7802919/El Pacto de Unidad como_Encuentro Cosmopol \%C3\%ADtico_Revista_de_Estudios_Bolivianos___2013, acessado em 05 de março de 2015.

SILES, Jorge Salinas. Historia de la independência de Bolivia. La Paz, Bolivia : Plural Editores, 2009.

http://books.google.es/books?id=KJ9peO3tdhYC\&lpg=PA299\&dq=Independencia\%20 del\%20Peru\&pg=PA298\#v=onepage\&q\&f=false

STAVENHAGEN, Rodolfo. Informe del Relator Especial sobre la situación de los Derechos Humanos y las libertades fundamentales de los Indígenas. Misión a Bolivia. Consejo de Derechos Humanos de las Naciones Unidas. Janeiro, 2009.

http://observatoriopoliticasocial.org/sitioAnterior/index.php?option=com_content\&view $=$ article \&id=777\&Itemid=221\#sthash.Ot9XqlsB.dpuf

STERN, Steve J. Resistance, rebellion, and consciousness in the Andean peasant world, 18th to 20th centuries. Madison, Wis: University of Wisconsin Press, 1987. 
VACAFLOR, Almut Schilling. Identidades indígenas y demandas político-jurídicas de la CSUTCB y el CONAMAQ en la Constituyente boliviana. Revista Bolivianas, Seção II. Investigações.

file://C:ISciELO\serial|rbcstlv11n23-24lpdflv11n23-24a10.htm

http://www.revistasbolivianas.org.bo/pdf/rbcst/v11n23-24/v11n23-24a10.pdf

TAMAYO, Franz. La creación de la pedagogía nacional. Biblioteca del Sesquicentenario, Volumen II, La Paz, Bolivia, [1919] 1975.

TAPIA, Luis T. Mealla. La velocidade del pluralismo: Ensayo sobre tempo y democracia. Colección Comuna. CIDES-UMSA. Bolívia: Muela del Diablo Editores, 2002.

TAPIA, Luis T. Mealla. La Condición Multisocietal: Multiculturalidad, Pluralismo, Modernidad. Colección Comuna. CIDES-UMSA. Bolívia: Muela del Diablo Editores, 2002.

TAPIA, Luis. El triple descentramiento: Igualdade y cogobierno en Bolivia. Em "Reinventando la nación en Bolivia - Movimientos sociales, Estado y poscolonialidad". Eds. Karin Monasterios; Pablo Stefanoni; Hervé do Alto. La Paz, Bolivia: CLACSO: Plural, 2007.

VALENCIA, Maria del Pilar G. e ÉGIDO, Ivan Z. Los pueblos indígenas de tierras bajas en el processo constituyente. Santa Cruz - CEJIS, 2010.

VERÓN, Luis. La Guerra del Chaco: un dramático episodio de la historia americana. Asunción: ABC Color, Editorial Azetea, 2003.

VIEIRA, Tiago Renato Tobias. A revolução boliviana de 1952: entre a ruptura e a desilusão. GEPAL- UEL. Apresentação em Congresso, GT1 Lutas camponesas e indígenas na América Latina Anais do V Simpósio Internacional Lutas Sociais na América Latina, 2013.

http://www.uel.br/eventos/sepech/sumarios/temas/a_revolucao_boliviana_de_1952_entr e_a ruptura e_a desilusao.pdf

WALSH, Catherine. Interculturalidad, plurinacionalidad y decolonialidad: las insurgencias políticoepistémicas de refundar el Estado. Tabula Rasa (Bogotá), 9, juliodiciembre 2008.

WOLF, Eric. “_ ”In: RIBEIRO, G.L. (Org); BIANCO, B.F. (Org). Antropologia e Poder. Contribuições de Eric Wolf. Brasília/Campinas: Edunb/Ed. Da Unicamp, 2003. 